\title{
Umbilical and uterine blood flow in pregnant sheep
}

Citation for published version (APA):

Hasaart, T. H. M. (1984). Umbilical and uterine blood flow in pregnant sheep. [Doctoral Thesis, Maastricht University]. Rijksuniversiteit Limburg. https://doi.org/10.26481/dis.19840628th

Document status and date:

Published: 01/01/1984

DOI:

$10.26481 /$ dis. 19840628 th

Document Version:

Publisher's PDF, also known as Version of record

\section{Please check the document version of this publication:}

- A submitted manuscript is the version of the article upon submission and before peer-review. There can be important differences between the submitted version and the official published version of record.

People interested in the research are advised to contact the author for the final version of the publication, or visit the DOI to the publisher's website.

- The final author version and the galley proof are versions of the publication after peer review.

- The final published version features the final layout of the paper including the volume, issue and page numbers.

Link to publication

\footnotetext{
General rights rights.

- You may freely distribute the URL identifying the publication in the public portal. please follow below link for the End User Agreement:

www.umlib.nl/taverne-license

Take down policy

If you believe that this document breaches copyright please contact us at:

repository@maastrichtuniversity.nl

providing details and we will investigate your claim.
}

Copyright and moral rights for the publications made accessible in the public portal are retained by the authors and/or other copyright owners and it is a condition of accessing publications that users recognise and abide by the legal requirements associated with these

- Users may download and print one copy of any publication from the public portal for the purpose of private study or research.

- You may not further distribute the material or use it for any profit-making activity or commercial gain

If the publication is distributed under the terms of Article $25 \mathrm{fa}$ of the Dutch Copyright Act, indicated by the "Taverne" license above, 
UMBILICAL AND UTERINE BLOOD FLOW

IN PREGNANT SHEEP 
Cover design Cy: Joezio Skrobiszewski 1984

Druk: Drukkerij Groencvell/Landgraaf 


\title{
UMBILICAL AND UTERINE BLOOD FLOW IN PREGNANT SHEEP
}

\author{
Proefschrift
}

Ter verkrijging van de graad van Doctor in de Geneeskunde aan de Rijksuniversiteit Limburg

te Maastricht, op gezag van de Rector Magnificus

Prof.Dr. H.C. Hemker, volgens besluit

van het College van Dekanen in het openbaar te verdedigen

in de Aula van de Universiteit op

donderdag 28 juni 1984

des namiddags te vier uur

door

Thomas Hubertus Maria Hasaart

geboren te Brunssum 
Promotor: Prof.Dr. J. de Haan, Rijksuniversiteit Limburg, Maastricht

Referenten:Prof.Dr. C.B. Martin jr., Katholieke Universiteit, Nijmegen Prof.Dr. F.I.M. Bonke, Rijksuniversiteit Limburg, Maastricht 
Aan mijn ouders

Aan Anne-Claire en Fleur 


\section{VOORWOORD}

Dit proefschrift kwam tot stand onder leiding van Prof.Dr. J. de Haan. Het gepresenteerde onderzoek werd uitgevoerd in het Biomedisch Centrum van de Rijksuniversiteit Limburg te Maastricht.

Bijzondere dank ben ik verschuldigd aan de inzet van promotor, opleider en wriend Jelte de Haan, die mij de beginselen wan de benodigde operatietechnieken bijbracht.

De nauwgezette beoordeling van het manuscript door de referenten Prof. Dr. C.B. Martin en Prof.Dr. F.I.M. Bonke heeft geleid tot een inhoudelijke verbetering.

Dierexperimenteel onderzoek vereist de aanwezigheid van een deskundig, zorgvuldig en enthousiast team. De medewerkers van de Centrale Proefdier Voorziening van het Biomedisch Centrum: Petra Rommers, May Bost, Ton wan den Boogaard, Frans Slangen, Hub Simons en Jet Beekman, Inger Simons en Ruud Kruger van de capaciteitsgroep Fysiologie vormen zo'n team. Jo Weyers en Wil wan Braam van de Dienst Informatieverwerking ontwierpen de computerprogramma's en wisten mijn aanvankelijk verwarde ideeën ten aanzien van de dataverwerking zodanig te integreren dat een handzaam geheel ontstond en de bediening van de uitvoerende apparatuur kinderspel werd.

Ook het opleiden tot specialist vereist teamwork en met name Henk de Koning, Gans en Frans Smits hebben in de beginperiode van mijn opleiding een zodanige basis gelegd dat het mij mogelijk werd in een later stadium veel tijd aan dit onderzoek te besteden.

Yenny Kurniawan verzorgde met Oosters geduld en precisie het merendeel der tabellen en illustraties.

De heren Sweeris, Voskamp en Houben waren behulpzaam bij het vervaardigen van enige tekeningen en foto"s.

Het manuscript werd van begin tot einde verzorgd door mijn vrouw.

Ik dank $U$ allen hartelijk voor Uw bemoeienissen.

Maastricht, april 1984 
2.2

The animal

2.3

Anesthesia

2.4

Surnical procedures

2.4 .1

Anatomy

2.4 .2

Matemal instrumentation

2.4 .3

Fetal instrumentation

2.6

Post-operative care

2.6.1 Prophylactic administration of antibiotics

2.6 .2

Flushing of the catheters

2.6 .3

Recovery period

29

2.7

Fulily equipped animal

2.8

Registration equipment

2.8.1 Electrocardlogram and cardiotachogram 32

2.8.2 Pressure registration 32

2.8.3 Arterial and venous blood flow measurement 33

2.8.4 Blood sample analysis 35

2.8.5 Display and storage of the signals 35

2.9

Signal analysis

2.9.1 Data processing 35

2.9.2 Data reduction 36

2.9.3 Artefact identification 36

2.9.4 Statistical analysis 37

2.10 Experiments 37

2.10.1 Umbilical cord occlusions 41

2.10.2 Cormon internal 111ac artery occlustons 42 


$\begin{array}{lll}2.10 .3 & \begin{array}{l}\text { Dcclusion experiments after selective } \\ \text { autonomic nervous system blockade }\end{array} & 43 \\ 2.10 .3 .1 & \begin{array}{l}\text { Parasympathetic or cholinergic blockade } \\ \text { with atropine }\end{array} & 44 \\ 2.10 .3 .2 & \text { Beta-adrenergic blockade with propranolol } & 44 \\ 2.10 .4 & \text { Alpha-adrenergic blockade with phentolamine } & 45 \\ 2.10 .5 & \text { Studies with autonomic acting agents } \\ & \text { Maternal infusions with acetylcholine, } & 45 \\ 2.10 .5 .1 & \text { Infusion protocol } & 46 \\ 2.10 .6 & \text { Fletal breathing movements, fetal } & 47 \\ & \text { intraabdominal pressure and conmon } & 49\end{array}$

CHAPTER III COMMON INTERNAL IIIAC ARTERY OCCLUSIONS AND UMBILICAL VENOUS BLOOD FLOW

$3.1 \quad$ Introduction 51

$3.2 \quad$ Literature 52

3.3 Summary 56

3.4 Materials and methods 58

$3.5 \quad$ Results 58

3.5.1 Changes in fetal arterlal pH and blood gases 58

3.5.2 Intact autonomic nervous system 59

3.5.3 Selective blockade of a part of the autonomic nervous system 73

3.5.3.1 Cholinergic blockade with atroptne 74

3.5.3.2 Alpha-adrenergic blockade with phentolamine 80

3.5.3.3 Beta-adrenergic blockade with propranolol 88

3.6 Instantaneous umbilical venous blood

flow patterns during occlusions of the

matemal comon internal 111ac artery 94

$3.7 \quad$ Discussion 96

3.7.1 Intact autonomic nervous system 96

3.7.2 Cholinerglc blockade with atropine 99

3.7.3 Alpha-adrenergic blockade w1th phentolamine 100 
3.7.4 Beta-adrenergic blockade with propranolol

3.7.5 Changes in the Instantaneous umbllical venous blood flow during occlusions of the comon internal 11iac artery

CHAPTER IV UMBILICAL CORD OCCLUSIONS AND UMBILICAL VENOUS AND MATERNAL, PELVIC BLOOD FLOW

$\begin{array}{ll}4.1 & \text { Introduction } \\ 4.2 & \text { Mechanisms of the vartable deceleration } \\ 4.3 & \text { Umbilical venous blood flow and cord compression } \\ 4.4 & \text { Pelvio arterial blood flow and cord compression } \\ 4.5 & \text { Materials and methods } \\ 4.6 & \text { Mesults } \\ 4.6 .1 & \text { Matemal internal } 1 \text { llac artery blood flow during }\end{array}$ umbilical cord occlusion

4.6.2 Matemal median uterine artery blood flow during umbilical cord occlusion

4.6.3 Simultaneous measurement of maternal internal illac artery and median uterine artery blood fllow during umbilical cord occlusion Instantaneous umbilical venous blood flow during occlusion of the umbilical cord

4.7.1 Intact antonomic nervous system

4.7.2 Selective blockade of the cholinerglc, alpha-adrenergic and beta-adrenergic part of the autonomlc nervous system

4.8.1 Blood flow in the matemal internal 1liac and median uterine artery during umbillical cord compresston

4.8.2 Instantaneous umbilical venous blood flow during occlusion of the umbilical cord in fetuses with intact autonomic nervous system

4.8.3 Instantaneous umblilical venous blood fllow during occlusion of the umbilical cord after 
selective blockade of the cholinergic, alpha-adrenergic and beta-adrenergic part of the autonomic nervous system

CHAPTER V EFFECTS OF AGONISTS AND ANTAGONISTS OF THE AUTONOMIC NERVOUS SYSTWM ON FEIAL HEAFT RATE, ARTERIAL BLDOD PRESSURE AND THE BLOOD FLOW IN THE COMMON OMBILICAL, VEIN

5.1

Introduction

Materlals and methods

Results

The effect of agonists and antagonists of the autonomic nervous system on fetal heart rate, arterial blood pressure and mean umbilical venous blood flow

5.3.1.1 Cholinergic blockade with atropine Alpha-adrenergic blockade with phentolamine Beta-adrenergic blockade with propranolol Cholinergic stimulation with acetylcholine Alpha-adrenergic stimulation with norepinephrine Beta-adrenergic stimulation with fenoterol

5.3 .2

\section{$5 \cdot 3 \cdot 2 \cdot 1$} The effects of agonists and antagonists of the autonomic nervous system on the instantaneous blood flow pattem in the cormon umblilical veln

5.4.1 Effect of autonomlc antagonists on heart rate, blood pressure and mean umbllical venous blood flow 
5.4.1.2 Alpha-adrenergic blockade with phentolamine 148

5.4.1.3 Beta-adrenerglc blockade with propranolol 149

5.4.2 Effect of agonists of the autonomic nervous

systen on heart rate, blood pressure and mean

umblilical venous blood flow 151

5.4.2.1 Cholinergic stimulation with acetylcholine 151

5.4.2.2 Alpha-adrenergic stimulation with norepinephrine 151

5.4.2.3 Beta-adrenergic stimulation with fenoterol 153

5.4.3 Efrect of agonists and antagonists of the

autonomic nervous system on the instantaneous

blood flow pattern in the common umbilical vein

153

CHAPTER VI EFFECIS OF FENOTEROL, NOREPTNEPHRINE AND ACETYLCHOLINE INFUSION TO THE ENE ON MATWRNAL PELVIC ARTERIAL AND FETAL UMBILICAL VENOUS BLDOD FILOW

\begin{tabular}{|c|c|}
\hline 6.1 & Introduction \\
\hline 6.2 & Nomenclature of the arterial pelvic vasculature \\
\hline 6.3 & $\begin{array}{l}\text { Blood flow responses of the maternal pelvic } \\
\text { vascular bed to vasoactive stimuli }\end{array}$ \\
\hline 6.3 .1 & Alpha-adrenerg tc agents \\
\hline 6.3 .2 & Beta-adrenergic agents \\
\hline 6.3 .3 & Chollnergic agents \\
\hline 6.4 & Innervation of the uterine vascular bed \\
\hline 6.5 & $\begin{array}{l}\text { Effects of maternal Infusion with } \\
\text { alpha-adrenergic, beta-adrenergle and } \\
\text { cholinergic agents upon umblilcal blood flow }\end{array}$ \\
\hline 6.5 .1 & Inf"luences of alpha-adrenergic agents \\
\hline 6.5 .2 & Inf'luences of beta-adrenergic agents \\
\hline 6.5 .3 & Influence of acetylcholine \\
\hline 6.6 & Alm of the Investigation \\
\hline 6.7 & Matertals and methods \\
\hline 6.8 & Results \\
\hline 6.8 .1 & $\begin{array}{l}\text { Effect of continuous administration of } \\
\text { fenoterol to the ewe on the maternal and }\end{array}$ \\
\hline
\end{tabular}


6.8.2 Effect of continuous irfusion of acetylcholine to the ewe on the maternal and fetal parameters

6.8.3 Effect of continuous infusion of norepinepline to the ewe on the matemal and fetal parameters

6.9.1 Effect of contimus administration of fenoterol to the ewe on the maternal and fetal parameters

6.9.2 Effect of contimuous adninistration of acetylcholine to the ewe on the matemal and fetal parameters

6.9.3 Effect of continuous administration of norepinephrine on the maternal and fetal parameters 179

CHAPTER VI FETAL BREATHING MOVEMENTS AND UMBILICAL VENOUS BLOOD FLOW

7.2 Fetal breathing and chest wall movements

Cardlovascular effects of fetal breathing movements

Umbilical blood flow and fetal breathing movementis

Aim of the study

7.7.1 Rapld irregular breathing and Instantaneous umbilical venous blood flow

7.7.2 Fetal hilccups and instantaneous umb11ical venous blood flow

7.7.3 Expiratory efforts and instantaneous umb1ilcal venous blood flow

7.7.4 Fetal intraabdominal and intratracheal pressure during fetal respiratory movements

7.7.5 Fetal gasping and instantaneous umbilical venous 


\section{LIST OF ABBREVIATIONS}

\begin{tabular}{|c|c|}
\hline a. & artery \\
\hline $\mathrm{BE}$ & base excess \\
\hline bpm & beats per minute \\
\hline C & control value \\
\hline $\mathrm{cm}$ & centimeter \\
\hline $\mathrm{E}$ & value measured at the end of the occlusion pertod \\
\hline ECG & electrocardiogram \\
\hline EFW & estimated fetal weight \\
\hline FrBP & fetal arterial blood pressure \\
\hline FECG & fetal electrocardiogram \\
\hline FHR & fetal heart rate \\
\hline FIAP & fetal intraabdominal pressure \\
\hline Fig. & figure \\
\hline & gamma $(1=1$ microgram $)$ \\
\hline g. & gram \\
\hline $\mathrm{hr}$ & hour \\
\hline $\mathrm{Hz}$ & Herz \\
\hline IIJ & International unit \\
\hline IUFD & intrauterlne fetal death \\
\hline IUP & intrauterine pressure \\
\hline $\mathrm{Kg}$ & k1logram \\
\hline $\mathrm{kPa}$ & kilo Pascal $(1 \mathrm{kPa}=7.5 \mathrm{~mm} \mathrm{Hg})$ \\
\hline 1. & I1ter \\
\hline M & mean \\
\hline mifq & milliequivalent \\
\hline$m g$ & milligram \\
\hline $\min$ & minute \\
\hline $\mathrm{ml}$ & milliliter \\
\hline $\mathrm{mm}$ & millimeter \\
\hline $\mathrm{mm} \mathrm{Hg}$ & millimeters of mercury \\
\hline msec & $\mathrm{mil11 \text {second }}$ \\
\hline$n$ & number \\
\hline anim. & number of animals \\
\hline
\end{tabular}




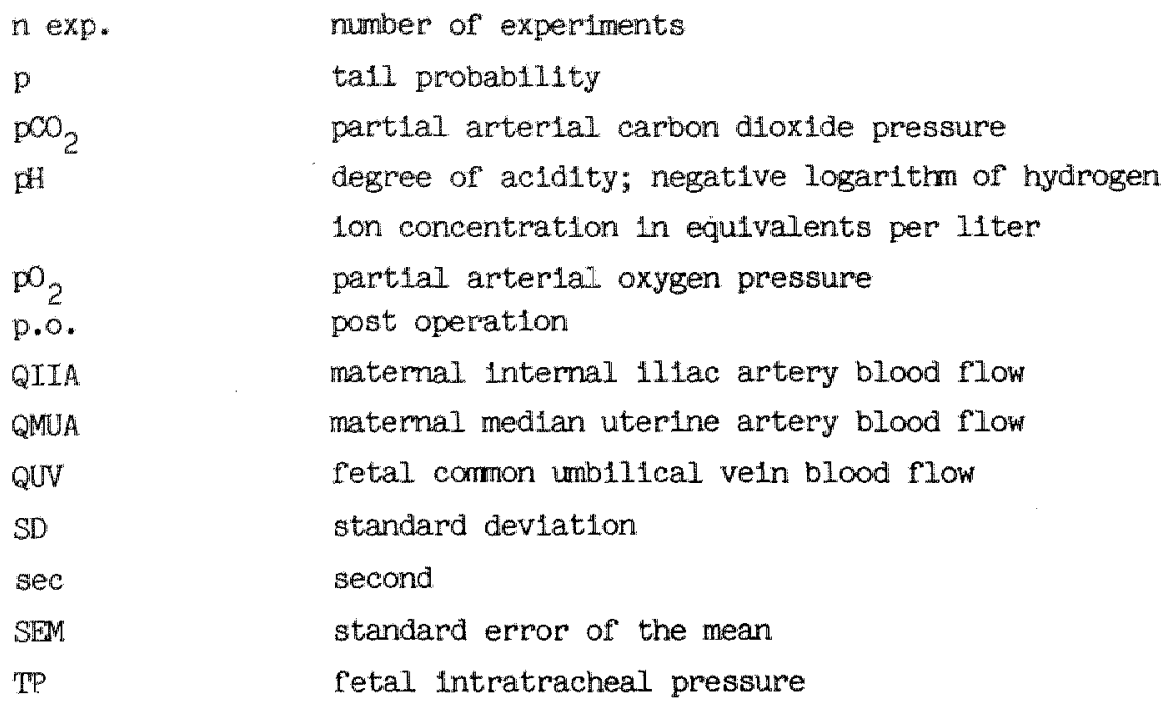




\section{CHAPTER I}

\section{GENERAL INIRODUCTION}

The nomal development of the retus during intrauterine Itfe, 1 ts growth and wellbeing as its capac1ty to tolerate the stress of labor and delivery depend to a great extent upon the integrity of the fetoplacental circulation, a subject of study during centuries. The present accumulated knowledge on fetal physlology in general and fetal circulation in particular, is malnly the product of work and thought in the twentieth century. The foundation however was laid In the discoverles of the Anclents and in the seventeenth century, when Will lam Harvey flrst described the clrculation of the adult as well as that of the fetus in his Exercitatio anatomica de motu cordls et sargulnis (1628). The unique anatomical features of the fetus had been described long before Harvey's publications. Galenus flrst described the foramen ovale and the ductus arterlosus in 1525, while vesaltus apparently was the first author who mentioned the ductus venosus in a work published posthumously in 1564 .

The slow flowering process in the unraveling of the fetal physlology unt11 modern tImes was amongst others due to the defective techntcal facilitles while the methods of comunlcation between Investlgators and the spread of knowledge were only a firaction of present-day possibll1ties.

For example, more than two hundred years elapsed between raising of the question of fetal resplration in utero by Willam Harvey in 1651 in hls Exercitationes de Generatione Animallum and the final answer by paul Zwelfel, a Swiss obstetrician in 1876. Zwelfel"s denonstration, that the fetus resples via the placenta is one of the landmarks in the development of our understanding of $11 \mathrm{fe}$ in utero. His findings were conf1rmed by zuntz in 1877 . 
The exceedingly rapld developments of the past fifty years are related directly to the use of a wide range of technologies.

In the same time several animal models in different species as sheep, subhuman primates, goats, guinea-p1gs and sows were developed for the study of fetomatemal physlology, from which animal models the chronic pregnant sheep preparation is the one mostly used in perinatal research. The combination of the pregnant sheep model in a chronic way and the avallable technology has yielded enormous information on fetomatemal physlology with a considerable impact on the modem management of pregnancy and especially labor.

The introduction of simultaneous monftoring of the fetal heart rate and uterine activity by Hon (1960), Hamacher (1962) and Caldeyro-Barcla et al (1963) has led to the recognition of various fetal heart rate patterns during pregnancy and labor and fetal hypoxemLa can now be detected before fetal condition deteriorates.

Studies in the chronic sheep preparation varying from causing maternal and fetal hypoxemia to intermuption of fetal and matemal placental c1rculation have revealed several of the mechansisms by which the fetus reacts to acute and chronic stress. The reflections of acute and chronic stress are found in the fetal heart rate patterns, which are nowadays a safe and reliable guldeline for the judgement of fetal well being in utero.

Together with the introduction of fetal scalp blood sampling during parturtion (Saling 1962), which makes it possible to deternine the fetal acld-base balance, fetal heart rate monitoring is an indispensable tool in modem obstetrics. Fetal acldemla and hypoxemta both in pregnancy and labor can now be recognized and assessed and management of labor can be directed in those cases in such a way that irreversible damage to the fetus caused by hypoxia is avolded.

Continuous measurements of $\mathrm{pO}_{2}$ wlth scalp electrodes are performed both In the human and In animal studies (Huch et al 1977, O'Connor and Hytten 1979, Aarnoudse 1980), but they are not directly applicable in routine obstetrical care, at least in their present technical state, whereas it is questionable whether they give useful additional inforgnation next to fetal heart rate monitoring.

The technical improvements of ultrasonography opened up new fields of 
Investigation as fetal behaviour in utero and the deteotion of congenital anonalies.

Simultaneous reglstration of fetal heart rate and fetal movements as a routine measurement is not easy to perform, but may add valuable infomation on fetal well-beling in spectal cases.

Ultrasonographic observations of fetal body and breathing movements in. utero can yleld in the same way valuable information, among other things on congenital malformations.

Recent studies were directed to the relations between heart rate, breathing movements, fetal behavorial states and brain activity (Dawes et al 1972, Wheeler et al 1980, van der Wildt 1982).

Fetal and matemal placental blood flows have been under study in anlmal models for several decades with different methods of measurement.

Desplte the increased knowledge on the regulation of the placentral blood flows by the development of the chronic fetal sheep model in perinatal research, st11l relatively less is known about flow regulation to and from the placenta than about the regulation of flow in any other organ. Due to technical and ethical problems involved only scarce data on placental blood flow in the human are avallable.

Assal1 et al (1960) measured uterine blood flow by means of" electromagnet1c flow transducers in the first two trimesters in the human. Washout methods using $133 \mathrm{Xe}$ in the human estimate the clearance from myometrium (Jansson 1969), but do not glve absolute figures. Recently a noninvasive method of flow measurement is used in the human conslsting of a combination of pulsed Doppler ultrasound technique for flow velocity measurements and real time B-scan ultrasonography for localization and assessment of the dianeter of the bloodvessels to be measured. Although this technlque has several technical and methodologlcal shortcomings, which make this method not yet avallable for routine hospital practice, the preliminary results are promising for the study of fetal hemodynamics in the near future (E1k-Nes et al. 1980, Elk-Nes et al 1982, Joupplla et al 1983).

The earilest measurements of uterine blood flow were done by Barcroft et al (1933), who collected the uterine venous outflow of the rabblt over longer" perlods of time. This method was replaced by the discovery 
of Kety and Schmidt In 1948 that an estimate of t1ssue blood mow could be obtained in man using a diffusible inert gas such as nitrous oxide. Assall et al (1953) measured with thls method uterine blood flow in the human, later they compared it with the results obtalned by means of electromagnetic flow transducers (Assal1 et al 1960).

4-amino-antipyrene instead of nitrous oxide was used by Huckabee et al In 1961 to measure the uterine blood flow in goats on the basis of the diffusion-equilibrium technlque. Electromagnetic flowtransducers for the measurement of uterine blood flow are avallable since the late fifties. Kirschbaum et al (1967) demonstrated their usefulness in uter'Ine flow measurement in pregnant sheep.

RadLoactive microspheres, injected into the arterial circuiation will be distrlbuted in accordance with the arterial blood flow, if they are well mixed with the blood and if they are too large to pass through the precaplilary arterloles. Thls technique was first used for uterine blood flow measurement in sheep by Makowskl et al in 1968 after a modifleation of the technique by Rudolph and Heymann in 1967.

All the mentloned techniques have thelr disadvantages and limitations. The diffusion-equilibrium technique glves flow data in $\mathrm{ml} / \mathrm{min}$ per $\mathrm{kg}$ of uterus and Intrauterine tissue. The precise intrauterine tissues, in casu fetus and placenta, and the possible involvement of amnlotic fluid however are not adequately defined with this method.

The diffusion-equilibrium technique gives a constant value for the blood flow to the uterus per unit welght from 90 days gestation onwards to term, but the absolute flow expressed in $\mathrm{ml} / \mathrm{min}$ rises during the course of pregnancy due to the increasing mass of uterus and intrauter-ne tissues.

Electronagnetic flow transducers and the radioactive microsphere technlque are now the two most used methods of flow determination, al though each method has 1 ts specific problems which make them not sultable for every sort of experiment. The positioning of electromagnetic flow transducers around maternal and fetal vessels for chronic use requires extensive surgery. The flow transducer around the vessel may in itself produce artifacts by compressing or kinking the vessel, while the vessel can react upon the stripping of its perivascular attachments by vasoconstriction. Movements of the flow 
transducen around the vessel can cause artifacts and it takes at least several days before the flowprobe is attached to the vessel wail by adhestons and a good steady contact between the Inner surface of the flow transducer and the vessel wall 1 s achleved. Other problems Involve the callbration of the flow transducer and their influence upon each other if placed in each others proximity, which w111 be brlefly discussed later on (paragraph 2.8.3).

The exact total flow to the uterus can not be assessed with electromagnetic flow transducers because the uterus has several arterlal Inputs and vessel anastomoses which cannot be measured all together, so flow measurements in the uterine artery reflect only part of total blood flow to the utems. On the other hand, if one measures the blood flow in one of the major vessels from which the uterine blood supply arises, then flow measurement not only comprises the blood flow to the uterus but also part of the flow to other adjacent structures. And finaliy no differentiation can be made between placental blood flow and uterine muscle blood flow.

The radioactive microsphere method is an accurate way to measure blood flow and has the advantage of belng able to measure the total uterlne blood flow and 1ts distribution over the various parts of the uterus and its contents. It is however also a technically cumbersome method and in general only one observation can be made in one animal unless microspheres with different radioactive labels are used. Furthemore this technique glves only an instantaneous flow measurement and continuous flow changes cannot be registrated.

When comparing the results of seweral techniques, one should always bear in mind the specific problems related to the method used. Another continuing problem in the evaluation of the literature on the regulation of placental blood flow is the effect of the condition of the animal durlng chronlo experiments and the lnfluence of anesthesla and surgical Intervention in acute experiments upon the placental blood flow and its response to vasoactive agents.

The fetal slde of the placental blood flow can be studled relatively easler since the whole of umbllical placental blood flow is contalned in the umblitcal cord. Cohnstein and Zuntz (1884) were the first who 
studied umbl11cal blood flow in the Ilving lamb fetuses. Studies in living fetuses in this perlod were troubled by technical 11mitations and rapld deterloration of the preparations. Technical developments and the use of anesthesla gave way to more sophlsticated research on fetal hemodynamlos.

Bercroft (1946) measured for the first time the course of blood through the principal vessels of the fetal lamb by rapld serial radioanglography. Cooper and Greenfleld (1949) used a plethysmograph to measure the umbllical blood llow in the lamb, whlle retaining the Integrity of the umblilcal clrculation. After imersion of the fetal lamb in a wam physlological saline bath, the umblilcal veins were occluded and the rate of decrease of fetal volume was taken to represent unbllical blood flow, which was reported to amount $500 \mathrm{ml} / \mathrm{min}$ near term. Greenfleld et al (1951) even used this method successfully In the human for umbilical blood flow measurement.

The application of electromagnetic induction to the measurement of blood flow in vivo was used by Dawes and Mott (1964) who Inserted an electromagnetic Mowprobe in a short extemal circult between the cut ends of the abdominal umbllical veln. The observations were made after delivery of the near term fetal lamb by caesarean section with an Intect umbllical circulation. Umblilical venous blood flow was reported to be $170 \mathrm{mI} / \mathrm{min}$ per $\mathrm{kg}$ of fetus. Kirschbaum et al (1967) found corroborative results in a similar experiment. They reported mean umbllical blood flow to be $138 \mathrm{ml} / \mathrm{min}$ per $\mathrm{kg}$ of fetus in the near term fetal lamb.

Wh the use of the Flck-princlple and urea as test substance, Meschia et al (1966) found umblilcal blood flow values of $233 \mathrm{ml} / \mathrm{min}$ per $\mathrm{kg}$ of fetus. Rudolph and Heymann (1967) proved the walldity of this method with the simultaneous use of electronagnetic flow transducers. The difference between the resultis obtalned by Dawes and Mott (1964) and Kirgchbaum et al (1967) compared to the higher values reported by Meschla et al (1966) and Rudolph and Heymann (1967) (220 ml/m/m/Kg of fetus) is due to the fact that exteriorlation of the fetus by delivery decreased the umbllical blood flow (Heymann and Rudolph 1967). Wth the introduction of radioactive microspheres for flow measurenents and the technical improvements of electromagnetic flow transducers, 
more rellable and elegant methods are now avallable for measuring the umbllical blood flow. Makowskl et al (1968) applled the radloactive microsphere method also to the measurament of the umb111cal blood Plows, as they did for uterine flow measurenent. Since then reports have been published on umbilical and fetal organ blood flow under various conditions (Peeter's 1978, Edelstone et al 1980b, Reuss and Rudolph 1980, Bottil et al 1982).

The microsphere method employs catheters in fetal arterles and velins which in general can be done with simple surgical techniques without jeopardizing the fetus too much. However only relatively few deteminations can be made in one animal and the processing methods afterwards are time consuning. The microsphere method might be the method of cholce if one wants to separate the umbllical blood flow in that to the placenta and the part to the mombranes and 1 t 1 s especlaily applicable for studies of umbilical fllow distribution to different organs. The improvement of the rellablilty of electronegnetilic flow transducers and their reduction in slze have made them highly favorable In recent years for chronic measumements of unbllical blood flow in animal preparations. Oakes et al (1976a) have described a technlque for implanting electromagnetic flow transducers around the comnon Intraabdominal umbllical veln, while Beman et al (1975) developed a similar technique whereby the probe is placed around the comon umbilical artery via a retroperitoneal approach. Both methods provide a direct and continuous measurement of umblilcal blood flow in a chronlc preparation over longer perlods but they do not separate the flow into 1ts components. Impilantation of eleatronagnet1c flow transduoers in the chronic experimentp on the common umbilical veln op artery is not easily to perform and requllines extenslve fetal surgery with a conconitent considerable fetal loss even in expertenced hands, while fetal recovery from surgery requires at least three days (Assal1 et al 1974, de Haan et al 1975, De Muylder et al 1983).

Ideally, the measurement of blood flow in vivo would be done noninvasively; that is to say, without any surglcal intervention whatever. The Doppler flow systems might possibly fulfil some of these Whishes for the flidd of perinatal research in the near future, as they already do in the human for the examination of peripheral arterles 
(Baker et al 1974, Bod1ly et al 1981, Bruins Slot 1981, Breslau 1982). The placental elrculation is vital to the fetus and 1ts well functioning a conditio sine qua non for normal fetal development. Factors that influence fetal and/or matemal placental circulation as for example various drugs, cord compression and obstruction of uterine circulation can have a detrimental effect on the fetus. The regulation of the placental blood llows encompasses several sections including the neural regulation which has been reviewed by Bell (1972), secondly, the mechanical regulation with the problen of sluice flow and thirdly, the chemical factors that influence fetal and matemal placental flows. These chemical factors are not well defined and they comprise various substances such as anglotensin, renin, catecholamines, prostaglandins and sterolds (Rankin and McLaughlin 1979).

The present study was undertaken to investigate some aspects of matermal pelvic and fetal umbilical blood flow and their possible Influences upon each other.

The maternal part deals with reactions of the blood flow in the pelvic arterial bed, in casu the internal lliac artery and median uterine artery, to vasoactive stimul1 by the cholinergic and adrenergic drugs acetylcholine, noreptnephrine and fenoterol (=Partusisten ${ }^{R}$ ) and their Influence on fetal hemodymamics and acid-base balance. Adrenergic receptor activity is of particular interest in pregnancy because of its influence both on the uterine circulation and uterine tone and contractility. Beta-sympathicomimet1c drugs as for example fenoterol are widely used in obstetrics for the treatment of premature labor and Intrapartum fetal distress and by some even for the treatment of intrauterine growth retardation. Alpha-adrenergic activity can be caused by catecholamines and related vasoactive substances and it is a potential hazardous side effect of some drugs with the central nervous system as the1r target organ.

Paln and fear during labor increase the level of clrculating catecholanines whlch can hamper uterine blood flow.

The effects of tocolytic beta-sympathicomimetic drugs on uterine and umblilical blood flow were studied in non-laboring pregnant sheep (Brennan et al 1977, Ehrenkranz et al 1976, 1977a, 1977b, Chez et al 
1978, Dakes et al 1978b, Nuwayhid et all 1978, 1980). They obtained data from these studies on the reactions of the uterine vascular bed upon intravenous administration of beta-adrenerglc drugs to the ewe are not one at all 1dentical. In some studies increases in uterine blood flow were reported while others showed no changes or decreases in flow after beta-adrenergic drug infusion. Part of these differences might be explained by the fact that different beta-sympathiconimetic drugs are compared, but more important seems the site of flow measurement in the pelvic vascular bed. Some authors used the median uterine artery for flow measurements while others recorded blood flow in the main uterine or common internal 11 lac artery. These vessels however do not have to react in the same way and/or degree upon vasoactive stimuli, as was recently pointed out by the group of Assali. The different reactions of the various vessels in the pelvic arterial bed to vasoactive stimuil might be explained by different autonomic innervation of the vessels (Assali et al 1981, Erkkola et al 1981, Tabsh et al 1981). Fetal umblilical flow elther showed no change or an increase during matemal infusion with beta-adrenergic agents (Brennan et al 1977, Ehrenkranz et al 1976, 1977a, 1977b, Chez et al 1978, Oakes et al 1976b).

General consensus exists on the vasoconstrictive effect of alpha-adrenergic agents on the median uterine artery and on the common Internal iliac artery with a more marked effect on the median uterine artery (Greiss 1963, Grelss and Pick 1964, Tabsh et al 1981, Assall et al 1981). Fetal umbilical flow was not affected by maternal norepinephrine Infusion in two studies (Chez et al 1978, Wilkening et al 1982). The effect of acetylcholine upon the pelvic vascular bed does not seem quantitively to be the same in the varlous vessels (Grelss et al $1967 \mathrm{c}$, Erkkola et al 1981 ).

The possible influence of maternal acetylcholine infusion upon fetal umbillcal blood flow is not known.

The fetal part of this investigation deals with the effects of subacute fetal distress caused by compression of the umbilitcal cord and by occlusion of the uterine blood supply on umbilical venous blood flow and in the case of umbilical cord compression also with its possible effects on the maternal uterine blood flow.

Subacute fetal distress can be mimlcked by obstruction of the uterine 
circulation. Subacute reduction of uterine blood flow can thus, as is generally accepted, Imitate the clinical concept of subacute uteroplacental insuff Lclency. The hemodynamic sequelae as the changes in heart rate (late decelerations"), the rise in blood pressure and the responsible reflex nechanlims have extensively been studied in sheep (Evers 1978, Martin et al 1979, de Haan et al 1979, Itskov1tz et al 1982a, Kunzel et al 1983). Scarce data however are avallable on the effectis of uterine blood flow obstruction on umbllical blood flow.

Beman et al (1976) reported some data on umbllical arterial blood flow In a study of the relationship between pressure and flow in the umbllical and uterine circulations of the sheep. Data on arterial umblifical. blood flow during obstruction of the matemal aorta in the hypoxlc fetus were recentily published by Harmis et al (1982), while Parer et al (1980) gave data from the same sort of experinents in normoxemle fetuses. In these studies umbllical arterial blood flow was measurea. It is expected that umbllical venous blood flow would show the same reaction patterns as the arterial side of the clrculation. Knowledge of the reactions of the umbilical venous flow to acute uteroplacental insufficlency by uterine blood flow obstruction is not merely of physiological interest, but might be essential in the near Puture with the further development of the Doppler-flowsystems for measurement in pregnant women.

Translent compresslon of the umblilcal cord with the characteristic reactions of fetal heart rate deceleration and blood pressure rise is a common occurrence in clinlcal obstetrics, easily recognizable by fetal heart rate monltorlng. The fetal responses to hypoxemla caused by umblilcal cord occluston have been well documented 1 in several studies (de Haan et al 1976, Evers 1978, Towell et al 1978).

Wuch less is lenown about the effects of cord compression on the maternal placental circulation.

In 1973 Power and Longo proposed a theory about the maternal vascular pressure effects on fetal circulation, which they calied "slulce fllow In piacenta". "This theory is based on the assumption that the uterine vascular system surrounds the umb11ical clrculation in the placenta and generates a placental tissue pressure which affects umbilical blood flow by the waterfall mechanism. 
Berman et al (1976) however showed in a study on pressure-flow relationships in the uteme and umblical circulations that this waterfall-mechanlsm is absent in the placental circulation of the sheep. Part of their study was the obstruction of umbllical venous flow by inflating a balloon in the common umbilical veln, while concomitantly uterine flow was measured with an electromagnetlic flow transiucer.

They found no change in uterine blood flow during obstruction of umbillcal venous flow. The accomplished umblifical flow obstruction was however only partial and of a very short duration. Moreover their definition of uterine blood flow was the flow in the comon uterine artery, (=comon internal illac or comon hypogastric artery), the terminal branch of the abdominal aorta, that also provides extrauterine structures with blood, and is not directly adjacent to the uterus. Cottle et al (1982) reported a depression of uterlne bilood flow as measured in the median uterine artery in response to longer lasting ( 4 minutes) cord compression in sheep.

The fetuses of all so far studied manmals including the human make periodic thoracic and dlaphragmatic movements during intrauterine $11 \mathrm{fe}$, which are called fetal breathing movements.

The first animal observations on fetal breathing movements were done by Béclard (1815) in dogs and cats with opened uterus, but Intact membranes. Anlfeld, a German gynecologist, described in 1888 rhythmical movements of" the fetus seen on the intact maternal abdominal wall in the human, which he considered fetal breathing movenents.

Breathing movements in fetal slieep under spinal anesthesla were observed by Barcroft in 1946. In the last two decades the 1nfluences of hypoxemia, hypoxia, hyperoxia, hypocapnia, hypercapnia, asfyxia, glucose, prostaglandins and thelr synthetase lnhlbltors, matemal smoking and many other 1tems on fetal breathing movements have been Investigated.

Rurak and Gruber (1983) described an increased oxygen consumption assoclated with breating activity in fetal lambs, together with an Increase in umbll1cal blood flow during fetal breathing movements. Umblilcal blood flow was measured with an electromagnetic flow 
tranisducer around the comnon umb1lical artery in acute experiments and by means of the steady state diffusion technique in chronic experiments.

Rudolph (1976) reported the negative effect of a rise in intrathoracic pressure on urabllical arterlal blood flow.

Chiba et al (1981) published observations on the relation between flow velocity measured with pulsed Doppler flow transducers in the human umbilical vein and fetal breathing movements. 
The ain of this study was to investlgate some aspects of the matemal pelvic and fetal unblilical circulation.

The following speciflc questions were studied:

1. What are the effects of late decelerations in the fetal hearto rate pattern produced by uterlne low obstruction on unbl11cal venous blood flow? (chapter 3)

2. What are the effects of cord compression on the instantaneous fetal umblilcal blood flow patterm? (chapter 4)

3. Does cord compression influences maternal uterine blood Ilow? (chapter 4)

4. What are the effects of agonists and antagonists of the autonomic nervous system on umblilcal venous blood fllow? (chapter. 5)

5. What are the effects of matemal infusion with cholinergle and alpha-and beta-adrenergic agentis on the blood flow ln the matemal internal 111 ac and median uterine artery? (chapter 6)

6. What are the effects of matemal infusions with cholinergic and alpha-and beta-adrenergic agents on fetal umbilical blood f'low ? (chapter 6)

7. What are the influences of intermittently accurring retal. breathing movements on umb1l1cal venous blood fllow? (chapter 7)

8. How does fetal gasping, occurring during acute fetal hypoxemia affects umblilcal venous flow ? (chapter 7) 

CHAPTER II

\section{MATERTALS AND MEIHODS}

\subsection{Introduction}

Pregnant sheep have been widely used in fetal physiological research and considerable information on fetal and maternal cardiovascular function is avallable at the moment.

After the first description of the fetal circulation by W1111an Harvey In 1628, further hypotheses of the clrculation of blood in the fetus mere for almost 300 years after Harvey's publication solely based on anatomic observations.

Physlologleal studies in living fetuses were first reported by Cohnstein and Zuntz in 1884, who measured umb1lical arterial pressure in exposed lamb fetuses and by Pohiman in 1907 and 1909, who studied fetal circulation through the heart in pig fetuses.

After that, Barcroft in the mid-thirties and forties made his classic abservations on the umbillcal placental circulation in fetal sheep in an acute manmer while the ewe was under general or spinal anesthesia and the fetus mostly exteriorized from the utem (Barcroft 1946).

Dawes and coworkers in Oxford, England (1968a) and Assall and colleagues in Los Angeles, U.S.A. (1965, 1974) reported extensive studies on fetal clrculation in exteriorized fetal lambs.

Although these acute studles have ylelded enomous Information with respect to fetal physlology, one has become aware during the last 15-20 years of the disturbing effects of maternal anesthesia, fetal. exteriorization and menlpulation on fetal cardiovascular function (Heymann and Rudolph 1967) and other regulatory mechan1sms. Thls has led in different centers to the development of chronlc animal preparations with the fetus in utero, which allow fetal studies without 
the influence of anesthetic agents.

Several manmallan species (sheep, goat, primate, plg) have been used in intact animal preparations. Since the marmalian fetus is surrounded by amilotic fluid within the membranes, which are covered by the uterine wall, access to the fetus can only by obtalned by incising the matemal abdominal Wall, the uterine muscular wall and the membranes.

These procedures may to an unknown extent interfere with uterine activity and fetal physiology.

In contrast to primates, for instance, which have a thick muscular uterine wall, sheep and goats possess a thin utertne musculature which on inclsion only shows local contractions which do not interfere usually in such an extent with uterine circulation, that the fetus becones hypoxemic or even asphyxiated.

Another advantage of the sheep uterus in relation to surglcal procedures is the fact that the sheep placenta is polycotyledonous, which makes it possible to inclse the uterine wall in an area free of placental attachments. Furthemore there is little tendency to separation of the placental attachment after surgery and postoperative abortion due to placental abruption or circulatory disturbance is very low in sheep. The circulation of the fetal lamb has the same three shunts that also exist in the human fetus: foramen ovale, ductus arterlosus Botall1, and ductus venosus Arantil.

Major anatomical differences consist of the number of umbllical velns which are two in fetal sheep. Furthermore the sheep placenta is of the eplthellochorlal type in contrist to the human hemochorlal placenta. The uterus of the sheep is an utems bicomis unicollis with a thinner muscular wall than the uterus of primates and the human. The non pregnant uterine horn is much smaller than the pregnant horn and is Pliled with amnlotic fluid. The Inner surface of the pregnant horn is covered by the chorlonic membrane which encompasses the amnlotic sac, containing the fetus and the allantolc sac which extends from the urachus in the umblilcal cord and which f1lls part of the uterine cavity. The blood supply to the uterus in sheep is also different from the sltuation in the human as will be pointed out later on (paragraph 2.4.1). 


\subsection{The animal}

All experiments were carrled out in primigravid ewes of the Dutch sheep (Texel breed). Flrst pregnancies in ewes are mostly slngleton pregnancles which was in all the experimental animals but one (no 8315 , twins) the case.

The pregnant ewes were obtained from the Praktilkschool at Horst.

The conception dates of 11 of the animals used in this study was well known, but in 4 instances however no exact date was knomm. In these cases duration of pregnancy was estimated during operation by using the crlteria of Naaktgeboren and Stegeman (1969) for the fetuses of Dutch sheep of the Texel breed. At least three days before surgery the animals were transported to the animal laboratory, where they stayed in a small moblle cart in order to get used to their new surroundings.

Food was withheld twenty-four hours prlor to operation and water twelve hours preceding operation.

After the operation the ewe was allowed to recover for at least 72 hours before experiments were perfomed. Inmediately after operation the ewe got food and water ad liblturn. During the recovery and experimentation period maternal rectal temperature was controlled dally as was fetal arterlal blood gas balance.

During the 72 hours recovery perlod only steady state reglistrations of fetal and maternal parameters were recorded without any experimentation.

The period of time between operation and the end of each series of experiments ranged between 5 and 35 days.

The experiment ended when the fetus died in utero or was stiliborn, and also in those cases in whlch the ewe developed labour whlch ended elther spontaneously vaginally or by caesarean section.

Seven fetuses were born allwe elther vaginally or by caesarean sectlon. Al1 the fetal instrumentation was removed after birth.

The matemal transducers and occluders were removed at caesarean section or by relaparotony after birth of the lamb. 


\subsection{Anesthesia}

Al] surgical procedures were perfomed during general anesthesla. The anesthetic procedures were started by $0.5 \mathrm{ml}$ xylazine (Rompun ${ }^{\mathrm{R}}$ ) intravenously and $0.03 \mathrm{mg} / \mathrm{kg}$ body welght scopolamine hydrobronidum $0.025 \%$ intramuscularly. Induction was performed with pentobarbital (Narcovet ${ }^{R}$ ), $15 \mathrm{mg} / \mathrm{kg}$ intravenously and the ewe was then intubated, while she was lyling on her back on the operation table.

The tube was connected to an artificlal resplrator (type Drager Pulmomat 19.1) and general anesthesia was continued with halothane in a concentration of 3-5\% initialiy in a 2:1 mixture of nitrous oxide $\left(\mathrm{N}_{2} \mathrm{O}\right)$ and oxygen. The halothane concentration was reduced during the further procedure from $5 \%$ to $1 \%-1.5 \%$.

The ewe was monttored by E.C.G. registration (Schwarzer C3600, Monftor Knott SG 4100) and by $\mathrm{CO}_{2}$ measurements in a capnograph (capnolog Drager) to detect ventilation disturbances.

In order to prevent distended rumen and bowel to interfere with diaphragmatic movements and to avold protrusion from the abdominal Inclsion, a tube was inserted Into the munen via the oesophagus. The mostly gaseous distension of the rumen could then be diminished. An $0.9 \% \mathrm{NaCl}$ solution was administered intravenously to the ewe during operation at an infusion rate of $250 \mathrm{ml} /$ hour.

\section{Skin preparation}

The abdominal wall and left flank of the ewe were shaven and thoroughly cleaned with an lodine solution (Betadine ${ }^{R}$ ) several times. The animal was placed in a left tilted Trendelenburg position to avold caval conpression by the pregnant uterus and the legs were fastened upon the operating table.

Recovery

At the end of the operation the halothane ventilation was replaced by oxygen and the ewe was kept in supine position on the operating table until she breathed spontaneously. 
The ewe was placed in the same moblle cant as whlch she stayed in before operation and she recelved food and water ad 11bltum Immedlately after operation.

\subsection{Surglcal procedures}

\subsubsection{Anatony}

For a good understanding of the procedures used and the problems encountered, a description of the anatomy of the pelvic arterlal blood supply in the pregnant ewe is essentlal ( $f$ ig. 2.1).

There is a lot of confusion in the literature in regard to the anatomy and nomenclature of the arterial blood supply to the uterus and related pelvic organs. Moreover the arterial blood supply is a rather complex one.

The abdominal aorta in sheep has another branching at its end compared to the human. After the origin of the external $111 \mathrm{ac}$ artery on both sides, which supplies the hindiegs, the external genttals and the mammae, the vessel continues as the common intemal 1liac artery, sometimes called the comon uterine artery or middle sacral artery (Berman et al 1976), which glves rise to the two intermal 111ac arterles, which in tum give rise to the medial sacral arteries which supply the regio presacralis.

These sacral arteries recelve only $5 \%$ of the blood flow of the common Intemal 111ac artery in pregnancy (Fuller et al 1975, Tabsh et a1 1981). The1r orlgin however can vary considerably. Mostiy they arise from the intemal 11 atc artery about $1-2 \mathrm{~cm}$ after 1 ts origin from the common internal 111ac artery. Sometimes they are seen arising airectiy from the common internal Lllac artery in a caudodorsal alrection. The part of the internal 11 lac artery after the rise of the sacral arterles and before 1ts further branching in the varlous uterine artertes has several names in 11terature: internal 111ac artery, hypogasterio artery or main uterine artery. 


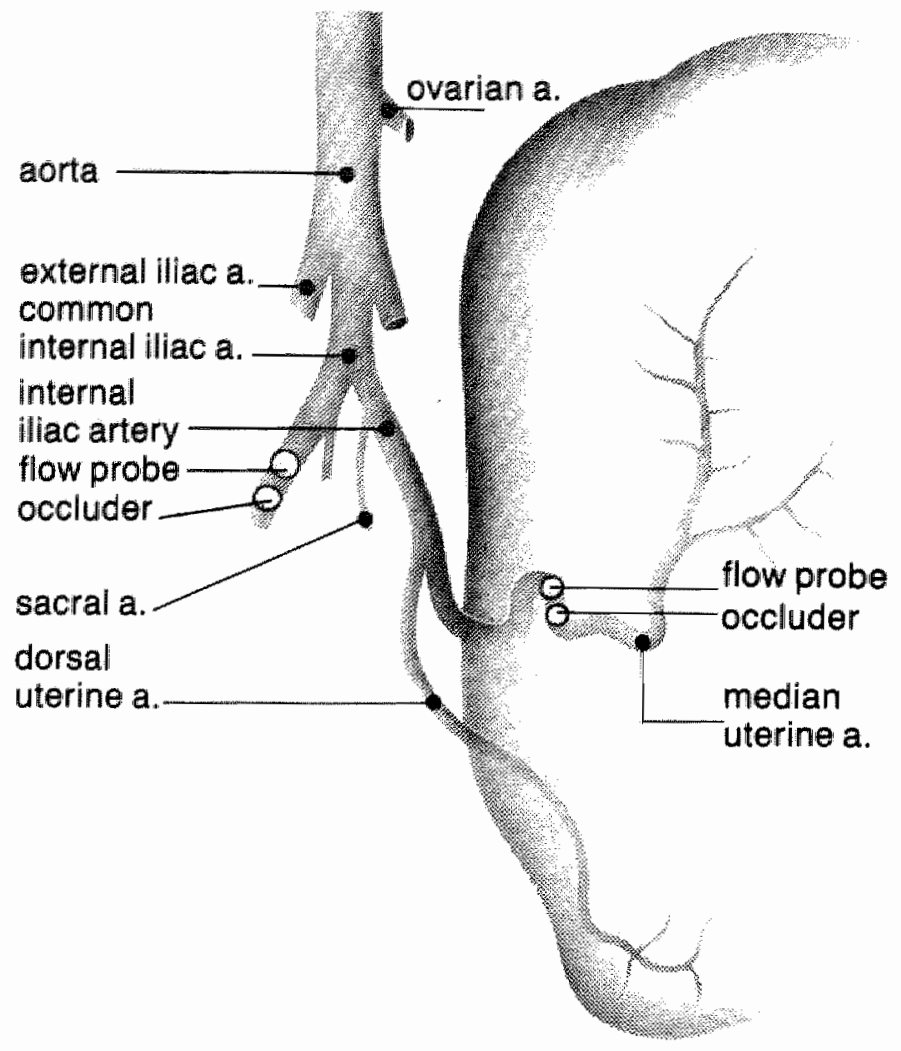

Fig.2.1 The anatomy of the pelvic arterial tree The position of the occluders and flow probes is indicated by open circles (modified from tabsh et al 1981)

In this study the name Internal 1I.1ac artery is used for this vessel from its orloin from the common internal lilac artery till its branching in the different uterine arteries, regardless of the site of origin of the sacral arteries. The internal iliac artery then gives rlse to the median uterine artery, which supplies the uterine homs and a large part of the uterine body and to a smaller vessel, the dorsal or caudal uterine artery, which enters the uterus at the cervicolsthmic 
Junction. From its entry site it subdivides to send three to foum branches longltudinally over the ventral and dorsal surfaces as well as several smaller branches to the cervix. It forms collaterals with the median uterine artery over the ventrolateral surface of the corpus. uteri (Fuller et al 1975, Fuller et al 1978, Evers 1978).

The dorsal uterine artery supplies the lower part of the uterus, the cervix, the bladder and the upper part of the vaglna.

The comon Internal 11lac artery supplies therefore the entire uterus with blood apart from the possible smaller anastomoses vla the ovarlan artery and extrauterine cervical arteries. It forms furthemore the vesical plexus and flnally part of its blood flow 1 s destined for other extra uterine structures via the spatium ischladicum majus (Evers 1978).

\subsubsection{Maternal instrumentation}

A left or Ight paramedian abdominal Incision was made, lateral to the mamary vein on that side.

- Common internal 111 ac artery occluder.

The uterus was lifted out of the true pelvis and outslde the abdominal cavity. The intestines were held away with a soaked gauze and the trifurcation of" the aorta deep in the true pelvis was exposed. The retroperitoneal space over the trifurcation (fig. 2.1) was opened and the vessels exposed by sharp and blunt dissection. A balloon type cuff occluder with a diameter of $6 \mathrm{~mm}$, which was allways large enough to avold partial obstruction of the vessel, was placed around the vessel and secured with a linen tie (fig. 2.2).

The utemis was lifted out of the true pelvis not longer than ninety seconds after which $1 t$ was replaced and a recovery perlod of three minutes was obsemed to let restore uterlne blood flow.

- Internal 111 ac artery occluder and flow transducer.

With the uterus iffed out of the true pelvis and abdominal cavity the internal 11 lac artery (=hypogastric artery) at the side of the pregnant. hom was dissected free from its perlvascular attachnents over a distance of 4 to 5 centimeters. 


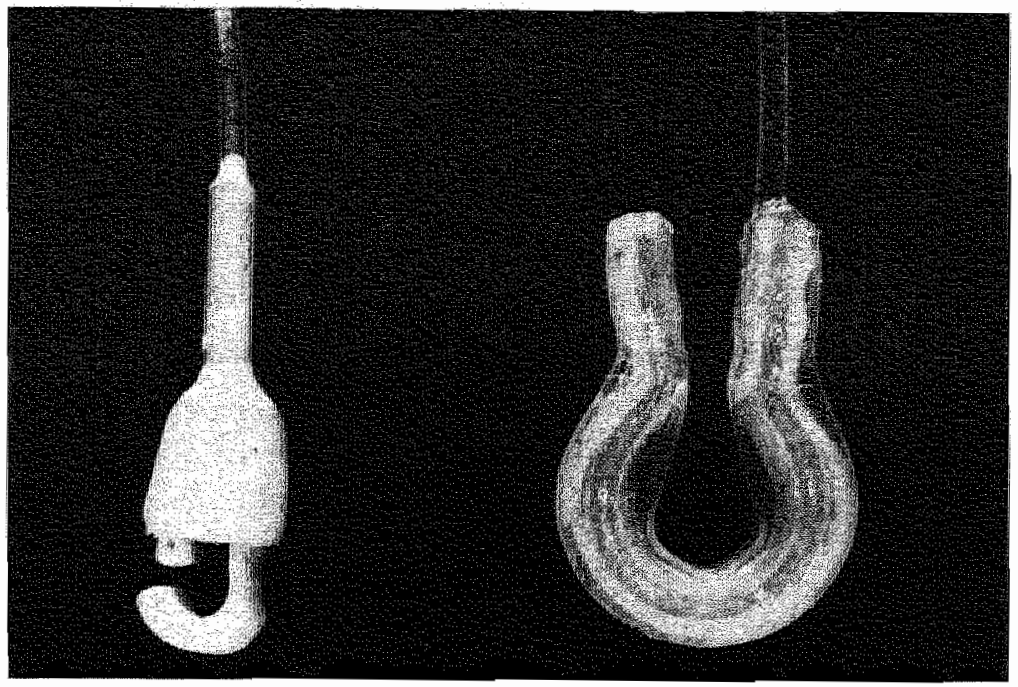

FIG. 2.2 EXAMPLE OF A SMALL. INFLATABLE OCCLUDER (INTERNAL DIAMETER 4 MM, ON THE LEFT SIDE) AND A LARGE ONE (INTERNAL DIAMETER 6 MM, ON THE RIGHT SIDE),

The estimated diameter of the vessel at the polnt of instrumentation varied between 4.0 to $5.5 \mathrm{millmeters.} \mathrm{An} \mathrm{inflatable} \mathrm{balloon} \mathrm{occluder}$ with an Internal diameter of 4 to $5 \mathrm{~mm}$ was placed around the vessel and 1 ts ends tied together $(1 \mathrm{~g} .2 .2)$. Care was taken that the device could not obstruct the blood flow.

Prowlmal to the occluder a cuff type flow transducer with an internal dLameter of 3.5 to $5.0 \mathrm{~mm}$ was placed around the vessel and the opentng In the low transducer was locked whth a slide-slot or with a small plece of polyvinyl tubing. Special attention was given to the size of the flow trensducer w1th a preferred 10\% smaller internal dlameter of the flow transducer than the extemal diameter of the vessel (Gordon 1971, Charbon and van der Mark 3981 ).

Also in thls procedure the uterus was lifted out of the abdominal cavity not longer than ninety seconds with a rest pause of at least 
three minutes to let restore the blood flow to the uterus.

- Median uterine artery flow transducer and occluder.

The median uterine artery at the side of the pregnant hom was exposed before it splits into two or more branches (Soma et al 1971).

The peritoneum was opened 2 centlmeters medlal to the vessel, after Which the vessel was freed from its fine attachnents. An inflatable balloon occluder with an internal diameter of 4 to $4.5 \mathrm{~mm}$ was placed around the vessel and 1 ts end tied together. The internal diameter of the flow transducer ranged from 3.0 to $4.0 \mathrm{~mm}$. The flow tramsducer was locked with a slide-slot or with a small plece of polyvinyl tubling. The Internal diameter of the flow transducer was chosen $10 \%$ smaller than the external diameter of the vessel to obtaln a good vessel contact.

FIG. 2.3 FLOW TRANSDUCER WITH AN INTERNAL DIAMETER OF 6 MM. AND A SLIDE SLOT. A SMALL POLYVINYL WING IS ATTACHED TO THE CABLE OF THE FLOW TRANSDUCER TO GUARANTEE A PERPENDICULAR POSITION OF THE FLOW TRANSDUCER AROUND THE BLOOD VESSEL.

The cables were passed through a tumel under the round IIgament and 
the perltoneum over the vessel was closed. A gnall wing of polyvinyl (118. 2.3) was attached to the cable of the flow transducer at a d1stance of 3 to 5 centimeters of the Now trangducer. Th1s polyvinyl attachment made $1 t$ possible to position the cable and the flow transducer at a $r$ ight angle to the vesisel. The attachment was fixed to the uterine will with sutures.

- Extemal venous catheter.

After closing of the abdominal wall a venous catheter was inserted in a maternal veln, elther a Jugular veln, a mamary vein or a hindleg vein. The catheter was flyed to the maternal skin and continuously flushed with a heparlne solution.

\subsubsection{Fetal instmmentation}

- Femoral artery catheter.

The position of the fetus within the pregnant hom was assessed. The uterjne wall over the fetal pelv1c reglon was stretched between two Babcock clamps and the incision was made parallel with the intramural vessels. Care was taken to avold cotyledons in the area of the Incision. The uterlne wall was opened by means of electrocautery over a distance of 8 to 10 centimeter"s. The membranes were shamply opened and blood vessels in $1 t$ coagulated. The uterine muscle and membranes were clamped with Babcack forceps at four sides. Both hindlimbs were extracted from the uterine horn and the fetal pelvis was exposed. The Inclsion was then covered with a soaked gauze which was also srasped with the Babcock clamps, preventing further mupturing of the uterine wall.

The fetal femoral artery was approached through a groin incision and cannulatied with a polyvinyl catheter louter diameter $1.6 \mathrm{~mm}$; Imner dLameter $0.8 \mathrm{~mm}$; length $150 \mathrm{~cm}$, whlch was advanced into the fetal abdominal aorta. The catheter was flxed and filled with a heparin solution and the skin closed with a continuous suture.

- E.C.G. electrodes.

Three E.C.G. electrodes (length $150 \mathrm{~cm}$ ) were placed subcutaneously on one of the hindlimbs and on elther side of the thorax respectively and ixed. 
-Umbilical cord occluder.

The fetus was then extracted a little further from the uterus until the umbilical insertion was exposed. An inflatable balloon type occluder with an intemal diameter ranging from 10 to $14 \mathrm{~cm}$ was placed around the total umbilical cord in a rather loose fit to prevent obstruction. The occluder was secured with a linen tie and flxed to the fetal abdominal skin with stitches.

- Common intraabdominal umbilical vein flow transducer.

The two umbilical veins fuse immediately after entering the abdomen to form the common intraabdoninal umbilical veln which was approached through an Incision cranial to the umbilicus and parallel to the right costal margin (Soma et al 1971, Oakes et al 1976a) ( $\mathrm{flg} .2 .4$ ). An electromagnetic flow transducer with an internal diameter of 5 to $8 \mathrm{~mm}$ was placed around the vein and the flow transducer was locked with a slide-slot or a small plece of polyvinyl tubing. The flow transducer cable was provided with a polyvinyl wing ( $f$ ig 2.3) at a distance of 3 to $4 \mathrm{~cm}$ from the flow transducer. This attachment was then sutured to the fetal abdominal wall with the flow transducer perpendicular to the umblilical vein. The peritoneal cavity and abdominal wall were closed with sutures.

- Amniatic cavity catheter.

A polyvinyl catheter (length $150 \mathrm{~cm}$, outer diameter $1.6 \mathrm{~mm}$, inner diameter $0.8 \mathrm{rm}$ ) with side holes at its end was placed into the amniotic cavity. The fetus was then carefully replaced in the uterus and in case much amnlotic fluid was lost during surgery, it was supplemented with $0.9 \% \mathrm{NaCl}$ solution. The uterine wall and membranes were closed in two layers with a continuous suture. The exteriorized cable bundle was secured with a purse string suture through the uterine wall. 

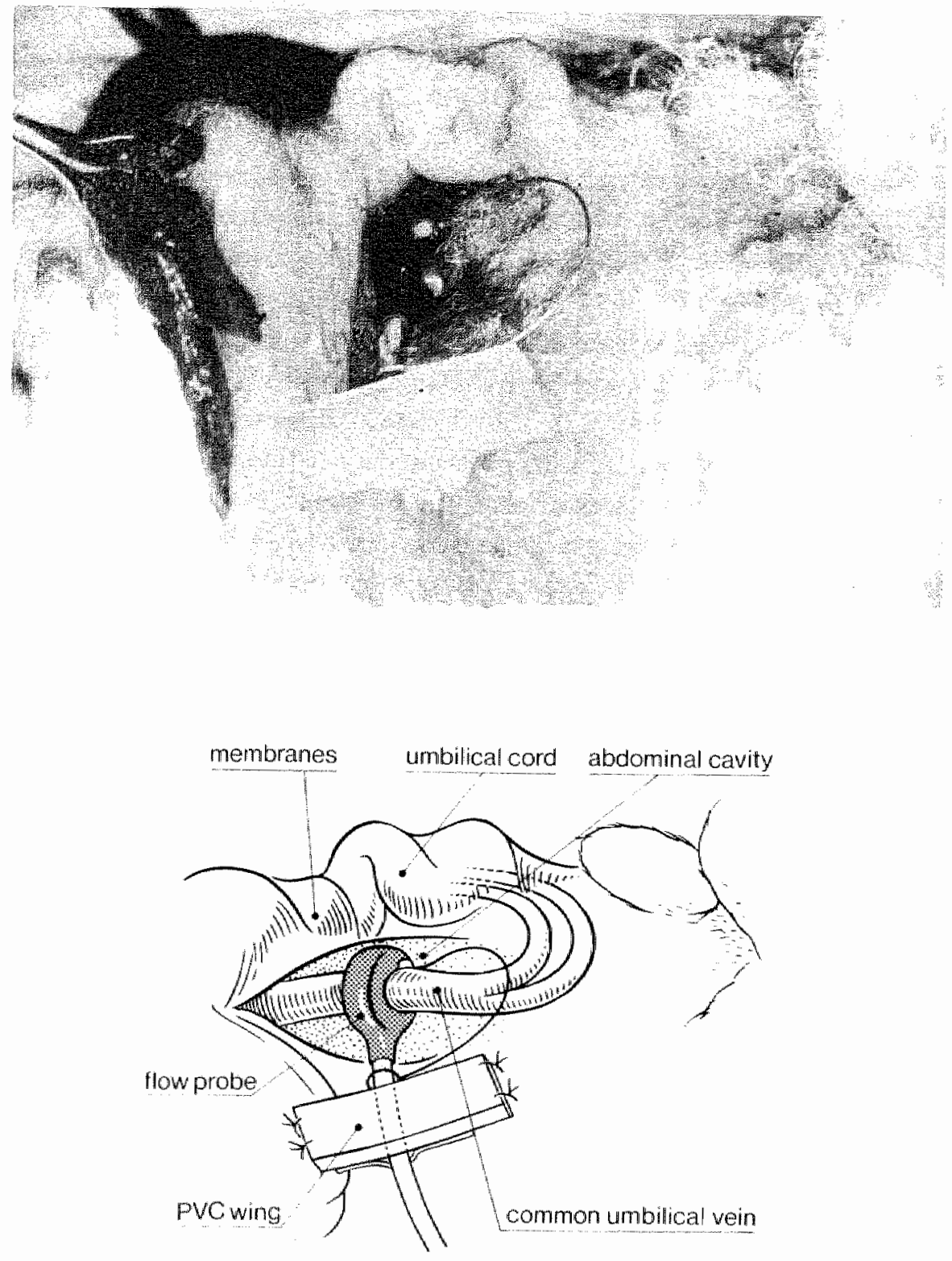

F16.2.4 FLOW PROBE AROUND THE INTRAABDOMINAL COMMON UMBILICAL VEIN IN SITU AND THE SCHEMATIC REPRESENTATION OF ANATOMY, 


\section{- Tracheal catheter.}

For access to the trachea a second inclsion was necessary.

The fetal head was with gentle manlpulation positioned agalnst the uterine wall within an area without cotyledons. With the utemine wall stretched between two Babcock clamps, the uterus was opened with electrocautery over a distance of 4 to $6 \mathrm{~cm}$.The tracheal area was then elther manlpulated towards the incision opening and the skin grasped Wth Babeock clamps or the head was dellvered through the openthe after which the uterine wall, the membranes, a soaked gauze and the petal skin were all together grasped with Babcock forclpes to avold splliling of amnlotic rluid. A transverse incision was made over the trachea below the cricold cartilage. After exposure of the trachea by blunt dissection a polyvinyl catheter (outer dianeter $1.6 \mathrm{~mm}$, inner dlameter $0.8 \mathrm{~mm}$, length $150 \mathrm{~cm}$ ) was inserted through a small stab incision into the trachea over a distance of 5 to $7 \mathrm{~cm}$, depending on the size of the lamb, so that the catheter was situated above the tracheal bifurcation and within the thoracic cavity. The catheter was flxed with a suture on the cartilage rings and after closure of the inclsion also to the fetal skin. After reposition of the fetal head the incision was closed in two layers with a continuous suture. The uterine inclsion through which the catheters were diverted, was secured with a purse string suture.

- Intraabdominal catheter.

In two fetuses a polyvinyl catheter (outer diameter $1.6 \mathrm{~mm}$; Irmer diameter $0.8 \mathrm{~mm}$; length $150 \mathrm{~cm}$ ) was advanced into the abdominal cavity through the inclsion made for application of the flow transducer around the umbllical vein. This catheter allowed intraabdominal pressure measurements during fetal breathing movements.

\subsection{End of the operation}

The catheters, electrodes and flow transducer leads were exterlorlzed via a small inclston on the ewe's left flark. The abdominal wall was closed in two layers with mattress sutures. A pouch was attached to the skin on the ewe's left flank, in which the catheter and cable bundle was protected. 


\subsection{Post-operative care}

\subsubsection{Prophylactic adminlstration of antibiotics}

Although all surgical procedures took place under sterlle conditions, there are numerous sources of infections in chronlc preparations with exteriorized catheters. Therefore in all cases antiblotics were given to the ewe according the following scheme:

-Together with premedication: I gram ampicilin intravenously

to the ewe

-a. Dur』ng surgery

: amplcillin $500 \mathrm{mg}$ intraabdominally ampletilin $500 \mathrm{mg}$ in the amnlotic cavity

$-\mathrm{b}$. The filingt three days : procain penicililin 2.000.000 I.U after surgery and dihydrostreptomycin $2000 \mathrm{mg}$ intramuscularly

In four cases in which there were clinically signs of matemal or fetal intrauterine infection the antiblotics were continued in the same or in another regimen after the third day postoperatively. In the latter case amplcilin $1000 \mathrm{mg}$ or ticarcillin $1000 \mathrm{mg}$ was injected intraamiotically while the ewe recelved additionally metronidazol 500 $\mathrm{mg}$ intravenously or gentamycin $40 \mathrm{mg}$ intravenously.

\subsubsection{Flushing of the catheters}

The fetal arterlal and matemal venous catheter were connected to a caltbrated Infuston pump (B.Braun, Melsungen, type 871100), by means of an external extension catheter, which allowed a continuous flushing during the entire postoperative perfod at a flushing rate of $1.2 \mathrm{ml} / \mathrm{hr}$. The flushing fluld was a $0.9 \% \mathrm{NaCl}$ solution containing 1000 I.U. heparin/looml. 


\subsubsection{Recovery period}

The arterial and venous Infuslon catheters were led through the eye of a $50 \mathrm{~cm}$ long spring attached to the ewe's cart which prevented possible biting of the catheters by the ewe. All animals showed a remarkably fast recovery perlod and were found to be eating and drinking already two or three hours after surgery with no disadvantageous side effects. The total recovery perlod lasted 72 hours. The ewe stayed in the transportable cart during the experimentation period and was taken in principle every day after the recovery period to the laboratory where the catheters and cables were comected to the reglstration equipment and where experiments were done. 


\subsection{Fully equipped animal}

A short overlook of the used instmmentation in one animal is given, if all the equipment had been applied (flg. 2.5).

Ewe: 1. Balloon occluder around the cormon Internal 1liac artery.

2. Balloon occluder around the intemal 1liac artery at the side of the pregnant hom.

3. Electromagnetic flow transducer around the intemal 1Ilac artery at the side of the pregnant horn.

4. Belloon occluder around the median uterine artery at the slde of the pregnant horn.

5. Electromagnetic flow transducer around the median uterine artery at the side of the pregnant horn.

6. Intravenous catheter in elther a jugular vein, marmartan veln or a hindleg veln.

Fetus: 1. Fenoral artery catheter.

2. 3 subcutaneous E.C.G. electrodes.

3. Tracheal catheter.

4. Balloon occluder around the umbilical cord.

5. Electromagnetic flow transducer around the intraabdominal common umbilical veln.

6. Amniotic cavity catheter.

7. Intraabdominal catheter. 


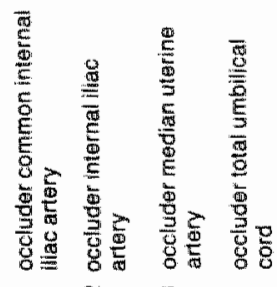

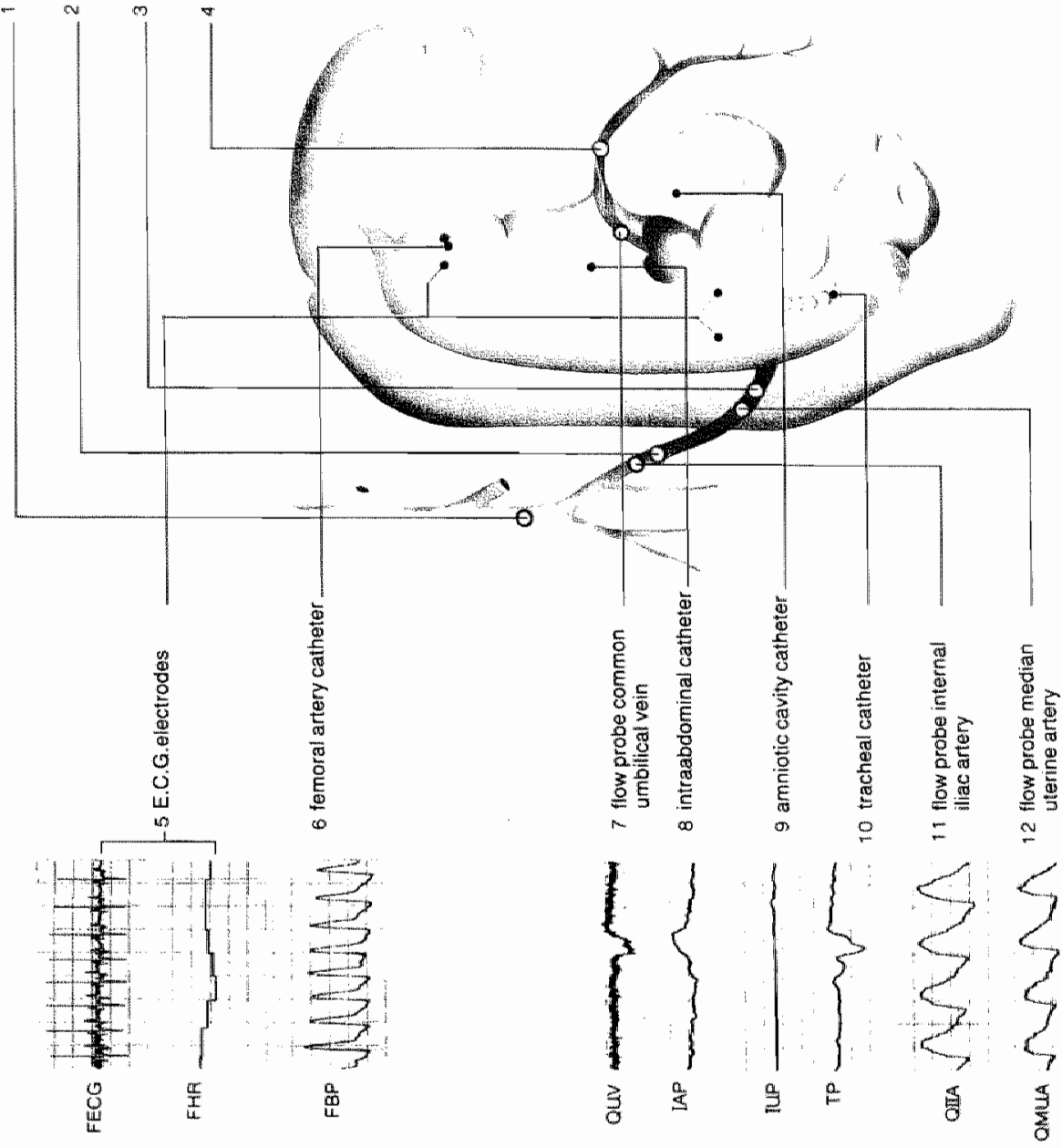

Fig. 2.5 Sthematic representation of the applted materinal and fetal instrumentarium and the recorded signals 


\subsection{Reglistration equipment}

\subsubsection{Electrocardiogram and cardiotachogram}

The three E.C.G. electrodes were connected to a junction box, flued to the cart in which the ewe was stabled after the operation. The signals were led in to a blo-electric amplifier (Hewlett Packard $8811 \mathrm{~A}$ ), where they were filtered and amplifled. From the three electrodes two were chosen which gave the best E.C.G. Signal in regard to the relative amplitudes of the different E.C.G. peaks. The third electrode was used as a reference electrode. The slgnal was displayed on a neonatal monitor (Hewlett Packard 78801 A) with storage facllities and on a six channel monitor (Hewlett Packard $78309 \mathrm{~A}$ ). The fetal cardiotachogram was obtatned from the E.C.G. by means of a signal coupler (Hewlett Packard 8809 A) and displayed on the six channel monitor. The electrocardlogram and the calculated heart rate were displayed on an eight channel strip chart recorder (Hewlett Packard $7758 \mathrm{~A}$ ) and stored on the magnetic tape of an elght channel instrumentation recorder (Hewlett Packard 3968 A).

\subsubsection{Pressure registration}

The fetal arterial, tracheal and amniotic catheters were connected to an extension catheter of polyethylene (length $200 \mathrm{~cm}$, outer diameter $2.0 \mathrm{~mm}$, inner diameter $1.0 \mathrm{~mm}$ ), which material gives less dampening of the pressure wave than the softer polyvinyl. The extension catheters were comnected to a stopcock on the pressure transducer (Hewlett Packard 1293 A) from where the signals were led to a pressure amplifier (Hewlett Packard 8805 D), displayed on the monitors and strip chart recorder and stored on magnetic tape. In order to obtaln a fixed reference point for pressure measurements in the same animal, all pressure transducers were located at the level of the ewe's spine, when she was standing. Each registration was started with an electronlc callbration slgnal, which was in turn in regular intervals callbrated with a mercury colum. 


\subsubsection{Arterlal and venous blood flow measurenents}

The electronagnetic flow transducer connectors were attached to an adapter box, whilch contained a preamplifier (Skalar Transflow 601 system) from where they were led to a recorder module (Skalar "Transfllow 601 system, mdl 400). From the reconder output connectlon the slgnal was led to a low gain DC amplifler (Hewlett Packard 8801 A), displayed on monitor and strip chart recorder and stored on magnetic tape. AlI flow measurements concerned pulsatlle measurements. An external ground reference wire, which needle end was inserted subcutaneously into the ewe's skin, was connected with the flow transducer adapter boxes. Distal to the maternal arterlal flow transducers an inflatable occluder was placed around the vessel which allowed total obstruction of the blood flow and assessment of the baseline reference for zero flow (Reneman et al 1970). Complete occlusion of the umblilical vein was obtained with an inflatable occluder placed around the umblilcal cord. Electromagnetic flow transducers have been used in various forms under experimental conditions (Greiss 1962, Westersten et al 1969, Wyatt 1982) and they have the advantage of instantaneous flow measurements even during rapld flow changes. For a correct flow measurenent however several conditions have to be fulfilled and their sensitivity may change with Implant duration (Astley et al 1979).

We observed in preliminary chronic studies conslderable differences in flow measurements between subsequent days, which could no longer be attributed to the stablilization of the flow transducer to the vessel wall because they also happened incidently several weeks after surgery. These differences in mean flow were especially seen in experimental animals which were provided with two or three flow transducers, which ralsed the susplcion that interference or "cross talk" between these flow transducers in each others proximity occurred with a subsequent base line shift, which experience has been reported by others (Assali et al 1981).

But also flow signals from only one flow transducer in an experimental animal varied sometimes on different days. Mechanical total occlusion of the bloodvessel with a balloon occluder distal to the flow transducer, to keep the vessel distended and its wall in contact with 
the electrodes showed that in those cases a base line shift of the in vitro assessed electronic zero flow meference level had occurred which needed readjustment of the zero balance. It was concluded, that the in wtro assesment of the electronlc zero fow reference level could show baseline shifts in these chronlc experlments with one to three flow transducers simultaneously Implanted. Apart from that, mechanlcally assessing of the zero flow level had a practlcal advantage too. The zero-balance of electromagnetic flow transducers which are used simultaneously must also be set in vitro simultaneously.

Because all flow transducers had to be sterillzed for operation and connecting the llow transducer to the reconding equipment was not posilble during surgery, theoretically the zerombalance of all the avallable flow probes which might be used during operation should be set in vitro before ster111zation in each posislble usable combination, because the slze of the flow transducer that is golng to be implanted, Is dependable of the wessel slze, an unknown factor before operation. Numerous combinations of the in vitro assessed zero balance had then to be made, which seemed at least impractical.

The mechantcal zero-balance of the flow transducers took place at the beginning of each registration and was generally checked at the end of the experimentation session and sometimes during experimentation.

The vessel occlusions were performed simultaneously for all flow transducers in use and during the occlusion the zero-balance of the flow transducers was adjusted in such a way that all flows were at the zero-level; after this procedure the occlusion was discontinued and steady state registratilon began.

The blood flow in the median uterine artery could be conslderably diminished arter an occlusion due to vasospasm. This was seldom the case for the internal 11lac artery flow. If necessary the steady state perlod was prolonged t1.1 flow had retumed to nomal values over a period of at least 30 minutes.

The above mentioned base line shifts did not occur in all experiments. In many cases the mechanically obtalned zero flow balance was rather stable in subsequent experiments, several days after implantation when the flow transducers were attached to the vessel wall by adhesions. 


\subsubsection{Blood sample analysis}

Fetal arterial blood samples were withdrawn from the indwelling femoral artery catheter in an anaerobic way. A total amount of $0.3 \mathrm{ml}$ was sampled for each analysis. After the sampling procedure the catheter and stopcock were flushed with a small amount of heparlinized physiological saline solution. The samples were immediately analysed with an automatic blood gas analyser (AVL 940 automatic gas check). The blood gas analyser had the possibility of presetting the desired temperature and the cholce between adult and fetal Hb preset. Sheep have a higher body temperature $\left(38.5^{\circ}-39^{\circ} \mathrm{C}\right)$ than human belings and since temperature inf"luences $\mathrm{pH}, \mathrm{pCO}_{2}$ and $\mathrm{pO}_{2}$ it would not be correct to analyse blood samples at $37^{\circ} \mathrm{C}$. The samples were therefore analysed at $39^{\circ} \mathrm{C}$ and with the henoglobin switch in the HOF pasition. One should bear in mind the differences in $\mathrm{pH}, \mathrm{pCO}_{2}$ and $\mathrm{PO}_{2}$ analysed at $37^{\circ}$ or $39^{\circ} \mathrm{C}$, when comparing the results of studies done in different research centers. The sampling protocol for the varlous experiments will be explained later on.

\subsubsection{Display and storage of the signals}

All slgnals were displayed on an elght channel strip chart recorder (Hewlett Packard 7758 A) ruming at a paper speed of $3 \mathrm{~cm} / \mathrm{min}$ or 25 $\mathrm{m} / \mathrm{sec}$. A marker signal was added for recagnition of begin and end of an experimental event. All signals were stored on magnetic tape by means of an elght channel instrumentation recorder (Hewlett Packard 3968 A) at a running speed of $15 / 32$ inches/sec.

\subsection{Signal analysis}

\subsubsection{Data processing}

The analog signals stored on magnetic tape were subsequently converted to digital signals and processed by a computer (Digital VAX 11/780). The sampling rate for each parameter was $250 \mathrm{~Hz}$. All data were stored on disk and magnetic tape after conversion. 


\subsubsection{Data reduetion}

Before statistical analysis could be performed, means and standard deviations of each approprlate varlable were calculated during a steady state period pregeding the experimental event, during the experimental event and during a period following the event.

In case of an umblilical cord occlusion or an intemal 1liac artery occlusion the steady state perlod lasted 40 seconds, followed by a varying occlustion period and a recovery perlod of 120 seconds. Means and standard deviations of the fetal parameters were calculated over this total epoch in Intervals of 10 seconds each.

The same procedure was followed in the experiments with agonists and antagonists of the autonomic nervous system adninistered to the fetus, but the total duration of the postinfusion perlod varied for each specific drug (chapter 5).

In the matemal infusion experiments means and standard deviations were calculated over intervals of flive minutes at varlous moments during the experiment, as wr1.1 be elucidated in chapter 6 .

\subsubsection{Artefact Ident1fication}

Matermal and fetal movements can cause disturbances in the recorded slgnals.

This is most obvious in the recordings of the pressure signals. Each change in intra or extra uterine pressure fron elther fetal or matemal slde 1 s superinposed on the pressure wave propagated by the catheters. The amniotic cavity pressure was therefore subtracted from the fetal arterlal pressure to minimize pressure artefacts.

Those cases in which no rellable amnlot1c cavlty pressure was obtalned due to blocking or klnking of the catheter, were discarded from the study. Also the occlusion experiments in whlch the arterial pressure slgmal was lost as the result of blood sampling procedures immediately following the occlusion were excluded from the analysis of the hemodynamic changes of the varlables. Interference with the Ech-s Lgnal: by electrical muscular activity with fetal movements was neglected, 
because no electromechanical time intervals or heart rate indices derived from $\mathrm{RR}$ intervals had to be calculated.

Fetal movements sometimes disturbed the blood flow slgnel fron the common umbilical vein, most likely caused by displacement of the flow transducer around the vessel. If this was the case in the short lasting occlusion experiments or the experiments with drug administration to the fetus, they were excluded from analysis.

Changes in the matemal blood flow measurements can occur when the ewe is frightened by e.g. unexpected movements of the investigator, which may decrease uterine blood flow (Hasaart and de Haan 1983b). Cautlous behaviour of the investigator helped to prevent these reactions, otherwlse they were excluded from analysis.

Postural changes of the ewe may also lead to slight changes in pelvic blood flow (Hasaart and de Haan 1983b).

The ewe was permitted to stand or lie as pleased, a condition Important in longer lasting experiments with muinants.

\subsubsection{Statistical analysis}

Comparison of the mean values of the variables was done by means of the Wilcoxon matched-pairs signed-ranks test or by means of a paired student's t-test.

All p values were calculated for two talled tests.

\subsection{Experiments}

A total number of 15 animals was used in this study (table 2.1). Experimental sessions were not started before the third day after surgery. The experiments took place between 103 and 142 days' gestation. Fetal postoperative survival ranged from 5 days to 35 days with a mean of 17.1 days ( $S D \pm 3.1$ days).

Maternal body weight at the time of surgery ranged forn 36 to 47 kilograms with a mean of $42 \mathrm{~kg}(\mathrm{SD} \pm 1.9 \mathrm{~kg})$. 


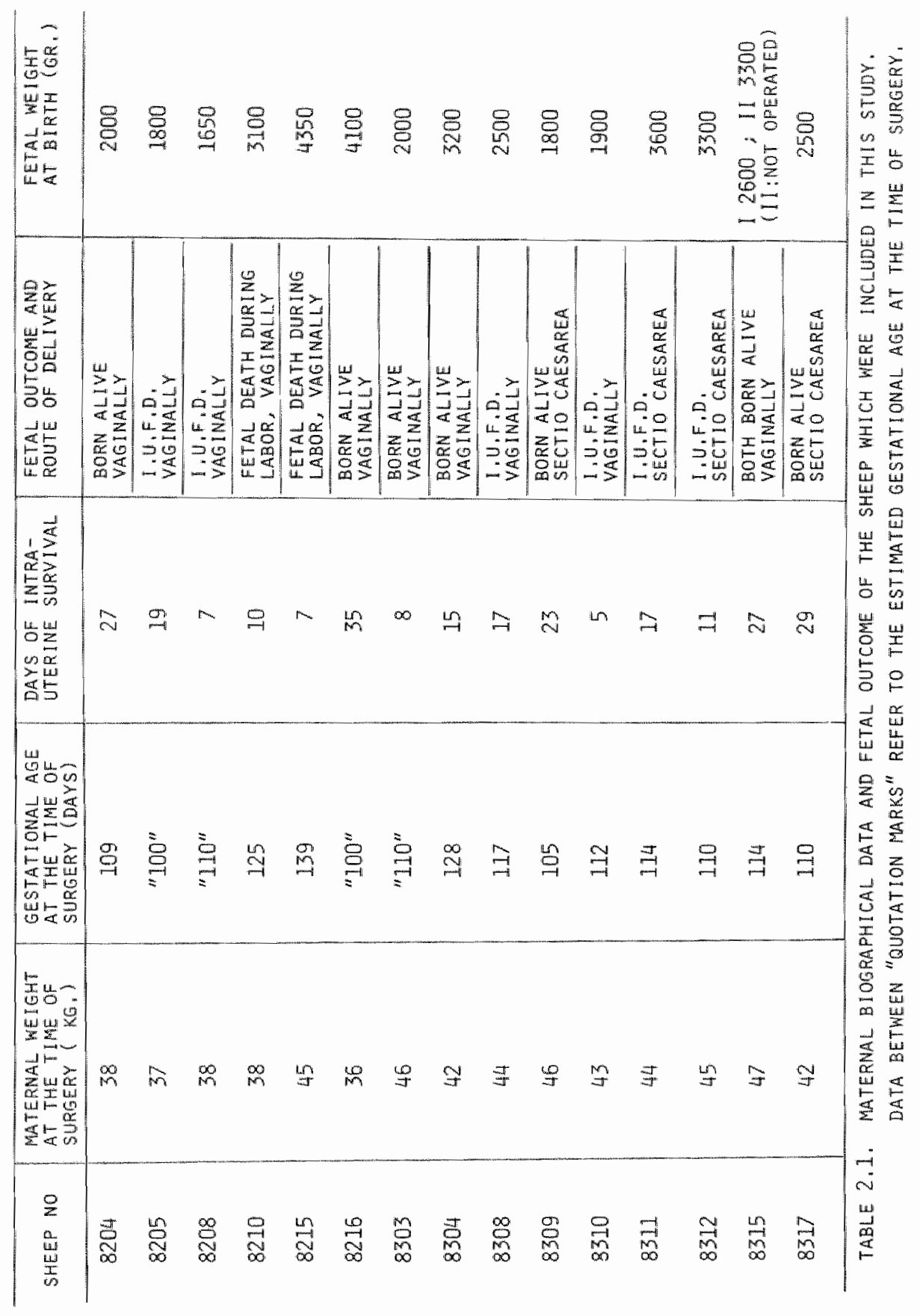




\begin{tabular}{|c|c|c|c|c|}
\hline & MEAN & $S D$ & RANGE & $N$ \\
\hline $\begin{array}{l}\text { GESTATIOMAL AGE AT THE } \\
\text { TIME OF SURGERY IN DAYS }\end{array}$ & 113.5 & \pm 3.2 & $100-139$ & 15 \\
\hline $\begin{array}{l}\text { GESTATIONAL AGE AT THE } \\
\text { TIME OF DELIVERY IN DAYS }\end{array}$ & 130.8 & \pm 3.2 & $117-146$ & 15 \\
\hline $\begin{array}{l}\text { FETAL POSTOPERATIVE } \\
\text { SURVIVAL IN DAYS }\end{array}$ & $17 . \mathbb{1}$ & \pm 3.1 & $5-35$ & 15 \\
\hline $\begin{array}{l}\text { FETAL BODY WEIGHT AT THE } \\
\text { TIME OF DELIWERY (GRAMS ) }\end{array}$ & 2690 & \pm 30 & $1650-4350$ & 15 \\
\hline $\begin{array}{l}\text { WATERNAL BODY WEIGHT AT } \\
\text { THE TIME OF SURGERY ( KG.) }\end{array}$ & 42 & \pm 1.9 & $36-47$ & 15 \\
\hline
\end{tabular}

TABLE 2.2

BIOGRAPHICAL DATA OF THE ANIMALS IMCLUDED IN THIS STUDY

( $S D=$ STANDARD DEVIATION)

( $N=$ NUMBER OF ANIMALS,

Fetal body welght at the time of delivery ranged from 1650 grams to 4350 grams with a mean of 2690 grams (SD \pm 30 grams) (table 2.2).

Not all animals were fully equlpped with the devices listed in paragraph 3.6 , since not all identical measurements were performed in all animals. Moreover, 1t was not always posstble to place all devices, for example due to the stze of the fetus (table 2.3).

The experiments whlch were performed are divided in different groups. which w111 be subsequentily discussed. 


\begin{tabular}{|c|c|}
\hline SHEEP NO & APPLIED IMSTRUMENTARIUM. \\
\hline 8204 & $1,2,3,5,6,9,11,12$ \\
\hline 8205 & 1.2 .4 .5 .6 .7 .9 .11 \\
\hline 8208 & $1,2.3,4,5,6,7,9,11,12$ \\
\hline 8210 & $1,2,3,4,5,6,7,9,11,12$ \\
\hline 8215 & 1.2 .3 .5 .6 .9 .11 .12 \\
\hline 8216 & 1.2 .3 .4 .5 .6 .7 .9 .11 .12 \\
\hline 8303 & $1.2 .3,4,5,6,7,9,10 \cdot 11,12$ \\
\hline 8304 & $3,4,5,6,7,9,10,12$ \\
\hline 8308 & $1,2,3,4,5,6,7,9,10,11,12$ \\
\hline 8309 & $1,2,3,4,5,6,7,9,10,11,12$ \\
\hline 8310 & $1 \cdot 2 \cdot 3 \cdot 4 \cdot 5 \cdot 6,7 \cdot 8 \cdot 9,10 \cdot 11,12$. \\
\hline 8311 & $1,2,3,4,5,6,7,8,9,10 \cdot 11,12$ \\
\hline 8312 & $1,2,3,4,5,6,7,9,11,12$ \\
\hline 8315 & $1,2,3,4,5,6,7,9,11,12$ \\
\hline 8317 & $1,2,3,4,5,6,9,10,11,12$ \\
\hline
\end{tabular}

TABLE 2.3. LISTING OF THE APPLIED MATERNAL AND FETAL INSTRUMENTARIUM IN EACH ANIMAL. THE NUMBERS CORRESPOND WITH THOSE IN FIG. 2.6. , INDICATING THE CATHETER FLOWMETER, OCCLUDER OR ELECTRODE IN QUESTION,

Only those fetal lambs were included in the study, whose $\mathrm{pH}$ and $\mathrm{pO}_{2}$ were within the normal range (mean \pm 2 SD) for this laboratory (table 2.4).

The nomal ranges were detemtned by averaging the steady state values whithin a prevlous group of 18 fetal sheep operated in the set up phase of this chronla aninal model, from the third day after operation onwards with exclusion of the day of delivery.

Mean $p d$ values were assessed by averaging the negatlve antilogarithm of each pH value, and subsequently converting this mean negative 
antllogarith (mean hydrogen lon concentration) into the mean pH to avold arlthmetic errors (Bretscher 1966).

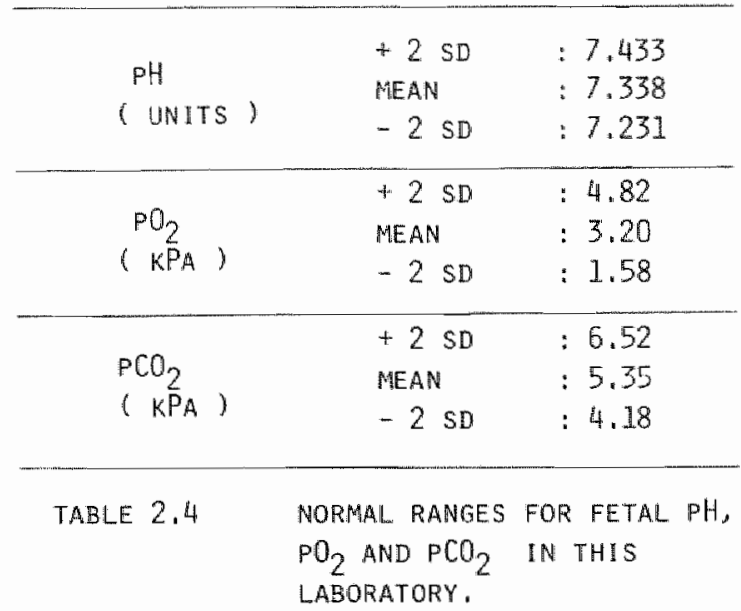

\subsubsection{Unbilical cord occlusions}

An inflatable balioon occluder was placed around the total umbilical cord in 8 fetuses which were also provided with an electronagnetic flow transducer around the Intraabdoninal common umbilical vein. The balloon was inflated with saline solution until no further filling of the balloon could be obtained. The occluston period ranged from 20 to 90 seconds. In most experiments several occlusions after each other were performed with intervals of three to four minutes.

The unbllical cord occlusions with simultaneous registration of the blood flow in the internal illac and/or median uterine artery are shown in table 2.5 . 


\begin{tabular}{l|c|c|}
\hline OCCLUS ION OF THE UMBILICAL CORD \\
IMTERRAL ILIAC ARTERY & 69 & 7 \\
MEXP. ANIMALS \\
\hline
\end{tabular}

TABLE 2.5

SUMMARY OF THE PERFORMED UMBILICAL CORD OCCLUSIONS WITH SIMULTANEOUS MEASUREMENT OF THE BLOOD FLOW IN THE MATERNAL ILIAC ARTERY AND/OR MEDIAN UTERINE ARTERY.

\subsubsection{Common internal 1liac artery occlusions}

Fetal hypoxemia can be established in several ways. One of the two mostly used techniques of producing fetal hypoxemia in the chronic animal model are causing maternal hypoxenta and hence fetal hypoxemia by lowering the oxygen content of the inspired air by placing a bag around the ewe's head and ventilating $1 t$ with low oxygen mixtures. The other method is interrupting the maternal placental blood flow to the fetus by occlusion of the supplying arteries. This blood flow obstruction can be established at different levels in the arterlal tree from the abdominal aorta onwards to the uterine arteries. One of the important effects of the uterine contraction, namely the transient reduction of the matemal placental blood flow can thus be mimicked. Occluston of the maternal abdoninal aorta by an indwelling balloon occluder via the femoral artery can obstruct the maternal placental clrculation almost completely, but rupture of the aorta is a dangerous complication of this method. Occlusion of even both median uterine arteries does in general not result in the desired fetal hypoxemia (Evers 1978).

Occlusion of the cormon internal Illac artery by a balioon occluder which surrounds the vessel is a safe method and causes also a nearly 
complete obstmotion of matemal placental flow.

Inis method was used in this study. The completeness of the bilood flow obstmetion could be judged by the decrease of the flow in the Intermal Illac artery or median uterine artery to zero measured with an electromagnetic flow transducer. The occlusion perlad ranged between 30 and 250 seconds, except in three experiments after propranolol administration, in which the occlusion time was extended up to 340 seconds before an effect could be noted. Several subsequent occluslons were perforned with intervals of three to four minutes. Blood samples for analysis of fetal $\mathrm{pH}, \mathrm{pO}_{2}$ and $\mathrm{pCO}_{2}$ were drawn at the end of the steady state period before the beglnuing of the occluston expertments and immediately after the last occlusion. The experiments are listed in table

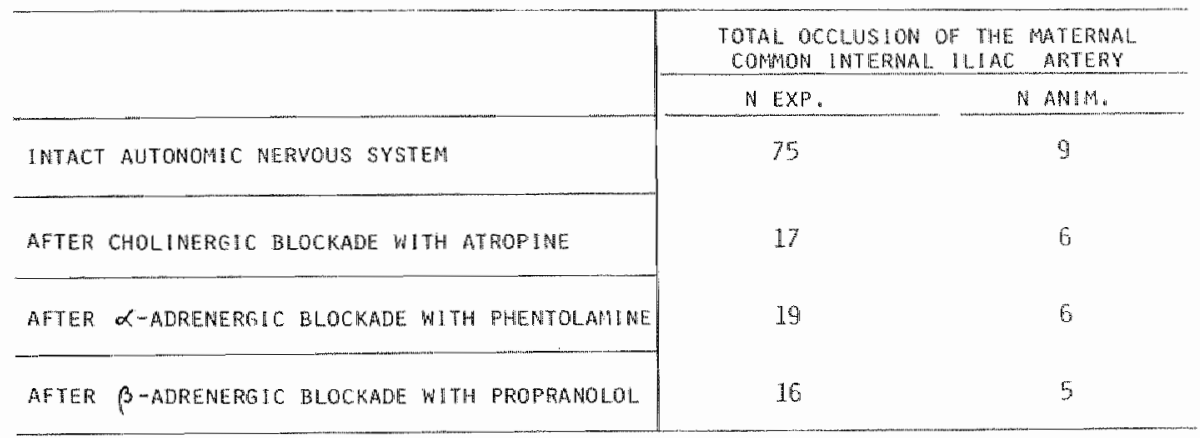

TSBLE 2.6

SUPAHARY OF THE COMMON INTERNAL ILIAC ARTERY OCCLUSHONS WITH AND WTHOUT THE MDMINISTRATION OF AUTONOHIC MCTING AGENTS TO THE EOTUS.

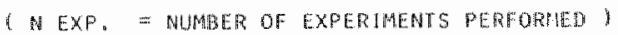

( $A N$ ANM, = NUMBER OF ANI HWLS INVOLVED

\subsubsection{Occlusion experiments after selective autonomic nervous system blockade}

The infiluence of various parts of the autononic nervous system upon unbllical venous blood flow durtng acute hypoxemta caused by occiuston of the maternal common intemal 11 ac artery was studied by blocking 
the dufferent parts of the autonomic nervous system with antagonistic drugs. The drugs were admintstered to the fetus via the indwelling fenoral artery catheter in a bolus injection.

The glven doses were related to the estimated fetal welght according to Naaktgeboren's fetal development scales (Naaktgeboren and Stegeman 1969). The completeness of the autononic blockade with the used doses has been proven by Evers (1978), who found Inhlbition of the effects of their respective agonists.

\subsubsection{Parasympathetic or cholinerg1c blockade w1th atropine}

Seventeen occlusion experiments of the maternal internal 11.1ac artery were performed in six animals. Seven occlusion experiments of the total unbillical cord were done in four animals. Atropine was administered in a dosage of $1.0 \mathrm{mg} / \mathrm{kg}$ estimated fetal weight.

\begin{tabular}{|c|c|c|c|c|}
\hline & AGONIST & $\begin{array}{c}\text { DOSE } \\
\text { MICROG./KG. }\end{array}$ & $\begin{array}{l}\text { NUMBEER } \\
\text { OF EXP. }\end{array}$ & $\begin{array}{l}\text { NUMBER } \\
\text { OF ANIM" }\end{array}$ \\
\hline CHOL MMERGIC & ACETYLCHOLIME & $5-25$ & 45 & 5 \\
\hline ALFHAM-ADRENERGIC & NOREPINEPHR INE & $2-5$ & 28 & 7 \\
\hline BETA-ADRENERG IC & FENOTEROL & $0.5-1.0$ & 8 & 3 \\
\hline
\end{tabular}

THALE 2.7 SUMMARY OF THE EXPERIMENTS PERFORMED IN THE FETAL LARES WITH AGONISTS OF THE AUTONONIC NERVOUS SYSTEM.

\subsubsection{Beta-adrenergic blockade w1th propranolol}

Sixteen occlusion experinents of the matemal common internal 11 lac artery were performed in five animals. Eight occlusion experiments of the total umbilical cord were performed in four animals. Propranolol was admlnistered in a dose of $1.0 \mathrm{mg} / \mathrm{kg}$ estimated fetal weight. 


\subsubsection{Alpha-adrenergic blockade with phentolamine}

Nineteen occlusion experiments of the maternal common internal 11 lac artery were performed in six animals. Eleven occlusion experiments of the total umbilical cord were performed in four animals. Phentolamine was administered in a dose of $2.5 \mathrm{mg} / \mathrm{kg}$ estinated fetal weight.

\subsubsection{Studles with autonomic acting agents}

Apart from the occlusion experiments under selective autononic nervous system blockade agonists and antagonists of the autonomic nervous system were administered to the fetus to study their effects on umbilical venous blood flow. All dmugs were admlnistered by bolus Injections to the fetus via the femoral artery catheter (table 2.7 and 2.8).

\begin{tabular}{|c|c|c|c|c|}
\hline & & DOSE & NUMBER & NUMBER \\
\hline & ANTAGONIST & $\mathrm{MG} . / \mathrm{KG}$ & DF EXP. & of ANIM, \\
\hline CHOLANERGIC & 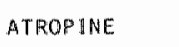 & 1,0 & 7 & 6 \\
\hline ALPHA-ADRENERGIC & PHENTOLAMINE & 2.5 & 9 & 6 \\
\hline BETA-ADRENERG IC & PROPRANOLOL & 1.0 & 7 & 5 \\
\hline
\end{tabular}

TABLE 2.8 


\subsubsection{Matemal infusions with acetylcholine, norepinephrine and fenoterol}

The blood flow responses of the pelvic vascular bed in the pregnant ewe to vasoactive stimuli and their possible effects on the fetal circulation were studied with the autonomic agonists acetylcholine, noreplnephrine and Penoterol. These three drugs have different properties. Acetylcholine has a cholinergic effect, whlle noreplnephrine has mainly alpha-adrenergic activity with very little beta-1 activity on the heart. Fenoterol 1 s a beta-adrenergic acting drug with malniy beta-2 activity. Fenoterol was chosen to cover the beta-adrenergic part because of the fact that this drug is also used in the human for tocolysis (Fenoterol=Partusisten ${ }^{R}$ ). With the use of these three drugs the various parts of the autonomic nervous system were 1nfluenced. A total number of 58 infusion experiments were performed in 12 pregnant sheep between 104 and 146 days gestation.

\begin{tabular}{|c|c|c|c|c|c|c|}
\hline & \multicolumn{2}{|c|}{ FENOTEROE } & \multicolumn{2}{|c|}{ NOREP I NEPHARINE } & \multicolumn{2}{|c|}{ ACETYLCHOL INE } \\
\hline & $N$ EXP. & N ANIM. & A EXP. & N ANYM. & NEXP. & ANLM, \\
\hline AMTERNAL INTERNAL ILIAC ARIERY & 15 & 4 & 7 & 5 & 7 & 4 \\
\hline MATERHAL MEDIAN UTERINE ARTERY & 18 & 6 & 13 & 8 & 15 & 5 \\
\hline FETAL COMMON UADULICAL WEIN & 20 & 7 & 13 & 9 & 12 & 5 \\
\hline
\end{tabular}

TAULE 2.9 MUMEER OF EXPERIMENTS IN WEATCH THE BLOOD FLOH IN RESPECTIVELY THE INTERAAL ILAMC ARTERY. MEDIAN UTERIME ARTERYY AND COMMON WMBILICAL VEIN WAS MEASURED DURING THE ADMINISTRATION OF FENOTEROL, NOREPINEPHRINE AND ACETYLCHOL INE TO THE EWE.

The internal lliac artery and medtan uterine artery blood flow at the side of the pregnant horn were not simultaneously measured in all 
experiments. The reasons for the fact that in part of the experinents only the flow in one matemal vessel was measured were twofold. Elther only one flow transducer was placed or one of the flow transducers around the matemal vessels lost its grip on the vessel during the experimental period and subsequently no slgnal was obtained.

A detailed ilst of the various experinents with the number of blood flow measurements in each vessel is given in table 2.9 .

\subsubsection{Infusion protocol}

The drugs were administered intravenously to the ewe via an indwelling catheter in elther a Jugular vein, a manmary veln, or a hindieg vein. The insertion place of the catheter varled, because relnsertion at another location was sometimes necessary, when the catheter was blocked or was lost by the ewe"s manoeuvres. The drug solutions were continuously infused by means of a perfusion pump (B. Braun Melsungen, type 871100).

The extension catheter and the stopcock whllch connected the syringe containing the drug solution and the maternal venous catheter were fllled with the selected drug solution prior to the start of the infusion to avold any lag time between the start of the Infusion and the arrlval of the drug in the ewe's venous circulation. "The doses of" the drug were increased during the Infusion period by increasing the infusion rate, which varied between $1.2 \mathrm{ml} /$ hour and $60 \mathrm{ml} /$ hour.

The experimental protocol for these tests comprised the frollowlng perilods:

1. A control period of 30 minutes was observed durlng whlch the blood flows in the internal 1llac artery and/or the medlan uterlne artery as well as the avallable fetal parameters were recorded continuously. At the end of the control period a fetal arterial blood sample was withdrawn for analysis of fetal actd base balance.

2. A testing perlod then followed, during which the selected drug was. infused intravenously in progressively increasing dose, each infusion lasting 15 minutes, but in the cases with fenoterol infuslon, the infusion period amounted 30 minutes. Doses, Infusion perlods and the number of experiments for each drug are enlisted in table 2.10. 


\begin{tabular}{|c|c|c|c|c|}
\hline & $\begin{array}{c}\text { DOSE } \\
\text { (MICROGR.JMIN) }\end{array}$ & $\begin{array}{l}\text { IAFUSION THEE } \\
(\text { MDUTES }\end{array}$ & $\begin{array}{l}\text { PUPABER OF } \\
\text { EXPERIMEVTS }\end{array}$ & $\begin{array}{l}\text { WUVWBER OF } \\
\text { AHP MMALS }\end{array}$ \\
\hline FEMOTEROL & $\begin{array}{l}2 . \\
4\end{array}$ & $\begin{array}{l}30 \\
30\end{array}$ & 24 & 7 \\
\hline WOREP I NEPHARIAE & $\begin{array}{l}4 \\
8 \\
20 \\
40\end{array}$ & $\begin{array}{l}15 \\
15 \\
15 \\
15\end{array}$ & 17 & 10 \\
\hline ACETYLCHOL IAEE & $\begin{array}{l}20 \\
50 \\
100 \\
200\end{array}$ & $\begin{array}{l}15 \\
15 \\
15 \\
15\end{array}$ & 17 & 7 \\
\hline
\end{tabular}

TABLE 2,110

DOSES AMD UNFUSION TIMES OF FENOTEROL, NOREPINEPHARINE AMD MCETYLCHOLINE AND THE NUHBER OF EXPERIMENTS PERFORMED WHICH EACH QRug.

During this period blood flow in the Internal 1liac artery and/or median uterine artery was recorded continuously together with fetal parameters. Fetal acid base balance was determined at the end of the drug infusion period.

3. A post infusion period of 30 minutes was allowed during which flows and fetal parameters were recorded continuously. A third fetal arterial blood sample was withdrawn for fetal acid base balance determination at the end of the post infusion perlod of 30 mInutes.

Only one drug was studied in each animal on any one day. The absolute drug doses used in this study were the same for each animal and not related to the bodywelght of the ewe. The reasons therefore were several. First of all it was not the aim of the expertments to assess dose-response curves. Secondly the bodywelght of the ewes did not vary that much with a mean body weight of $42.8 \pm 1.9$ $\mathrm{kg}$ (mean $\pm \mathrm{SD} ; \mathrm{n}=12$; range $36-47 \mathrm{~kg}$ ).

Moreover the bodywelght of the ewe was not constant over the experimental period with advancing gestation and it was rather 
Impractical if not impossible to perform dally welght measurenents wthout severing the indwelling catheters.

The doses of norepinephrine and acetylcholine were in the range that other investigators have used for these kind of experiments in sheep. The infused amount of fenoterol per $\mathrm{kg}$ maternal body welght corresponded with the drug doses per $\mathrm{kg}$ maternal body weight used in the human for tocolysis.

\subsubsection{Fetal breathing movements, fetal intraabdominal pressure and common umbilical vein flow}

The influences of fetal breathing movements on the blood flow of the conmon umbilical vein was studied by simultaneous registration of tracheal pressure, amniotic fluid pressure and comnon umbilical vein blood flow in 6 fetal lambs from the third postoperative day onwards. Perlods with and without fetal breathing movements were discerned by Inspection of the analog record.

The effects of acute hypoxemia caused by occlusion of the maternal comon internal 11 lac artery and the fetal umblilical cord on fetal breathing movements could be studied in relation w1th umbilical venous blood flow.

The relation between fetal breathing movenents, intraabdominal pressure and amniotic fluid pressure was studied in two fetal lambs. 

CHAPIER III

COMMON INTERNAL ILIAC ARIERY OCCLUSIONS AND UMBILICAL VENOUS BLOOD FLOW

\subsection{Introduction}

Late decelerations in the fetal heart rate are generally considered to be a sign of fetal hypoxemla. The fetal heart rate pattern of late deceleration in the human is characterized by a uniform specific fetal heart rate pattern, whose shape reflects the shape of the associated uterine contraction curve and whose onset is late in the contracting phase of the uterus (Hon 1968). The major factor in the production of late decelerations is a translent decrease in uterine blood flow during contractions and a concomitant decrease of fetal oxygenation below the limit of fetal tolerance. Late decelerations mostly occur in conditions In which the duration of uterine contractions is too much for the fetus that is already at the limits of 1 ts reserves, as e.g. In pre-eclampsia or chronically impaired placental exchange. They also occur in Instances in which uteroplacental perfusion 1 s acutely diminished as a result of, for example, uter.ne hypertonus, maternal cardlovascular shock and partial abruptio of the placenta.

Fetal hypoxemia can be established in several ways as has been shown in paragraph 2.10.2. Producing matemal and fetal hypoxemia by lettung the ewe insplre a low oxygen content gas mixture differs in two aspects substantlally from the production of fetal hypoxemia by means of uterine bload flow obstruction. The latter method namely implies also major hemodynamic changes in the utertne vascular bed, comparable to those occurring during uterine contractions. The flrst technlque not only leads to retal hypoxemia but general matemal hypoxenla is establlshed too.

Periodic uterine contractions whlch lead to fetal hypoxemla are 
difficult to produce in a controllable way in the chronlo sheep preparation, so that most of the animal studies concerning late decelerations are performed by blood flow obstruction in the matemal abdominal aorta or soniewhere downstream in the uterine vascular bed (Parer 1976). Although the effects of hypoxemia and acidemia on umbllical blood flow under several condltions are well known, all these experiments took place with the ewe breathing low oxygen content mixturea (Cohn et al 1974, 1980, 1982). Only scarce data are avallable on the influences of acute uterine flow decrease on arterial umbilical blood flow (Beman et al 1976, Parer et al 1980, Harris et al 1982). No data exist to our knowledge on the effects on umbllical venous blood flow as measured with an electronagnetic flow transducer.

The ilterature on the late decelerations in the fetal heart rate and especially lts relation with umbilical blood flow will be briefly reviewed.

\subsection{Literature}

The late deceleration fetal heart rate pattern in the human was ascribed by Hon (1962) to hypoxemic depression of the myocardium. As evidence for this mechanism Hon showed that late decelerations in human fetuses could be modifled by the administration of $100 \%$ oxygen to the mother. However data from both Hon (1962) and Mendez-Bauer et al (1963) suggested that there was also a vagal reflex component to the mechanism of late deceleration. They observed that parasympathetic blockade with atroplne, injected into human fetuses with late decelerations, could modify but not completely eliminate this phenomenon in the fetal heart rate pattern. Later animal studies were directed upon the hypoxic depression of cardlac performance.

James et al (1972) observed in anesthetized subhuman primates that the severity of the late decelerations was lessened as the fetal arterlal oxygen tenston was increased. The same results were obtalned by Meyers et al (1973) who showed in acute monkey preparations in which late decelerations were provoked by transient matemal aortic occlusion, that the severity of the late deceleration was related to the degree of fetal hypoxemla. Boddy et al (1974) showed on the other hand in the 
chronically catheterized fetal lamb that the Initlal bradycandia, assoclated with acute hppoxemia can be abollshed by vagotomy. The hypoxemle bradycardia can also be converted to a tachycardia by cholinergic blockade (Parer 1977, פvers 1978).

Martin et al (1979) and de Haan et al (1979) described the mechanlsms of late decelerations in fetal lambs in a study perfomed with autonomic blocklng agents. The late decelerations were induced by periodic acclusion of the maternal comon internal 111 ac artery for 30-60 seconds. The nonacidemic fetuses in their study responded to periodic reductions in uterine blood flow by periodic hypertension and fetal heart rate decelerations. Elimination of the fetal hypertensive response by alpha-adrenerglc blockade markedly modifled the fetal heart rate decelerations, but did not eliminate then completely. Cholinemic blockade converted the perlodic decelerations to accelerations, whlch in turn could be blocked by propranolol. When the alpha-adrenerglc, chollnergic and beta-adrenergic parts of the autonomic nervous system were blocked simultaneously, the nonacldemic fetuses showed essent1ally no heart rate response to perlodic hypoxemla, indlcating that the heart rate deceleration during hypoxemia is mediated by the autonomic nervous system.

In contrast, blockade of the efferent $1 \mathrm{mb}$ of the cardlodecelerator reflex (by cholinerglc blockade) did not alter the degree of fetal heart rate deceleration in response to periodic occlusion of the maternal common internal 11 lac artery in fetuses made severely acldotic by a long serles of such occlusions. They concluded that the dominant reflex-mechanlsm Lnvolved in "acute" late decelerations would be chemoreceptor-medlated reflex vasoconstrlction (Dawes et al. 1968b, 1969), produclng hypertension and, in turn, baroreflex-lnduced cardiac slowing (Sh1neboume et al, 1972). Martin et al (1979) furthernore state that chemoreceptor (peripheral or central) stimulatilon by hypoxemia can also activate a cardiodecelerator reflex primarily, as is suggested by the frequent onset of heart rate deceleration several seconds before the appearance of any blood pressure increase in the unblocked fetuses in thelr experiments.

The interpretation of Harr1s et al (1982) and Itskovitz et al (1982a) of the concluslons of Martin and coworkers that the decrease in fetal 
heart rate was primarily due to a baroreflex mechanism is therefore not correct.

Martin et al concluded moreover that the reflex component of the late deceleration was absent or minimal under conditions of severe fetal ac1dosis, and direct hypoxic depression of myocardial rhythicity seemed to be the major determinant of the late deceleration during hypoxic acidosis.

Hypoxenla decreases the rate of spontaneous impulse inftiation in the sinoatrial node (Senges et al 1979) with slowing of the heart rate as result and may furthermore affect contraction force of the myocardium resulting in a decrease of the heart minute volume.

Berman et al (1976), in a study on pressure flow relationships in the umblilcal and uterine circulations of the sheep, reduced uterine arterial pressure and thus flow to the placenta by inflating a Swan-Ganz catheter in the descending aorta of the ewe. Umbilical arterlal blood flow was measured continuously during this procedure by means of an electromagnetic flow transducer around the common umbilical artery of the fetus (Beman et al 1975). They concluded that uterine blood flow decreased instantaneously after reduction of uterine arterlal pressure, whereas umbilical bloodflow did not change inttlally. A varlable and delayed fall in umbilical blood flow subsequent to fetal hypoxemia could result from the reduced uterine arterial nlow. They supposed that the bradycardia due to fetal hypoxemia (Cohn et al 1974) might be responsible for the late fall in umbllical blood flow, because the prevention of the bradycardia by atroplne abollshed the decrease in umblilcal blood flow assoclated with the hypoxemic response.

Parer et al (1980) produced late decelerations in the fetal heart rate by abruptly decreasing uterine blood flow to zero for 20 seconds in chronically instrumented normoxemic sheep. Uterine flow reduction was accomplished by inflation of a balloon in the maternal abdominal aorta. Fetal $\mathrm{O}_{2}$ consumption, $\mathrm{O}_{2}$ content and $\mathrm{O}_{2}$ tension in umbilical blood decreased signiflcantly before the decline in heart rate. Fetal arterlal blood pressure elther showed no change (nine experiments), an increase (fifteen experiments) or a decrease (five experiments) following aortic acclusion. The mean value of fetal artertal blood 
pressure actually showed a slight, though nonsigniflcant, decline with aortic occlusion. Only minor changes in unbilical blood flow were found with aortic occlusion and no value was significantly different from control. After complete vagal blockade with atropine the late deceleration disappeared and a late acceleration was uncovered, which was due to beta-adrenergic activity. No change in mean fetal arterial blood pressure occurred, but a substantial decline in umblilical venous oxygen tension was present during aortic occlusion. Thelr final conclusion is therefore that these late decelerations caused by short lasting obstruction of the aortic blood flow in normoxemic fletal sheep are primarily vagally mediated and due to chemoreceptor rather than baro-receptor activity. Further evidence for the primary roll of the chemoreceptors in the onset of fetal bradycardla during late decelerations is the abolishment of fetal bradycardia during short lasting maternal aortic occlusion after denervation of the fetal aortic and carotid chemoreceptors (Itskovitz 1982b).

In a continuation of the study by Parer et al (1980), Harmis et al (1982) published the results of a study into the mechanism of late decelerations of the fetal heart rate in fetal lambs which were already made hypoxemic before the obstruction of uterine blood flow. The ewes were made hypoxemic by breathing a low oxygen gas mixture through a mask placed over their faces. Transient maternal aortic occlusion during 20 seconds in these hypoxemic ewes resulted in a delayed and transient deceleration of the fetal heart rate in the hypoxemic fetuses, associated with a significant decrease in mean fetal arterial pressure and umbl11cal arterlal blood flow as measured with an electromagnet1c flow transducer. Parasympathetic blockade of the fetus with atropine modifled but did not abollsh the fetal heart rate response with aortic occlusion nor did it restore umbilical blood flow completely. The conclusion was that late decelerations result from two mechanisms: a chemoreceptor medlated vagal reflex and hypoxic myocardial depression. Itskovitz et al (1982a) studied the responses of fetal heart rate and blood pressure to a translent reduction in uterine blood flow during 10 or 20 seconds in normoxemic and chronically hypoxemic fetal lambs. Uterine flow reduction was established by inflating a balloon in the maternal abdominal aorta. In normoxemic 
fetuses, a reduction in uterline blood flow, if prolonged sufficiently, produced reflex bradycardia mediated through chemoreceptors. The bradycardia was assoclated with a marked decrease in left ventricular output as measured by an electronagnetic flow transducer around the ascending fetal aorta. Both phenomena, the bradycardia as well as the decrease in left ventricular output were abollshed by atropine, Indicating that hypoxemic depression of the sinoatrial node ald not occur.

In chronically hypoxenic fetuses, a reduction in uterine blood flow produced a late deceleration in heart rate, which consisted of three components: reflex bradycardla due to chemoreceptor stimulation, baromeceptor-mediated reflex bradycardia associated with the hypertensive pertod, which involved the slow and late recovery of the heart rate, and nonreflex bradycardia which was probably secondary to hypoxic depression of the sinoatrial node. No data on left ventricular output upon uterine flow reduction in the hypoxemic animals were avallable in these study. Their conclusion is that the response of fetal heart rate to a transient reduction in uterine blood flow is related to the duration of the reduction and to the status of fetal oxygenation prior to the reduction in uterine blood flow. The same flow changes as occur in the ascending aorta might be expected in the comon urbilical artery, but the effects of flow redistribution ("Sparschaltung") during these events must be taken into account when comparing the flow changes in these two vessels.

\subsection{Sumary}

Summarlzing the studies from different research centers, there seems to be little disagreement on the mechanism of the late deceleration. The most important factor which determines the reaction in the fetal heart rate pattern during uterine blood flow reduction 1 s the oxygenation of the fetus prior to the decrease in uterine flow (Itskovitz et al 1982a), as was already descibed by Meyers et al in 1973, and furthermore the degree of hypoxemla which is reached as the flow reduction advances.

The primary mechanlsm in the fetal heart rate decline in nomoxemic 
fetuses is vagally mediated by chemoreceptors in response to the decrease in arterial $\mathrm{pO}_{2}$. As the uterine flow reduction advances then an indirect vasoconstriction-baroreceptor mechanlsm during fetal hypertension reinforces the bradycardia. If hypoxenta becomes severe then a non-reflex bradycardia due to direct depression of cardiac rhythicity is eventually added.

Itskovitz et al (1982a) suggested that direct bypoxic myocardial depression occurred with an arterial $\mathrm{pO}_{2}$ around 10 torr. Martin et al (1979) supposed myocardial depression to play a role rather early in the course of fetal acidemta at a $\mathrm{pH}$ between 7.25 and 7.30. Th1s nomreflex bradycardla due to direct hypoxic myocardial depression plays a substantial role in the development of bradycardla in hypoxemic fetuses and may occur from the beginning of the heart rate deceleration in severe hypoxemic and acldemic fetuses.

The changes in the arterial umbilical blood flow that accompany the heart rate decelerations seem also to be dependent on fetal oxygenation. Short reductions of matemal aortle blood flow to zero up to 20 seconds did not affect umbilical arterial blood flow in the experiments by Berman et al (1976), Rudolph (1976) and Parer et al (1980) in normoxemlc fetuses. Berman et al and Rudolph however reported a decrease in umbllical blood flow as fetal hypoxemia and bradycardia developed with advanoing flow obstruction. Umbilical arterlal blood flow always decreased upon a short lasting maternal aortilo flow reduction in fetuses which were already hypoxemic before the onset of the uterine flow reduction and this fall in unblilcal flow could not be prevented by atropine (Harris et al 1982).

No data are avallable on the umbllical venous blood flow during late decelerations, nor are the umblilcal blood flow reactions known durlng longer lasting uterine blood flow obstruction with the subsequent deterioration of fetal oxygenation.

In order to study the effects of late decelerations on umblllcal venous blood flow, periodic occlusions of the matemal comon Internal illac artery were performed. The roles of the fetal parasympathetic, alpha-and beta-adrenergic systems were determined by blockade of each of these brances of the fetal autonomic nervous system. 


\subsection{Materials and methods}

A total number of one hundred twenty seven occlusions of the matemal common internal 1liac artery in nine fetuses were analysed.

Seventy five occlusions were performed in nine fetuses with an intact autonomic neryous system, while the remaining fifty two occlusions were done in seven fetuses with a selective blockade of a part of the autonomic neryous system. The distribution of the occlusions over the several groups is given in table 2.6.

The occlusion time for the total group ranged from 30 to 340 seconds. The occlusions were performed in series ranging from two to seven occluslons per experimental session.

\subsection{Results}

\subsubsection{Changes in fetal arterial pH and blood gases}

Table 3.1 shows the values for arterlal pH, blood gases and base excess during the control period prior to the start of the acclusions.

$$
\begin{aligned}
& \mathrm{PH} \pm \mathrm{SD} \text { (UNITS) } 7.36 \pm 0.036 \\
& \mathrm{PQ}_{2} \pm \mathrm{SD}(\mathrm{KPA}) \quad 3.23 \pm 0.81 \\
& P C O_{2} \pm S D(\mathrm{KPA}) \quad 5.24 \pm 0.67 \\
& \mathrm{BE} \pm \mathrm{SD}\left(M E N / L_{1}\right)-2.6 \pm 1.4
\end{aligned}
$$

\footnotetext{
TABLE 3.1 FETAL ARTERIAL PH, BLOOD GASES AHD

BASE EXCESS DURING THE CONTROL PERIOD

IN 31 EXPERIMENTAL SESSIONS.
} 
The data of the fetal acid-base balance immediately after the last occlusion of each experimental session are shown in table 3.2. The repetitive short lasting occlusions of the maternal comon internal 1liac artery resulted in a decrease in fetal $\mathrm{pH}$ and $\mathrm{pO}_{2}$, whlle fetal $\mathrm{pCO}_{2}$ increased.

$$
\begin{aligned}
& \mathrm{PH} \pm \mathrm{SD}(\text { UNITS }) \quad 7.31 \pm 0.05 \\
& \mathrm{PO}_{2} \pm \mathrm{SD}(\mathrm{KPA}) \quad 2.76 \pm 0.79 \\
& \mathrm{PCO}_{2} \pm \mathrm{SD}(\mathrm{KPA}) \quad 5.70 \pm 0.90 \\
& B E \pm S D(M E Q / L,)-4.8 \pm 1.6
\end{aligned}
$$

TABLE 3.2 FETAL ARTERIAL PH, BLOOD GASES AND BASE

EXCESS IMMEDIATELY FOLLOWING THE LAST

OCCLUSION OF THE COMMON INTERNAL ILIAAC

ARTERY OF EACH EXPERIMENTAL SESSION

$(N=28)$,

The differences between the values from the control period and the values obtained at the end of each serles of occlusions were slgnlficant at the $\mathrm{p}<0.01$ level for $\mathrm{pH}, \mathrm{pO}_{2}$ and base excess and at the p $<0.02$ level for $\mathrm{pCO}_{2}$ (student"s t-test for palied observations).

\subsubsection{Intact autonomic nervous system}

In sixty nine of the seventy flwe occlustons a deceletation in the fetal heart rate occurred. In the remalning s:1x accluslons in two sheep no heart rate deceleration was seen (ocoluston time 60-120 seconds), now a change in arterial blood pressure and umbll1cal venous blood flow. The minimal occlusion time causing heart rate decrease showed a great interanimal varlation, but the intraanimal varlation with different occlusions was quite small. 
The overall effect was a fetal heart rate decrease after an inftial delay during each occlusion and a gradual recovery after the occlusion period (filf. 3.1). Fetal arterial blood pressure however showed a varyling response during the occlusion, namely elther an increase or a decrease in mean arteriai pressure.

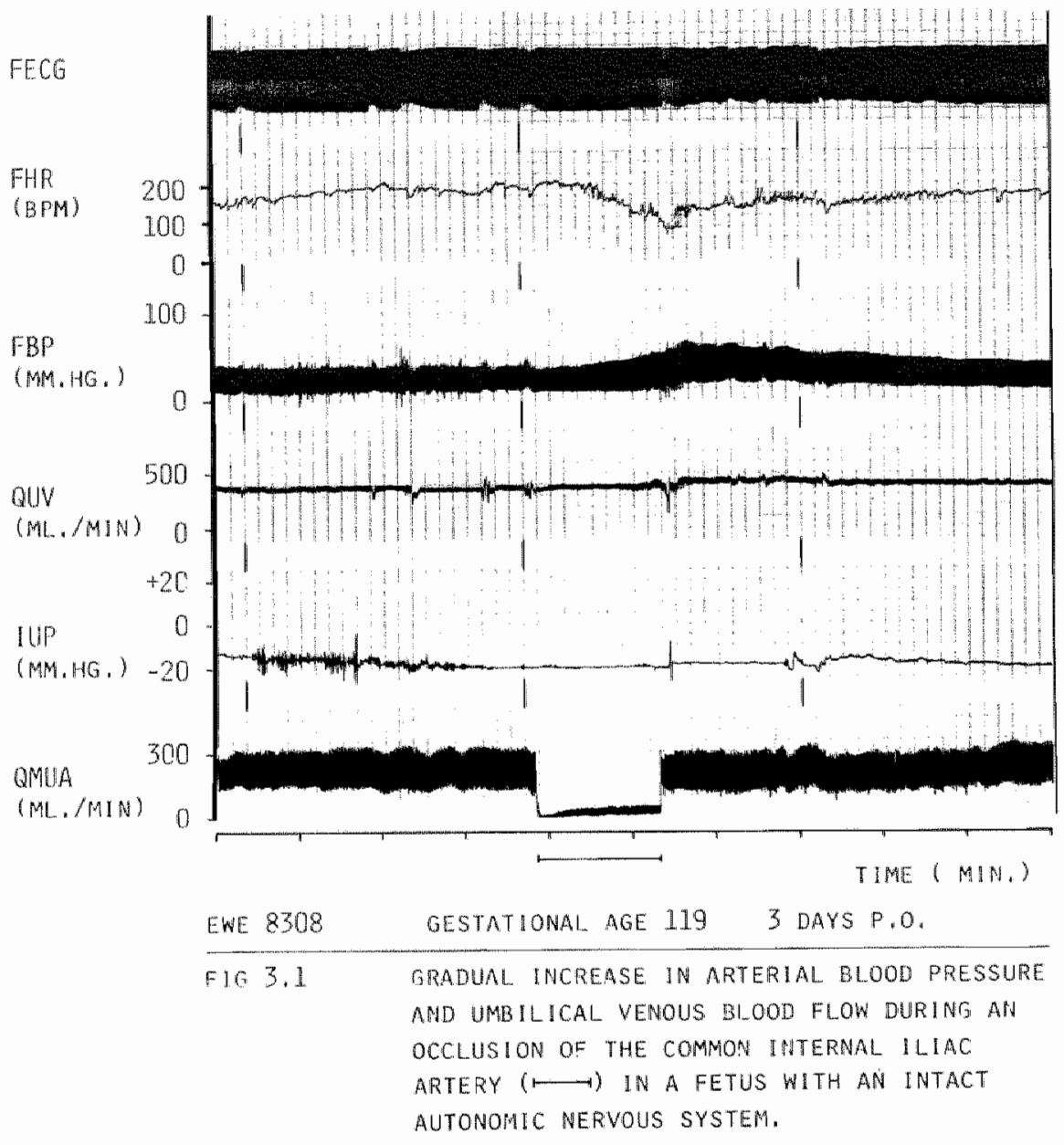


To Imvestigate the factor's, e.g. fetal $\mathrm{pO}_{2}$, which were lrwalved in this varying blood pressure response and to establish the relationshlps of arterlal blood pressure with the other cardlovasoular data, further analysis was performed in two groups.

The individual data of the sixty nine occluslons were therefore divided In two groups with the arterlal pressure response at the end of the occlusion period as criterion.

In thirty six occlusions mean arterlal blood pressure was increased at the end of the occluslon compared with the control value preceding the acclusion (group I). In the remaining thirty three occlusions a decrease in mean arterial blood pressure was found at the end of the occlusion compared with the value of the control period (group II).

The mean values of fetal heart rate, arterlal blood pressure and umbllical venous blood flow over an interval of 10 seconds were pooled for each group and statist1cally analysed. The control values ( $=C$ ) were obtalned from a period 10 seconds before the start of the occlusion. Control values were then compared w1th the mean values calculated from the last 10 seconds of the occlusion $(=E)$, the interval 10 to 20 seconds after the occlusion $(=10)$, the Interval 30 to 40 seconds after the acclusion $(=30)$, the interval 60 to 70 seconds after the occlusion $(=60)$ and flnally with the mean value about two minutes after accluslon $(=120)$, calculated over the interval $110-120$ seconds after the occlusion.

Data were expressed as percent change \pm SEM with control values as the 100\% reference level.

Statistical analysis was performed by means of W1lcoxon"s matched-palns sligned ranks test. All p-values were calculated for two tajled tests.

In twelve experimental sesslons an increase in mean arterial blood pressure was found during all the perfomed occlustons ( $n=19)$. In eleven experimental sesslons arterial blood pressure invarlably decreased during al1 occlusions $(n=17)$.

In the remalning elght experimental sessions blood pressure elther Increased $(n=17)$ or decreased $(n=16)$ during the occlusions. In the latter elght remaining experimental sessions with mixed blood pressure responses, the same trend in time was found in flve experimental 
sesslons: an lncrease in blood pressure was assoclated with the first occlusions ( $n=13)$, whle a decrease in blood pressure was noted in the following occlusions $(n=12)$. Flgures 3.2 and 3.3 show such an example of the reversal in blood pressure response in an occlusion perfomed early in the experimental gession compared with an occlusion performed after seven foregoing occlusions.

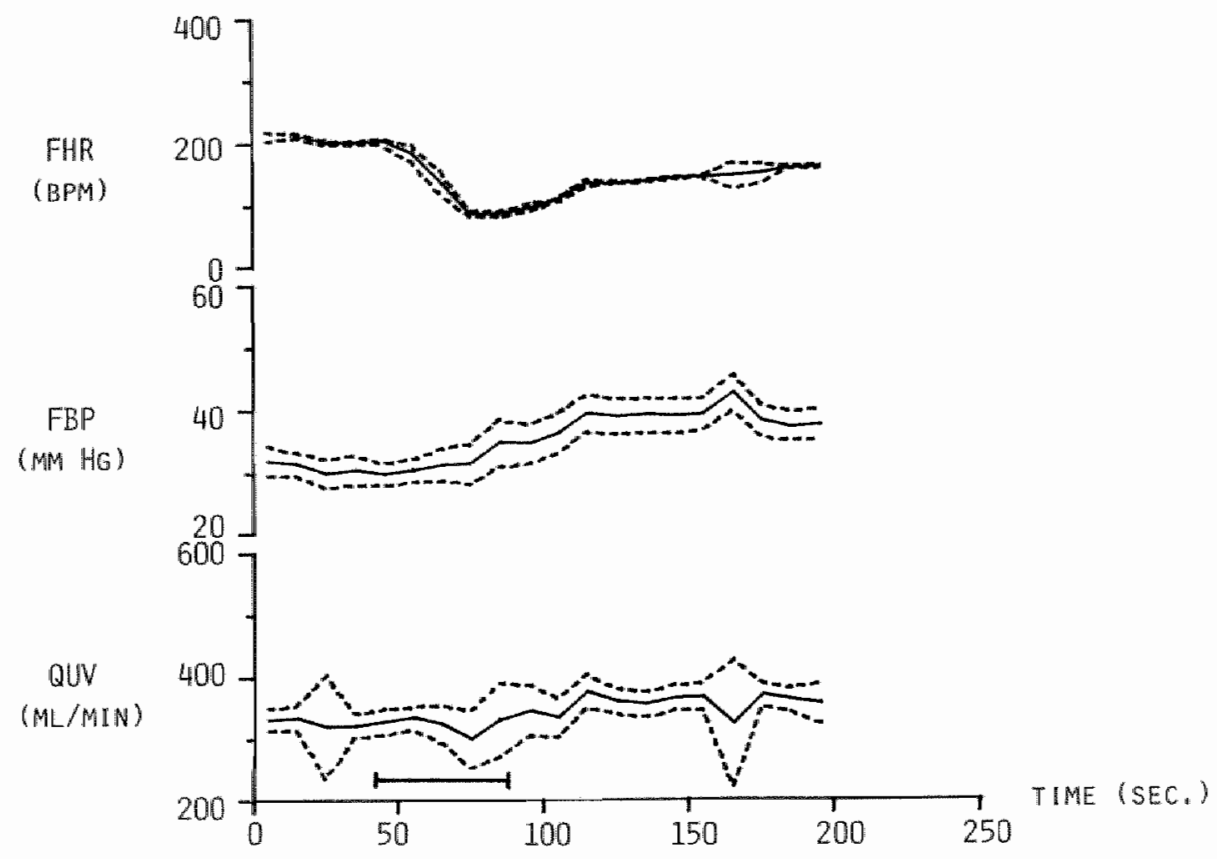

FIG. 3.2 INCREASE IN ARTERIAL BLOOD PRESSURE AND UMBILICAL VENOUS BLOOD FLOW DURING AN OCCLUSION OF THE COMMON

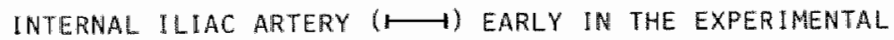
SESSION. DATA ARE EXPRESSED AS MEAN \pm SD IN INTERVALS OF 10 SECONDS. 
Either increase or decrease in mean arterlal blood pressure started after an inttial delay period from the beginning of the occlusion.

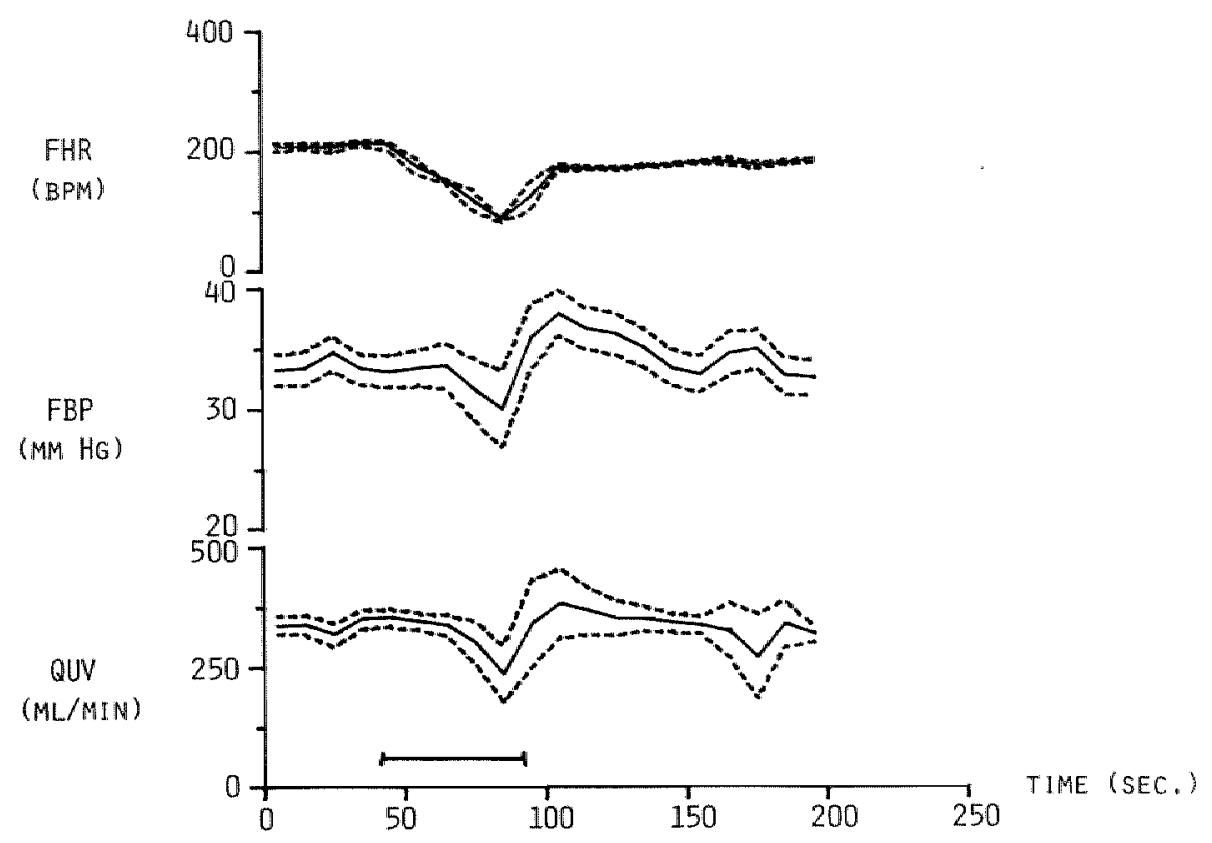

FIG. 3.3 DECREASE IN ARTERIAL BLOOD PRESSURE AND UMBILICAL VENOUS BLOOD FLOW DURING AN OCCLUSION OF THE COMMON

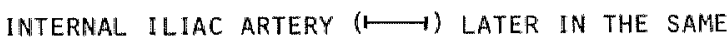
EXPERIMENTAL SESSION AS IN FIG, 3.5. DATA ARE EXPRESSED AS MEAN \# SD IN INTERVALS OF 10 SECONDS.

Figure 3.4 shows mean values \pm SD for heart rate, arterlal blood pressure and umbilical venous blood flow of an occlusion in an antmal reacting with a hypertensive response, while fig. 3.5 shows the same parameters of an occlusion in an antmal whose mean artertal blood pressure decreased.

If hypertension was present then fetal. blood pressure returned towards control levels after the acclusion ( $11 \mathrm{~g}$. 3.4). In the case of a hypotensive response however, blood pressure increased again after the end of the occlusion with of ten a hypertensive response during the recovery phase (f1g. 3.5 ). 


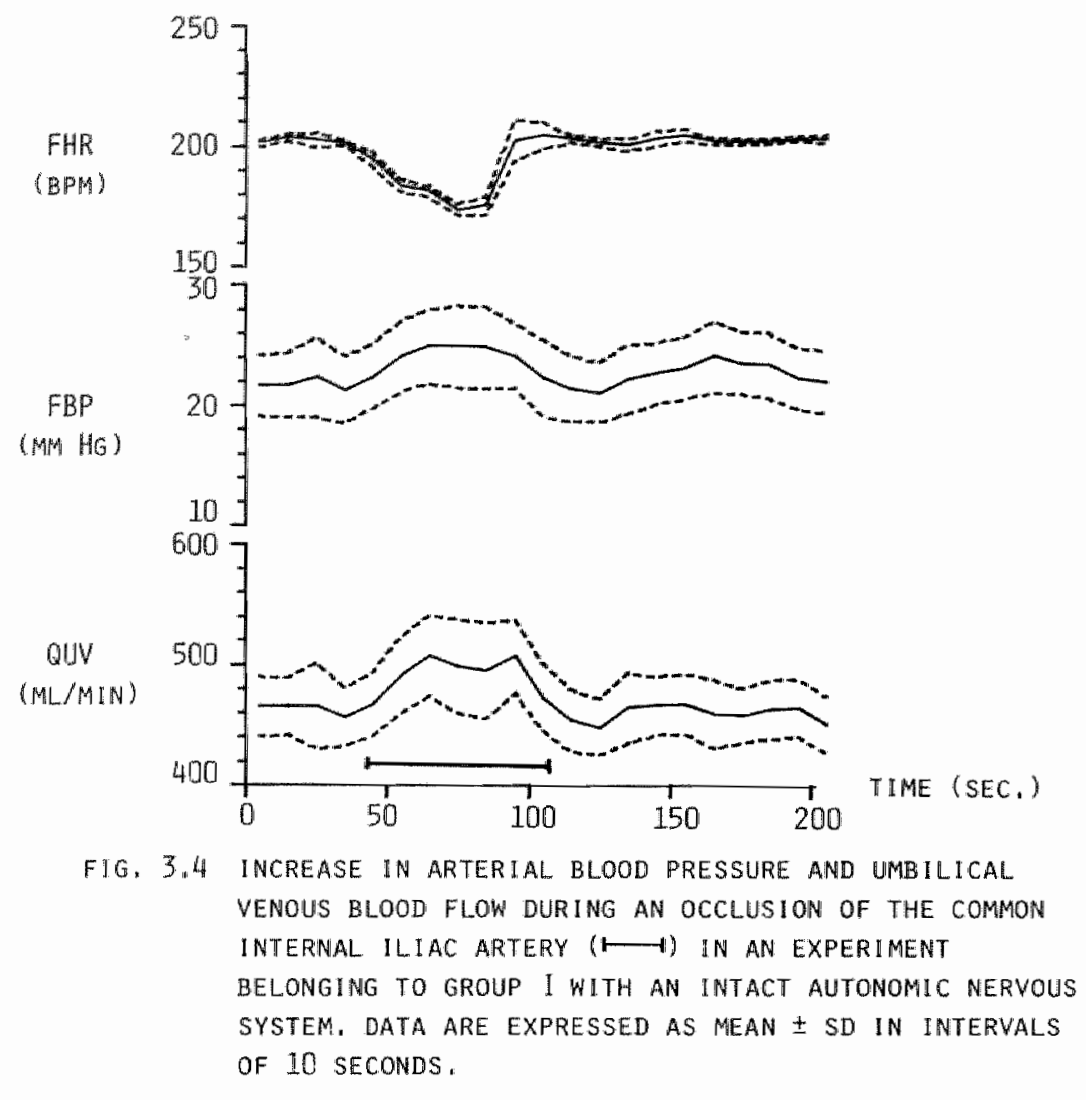

Umblilical venous blood flow showed the same reaction pattern as the changes in arterial pressure. If arterial blood pressure increased during the occlusion then umbillcal blood flow elther did not change or also increased. A marked decrease in umbllical blood flow was found however when arterlal blood pressure decreased.

A typlcal recording of the cardlovascular parameters during an occlusion, showing a decrease in arterial blood pressure and umbllical blood flow is shown in fig. 3.6 . 


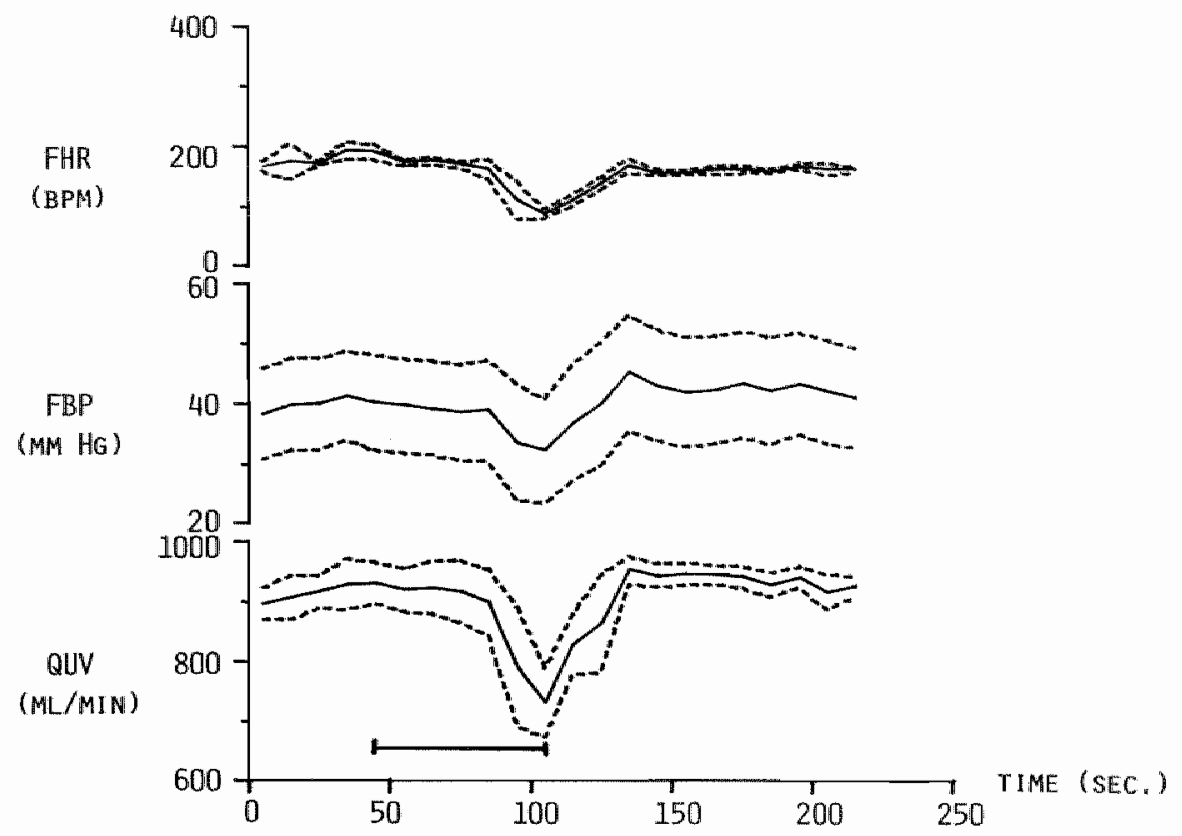

FIG. 3.5 DECREASE IN ARTERIAL BLOOD PRESSURE AND UMBILICAL VENOUS BLOOD FLOW DURING AN DCCLUSIION OF THE COMMON INTERNAL ILIAC ARTERY ( BELONGING TO GROUP II WITH AN INTACT AUTONOMIC NERVOUS SYSTEM. DATA ARE EXPRESSED AS MEAN \pm SD IN INTERVALS OF 10 SECONDS. 


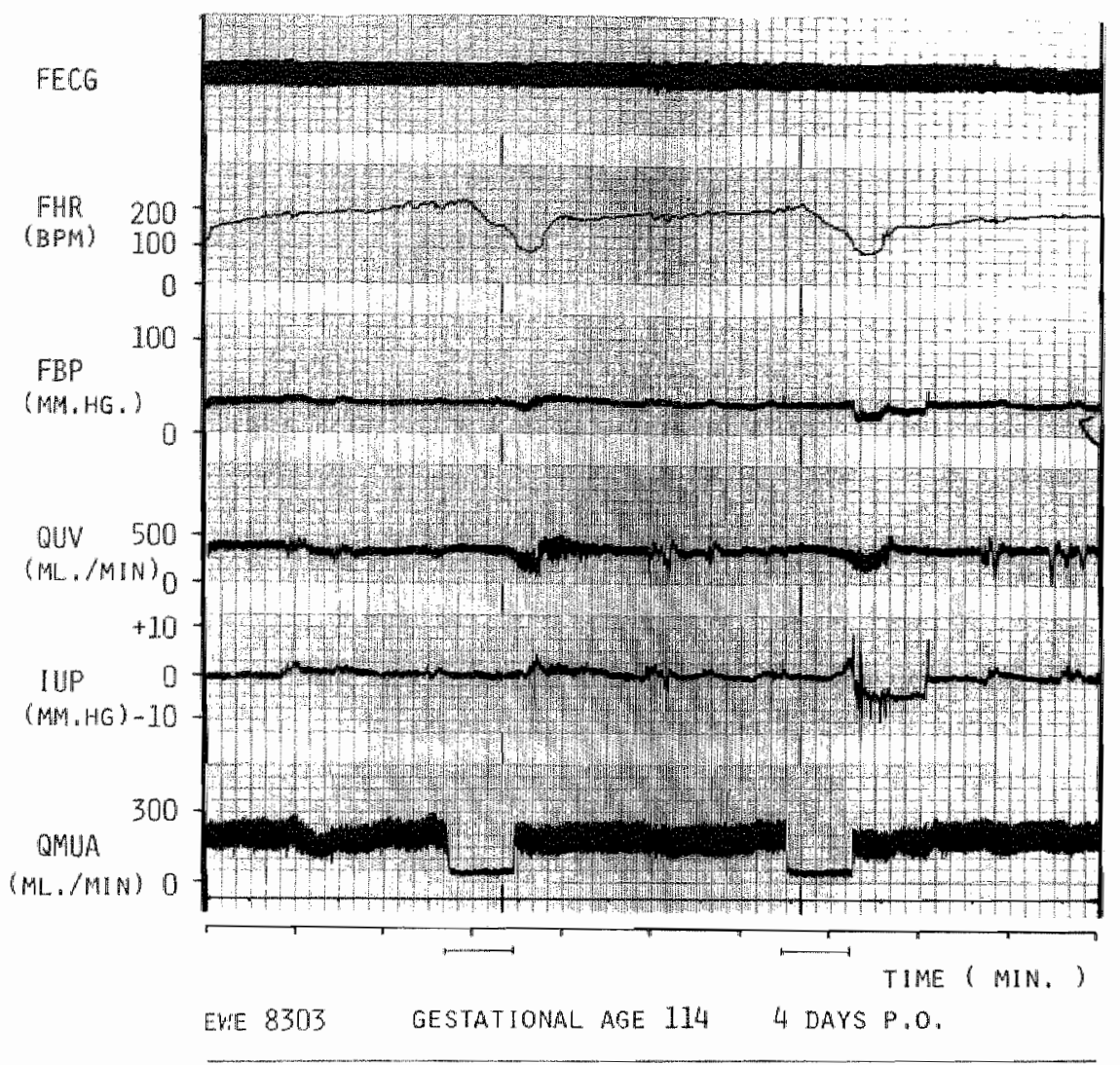

FIG. 3.6 DECREASE N UMBILICAL WENOUS BLOOD FLOW AND ARTERIAL BLOOD PRESSLIRE DURING AN OCCLUSION OF THE COMMON INTERNAL ILIAC ARTERY ( $\rightarrow$ IN A FETUS WITH AN INTACT AUTONOMIC NERYOUS SYSTEM. 
The fetal acid-base balance in the control perlod and imnediately after the last occlusion in that particular serles of experiments in which mean arterlal blood pressure Invariably increased during the occlusions is shown in table 3.3. The same data are given in table 3.4 for the group experiments in which mean arterial blood pressure decreased. The fetuses from group II had a higher starting and ending $\mathrm{pH}$ and $\mathrm{pO}_{2}$ value than the fetuses from group $I$. The starting and ending $\mathrm{pCO}_{2}$ value was higher in group I than in group II.

\begin{tabular}{|c|c|c|c|c|}
\hline & 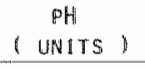 & $\begin{array}{r}\mathrm{PO}_{2} \\
(\mathrm{KPA}) \\
\end{array}$ & 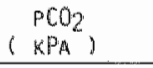 & $\left(\begin{array}{ll}B E \\
\left(B O / L_{\text {in }}\right)\end{array}\right.$ \\
\hline CONTROL PERIOD ( $N=10)$ & $7.34 \pm 0.03$ & $2,81 \pm 0,81$ & $5.44+0.65$ & $-3,6 t: 1,5$ \\
\hline $\begin{array}{r}\text { AFTER THE LASTT OCCLUSION } \\
\text { ( } N=7)\end{array}$ & $7.29 \pm 0.03$ & $2.49+0,81$ & $5.83 \pm 0.83$ & $-5,5 \pm 1,6$ \\
\hline
\end{tabular}

TABLE 3.3 FETAL ACID-BASE BALANCE DURING THE CONTROL PERIOD AND IMHEDIATELY AFTER THE LAST OCCLUSION OF THE COMMON INTERNAL ILIAC ARTERY IN THE SERIES OF EXPERIMENTS IN WHICH ARTERIAL BLOOD PRESSURE INCREASED AT THE END OF THE OCCLUSIOH (GROUP I).

\begin{tabular}{|c|c|c|c|c|}
\hline & $\begin{array}{l}\text { PH } \\
\text { UNITS }\end{array}$ & $\left(\begin{array}{l}\mathrm{PO}_{2} \\
\mathrm{KPA}\end{array}\right)$ & $\left(\mathrm{KPA}_{2} \mathrm{PCO}_{2}\right.$ & $(\mathrm{BE})$ \\
\hline CONTROL $(N=10)$ & $7.37+0.02$ & $3.90 \pm 0.76$ & $4.84 \pm 0.62$ & $-2,7 \pm 1,2$ \\
\hline $\begin{array}{c}\text { AFTER THE LAST OCCLUSIDH } \\
\left(* \mathrm{~N}^{2}=7\right)\end{array}$ & $7.34 \pm 0,03$ & $3.29 \pm 0.65$ & $5.24 \pm 0.79$ & $-4,5 \pm 1,3$ \\
\hline
\end{tabular}

TABLE 3.4 FETAL ACID-BASE BALANCE DURLING THE CONTROL PERIOD AND IMMEDIATELY AFTER THE LAST OCCLUSION OF THE COMMON INTERNAL ILIAC ARTERY IN THE SERIES OF EXPERIMENTS IH WHICH ARTERIAL BLOOD PRES SURE DECREASED AT THE END OF THE OCCLUSHOH (GROUP II), 
Table 3.5 mows the data on gestational age, and number of days arter surgery at the time of the occlusion experiment and the duration of the occlusion for group I.

\begin{tabular}{lrc}
\hline GROUP $\mathbb{I}$ & MEAM \pm SD & RANGE \\
\hline GESTATIONAL AGE (DAYS) & $119.3 \pm 2.7$ & $110-138$ \\
TIME AFTER SURGERY(DAYS) & $10 \pm 2.7$ & $3-28$ \\
OCCLUSION TIME ( SECONDS) & $78 \pm 6.6$ & $30-200$ \\
\hline
\end{tabular}

TABLE 3.5 GESTATIOHAL AGE, TIME AFTER SURGERY AND OCCLUSION TIME OF THE 36 OCCLUSIONS OF THE COMMON INTERNAL ILINC ARTERY, PERFORMED IN 8 ANIMALS IN GROUP I.

A composite analysis of the data on fetal heart rate, arterlal blood pressure and umbllical venous blood flow from group $I(n=36)$ is given $\ln \mathrm{flg} \cdot 3.7$.

The double vertical. bars between control and end of the occlusion values represent the varlation in occlusion time.

Fetal heart rate was slgniflcantly $(\mathrm{p}<0.001)$ reduced from the control value with $25.2 \%$ by the end of the occlusion (179 to $134 \mathrm{bpm}$ ). After the end of the pcclusion fetal heart rate gradually returned towards the control level. There was a slgnificant reduction (p<0.001) at 10 , 30 and 60 seconds after the occlusion of respectively $21.7 \%, 12.8 \%$ and $5.6 \%$.

Two minutes after the occlusion fetal heart rate was $169 \mathrm{bpm}$, which was st111 signiflcantly ( $p<0.05)$ lower than the control value of 179 bpo. Fetal arterlal bload pressure was slgniflcantly increased (p<0.001) with $5.7 \%(40.3 \mathrm{~mm} \mathrm{Hg}$ ) above the control value $(38.1 \mathrm{~mm} \mathrm{Hg})$ at the end 

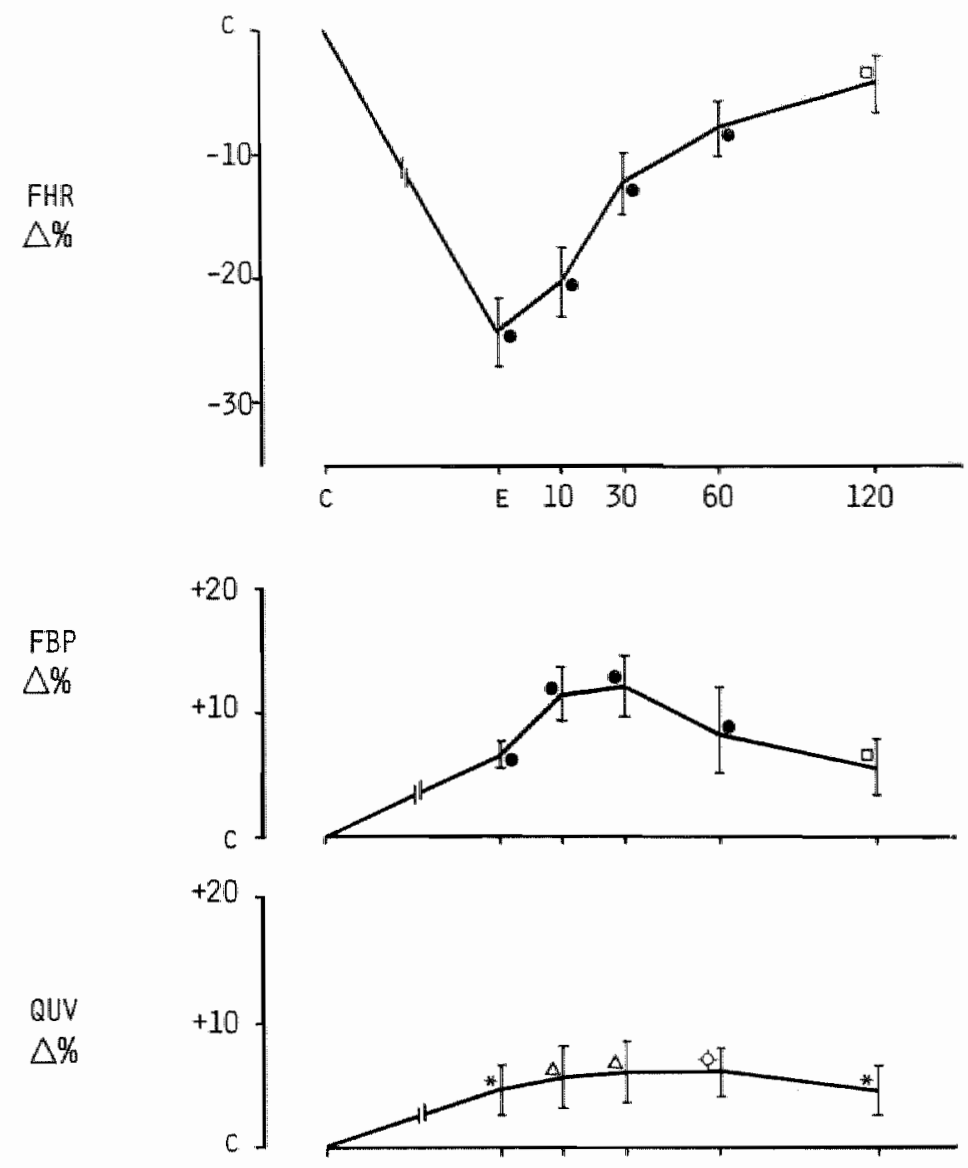

$\bullet<<0.001 \quad \Delta P<0.01 \quad \square P<0.05 \quad$ oP $<0.005 \quad * P<0.02$

$\mathrm{F} 1 \mathrm{G} 3.7$

A COMPOSITE ANALYSIS OF THE CHANGES IN FETAL HEART RATE, ARTERIAL BLOOD PRESSURE AND UMBILICAL VENOUS BLOOD FLOW DURING AND AFTER THE OCCLUSION OF THE COMMON INTERMAL ILIAC ARTERY IN GROLP I WITH INTACT AUTONOMIC NERVOUS SYSTEM. THE VERTICAL BARS BETWEEN C AND E REPRESENT THE VARIATION IN OCCLUSION TIME. 
of the occlusion. Artertal blood pressure rose further to reach its maximum increase (11.8\%) at 30 seconds after the end of the occlusion ( $p<0.001$ ). Thereafter a gradually returning of blood pressure towards control level occurred but it still was slgnificantly higher (4.7\%) than control level at two minutes after the end of the occlusion $(\mathrm{p}<0.05)$.

Unbilical blood flow paralelled with the increase in arterial blood pressure.

Umbilical blood flow was signiflcantly higher ( $408 \mathrm{ml} / \mathrm{min} ; \mathrm{p}<0.02$ ) at the end of the occlusion with an increase of $4.6 \%$ above the control value $(390 \mathrm{ml} / \mathrm{min})$. The maximum blood flow increase $(5.9 \% ; \mathrm{p}<0.01)$ was also found at 60 seconds after the occlusion. At two minutes umblical blood flow was still significantly higher $(p<0.02)$ than the control value.

Table 3.6 shows the data on gestational age and number of days after surgery at the time of the occlusion experiment and the duration of the occlusion for group II.

\begin{tabular}{lrr}
\hline GROUP II & MEAN \pm SD & \multicolumn{1}{c}{ RANGE } \\
\hline GESTATIONAL AGE ( DAYS ) & $116.2 \pm 2.3$ & $110-136$ \\
TIME AFTER SURTERY (DAYS) & $6.7 \pm 2.2$ & $3-26$ \\
OCCLUSION TIHE ( SECONDS ) & $68 \pm 5.7$ & $30-180$ \\
\hline
\end{tabular}

TABLE 3.6 GESTATIONAL AGE, TIME AFTER SURGERY AND OCCLUSION TIME OF THE 33 OCCLUSIONS OF THE COMMON INTERNAL ILIAC ARTERY, PERFORNED IN 7 ANHMALS IN GROUP IJ. 
A composite analysis of the data on fetal heart rate, arterial blood pressure and umbilical venous blood flow from group II $(n=33)$ is given in flig. 3.8. The double vertical bars between control and end of the occlusion values represent the variation in occlusion time.

The reduction in fetal heart rate was greater than in group $I$.

Fetal heart rate fell to $63.8 \%$ (113 bpm) from the control value (177 bpm) at the end of the occlusion, whtch decrease was highly signiflcant (p<0.001).

The return of fetal heart rate towards control level was slower than in group I with a significant decrease $(p<0.001)$ of respectively $27.1 \%$, $14.1 \%, 10.1 \%$ and $6.8 \%$ at $10,30,60$ and 120 seconds after the end of the occlusion.

Fetal arterlal blood pressure showed in contrast to the changes in group one a decrease which was maximal at the end of the occlusion time. Blood pressure was at that time slgntflcantly $(p<0.001)$ diminished to $90.8 \%(35.6 \mathrm{~mm} \mathrm{Hg})$ of the control value $(39.2 \mathrm{~mm} \mathrm{Hg})$. Blood pressure had already returned to nearly the control value at 10 seconds from the end of occlusion. At 30 and 60 seconds after the occlusion blood pressure was increased w1th $3.1 \%$ resp. $3.5 \%$ above control value. These changes were not significant. At 2 minutes after the occlusion no difference from the control level was found. Umb1lical venous blood flow also slgnificantly $(p<0.001)$ decreased in this group with $10.7 \%$ from $466 \mathrm{ml} / \mathrm{min}$ at control perlod to $417 \mathrm{ml} / \mathrm{min}$ at the end of the acclusion.

Umbilical blood fllow was still significantly (p<0.02) decreased at 10 seconds post occlusion w1th $5.4 \%$. There after no slgnificant difference from the control value was present. 


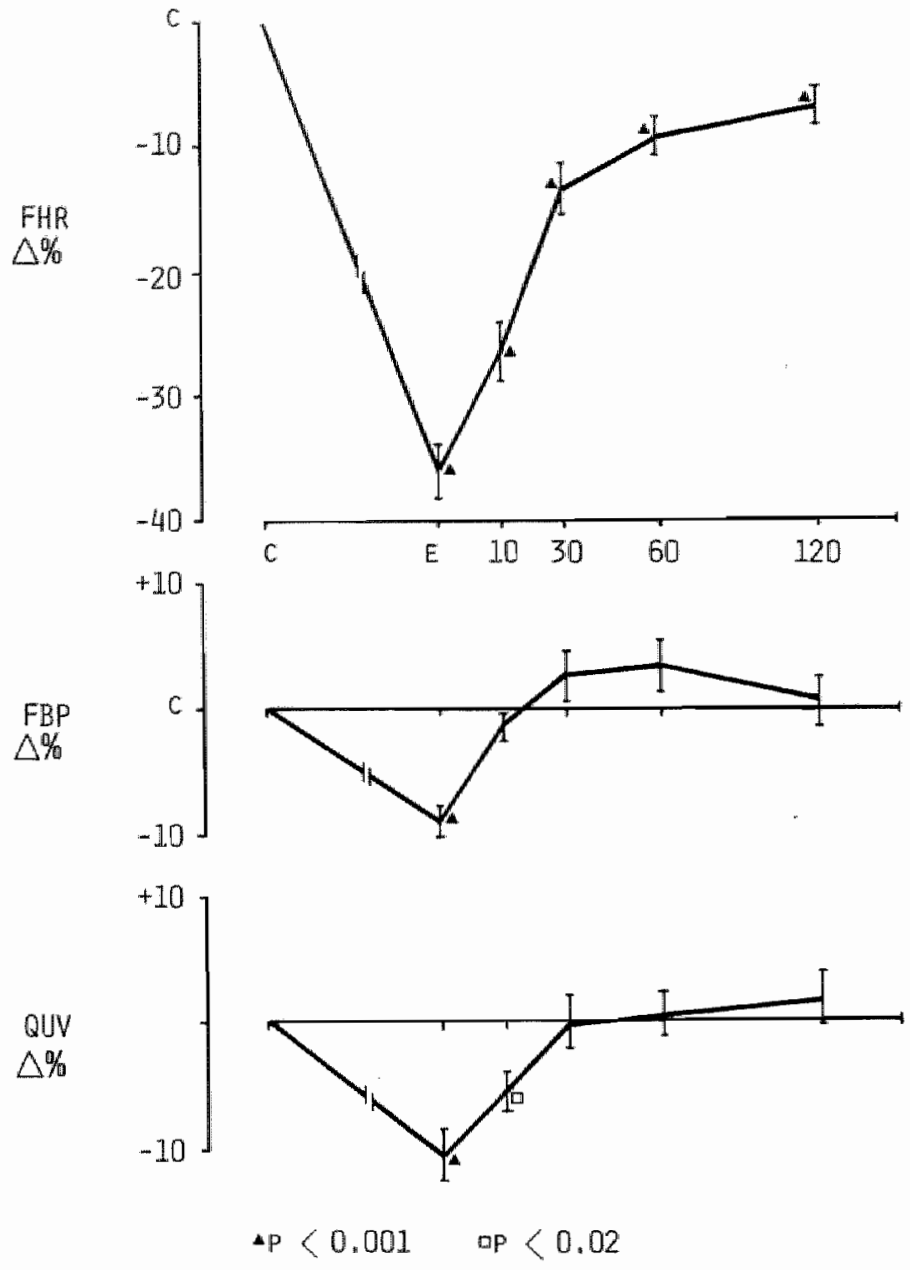

FIG.3.8 A COMPOSITE ANALYSIS OF THE CHANGES IM FETAL HEART RATE, ARTERIAL BLOOD PRESSURE AND UMBILICAL VENOUS BLOOD FLOW DURING AND AFTER THE OCCLUSION OF THE COMMON INTERNAL ILIAC ARTERY IN GROUP II HITH INTACT AUTONOMIC NERVOUS SYSTEM. THE WERTICAL BARS BETWEEN C AND E REPRESENT THE WARIATION IN OCCLUSION TIME, 
3.5.3 Selective blockade of a part of the autonomic nervous system

The data of each series of occlusions after respectively cholinergic, alpha-adrenergic and beta-adrenergic blockade were analysed as total group and in two subgroups.

Before the occlusions during autonomic blockade were perfomed, one to three "control" occlusions without blockade were performed. The data of the occlusions after autonomic blockade were pooled in subgroup i, if the foregoing "control" occlusions had led to an increase in mean arterial blood pressure at the end of the occlusion and in subgroup 2 If on the contrary a decrease in mean arterlal blood pressure had occurred during the "control" occlusions.

Statistical analysis was done by means of Wilcoxon's matched-pairs signed-ranks test. All p-values were calculated for two talled tests. Data are expressed in the composite analyses as percent change \pm SEM from control as $100 \%$ reference level. The occlusion time in the experiments during autonomic blockade was in the same order of magnitude as with the "control" occlusions except after propranolol, in which case of ten a longer occlusion was necessary to establish heart rate changes. 


\subsubsection{Cholinergic blockade w1th atropine}

The data on gestational age and number of days after surgery at the time of the experiment and the duration of the occlusion for the total group are deplcted in table 3.7 .

\begin{tabular}{lcr}
\hline CHOLINERGIC BLOCKADE & MEAN \pm SD & \multicolumn{1}{l}{ RANGE } \\
\hline GESTATIONAL AGE ( DAYS) & $118.5 \pm 2.1$ & $114-130$ \\
TIME AFTER SURGERY (DAYS) & $5.5 \pm 2.1$ & $3-19$ \\
OCCLUSION TIME ( SECONDS) & $78 \pm 4.8$ & $30-120$ \\
\hline
\end{tabular}

TABLE 3.7 GESTATIONAL AGE, TIME AFTER SURGERY AND OCCLUSION TIME OF THE 17 OCCLUSIONS OF THE COMMON INTERNIAL ILIAC ARTERY, PERFORMED IN 6 ANIMALS AFTER CHOLINERGIC BLOCKADE.

F1g. 3.9 shows a typical recording of an occlusion response after atropine administration: no decrease in heart rate and an increase in arterial blood pressure and umblilcal venous blood flow. Mean values \pm SD of fetal heart rate, arterial blood pressure and umbilical venous blood flow in a single occlusion experiment are given in $\mathrm{fig} .3 .10$. A composite analysis of the data on fetal heart rate, arterial blood pressure and umbllical venous blood flow from the total group of occlustons during cholinergic blockade is given in fig. 3.11 .

An increase in fetal heart rate of $7.7 \%$ from 209 bpm to 225 bpm was seen at the end of the occlusion $(p<0.02)$, followed by the maximum response $(9.1 \%)$ at 10 seconds after the occlusion $(p<0.05)$, after which a slow return towards control level occurred at two minutes.

Arterial blood pressure also Increased with a maxinum response of $9.2 \%$ (from 40.3 to $44 \mathrm{~mm} \mathrm{Hg}$ ) at the end of the occluston, after which a fast decrease to the control value was found at 2 minutes. 
FECG

FHR

(BPM)

\section{FBP}

$\left(M, H G\right.$. $\left.H G^{\prime}\right)$
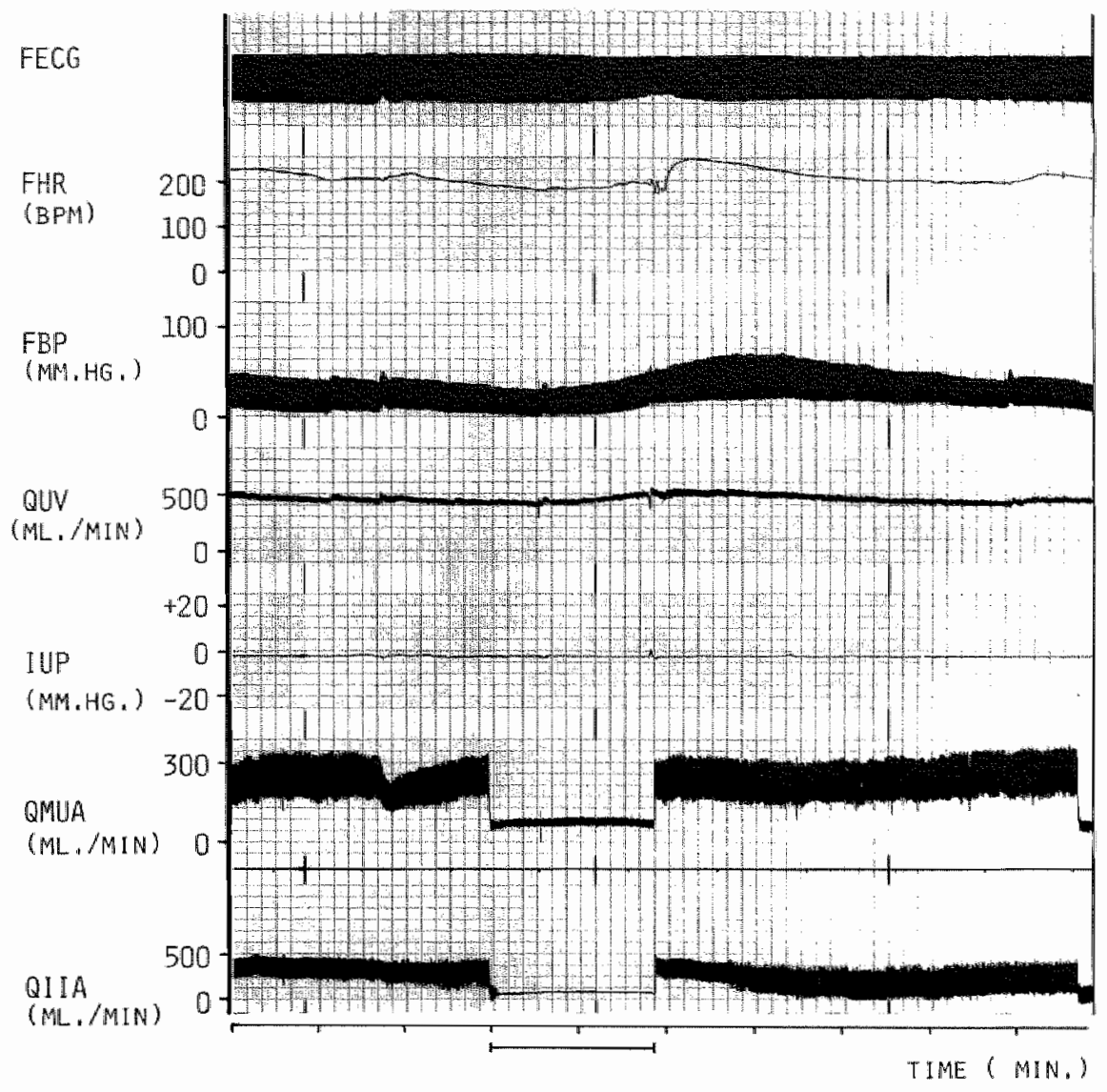

EWE 8308 GESTATIONAL AGE 120

4 DAYS P.O.

FIG. 3.9 CHANGES IN HEART RATE, ARTERIAL BLOOD PRESSURE AND UMBILICAL VENOUS BLOOD FLOW DURING AN OCCLUSION OF THE COMMON INTERNAL. ILIAC ARTERY $(\longrightarrow)$ AFTER CHOLINERGIC BLOCKADE WITH ATROPINE. 


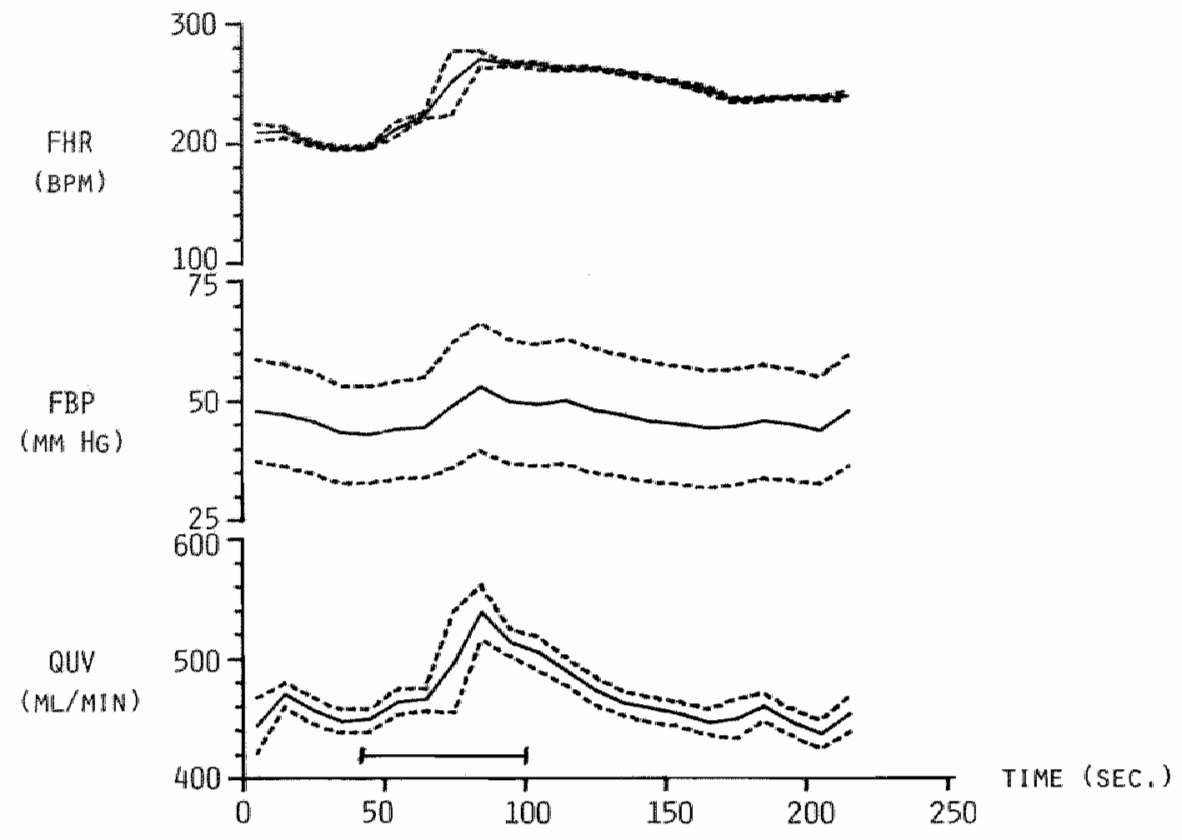

FIG, 3.10 THE CHANGES IN FETAL HEART RATE, ARTERIAL BLOOD PRESSURE AND UMBILICAL VENOUS BLOOD FLOW DURING AN OCCLUSION OF THE COMMON INTERNAL ILIAC ARTERY ( AFTER CHOLINERGIC BLOCKADE WITH ATROPINE. DATA ARE EXPRESSED AS MEAN \pm SD IN INTERVALS OF 10 SECONDS.

Umblifical venous blood flow followed the increase in heart rate and blood pressure with a slgniflcant increase ( $p<0.002$ ) of $9.6 \%$ from 503 $\mathrm{mil} / \mathrm{min}$ at control to $551 \mathrm{ml} / \mathrm{min}$ at the end of the occlusion. Umblilcal blood flow was also slgniflcant hlgher than the control value at 10 seconds post infusion. By 2 minutes umblilcal blood flow had completely returned to pre-occlusion values.

The composite analysis (fig. 3.12) of the fetal cardiovascular" parameters of subgroup 1 (5 occlusions in 3 animals) did not differ in general from that of the total group, except that only the increase in blood flow (8.6\%) was signiflcantly different from control (p<0.05). Thls $1 \mathrm{~s}$ probably due to the small number of observations $(5$ occlusions in 3 animals). 

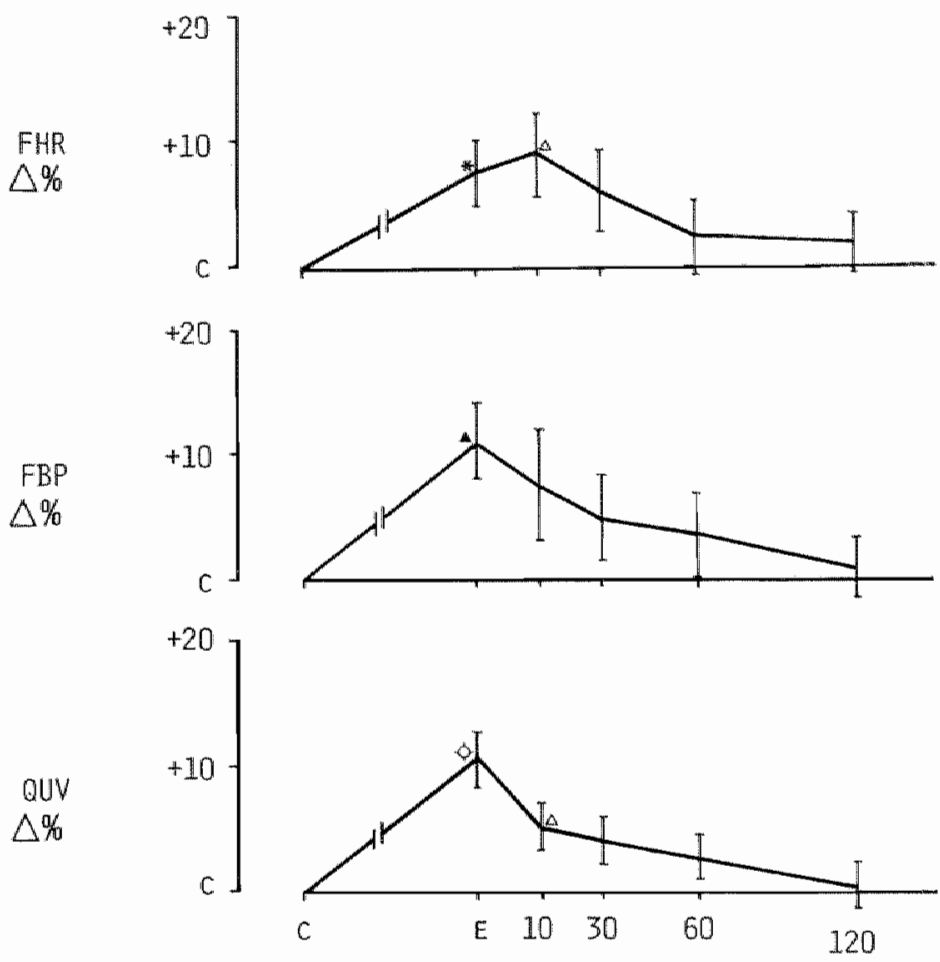

$* P<0.02 \quad 4 P<0.005 \quad p<<0.002 \quad \Delta p<0.05$

FIG 3.11 A COMPOSITE ANALYSIS OF THE CHANGES IN FETAL HEART RATE, ARTERIAL BLOOD PRESSURE AND UMBILICAL VENOUS BLOOD FLOW DURING AND AFTER THE OCCLUSION OF THE COMMON INTERNAL ILIAC ARTERY IN THE TOTAL SROUP OF OCCLUSIONS AFTER CHOLINERGIC BLOCKADE, THEE WERTICAL BARS BETWEEN C AND E REPRESENT THE VARIATION IN OCCLUSION TIME. 

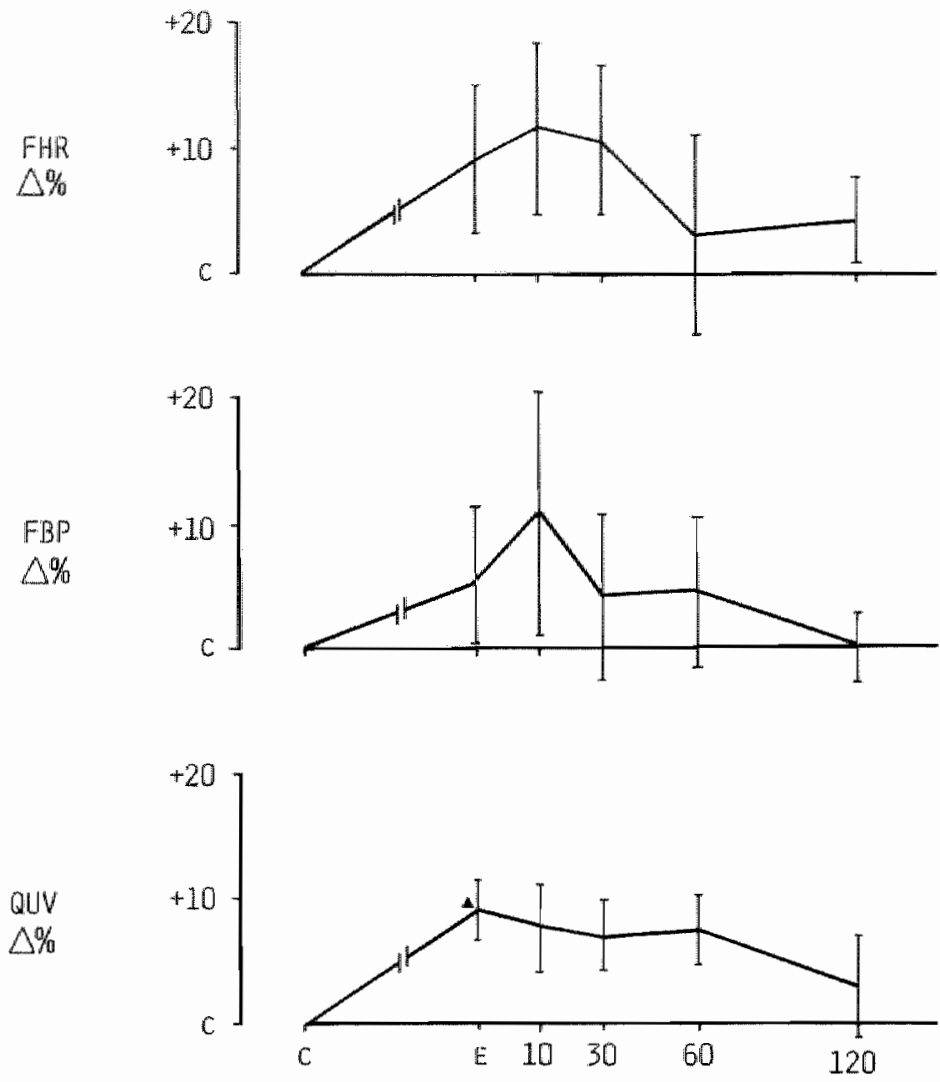

$\rightarrow p<0.05$

FIG 3.12 A COMPOSITE ANALYSIS OF THE CHANGES IN FETAL HEART RATE, ARTERIAL BLOOD PRESSURE AND UMBILICAL WENOUS BLOOD FLOW DURING AND AFTER THE OCCLUSION OF THE COMMON INTERNAL ILIAC ARTERY IN SUBGROUP [ WITH CHOLINERGIC BLOCKADE, THE VERTICAL BARS BETWEEN C AND E REPRESENT THE VARIATION IN OCCLUSION TIME. 

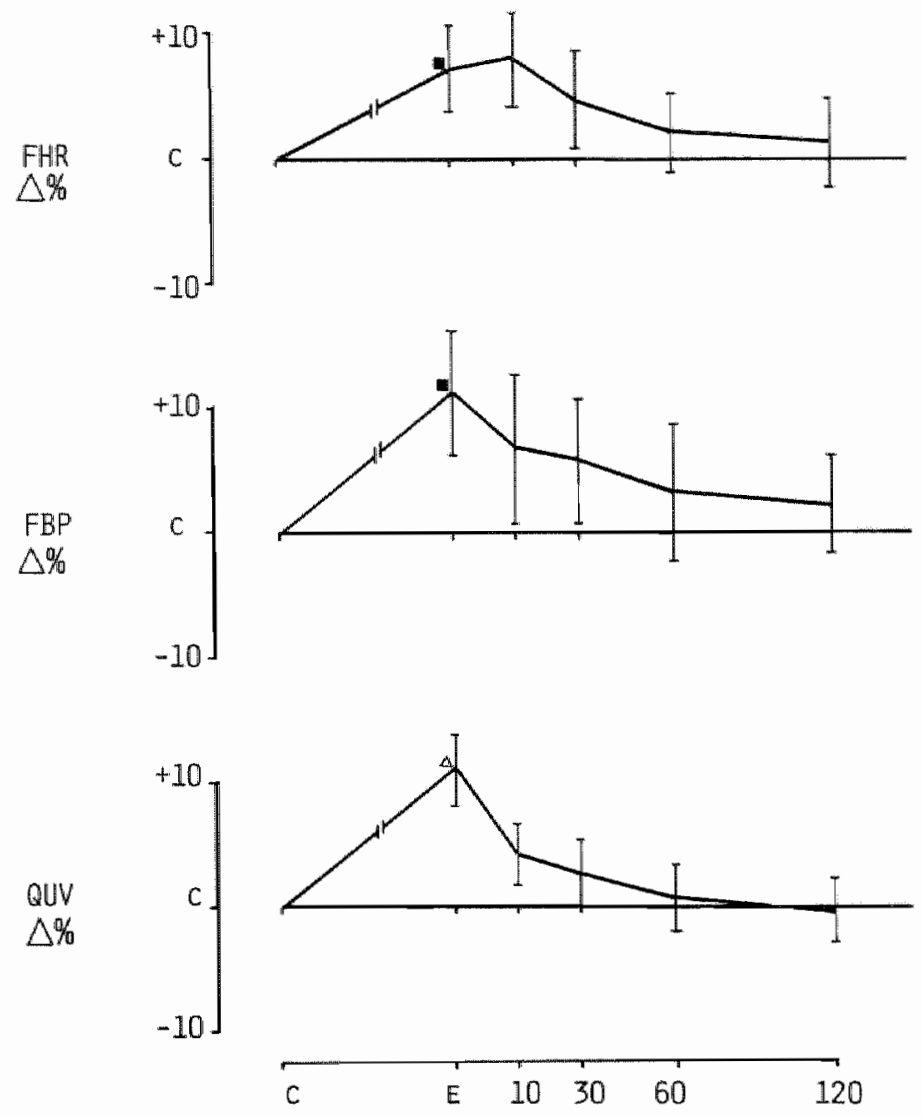

$\Delta p<0.01 \quad \Delta p<0.02$

FIG 3.13 A COMPOSITE ANALYSIS OF THE CHANGES IN FETAL HEART RATE, ARTERIAL BLOOD PRESSURE AND UMBILICAL. WENOUS BLOOD FLOW DURING AND AFTER. THE OCCLUSION OF THE COMMON INTERNAL ILIAC ARTERY IN SUBGROUP II WITH CHOLINERGIC BLOCKADE. THE VERTICAL BARS BETWEEN C AND E REPRESENT THE VARIATION IN OCCLUSION TIME. 
The same changes in fetal heart rate, arterlal blood pressure and umblilcal venous blood flow were also seen in subgroup 2 (12 occlusions in 4 animals). Both heart rate and blood pressure and also umbllical bloo flow Increased with a slgniflcant increase in heart rate of $6.9 \%$ (p<0.05), in blood pressure of 11.1\% (p<0.02) and in umblilcal blood low of $10.1 \%(p<0.01)$ at the end of the occlusion $(f 1 g .3 .13)$.

In 4 of the individual 12 occlusions of subgroup 2 still a deceleration In the heart rate was seen, although $1 t$ was small.

The increase in umblilcal blood flow was more prolonged in group I than In group II.

\subsubsection{Alpha-adrenergic blockade with phentolamine}

Table 3.8 shows the data on gestational age and number of days after surgery at the time of the experiment as well as the duration of the occlusion for the total group.

\begin{tabular}{lrr}
\hline ALPHA-ADRENERG IC BLOCKADE & MEAN \pm SD & RANGE \\
\hline GESTATIONAL AGE ( DAYS) & $117.9 \pm 2.3$ & $115-138$ \\
TIME AFTER SURGERY (DAYS) & $8.9 \pm 2.7$ & $3-28$ \\
OCCLUSION TIME ( SECONDS) & $106.8 \pm 7.9$ & $50-256$ \\
\hline
\end{tabular}

TABLE 3.8 GESTATIONAL AGE, TIHE AFTER SURGERY AND OCCLUSION TIME OF THE 19 OCCLUSIONS OF THE COMMON INTERMAL ILIAC ARTERY, PERFORMED IM 6 ANIMALS AFTER ALPHA-ADRENERGIC BLOCKADE.

The decrease in fetal heart rate upon interruption of the uterine blood supply after alpha-adrenergic blockade varıed in magnitude from very smal1 decreases in heart rate followed by accelerations to deep decelerations. Flgure 3.14 shows an example of a typlcal recording of a 
deep deceleration after alpha-adrenergtc blockade.

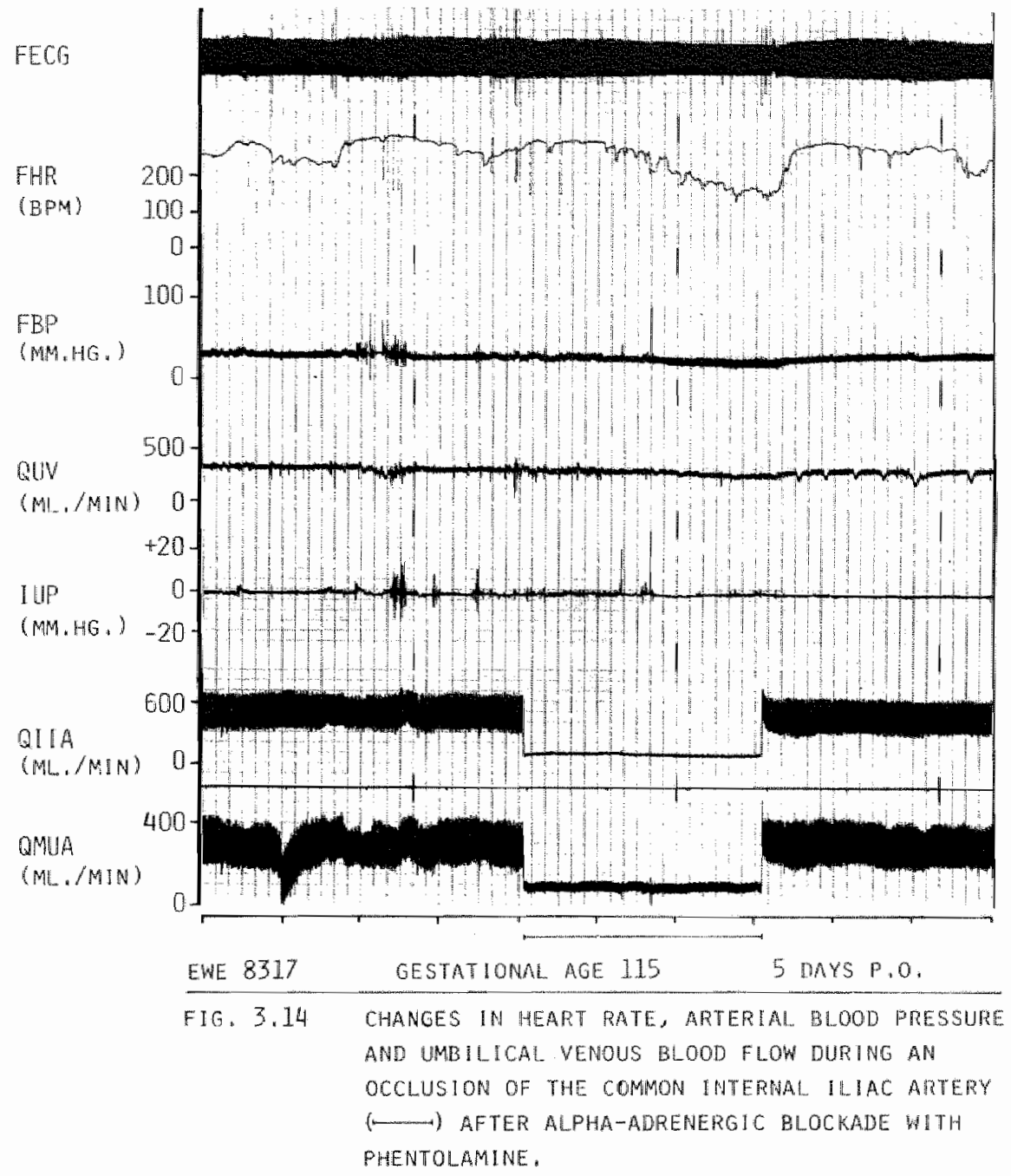


Figures 3.15 and 3.16 show the calculated neans \pm SD over intervals of 10 seconds in respectively an experiment without and with a deceleration ouring occlusion.

Fetal blood pressure decreased in all instances upon a comon internal I1lac artery occlusion.

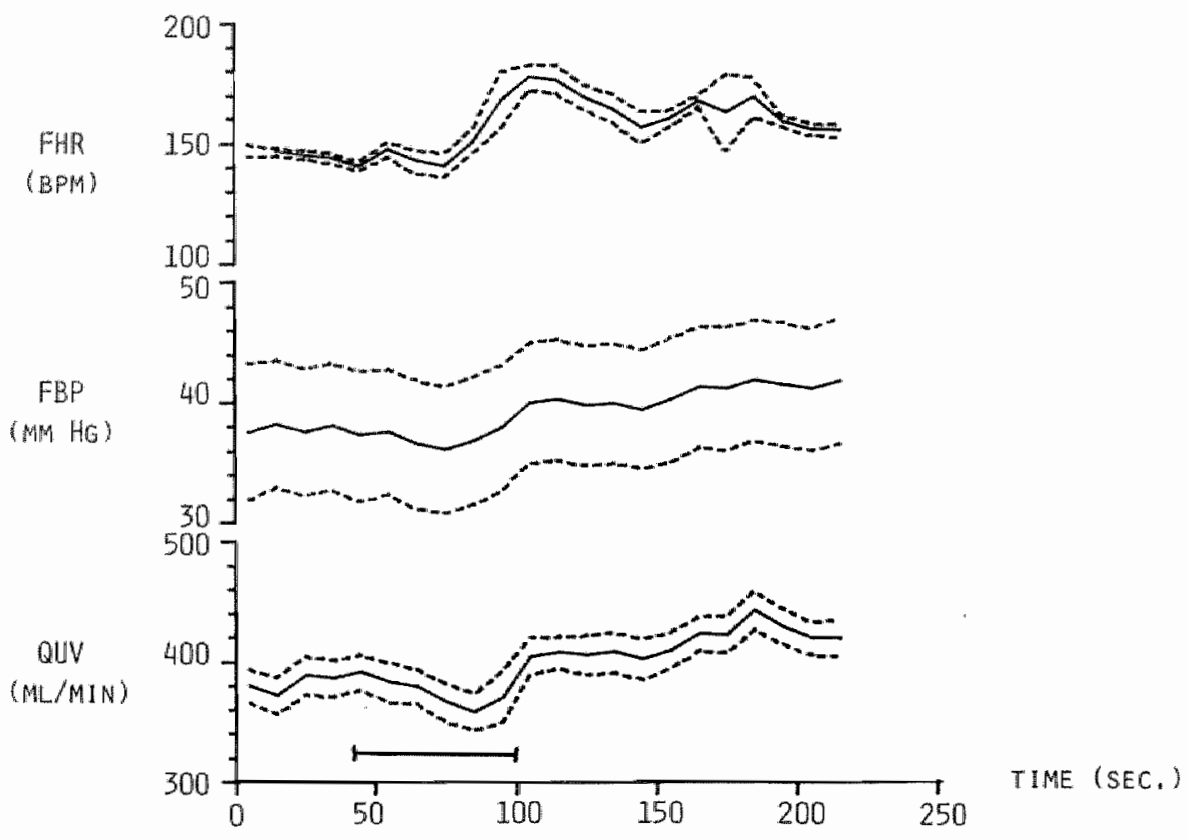

FIG. 3.15. THE ABSENCE OF A FETAL HEART RATE DECELERATION DURING OCCLUSION OF THE COMMON INTERNAL ILIAC ARTERY (い) AFTER PHENTOLAMINE ADMINISTRATION TO A FETUS OF GROUP 1. NOTE THE DECREASE IN BLOOD PRESSURE WITH THE CONCOMITANT FALL IN UMBILICAL BLOOD FLOW. DATA ARE EXPRESSED AS MEAN \pm SD IN INTERVALS OF 10 SECONDS.

A composite analysis of the fetal cardiovascular varlables of the total group of occluslons during alpha-adrenergic blockade is given in figure 3.17 .

Fetal heart rate decreased slgnificantly ( $<<0.01$ ) from 206 bpm to 169 bpm $(=82 \%$ of control) at the end of the occlusion after which a fast return occurred to the control value. 


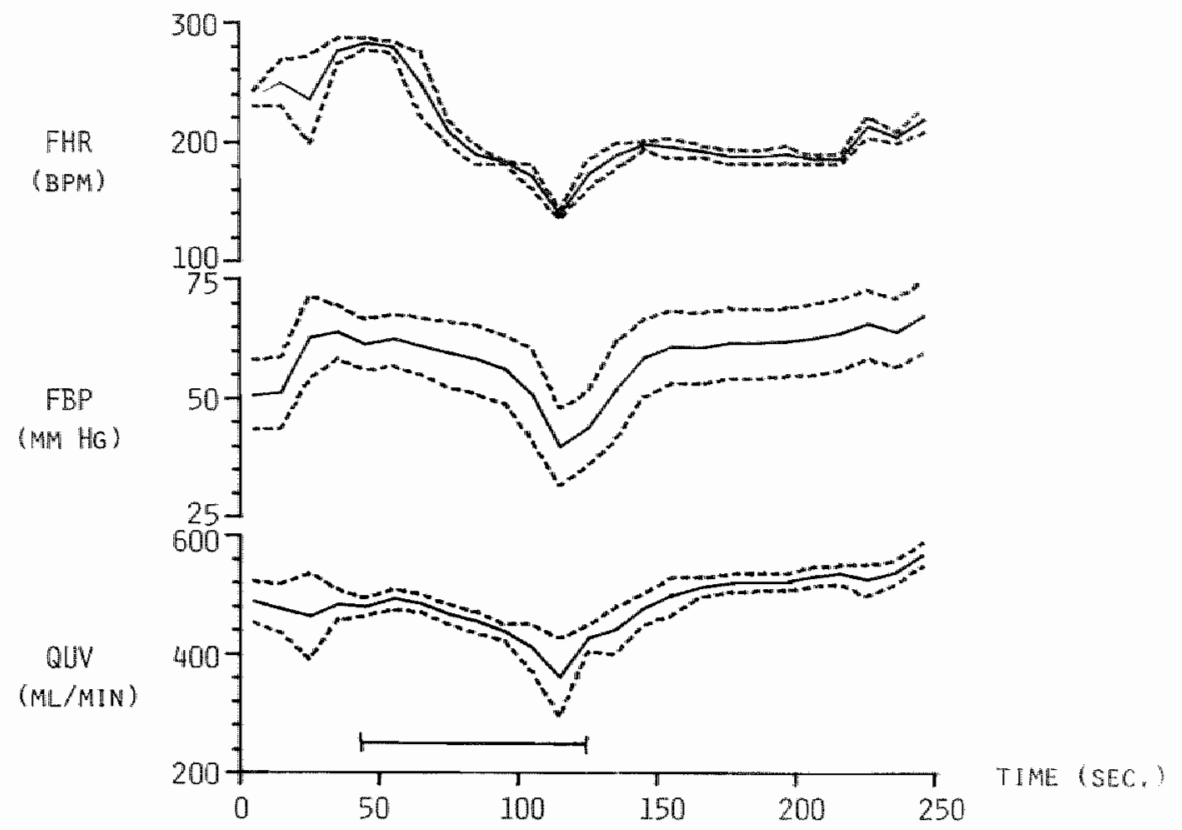

FIG, 3.16 A DECREASE IN FETAL. HEART RATE DURING AN OCCLUSION OF THE COMHON INTERNAL ILIAC ARTERY (- A) AFTER PHENTOLAMINE ADMINISTRATION TO A FETUS OF GROUP IL. NOTE THE DEEP FALL IN BLOOD PRESSURE AND UMBILICAL VENOUS BLOOD FLOW. DATA ARE EXPRESSED AS MEAN \pm SD IN INTERVALS OF IO SECONDS.

Arterlal blood pressure showed a marked decrease at the end of the occlusion from $39.6 \mathrm{~mm} \mathrm{Hg}$ to $34.2 \mathrm{~mm} \mathrm{Hg}(=86.4 \%$ of control), Pollowed by a slower return to and above the control value at two minutes. Umb11.1cal venous blood flow also decreased $(9.6 \%)$ with 1 ts nadir at the end of the occlusion, at which time blood flow had decreased from 458 $\mathrm{ml} / \mathrm{min}$ to $409 \mathrm{ml} / \mathrm{min}(\mathrm{p}<0.002)$.

At two minutes after the end of the occluslon umbll1cal blood flow was signiflcantly higher $(7.6 \%)$ than 1 tis control value $(p<0.01)$. 


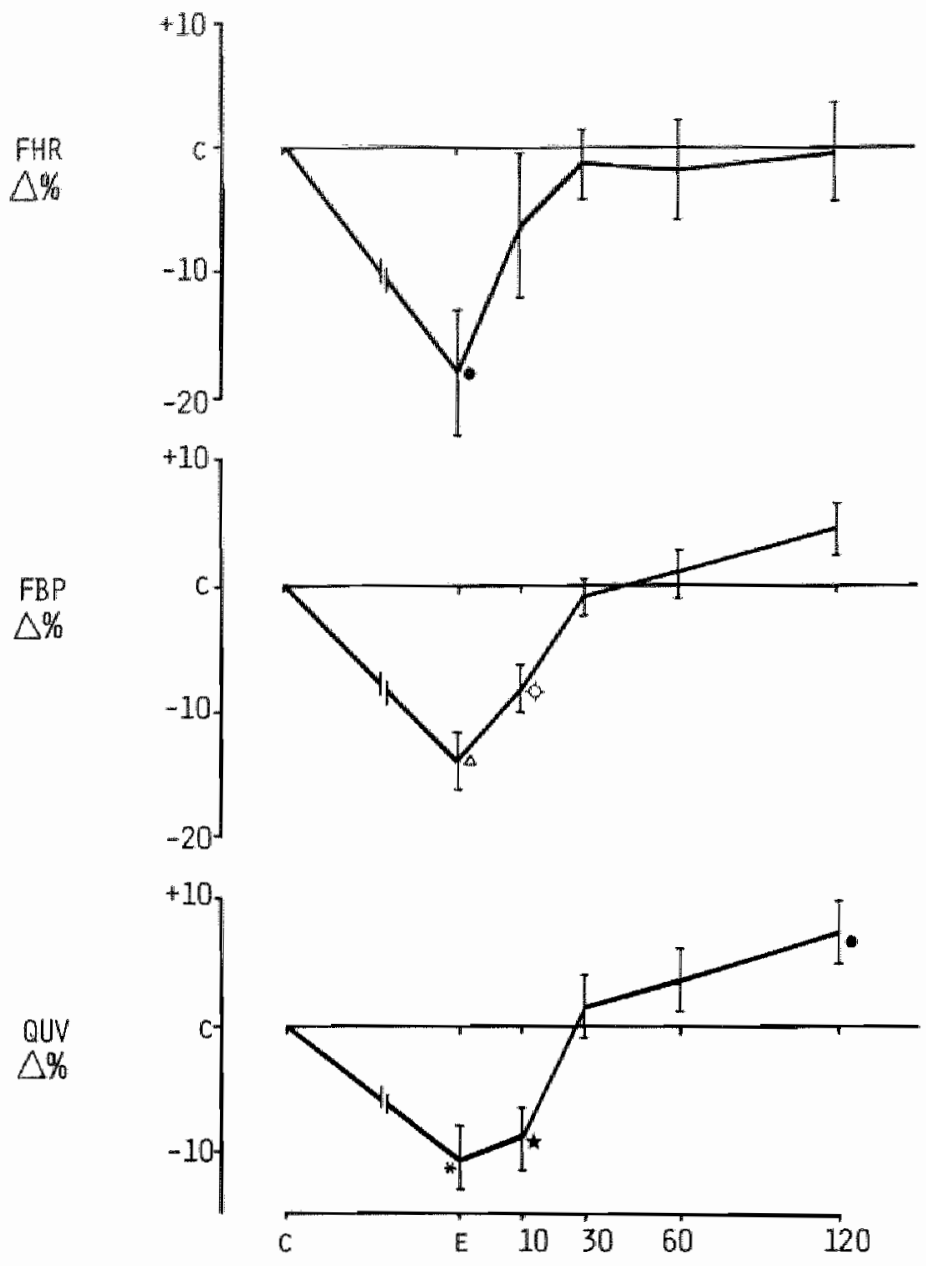

$\bullet P<0.01 \quad \Delta P<0.001 \quad \star P<0.05 \quad Q P<0.02 \quad * P<0.002$

FIG, 3,17 A COMPOSITE ANALYSIS OF THE CHANGES IN FETAL HEART RATE, ARTERIAL BLOOD PRESSURE AND UMBILICAL VENOUS BLOOD FLOW DURING AND AFTER THE OCCLUSION OF THE COMMON INTERNAL ILIAC ARTERY IN THE TOTAL GROUP OF OCCLUSIONS AFTEF ALPHA-ADRENERGIC BLOCKADE, THE VERTICAL BARS BETMEEN C AND E REPRESENT THE VARIATION IN DCCLUSION TIME. 
Dividing the total group into 1 ts two subgroups 1 and 2 according to the criteria summoned in paragraph 3.4 .3 revealed a remarkable alstinction between these two subgroups.

In subgroup 1 (10 occlusions in 3 animals) only a small decrease in heart rate was found at the end of the occlusion followed by a marked although not significant increase of $11.5 \%$ over control level at 10 seconds post occlusion, followed by a return to the control value at two minutes (fig. 3.18 ).

Arterlal biood pressure decreased and reached 1 ts nadir $(29.7 \mathrm{~mm} \mathrm{Hg}=$ $88.7 \%$ of the control value) at the end of the occlusion (p<0.01).

Blood pressure was slightly but not significantly elevated ower control level at two minutes post occlusion.

Umbllical venous blood flow showed only a silght but nonsigniricant decrease at the end of the occlusion after which a slight lncrease over control level followed parallel with the changes in heart rate and blood pressure (fig. 3.18).

Elgure 3.19 shows the composite analysis from the same cetal hemodynamic variables from subgroup 2 ( 9 occlusions in 3 animals). There is an obvious difference in magnitude of the changes between the two subgroups. The decrease in heart rate at the end of the occlusion is much greater in subgroup 2 than in subgroup 1 . Fetal heart rate decreased from $212 \mathrm{bpm}$ to $150 \mathrm{bpm}$ ( $=71 \%$ of control; $\mathrm{p}<0.01$ ) at the end of occlusion. Fetal heart rate was also significantliy $(\mathrm{p}<0.01)$ decreased at 10 seconds post occlusion, at which time an acceleration occurred in subgroup 1. At two minutes post occlusion the control. value had been reached again.

Fetal blood pressure decreased from $46.3 \mathrm{~m} \mathrm{Hg}$ to $39.1 \mathrm{~mm} \mathrm{Hg}$ ( $=84.4 \%$ of control) at the end of the occlusion $(p<0.02)$. A mall overshoot in pressure was seen at 2 minutes post occlusion.

Umbllical venous blood flow parallelled these pressure changes. The lowest flow value $(460 \mathrm{ml} / \mathrm{min}=84.0 \%$ of control; $\mathrm{p}<0.02)$ was recorded at the end of the occlusion followed by a rapid retum to control value at 30 seconds whereafter a slgnificant $(p<0.02)$ increase $(10.4 \%)$ in blood flow over control level was found at two minutes past occlusion. 


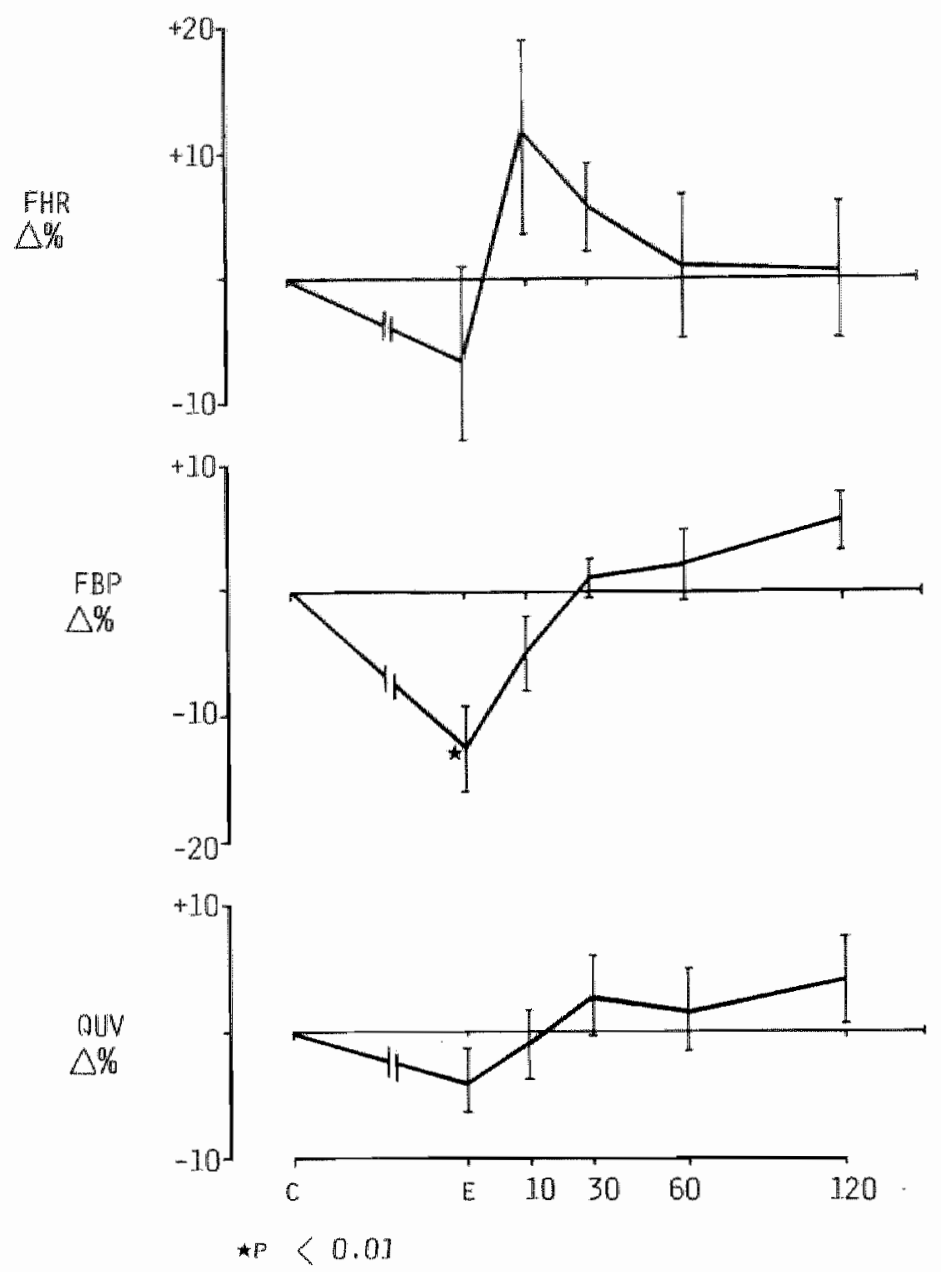

FIG. 3.18 A COMPOSITE ANALYSIS OF THE CHANGES IN FETAL. HEART RATE, ARTERIAL BLOOD PRESSURE AND UMBILICAL VENOUS BLOOD FLOW. DURING AND AFTER THE DCCLUSION OF THE COMMON INTERNAL ILIAC ARTERY IN SUBGROUP I WITH ALPHA-ADRENERGIC BLOCKADE THE VERTICAL BARS BETWEEN C AND E REPRESENT THE VARIATION IN OCCLUSION TIME. 
FHR

$\triangle \%$

$\triangle \mathrm{BP}^{\circ}$

Quv

$\triangle \%$
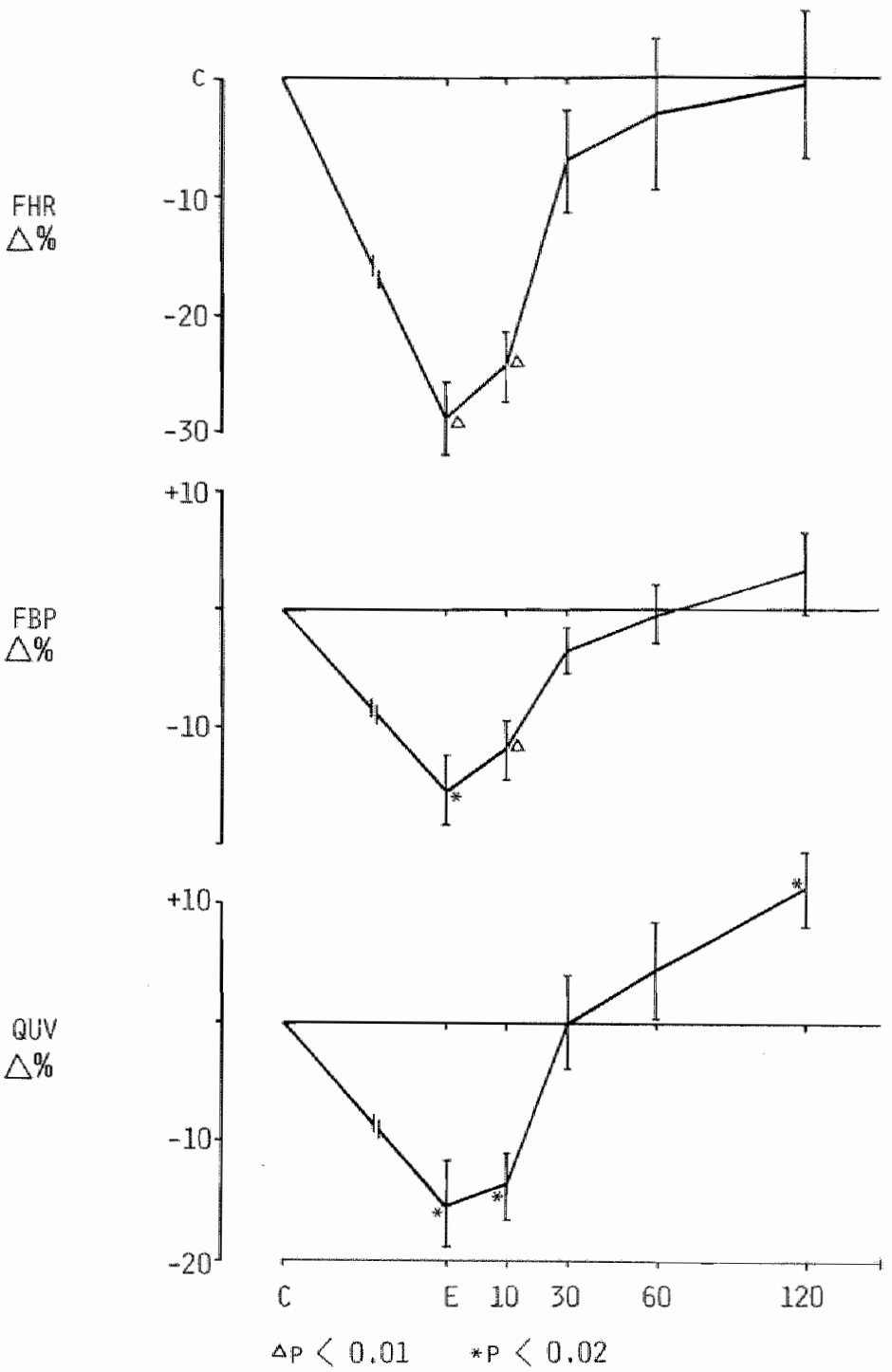

FIG 3.19 A COMPOSITE ANALYSIS OF THE CHANGES IN FETAL HEART RATE, ARTERIAL BLOOD PRESSURE AND UNBILICAL VENOUS BLDOD FLOW DURING AND AFTER THE OCCLUSION OF THE COMMON INTERNAL ILIAC ARTERY IN SUBGROUP II WITH ALPHA-ADRENERGIC BLOCKADE. THE VERTICAL BARS BETWEEN C AND E REPRESENT THE VARIATION IN OCCLUSION TIME. 


\subsubsection{Beta-adrenerg1c blockade w1th propranolol}

Table 3.9 whows the data on gestational age, number of days arter surgery at the time of the experiments as well as the duration of the occlusion time in the total group. The occlusion time in the propranolol group was longer than in the other groups for two reasons. F1r'stly the onset and the progress of the heart rate decrease was more gradual after beta-adrenergic blockade which made the early recognition of the deceleration during experimentation more difficult and secondly the ocelusions took place in animals in which in general a longer accluslon time was needed to establish any heart rate change ( $\mathrm{flg}$. $3.20)$

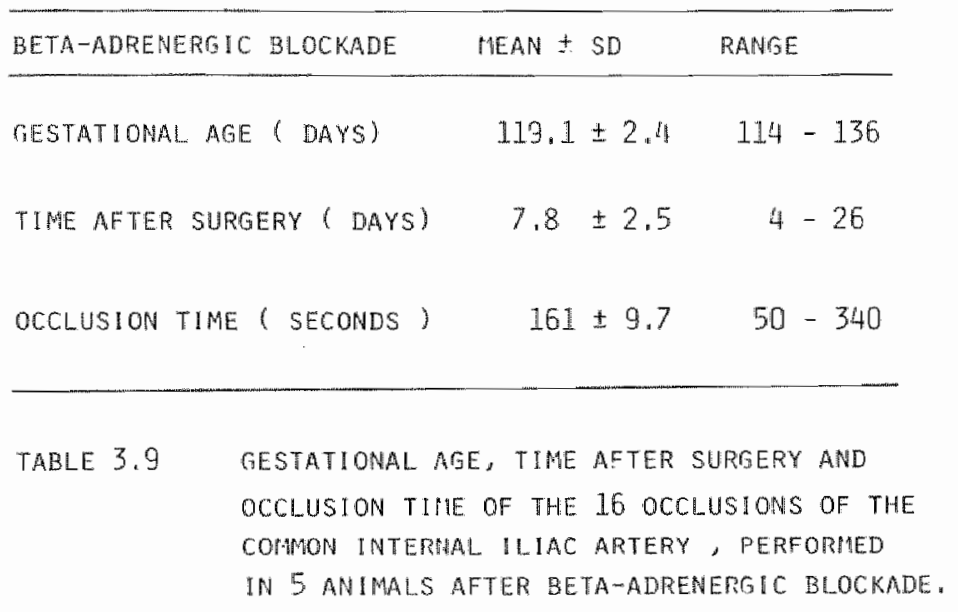

The composite analysis of the cardlovascular parameters of the total group of occlusions during beta-adrenergic blockade in fig. 3.21 show a maximum decrease in heart rate of $19.2 \%(p<0.002)$ at the end of the occluston (from 167 bpm to $136 \mathrm{bpm}$ ).

Blood pressure Increased from the end of the occlusion onwards to $a$ peak at 30 seconds $(6.5 \%$ tncrease above control from 40.1 to $42.8 \mathrm{~mm}$ $\mathrm{Hg} ; \mathrm{p}(0.02)$. 


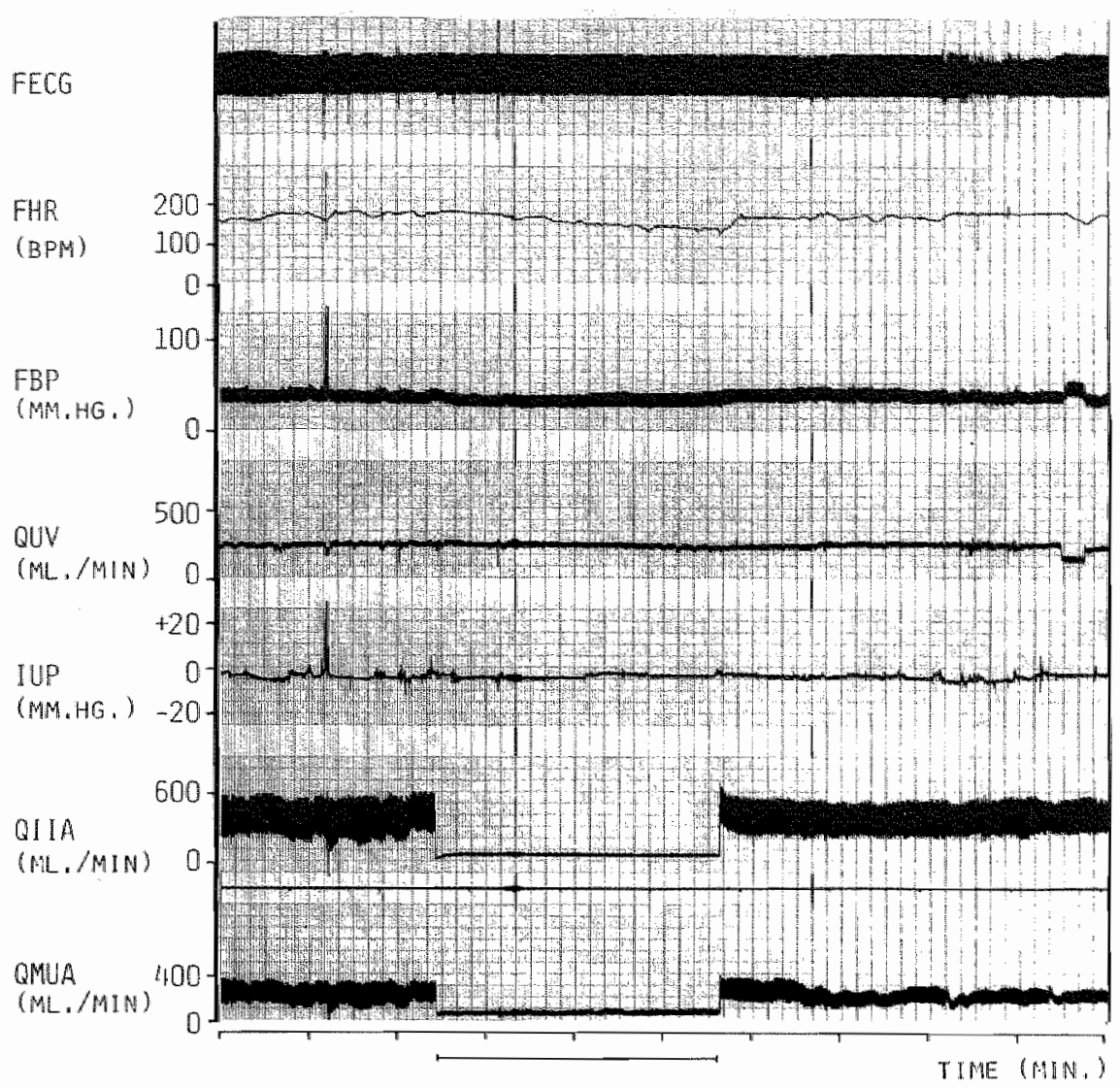

EWE 8317 GESTATIONAL AGE 114 LAYS P.O.

FIG, 3.20 A DISTINCT DECREASE IN HEART RATE DURING A PROLONGED OCCLUSION OF THE COMMON INTERNAL ILIAC ARTERY (り AFTER BETA-ADRENERGIC BLOCKADE HITH PROPRANOLOL. NOTE THE SLIGHT INCPEASE IH BLDOD PRESSURE AMD THE SMALL DECREASE IN UMBILICAL BLOOD FLOW AT THE END OF THE OCCLUSION" 


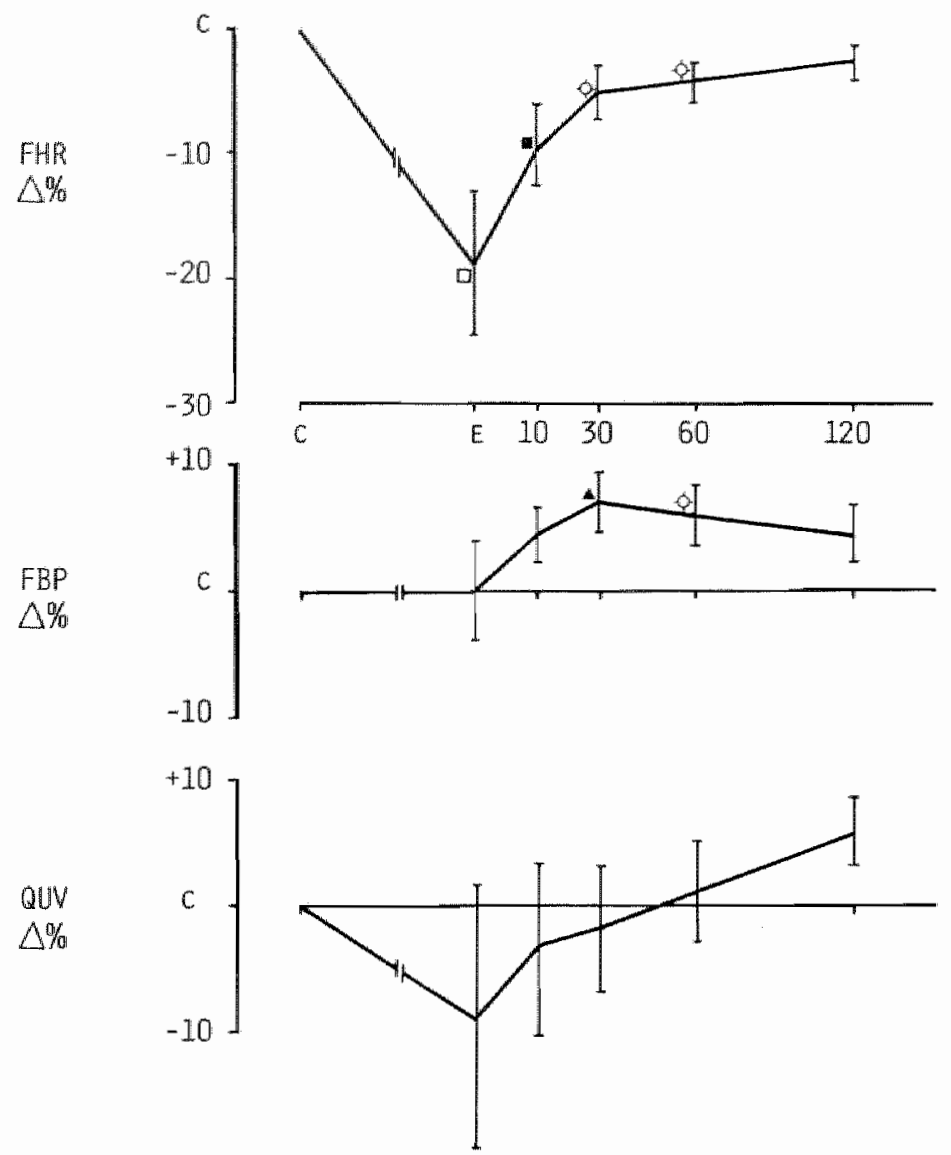

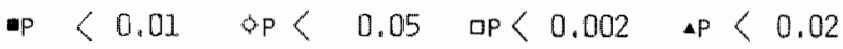

FIG 3.21. A COMPOSITE AMALYSIS OF THE CHANGES IN FETAL HEART RATE, ARTERIAL BLOOD PRESSURE AND UMBILICAL VENOUS BLOOD FLOW DUR!NG AND AFTER THE OCCLUSION OF THE COMMON INTERNAL ILIAC ARTERY IN THE TOTAL GROUP OF OCCLUSIONS AFTER BETA-ADRENERGIC BLOCKADE. THE VERTICAL BARS BETWEEN C AND E REPRESENT THE VARIATION IN OCCLUSION TIME. 
Umbilical venous blood flow was slightly decreased at the end of the occlusion, followed by a return to control value at 30 seconds and a small overshoot above control level at two minutes. The changes in umblilical venous blood flow reached no level of slgntflcance.
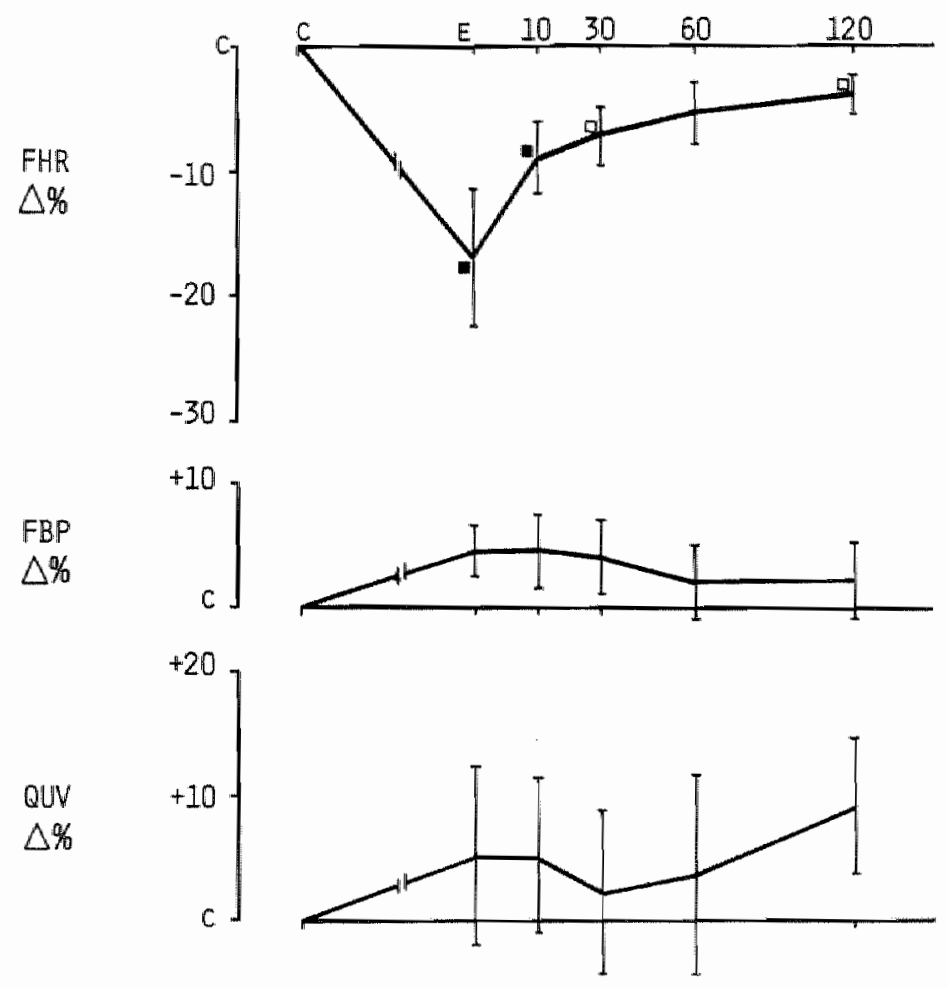

$\Delta<<0.02 \quad$ ap $<0.05$

FIG 3.22

A COMPOSITE ANALYSIS OF THE CHANGES IN FETAL HEART RATE, ARTERIAL BLOOD PRESSURE AND UMBILICAL VENOUS BLOOD FLOW' DURING AND AFTER THE OCCLUSION OF THE COMMON INTERNAL ILIAC ARTERY IN SUBGROUP I WITH BETA-ADRENERGIC BLOCKADE. THE VERTICAL BARS BETWEEN C AND E REPRESENT THE VARIATION IN OCCLUSION TIME, 
Agaln a diference was seen in the reaction pattems after dividing the total group in $1 \mathrm{tg}$ two subgroups 1 and 2 (f'ligures 3.22 and 3.23 ).

Subgroup 1 (8 occlusions in 4 animals) reacted with a deceleration in heart rate and an incease in both arterial blood presisure and umbllical bilood flow.

The fetal heart rate changes were slgniflcant at the p<0.02 level at the end of the occluston and at 10 seconds post occlusion. The nadir in heart rate was seen at the end of" the occlusion $(82.6 \%$ of control, a decrease from 173 to 143 bpm).

The changes in umbllical blood flow and arterlal blood pressure did not reach any level of slgniflicance (fig. 3.22).

The composite analysis of subgroup 2 ( 7 occlusions in 2 animals) shows the same degree and course in the heart rate change as with subgroup 1 . Arterlal blood pressure however decreased at the end of the occlusion (from $38.6 \mathrm{~mm} \mathrm{Hg}$ to $36.6 \mathrm{~mm} \mathrm{Hg}$ ), parallel with a decrease in umbllical venous blood flow of $23.1 \%$ to $338 \mathrm{ml} / \mathrm{min}$ at the end of the occlusion $(p<0.05)$.

Arterlal blood pressure increased in the recovery period to $9.6 \%$ (p<0.05) and $9.8 \% \quad(p<0.05)$ above control at respectively 30 and 60 seconds post occlusion.

Umbllical blood flow slowly returned to pre occiusion values at 2 minutes after the end of the occlusion $(\mathrm{f} 1 \mathrm{~g} .3 .23)$.

The changes in heart rate falled to reach a slgniflcant level. This was probably due to the small number of observations with a great standard deviation of the calculated mean.

Heart rhyth disturbances were seen in both subgroups especially during longer lasting occlustons. 


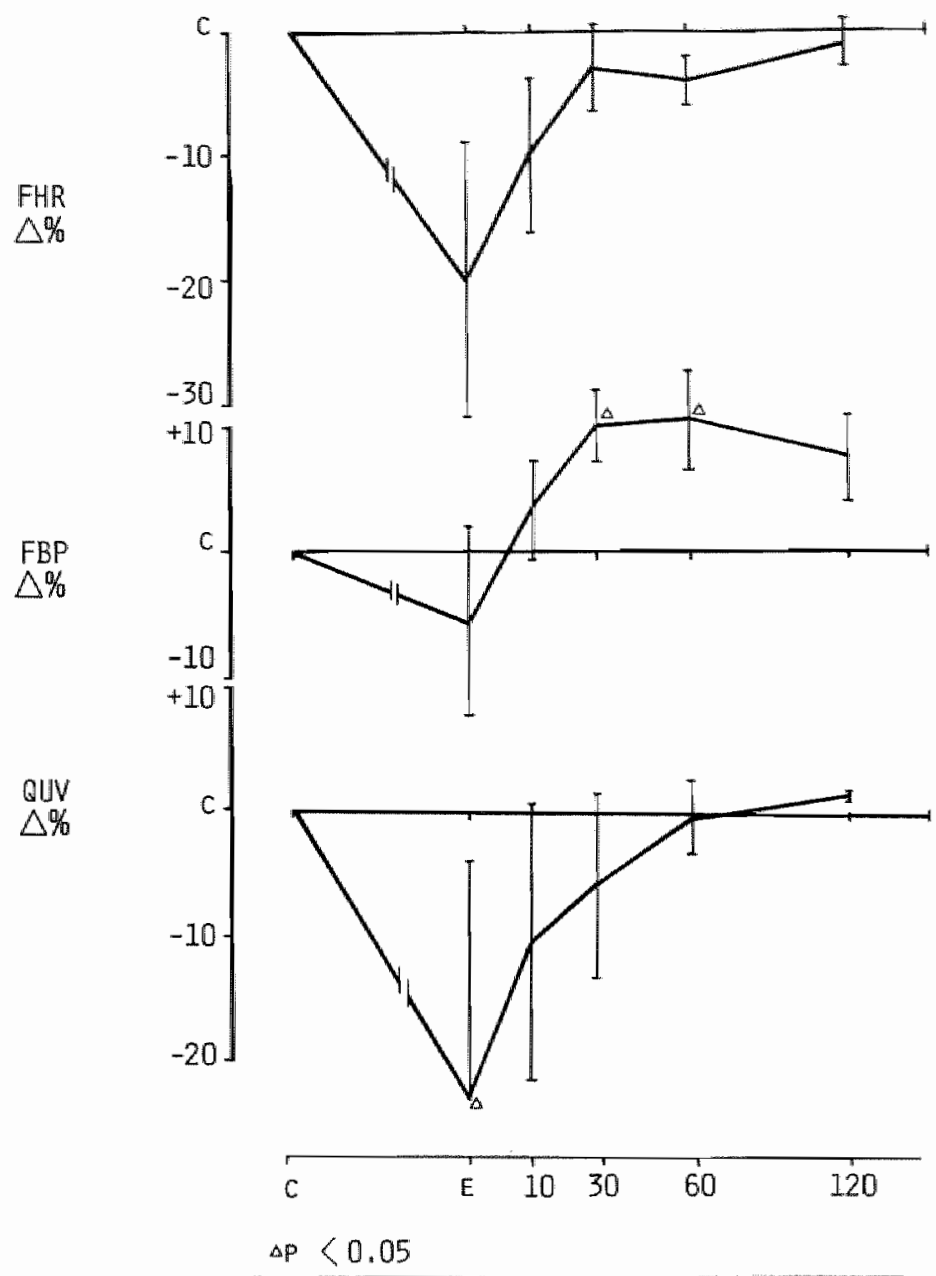

FIG 3.23 A COMPOSITE ANALYSIS OF THE CHANGES IN FETAL HEART RATE, ARTERIAL BLOOD PRESSURE AND UMBILICAL VENOUS BLOOD FLOW DURING AND AFTER THE OCCLUSION OF THE COMMON INTERNAL ILIAC ARTERY IN SUBGROUP II WITH BETA-ADRENERGIC BLOCKADE THE VERTICAL BARS BETWEEN C AND E REPRESENT THE VARIATION IN OCCLUSION TIME. 
3.6 Instantaneous umbilical venous blood flow patterns during occluslons of the matemal common Intemal lliac artery

During the fetal bradycardia assoclated with the matemal cormon intemal 111ac artery occlusion, biphasic pulsations in ilne with fetal heart rate occurred in the phasic umblilical venous blood flow pattern. These pulsations occurred both in the group with a hypertensive response as well as in the group with a hypotensive response during the occlusion (f'ig. 3.24). These pulsations were in line with fetal heart

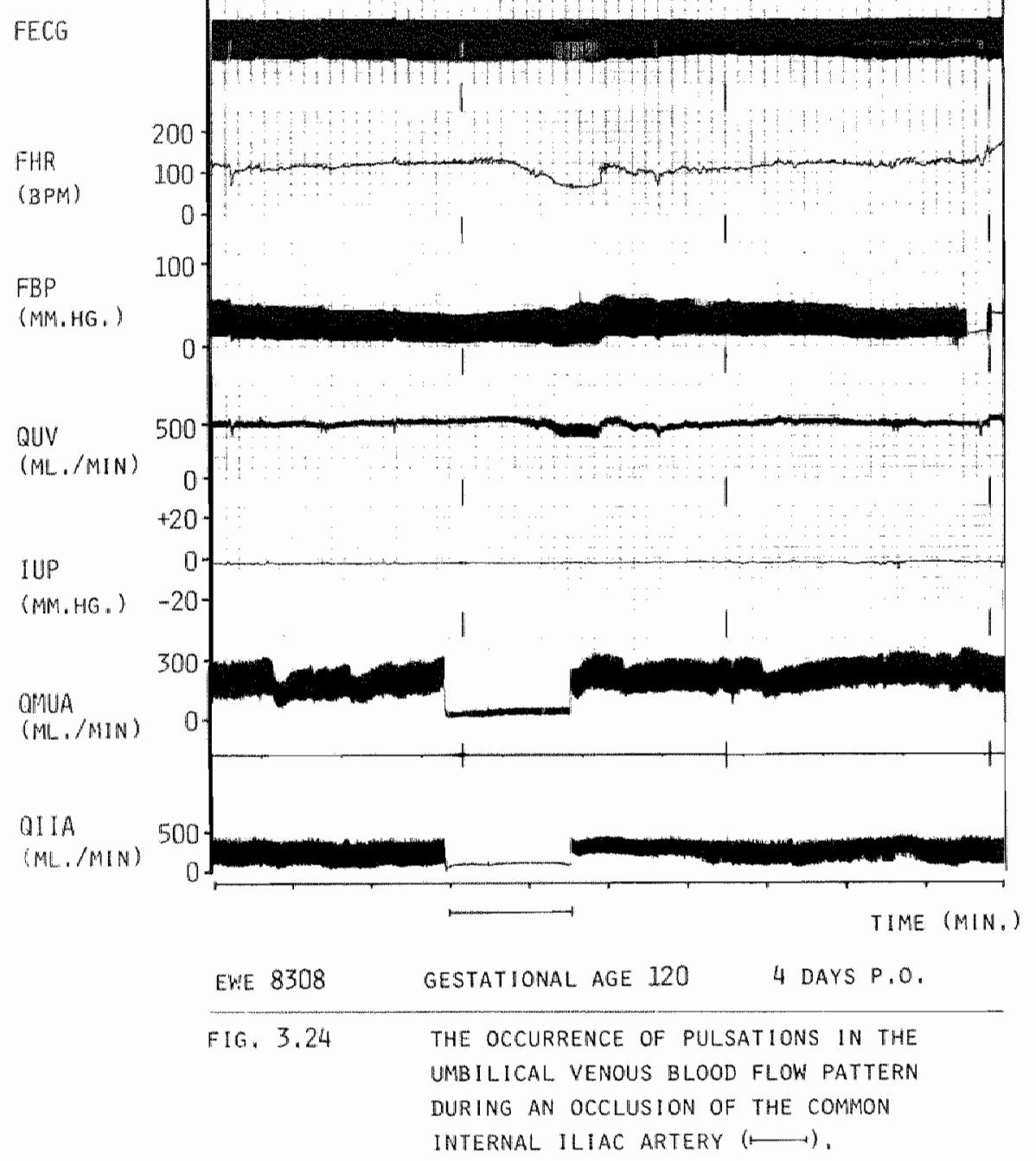


rate and consisted of two forward surges of venous flow, one maller simultaneous with the ventricular systole and a component greater in amplitude during ventricular diastole. After the dlastolio flow surge a decrease in flow occurred followed by an increase during the following ventricular systole ( $f 1 g .3 .25$ ).

These biphasic pulsations gradually decreased and eventually disappeared during the recovery phase in the fetal heart rate deceleration and thereafter.

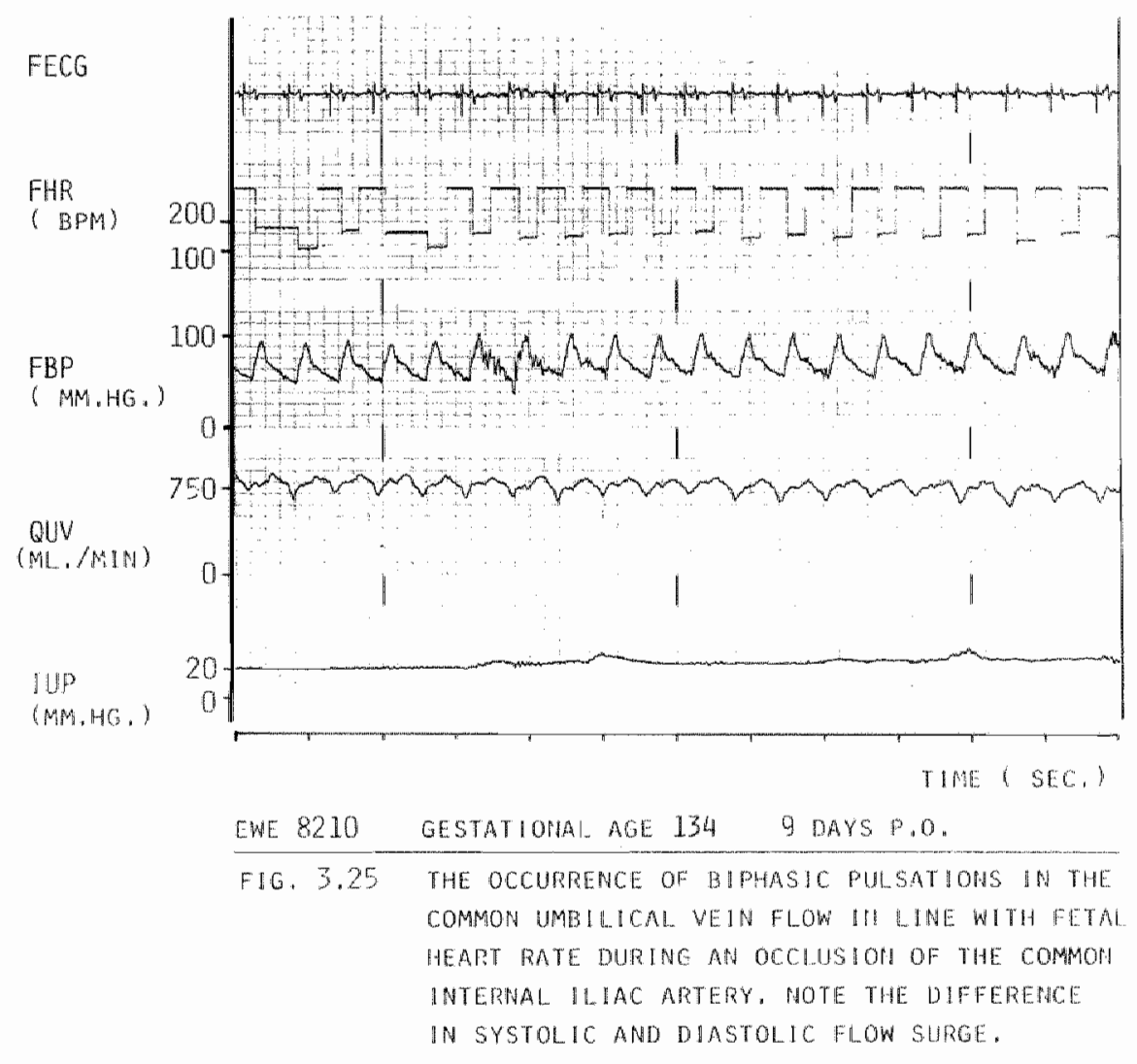




\subsection{D1scussion}

\subsubsection{Intact autonomlc nervous system}

Occlusion of the common internal 11 iac artery caused in sixty nine of the seventy five occlusions with an intact fetal autonomic nervous system a late deceleration in the fetal heart rate. These Intermutions of the uterine blood flow led to a decrease in the fetal oxygen status from normoxemia to a very mild hypoxemia at the end of each series of occlusions, together with the developnent of a mild hypercapnia and a decrease in fetal arterlal pH. The degree of hypoxemia which was reached during each individual occlusion is not known in these experiments, but may have varted substantialiy.

The fetal cardiovascular reaction pattern upon the decline in uterine blood flow could be divided in a group with an increase in arterial blood pressure and umblifical venous blood flow and a group with a decrease of these parameters during a late deceleration. If the reduction in uterine blood flow was assoclated with an increase in fetal arterial blood pressure, then also a signiflcant increase in umblilical blood flow was present. This indicates that the fetus who is capable of increasing its blood pressure during a late deceleration is also capable of increasing its umbilical blood flow thereby probably safeguarding its oxygen needs.

Increases in arterial. blood pressure during late decelerations in normoxemic fetal lambs under chronic experimental conditions have also been reported by others (Evers 1978, Martin et al 1979, de Haan et al 1979).

Parer et al (1980) found in a study with short reductions in maternal aortic blood flow of 20 seconds duration in nomoxemic fetal lambs ( $\mathrm{pO}_{2}$ $=20 \mathrm{~mm} \mathrm{Hg}$ ) no slgntficant changes in fetal arterial blood pressure. No slgniflicant change in unblilical arterlal blood flow was found as measured with an electronagnetlc flow transducer around the cormon umbilical artery in that study. This might be explained by the absence of a blood pressure response with the late decelerations.

In the group which showed a decrease in arterlal blood pressure (=group two, paragraph 3.5 .2$)$ the deceleration of the heart rate was greater 
than in the group which showed an increase in arterial biood pressure during the late decelerations (=group one, paragraph 3.5.2). In contrast to the increase in umbilical blood flow in group $I$, a highly significant reduction in umbilical blood flow was noted together with a decrease in artertal blood pressure in this group II.

A decrease in arterial blood pressure during late decelerations can be seen in hypoxemic and/or acidemic fetuses, followed by a secondary late increase in blood pressure during the recovery period (de Haan et al 1979, Martin et al 1979, Harris et al 1982, Itskovitz et al 1982a).

The Induced hypoxemia in such a condition may lead to a decrease in myocardial oxygen supply with a negative effect on the sinoatrial node (Senges et al 1979) which condition is in part responsible for the bradycardia of the late deceleration (Itskovitz et al 1982a, Harris et al 1982) and with a negative influence on the contraction force of the myocardium.

A diminished cardiac performance during the bradycardia may then be responsible for the decrease in artertal blood pressure and the subsequent fall in umbllical blood flow, as 1 t has been show that umbilical blood flow is positively correlated with arterial perfusion pressure (Berman et al 1976).

Although the fetuses from both the group (I) with an Increase in umbillcal blood flow as well as the group (II) with a decrease in flow had acid-base balances in the nornal range, while in fact that part of group II whose blood gases could be analysed even had higher $\mathrm{pO}_{2}$ and $\mathrm{pH}$ values, the degree of fetal hypoxemia during the occlusion is not known. It is 11kely in view of the present knowledge that fetal hypoxemia reached during the occlusion was more severe in the group with the umbilical flow decrease.

The overall condition of the fetuses from group I mlght furthermore have been better. Indirect evidence for this assumption is the ract that the delay between the start of the occlusion and the beginning of the fetal heart rate decline was longer in group I than in group II, which can also be inferred from the longer mean occluston time in group I.

Another difference is the interval between surgery and the moment of the experiment, which was much longer $(10 \pm 2.7$ days) for group I than 
group II $(6.7 \pm 2.2$ days). A better "physlological" condition of the fetus might be expected after a longer recovery from surgery. Furthermore the transition of a reactive hypertension during the first acclusions towards a decrease in blood pressure during the last occlusions in flwe experimental sessions also indicates a relation between the blood pressure response and the fetal condition during an occlusion of the common internal lilac artery.

An alternative explanation of the difference in blood pressure and flow responses between the 2 groups might be that a lesser degree of hypoxemia in group II (in keeping wtth the higher starting and ending pH and $\mathrm{pO}_{2}$ values) might have caused less stimulation of the chemoreceptors and falled to activate other mechanisms such as vasopressin release (Iwamoto et al 1979), resulting in cardlodeceleration with minimal vasoconstriction and blood flow redistribution. Besides the hilgher $\mathrm{pH}$ and $\mathrm{pO}_{2}$ values, the more rapld return of arterial pressure and umblical blood flow to control levels in group II would seen to support this explanation. Against this concept, however, are the shorter occlusion-deceleration delay time in group II (Itskovitz et aI 1982a), and also the fact that when transltions in response pattern occurred during an experiment, they were always from the hypertensive to the hypotensive pattern (see also 3.7 .2 and 3.7 .3 ).

As the fetuses from both groups were studied in the same perlod of gestation, no specific differences in the development of reflex mechanisms are to be expected between the two groups, especlally since the autonomic control of the fetal circulation is fully operational at the time of gestation at which the fetuses were studied (Vapaavourl et al 1.973, Nuwayhid et al 1975a).

Decreases in arterial umbilical blood flow and arter"lal blood pressure were reported by Harrls et al (1982) during late decelerations accomplished by short reductions (20 seconds duration) of maternal. aortic blood flow in hypoxemlic fetuses.

No signiflcant changes in umblilical vascular resistance durtng late decelerations produced by short lasting maternal aortic occlusion were found by Parer et al (1980) in nomoxemlc fetal lambs. General maternal and fetal hypoxemia Induced by breathing of a low oxygen gas mixture by 
the ewe, on the other hand caused a snall increase in unbilical vascular resistance in the study by Cohn et al (1982), while ub111cal. blood flow was matntalned by redistribution of cardiac output and Increased arterlal blood presisure.

The changes in the umbllical venous blood flow durdng the heart rate decelerations parallelled the changes in the arterlal driving pressure. Whether umb111cal vascular resistance changed during the common internal 11 lac artery occlusions in this study is not known, as umbllical venous pressure was not measured.

It is however obwlous that possible changes in umbll1cal vascular resistance assoclated with the Internal 1llac artery occluslons had no serlous adverse effect on umblical venous blood flow, if fetal. arterlal blood pressure increased towards the end of the occlusion (group 1). Although the decrease in umbilloal venous blood flow at the end of the occlusion period in group 2 can be explained by the concomitant fall in arterlal blood pressure, an increased umblilcal vascular resistance might possibly have added to this fall $1 \mathrm{n}$ blood Low. It is known, that unbllical vascular reslstance increases durling a more severe degree of hypoxemia (Cohn et al 1982), a supposed causative factor in the hemodynamic changes occurning in group 2 of this study.

\subsubsection{Cholinergic blockade with atropine}

The composite analyses of both subgroups show that chollnergic blockade wth atropine abolished the late deceleration in both subgroups and Instead a delayed acceleration in heart rate occurred.

The fact that the late deceleration could completely be blocked by atroplne in all Individual occlusions belonging to subgroup 1 shows that the vagal mediated cardlodecelerator reflexmechanlan was still present in this group. The mean data of all occlustons from subgroup? also show the absence of a fetal heart decrease. In 4 indlvidual occlustions of the 12 acclusions from this group however the occurrence of a bradycardia was not completely prevented by atroplne although the degree of heart rate slowing was reduced. This indicates that hypoxlo myocardial depression was a serlous causative factor in the heart rate 
deceleration assoclated with these occlusions, otherwise the heart rate depression would have been completely blocked after cholinergic blockade (Martin et al 1979, de Haan et al 1979, Harris et al 1982).

Arterlal blood pressure increased in both subgroups. This was expected In the experiments of subgroup 1. However no decrease but also a small increase in blood pressure was found in the experiments belonging to subgroup 2 .

This was probably the result of the increased heart rate in combination with the arterial blood pressure raising effect of atropine in higher doses (Goodman and G1lman 1975).

The changes in umblilical venous blood flow are caused by the concomitant increases in heart rate and arterlal blood pressure in both subgroups.

\subsubsection{Alpha-adrenergic blockade w1th phentolamine}

Alpha-adrenergic blockade with phentolamine prevented the peripheral chemoreceptor mediated reflex vasoconstriction.

Blood pressure thus fell in both subgroups but this decrease was more severe in subgroup 2. Any decrease in heart rate was minimal in subgroup 1 and was followed by an acceleration after the occlusion, but a severe and prolonged deceleration with a slow recovery of the heart rate was seen in subgroup 2 .

After the primary vagally mediated heart rate decrease due to chemoreceptor activity, a second causative step is the hypertension assoclated baroreflex induced cardiac slowing. The absence of a hypertensive response after alpha-adrenergic blockade explains the absence of heart rate decelerations in subgroup 1 . The deep heart rate deceleration in subgroup 2 suggests then that in this group a chemoreceptor mediated cardiac slowing response was present and probably an additional direct depression of myocardial chronotroplsm, whlch is in accordance with the assumption that fetal hypoxemia during the occlusion was more severe in subgroup 2. The difference in heart rate between the two groups during and after the occlusion explains the more depressed umbilical blood flow in subgroup 2 with a nearly equal fall in blood pressure in both groups. 
An Increase in umbilical vascular resistance can not be ruled out, but if this had happened, then it would be assoclated with the developing fetal hypoxemia as alpha-adrenergic blockade per se does not influence umbilical vascular resistance (see paragraph 5.4.1.2).

\subsubsection{Beta-adrenengic blockade with propranolol}

Beta-adrenergic blockade with propranolol did not essentially alter the hemodynamic responses in the two subgroups. Umbilical blood flow and arterial blood pressure increased during the heart rate deceleration under beta blockade. It has been suggested that the basal flow in the umbilical vascular bed is under a tonic beta- adrenergic influence (Chez et al 1978, Cohn et al 1982) and decreases after beta-adrenergic blockade with propranolol (see also paragraph 5.4.1.3). Beta-adrenergic blockade however did not prevent umbilical venous blood flow to increase parallel with arterial blood pressure during the heart rate deceleration in subgroup 1. The fall in umblilical blood flow in subgroup 2 was relatively great in vlew of the concomitant changes in heart rate and blood pressure.

A much greater increase in umbilical vascular resistance after beta-adrenergic blockade with propranolol was found by cohn et al. (1982) and Parer et al (1983) during fetal bypoxemia than with beta-adrenergic blockade or retal hypoxemia alone. Their findings suggest that beta-adrenergic activity is increased during hypoxemia, probably in order to maintain fetal heart rate and umbilical blood flow. The relatively great decrease in unbilical blood flow in subgroup 2 can then be explained on the basis of a considerably increased umbilical vascular resistance, provided that the assumption of a more severe fetal hypoxemia in subgroup? is correct.

3.7.5 Changes in the instantaneous umb1lical venous blood flow during occlusions of the common internal lilac artery

Umblilical venous blood flow shows no or only minimal pulsations unless fetal respiratory or other activity is present. 
S1tuat1ons thich Increase the amplitudes of the always pulsatile flow pattern in the venae cavae (Reuss et al 1983), may provoke pulsations In the comon umbl11cal vein by backward propagation through vena cava Inferlor and ductus venosus Arant11 to the common umbilical veln. The nature of these pulsations, the clrcumstances under which they occur and their possible consequence for fetal hemodynamics will be discussed in chapter 5 .

In this paragraph 1 th suffices therefore to say that the greater flow surge during ventrlcular diastole can be explained by the slow heart rate, allowing a longer atrlal. flling phase during diastole.

The results of this study show that fetal umbilical venous blood flow may Increase or decrease during late decelerations of the fetal heart rate caused by uterine blood flow obstruction.

The directlon of the blood flow change is mainly determined by the concomitant change in perfusion pressure, and to a lesser extent by the magnitude of the heart rate change. The influence of possible changes in umblilcal vascular resistance is not known from this study. The occurrence of a blood pressure decrease during a late deceleration in spite of the very fast appearing chemoreceptor mediated peripheral reflex vasoconstriction implies a decrease in cardiac output, probably resulting from hypoxlc myocardial depression. Redistribution of cardiac output which is an important fetal mechanlim to provide high-priority tissues as heart and brain with enough blood at the expense of low-prlority organs as e.g. Vlscera and musculoskeletal system, and which mechanim is assoclated with hypertension, is then endangered.

Observations in 4 antmals who got into spontaneous labor and whose fetuses showed late decelerations in thelr heart rate learnt that umbll1cal blood f'low could be malntalned early in the course of labor, when fetal hypertension was present during the heart rate decrease. When fetal condition was however deteriorating in a later stage of labor, arterlal hypotension ensued during the late decelieration instead of hypertension and umblilcal blood flow decreased. 
Flgure 3.26 shows part of such a recording with decrease of umbllical blood flow during a late deceleration. After correction for the superimposed intrauterine pressure it is clear that fetal arterial blood pressure decreases during the deceleration. Flgure 3.27 shows the mean values \pm SD calculated over Intervals of 10 seconds of part of the recording shown in 1 ig 3.26 .

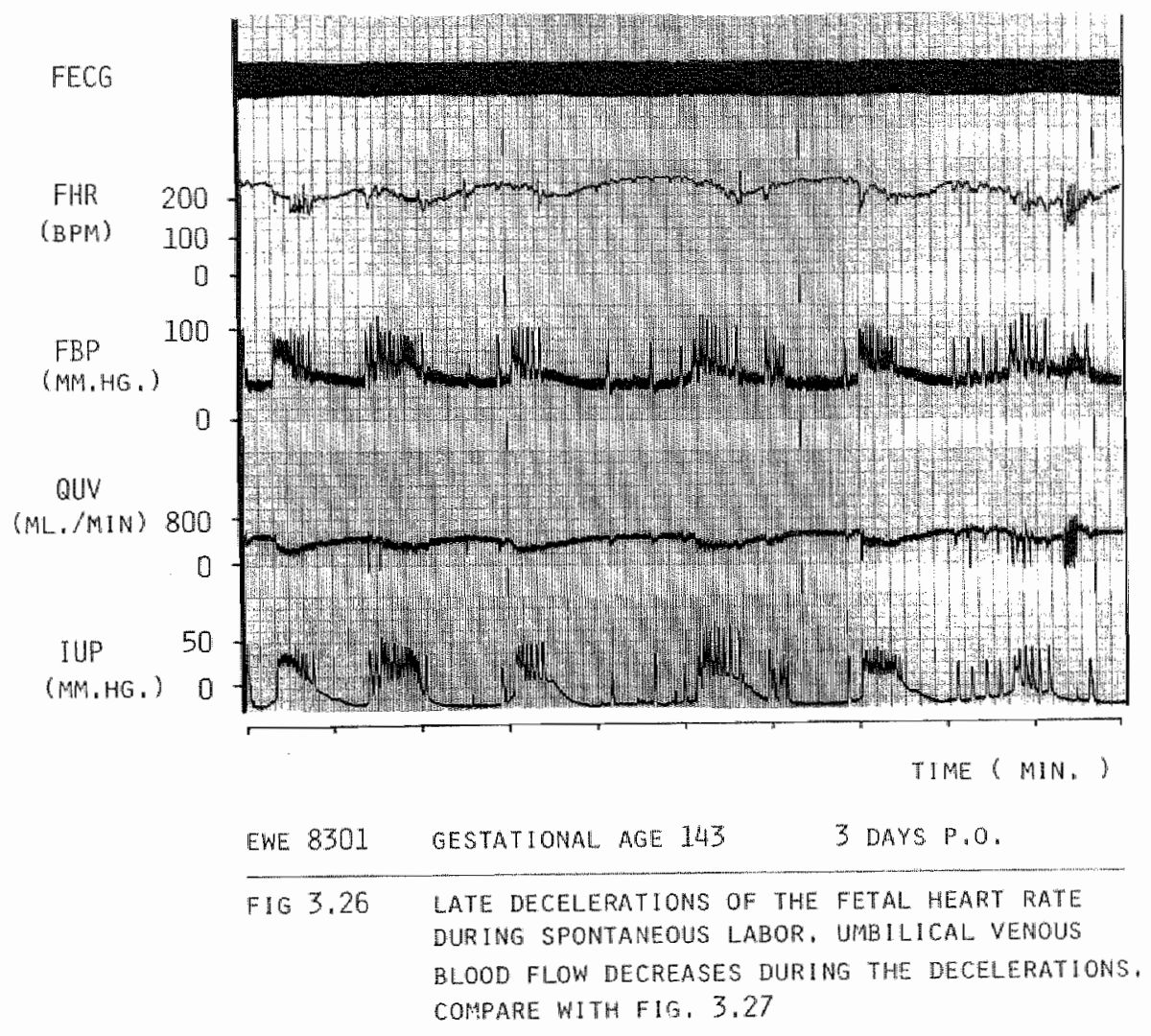


Conclustons from anmal studies are not atumatically applicable to the human, although observations from fetal lamb studies have contributed conslderably to the understanding of cardlovascular reaction pattems In the humbn fetus.

The occurrence of a late deceleration in a human fetus is always an andnous slgn, but between a waming slgnal and danger of life lles a scale of posilbilities. The presence of heart rate varlablitty, accelerations upon fetal movements etcetera all qualify the serlousness of the late deceleration to a certain degree. Quantitative analysis of une components of the late deceleration as has been done by Meyers et a1 (1973) In acute monkey preparations, might in combination with fetal. unbliticil blood veloctty measurements by means of pulsed Doppler systems, open a new approach to the study and the Judgment of the late deceleration heart rate pattem in the human.

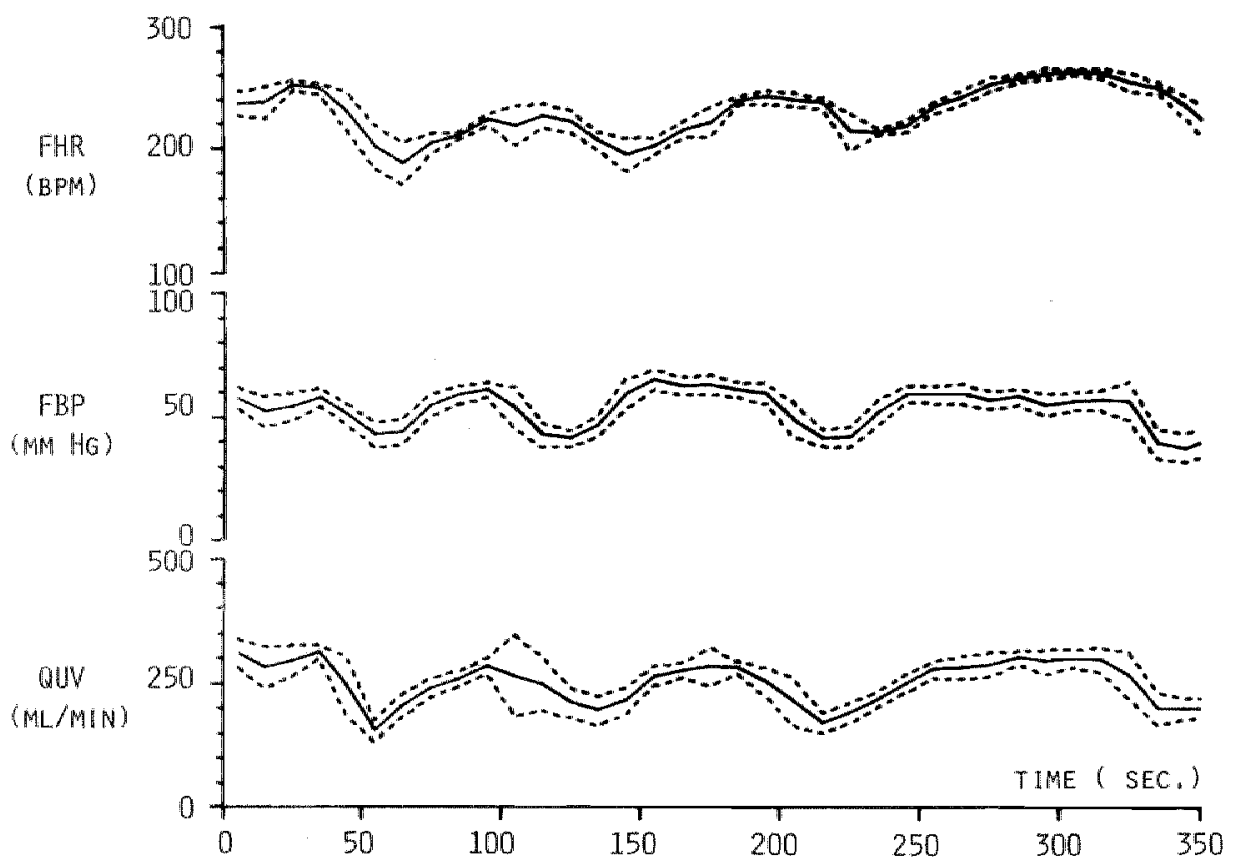

F16. 3.27 FETAL HEART RATE, ARTERIAL. BLOOD PRESSURE AND UMBILICAL VENOUS BLOOD FLOW DURING THE LATE DECELERATIONS DEPICTED IN FIG; 3.26 . FETAL ARTERIAL BLOOD PRESSURE IS CORRECTED FOR INTRA UTERINE PRESSURE CHANGES. NOTE THE DECREASE IN BLOOD PRESSURE AND UMBILICAL VENOUS BLOOD FLOW DURING A LATE DECELERATION. DATA ARE EXPRESSED AS MEAN \pm SD IN INTERVALS OF 10 SECONDS. 


\section{CHAPTER IV}

\section{UMBILICAL CORD OCCLUSIONS AND UMBILICAL VENOUS AND MATEERAL PELVIC BLOOD FLOW}

\subsection{Introduction}

Transient occlusion of the umbilical cord, recognlzable by variable decelerations in the fetal heart rate pattem in human cetuses, of ten occurs during labor. Entanglement of the cord is one of the major causes of cord occlusion during a contraction, but cord compression can occur in several ways in labor. Cord compression has striking effects on fetal hemodynamics, depending in severity upon the degree and the duration of the occlusion.

The umbilical vein with its relatively low pressure and its nonpulsatile flow is easily compressed by the uterine contraction force. Compression of the umbilical arteries takes more force because of their higher and pulsatile pressure, but complete obstruction of the umblilical cond can probably occur with an uterine contraction. The typical varlable deceleration fetal heart rate pattern, that accompanies cord occlusions, is extensively described by Hon (1968). Varlable deceleration has the following characteristics. It varies markedly in shape from uterine contraction to uterine contraction, and does not reflect the shape of the assoclated uterine contraction curve. The onset of the deceleration bears a varlable time-relationshlp to the besinning of the associated uterine contraction. The duration of the deceleration varies from a few seconds to minutes and the fall in heart rate is usually below 100 beats per minute and is frequently as low as 50-60 beats per minute or less.

The pattern of the variable deceleration probably varies with the degree of venous or venous and arterlal unbilical flow obstruction, the 
duration of the occlusion and fetal oxygen state before the occlusion.

\subsection{Mechanisus of the varlable decelerations}

The varlous explanations of the mechanlsms underlylng the variable deceleration have been obtalned largely from andmal studies. Bauer (1937) studied the alowing of heart rate produced by clamping the umblilcal cord in the fetal sheep and goat and noted a considerable delay in the slowing of fetal heart rate after sectloning of the cervical vagal nerwes. Barcroft (1946) ascribed the inftial fall in fetal heart rate to vagal stimulation and the residual bradycardia after vagotony to direct hypoxic depression of the myocardium (see also paragraph 3.2). Partial occlusion of the umbilical cord or the Losolated intraabdominal vein in near-tem pregnant baboons and Rhesus monkeys resulted in the well-oxygenated fetus in transient acceleration of heart rate and a decrease in pulse pressure in a study by James et al (1976). This response was abolished after alpha-adrenergic blockade with dibenzyline or beta-adrenergic blockade with propranolol. In the hypoxic fetus however partial occlusion resulted in elther bradycardia and hypotenston or hypotension with no alteration in heart rate. James concluded that transient acceleration of the fetal heart rate can be explained on the basis of a sympathetic response to diminished venous return.

The same type of study was done by de Haan et al $(1976,1979)$ and Evers (1978) in the chronically instmunted fetal sheep. With the use of a spectal occluding device separate occlustons of the umbllical veins and/or arterles were performed. They found an intitial decrease of systollc and diastollc arterial pressure after occlusion of the umbllical velns, followed by an increase during the rest of the occluslon. A snall increase in fetal heart rate often preceded the following decrease. "The inttial decrease in arterlal pressure following venous occlusion must be caused by an initial decreased venous return to the right heart due to a certain amount of blood trapped in the placental. clrculation, until arterial pressure is maintained in the rest of the circulation (de Haan et al 1976, 1979, Evers 1978). Total occlusion of both unbliical arteries or the total unbilical cord 
resulted in an imediate rise of systollc and diastollc pressure, followed by a second rise after a variable time to a cerain steady-state level. The fetal heart rate decreased Imediately after the occlusion to a certain level and was followed by a second decrease accompanying the second rise in fetal blood pressure. complete occlusion of the umbilical arteries or total umbillcal cord will lead to a sudden marked increase in perlpheral vascular resistance since about $40 \%$ to $50 \%$ of fetal total cardiac autput is unbll1cal blood flow (Cohn et al 1974, Peeters 1978, Rudolph and Heymann 1970). This Leads to an immediate rise in arterial blood pressure, followed within 1 to 2 seconds by a decrease in fetal heart rate as a result of carotid baroreceptor stimulation which can be blocked by atropine in the fetal lamb (De Haan et al 1976, Evers 1978).

Muller-Heubach and Battelli (1982) performed tatal umblilcal cord occlusions for 15 or 39 seconds in Rhesus monkeys under anesthesia. They found an inltial short-lasting rise in blood pressure with cord acclusion followed by a decrease in blood presisure which crossed in most experiments the baseline blood pressure present before cord occlusion. They concluded that the initial baroreceptor stimulation is of Iinted duration and the continued decline in fetal heart rate whlle fetal blood pressure decreases Irom a peak has to be attributed to chemoreseptor stimulation in view of the continuing linear rall of transcutaneous $\mathrm{pO}_{2}$, whlch measurement has a high correlation with the $\mathrm{pO}_{2}$ measured in arterial blood.

De Haan et al (1976, 1979) ascribed the second lncrease in arterial pressure during clampling of the cord to vasoconstriction based on a decrease in partlal oxygen presisure, $1 . e$ also chemoreceptor mediated. It is likely that blood pressure would heve been decreased with longer lasting occlusions causlng a more severe fetal hypoxemla with direct myocardial depression in their experiments.

There are however differences in experimental conditions between the studies from de Haan et al (1976, 1979) and Mueller-Heubach and Batteli1 (1982), as the antmal under study, the varlation in occluston time and chronic versus acute experiment.

The role of chemoreceptor activity, which exists during the latter thind of gestation in fetal lambs (Dawes et al 1969), in fetal heart 
rate changes caused by mbl11cal cord compresslon has been studied in dellvered fetal lambs which were conmected to a membrane oxygenator replacing the ventilatory function of the placenta by stassi et al (1979). They showed that variation of arterial oxygen tension from 220 to $20 \mathrm{~mm} \mathrm{Hg}$, an after all unphyslologlaal range as nomal fetal arterial oxysen tension $18 \mathrm{in}$ the range of 20 to $30 \mathrm{~mm} \mathrm{Hg}$, was assoclated with progresslve Increase in blood pressure and heart rate, Indlcating presence of chemoreceptor activity throughout this range of arterlal oxygen tension. Cardlac decelerations and blood pressure rlses were less in hyperoxemic fetuses which were in a state of reflex perlpheral vasodllation compared to the responses in normoxemic fetuses which were 1 in a state of reflex perlpheral vasoconstriction. They postulate that heart rate deceleration as a result of unbllical cord occlusion is in part due to immediate chemoreflex-medlated bradycardia whloh acts in a synergistlc manner with baroreflex responses. The memoreceptor sensitivity may be lncreased at lowered levels of arterial oxygen tension, which can explain the greater deceleration ellolted during fetal nomoxenta in contrast to fetal hyperoxemia.

Kunzel et al (1980) found in acute fetal lamb studies that the first response to total cord occlusion took place w1thin 0.25 seconds, a very unlikely value, as the sum of the affecent, central and efferent conduction tumes of the vagally mediated baroceflex is 600 msec (Borst 1979). Thelr following conclusion $1 \mathrm{~s}$ however not invalid by this difference. When taking the fetal clrculation time from the umbilical vein to the carotid artery which $1 \mathrm{~s} 1.9 \pm 0.2$ seconds (Power and Longo 1975) Into account, then an inttal chemoreceptor response due to hypoxle is excluded, so that the Initlal cardiovascular response has to be baroreceptor medlated.

In sumary, the reflex mechanlsms regulating fetal cardiovascular adaption to cord compression are prlmarliy baroreflex mediated, followed by ar in comblnation with a chemoreceptor response induced by hypoxemia, and eventually the effects of drect hypoxic myocardial depression on heart rate and arterlal pressure are added. So the sequence of the reflex mechanlams underlytng the varlable deceleration ls not the same in case of the late deceleration, in whlch the first part of the deceleration is chemoreceptor medlated, followed by a 
baroreceptor response (paragraph 3.3 ).

\subsection{Umbilical venous blood flow and cord compression}

Total umbilical cord occlusion leads to exclusion of the placental circulation with a total stop of fetal umblical circulation. The concomitantly occurming changes in heart rate and blood pressure have been described before. Mean umbilical blood flow is expected to becone zero after total cord occlusion.

The flow pattern in the cammon umbillcal veln shows normally no or minimal pulsations, in contrast to the flow patterns in the fetal superior and inferior venae cavae which have a phasic pulsatile character (Reuss et al 1983). The pulsatility in the venae cavae increases under several conditions like slower heart rates, hypoxemia and changes in ventricular afterload (Reuss et al 1983). These factors al.so evoke biphasic pulsations in the common umbllical vein, in line with fetal heart rate (Hasaart and de Haan 1983). The appearance of biphasic pulsations in the cormon umbilical velin and their relationship with heart rate and blood pressure was studied durtns total cord occlusion and the immediate post occlusion period.

\subsection{Pelvic arterial blood flow and cord compression}

It is evident that decreases in matemal uteripe flow or vascular pressure influence the fetal circulation if the fetal oxygenation becomes compromised by the flow reduction, as has been outlined in chapter 3. Power and Longo proposed in 1973 that a placental tissue pressure is generated by the uterine vascular system surrounding the fetal placental efreulation. This placental tissue pressure may be an important factor in the regulation of the umblifical flow. This sluice flow or waterfall mechanism, as 1 t was referred to by Thomburg et al (1976), would enable changes in maternal uterine flow or vascular pressure to Influence the fetal clrculation. The slulce flow model states that blood flow through a system of collapsible channels whlch are surrounded by a pressure exceeding venous outflow pressure is directly proportional to the difference between inflow pressure and 
sumoundiris pressure, and Inversely proportional to the reslstance of the rlgud vascular elements, but is unaffected by outflow pressure as long as outflow pressure is lower than surrounding pressure (Beman et ail 1976$)$.

The experiments in this respect by Power and Longo (1973) were performed in the fetal circulation of a single cotyledon of the sheep placenta, whlle Blssomette and Farrell (1973) perfused the entire unbilical clrculation of near-tem fetal lambs after removal of the fetus. This concept implies that a rise in uterine venous pressure would increase placental tissue pressure surrounding the unbllical vascular bed with a greater resistance to fetal placental flow as result. Umbllical flow would then fall. The effects in the fetal circulation of the matemal hypotensive supine symarome during human pregnancy could be explained in this way.

A fall in utertne arterial pressure or a fow reduction on the other hand would decrease the surrounding placental tissue pressure and therefore decrease umblilcal placental vascular resistance with an increase in umbllical flow as result. However, Thomburg et al (1976) relnvestigated this problem in chronically instrumented near-term sheep. They report that changes in uterine venous pressure in the physlologloal range from 2 to $30 \mathrm{~mm} \mathrm{Hg}$ did not affect the umbilical vascular resistance. The same results were obtained by Berman et al (1976), also in a chronic sheep preparation. They found that changes in maternal arterlal and venous pressure within the physlological range did not alter umbllical blood flow.

According to these two series of experiments which were perfomed in a chronlc preparation in a certainly better physlologlcal condition thar the acute perfused placenta preparations, there 1 s no evidence that the placental waterfall phenomenon exists in the fetal sheep. In a continuation of thelr work from 1973 Power and Gilbert reported in 1977 however that changes in pressure on the maternal side of the placenta, caused by occlusion of the vera cava inferior or the distal aorta produced changes in fetal umblilcal compliance. These experiments were done in the acutely perfused placenta preparation with cut unbllical vessels and moreover umblilcal compliance was measured within a pressure range of 40 to $80 \mathrm{~mm} \mathrm{Hg}$, totally unphyslologlcal values for 
the umbllical veins.

Any valla conclusion for the intact in vivo situation cannot be drawn therefore from this latter study.

On the other hand the placental waterfall concept has also been used to propose that changes in pressure and flow in the fetal placental vasculature may conversely influence the maternal placental. circulation. Berman et al (1976) and Rudolph (1976) however found no measurable effect on uterine blood flow upon an elevation of umblilcal venous pressure or a reduction of umbillical arterial pressure.

Recently cottle et al (1982) reported a decrease in median uterine blood flow in response to longerlasting (4 minutes) cord compression in a chronle sheep model.

In the experiments by Beman et al and Fudolph only partial and very short lasting flow obstructions in elther the comon umbilical. veln, or the fetal distal aorta were perfomed posslbly not sufficlent enough to establish matemal flow changes, whlle cottle et al (1982) performed long lasting occlusions of the total umbllical cord. Moreover in the former studies blood flow in the common internal iliac artery was measured, the teminal branch of the aorta, that also supplies the nonpregnant uterine hom and other extrauterine structures with blood. Possible changes in maternal placental blood flow might not be reflected in the mean flow of this vessel. The measurements by cottle et al were performed in the median uterine artery, directily adjacent to the uterine wall and anly providing the utemus and its contents with blood. They suggested that fetal release of catecholamines or tricreased fluid pressure in the fetal placental tissue or a combination of these mechanisms might be involved in the uterine flow depression durlng cord compression. The maternal uterine bed 15 highly senstive for catecholamines and reacts with a vasoconstriction upon 1 ts adinintstration (Grelss 1963, Grelss and Plck 1964). Catecholamines are released from the fetal adrenal medulla in response to hypoxem1a (Comline et al 1965), and they may constrlct the maternal vascular bed after transfer over the placenta from the fetal to the maternal side. Evidence of placental transfer of catecholamines is however conflicting. Jones and Roblnson (1975) detected no labeled catecholamines of fetal origin in the matemal circulation in sheep 
whereas reduced uterine blood flow after intravenous administration Into sheep fetuses was reported by chez et al (1978). Rankin and Phernetton (1976) also observed a fall in uterine blood flow subsequent to the injection of norepinephrine to the fetal lamb.

An Increased tissue pressure in the fetal placenta during cord occlusion mlght altematively or add1tionally helghten resistance in the matemal placental circulation with a flow reduction as result.

In this chapter the results of total umbilical cord occlusion upon the bllood flow in the matemal Internal 1liac artery and median uterine artery w11 be presented as well as the instantaneous flow pattems in the comon umbllical veln during and immediate arter cord occlusion. 


\subsection{Materials and methods}

A total number of 92 umbilical cord occlustons with simultaneous matermal Plow measurements were performed in 8 animals. The matemal blood flow measurements were distributed as follows. The blood flow in the median uterine artery was measured during 69 cord occlusions in 7 animals. The blood flow in the internal 11 lac artery was also measured during 69 cord occlusions in 7 animals (see table 2.5). Simuitaneous measurement of the intermal iliac artery blood flow as weil as the blood flow in the median uterine artery was possible in 46 cord occlusions in 6 animals.

Table 4.1 shows the data on gestational age, number of days after surgery at the time of the occlusion experiment and the duration of the occlustion.

\begin{tabular}{l|cc}
\hline & MEAN \pm SD & RANGE \\
\hline GESTATIONAL AGE (DAYS) & $120 \pm 2.5$ & $114-133$ \\
\hline TIME AFTER SURGERY (DAYS) & $7.6 \pm 2.5$ & $3-26$ \\
\hline OCCLUSION TIME (SECONDS) & $40.1 \pm 3.3$ & $20-90$ \\
\hline
\end{tabular}

TABLE 4.1 GESTATIONAL Age, TIME AFTER SURGERY AMD OCCLUSION TIME OF THE 92 UMBILICAL CORD DCCLUSIONS IN 8 ANIMALS.

The instantaneous umbilical venous blood flow pattern in the fetuges with an intact autonomic nervous system was studied during the cord occiusions of the above mentioned group.

The instantaneous umbilical venous blood flow pattern during umblilical cord occlustons was also analysed after selective blockade of the cholinerg1c, alpha-adrenergic and beta-adrenergic part of the autonomic nervous system of the fetal lamb. 
The mean values of the blood flow in the intemal 11 iac artery or the median uterine artery calculated over an interval of 10 seconds were pooled and statistically analysed.

The control values $(=\mathrm{C})$ were obtalned from a perlod 10 seconds before the start of the occlusion. Control values were then compared with the mean values calculated from the last 10 seconds of the umbillcal cord occiusion $(=$ E), the Interval o to 10 seconds after the occlusion $(=10)$, the Interval 60 to 70 seconds after the occlusion $(=60)$ and finally with the mean value about two minutes after occlusion $(=120)$, calculated over the interval 110-120 seconds after the occlusion.

Data were expressed as percent change \pm SEM with control values as the $100 \%$ reference level. Statist1cal analysis was done by means of W1 coxon's matched-palrs signed-ranks test. All p-values were calculated for two talled tests.

\subsection{Results}

\subsubsection{Matemal intemal lliac artery blood low during umbilical cord occlusion}

The blood flow in the matemal 1ntemal 11 lac artery was slgniflcantly (p<0.001) reduced at the end of the ocolusion to $93.9 \%$ of the control value $(=330 \mathrm{ml} / \mathrm{min})$. Internal $11 \mathrm{lac}$ artery blood flow was also signiflcantly ( $<<0.001$ ) less tham the control value at the first 10 seconds after the end of the acclusion. The values at 60 and 120 seconds did not signiflaantly differ from the control value. Table 4.2 show the mean values \pm SEM for the internal 111 ac artery blood flow expressed In percent change from control.

\subsubsection{Matemal median uterine artery blood flow during umbilical. cord occlusion}

The blood flow in the median uterine artery was signiflcantly ( $p<0.001)$ reduced at the end of the occlusion and at the flrst 10 seconds after the end of the cord occlusion to respectively 91.7 and $94.9 \%$ of the control value $(=256 \mathrm{ml} / \mathrm{min})$. A still slgniflcant decrease $(p<0.05)$ in 


\begin{tabular}{|c|c|c|c|c|c|}
\hline & $\begin{array}{c}c \\
=69\end{array}$ & $\begin{array}{c}E \\
n=69\end{array}$ & $\begin{array}{c}10 \\
=6\end{array}$ & $\begin{array}{c}60 \\
=\quad 50\end{array}$ & $\begin{array}{c}120 \\
=69\end{array}$ \\
\hline MTERNAL WUIAC ARTERY & 100 & 93.911 .1 & $94.8^{2} 1,1$ & $97,5 \pm 1,2$ & 98.541 .5 \\
\hline
\end{tabular}

sp $<0.001$

TABLE 4,2

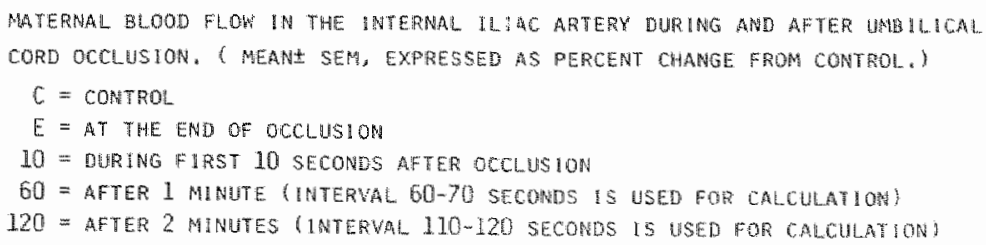

uterine blood flow was found at 60 seconds after the end of the occlusion (97.2\% of control value). Mean uterine blood flow at 120 seconds post occlusion did not differ significantly from the control. value. Figure 4.1 shows the mean values \pm SD calculated over intervals of 10 seconds of fetal umblilical blood flow and maternal medlan uterlne artery blood flow in a single umbilical cord occlusion experiment. Table 4.3 shows the mean values \pm SEM for the median uterine artery blood flow, expressed in percent change from control.

\begin{tabular}{|c|c|c|c|c|c|}
\hline & $N=69$ & $\begin{array}{c}E \\
N=69\end{array}$ & $\begin{array}{l}10 \\
=69\end{array}$ & $\begin{array}{c}60 \\
N=69\end{array}$ & $\begin{array}{c}120 \\
=69\end{array}$ \\
\hline MEDIAN UTERINE ARTERY & 100 & $91,7 \pm 1,1$ & 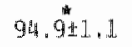 & $97.2 \pm 1.3$ & $97.2 \pm 1.5$ \\
\hline
\end{tabular}

$$
+0,001
$$




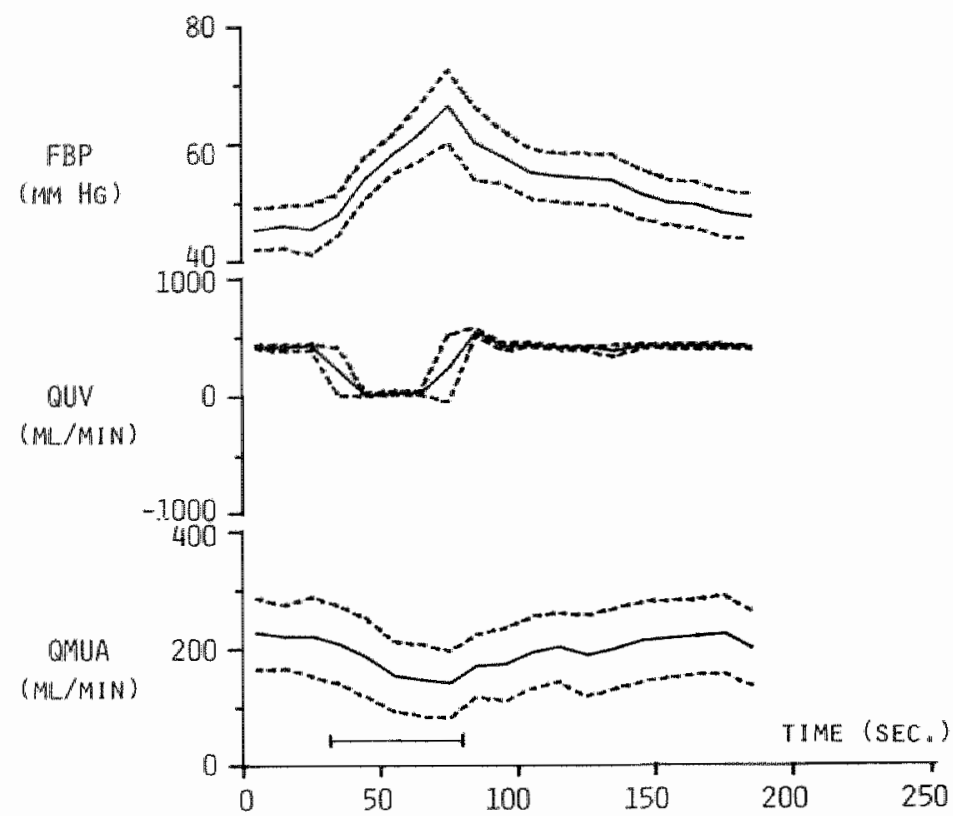

FIG, 4, I CHANGES IN MEDIAN UTERINE ARTERY BLOOD FLOW DURING AN UMBILICAL CORD OCCLUSION (… DATA ARE EXPRESSED AS MEAN \pm SD IM INTERVALS DF 10 SECONDS. THE GRADUAL CHANGES IN QUV AT THE BEGIN AND END OF THE OCCLUSIOM ARE DUE TO THE WAY OF GRAPHICAL EXPRESSION.

4.6.3 Simultaneous measurement of maternal internal 11 lac artery and median uterine artery blood flow during umbilical cord occlusion

The data of the blood flow changes in the intemal 1liac artery and median uterine artery during umbilical cord occlusion showed a greater reduction in median uterine artery blood flow than in the internal 1 liac artery flow.

Part of the data of these two groups were however obtalned from different experiments. Therefore the data on the matemal blood flow during cord occlusion were also analysed in the 46 occlusions in which Internal 1llac artery and median uterine artery blood flow were 
measured simutaneously. The blood flow in the maternal internal $111 \mathrm{ac}$ artery was slgniflcantly reduced at the end of the ocolusion and at first the 10 seconds after the end of the cord occluslon to respectively $94.3 \%(p<0.001)$ and $96.8 \%(p<0.01)$ of control value $(=317$ $\mathrm{mil} / \mathrm{min})$. A st117 significant $(p<0.05)$ decrease in intemal $111 \mathrm{ac}$ blood flow was found at 60 seconds post occlusion.

Median uterine artery blood flow was also slgnlflcantly reduced at the end of the occlusion and at the rirst 10 seconds after the end of the cord occlusion to respectively $93.6 \%(\mathrm{p}<0.001)$ and $96.2 \%$ (p<0.01) of control value $(=236 \mathrm{ml} / \mathrm{min})$.

At 60 seconds post occlusion median uterine artery blood flow was st111. significantly ( $p<0.02)$ reduced to $96.6 \%$ of control walue.

The absolute values of the flow decreases were about the same in both vessels. Flgure 4.2 shows the mean values $t$ SD calculated over intervals of 10 seconds of fetal umbllical blood flow and matemel. internal Lllac and median uterine artery blood fllow in such an Pexperiment.

Table 4.4 shows the mean values \pm SQM for both maternal blood flows expressed in percent change from control.

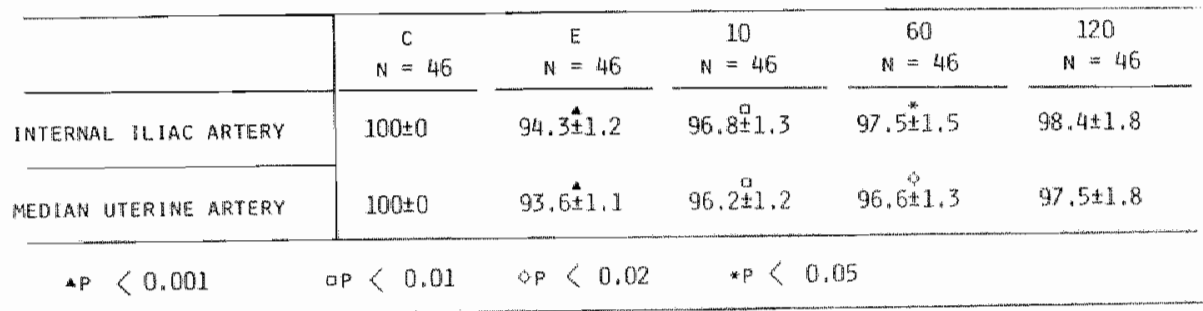

TABE 4.4 WATERMAL BLOOD FLOH AS MEASURED SIMULTAREOUSLY IAT THE INTERMAL ILIMC ARTERY HND THE MEDIAN UTERHNE RRTERY DURING AND AFTER UME HLICAL CORD OCCLUSION ( MEANASEM, EXPRESSED AS PERCENT CHAMCOE FOHO CONTROL). SEE ALSO LEGEND TABLE 4.2 


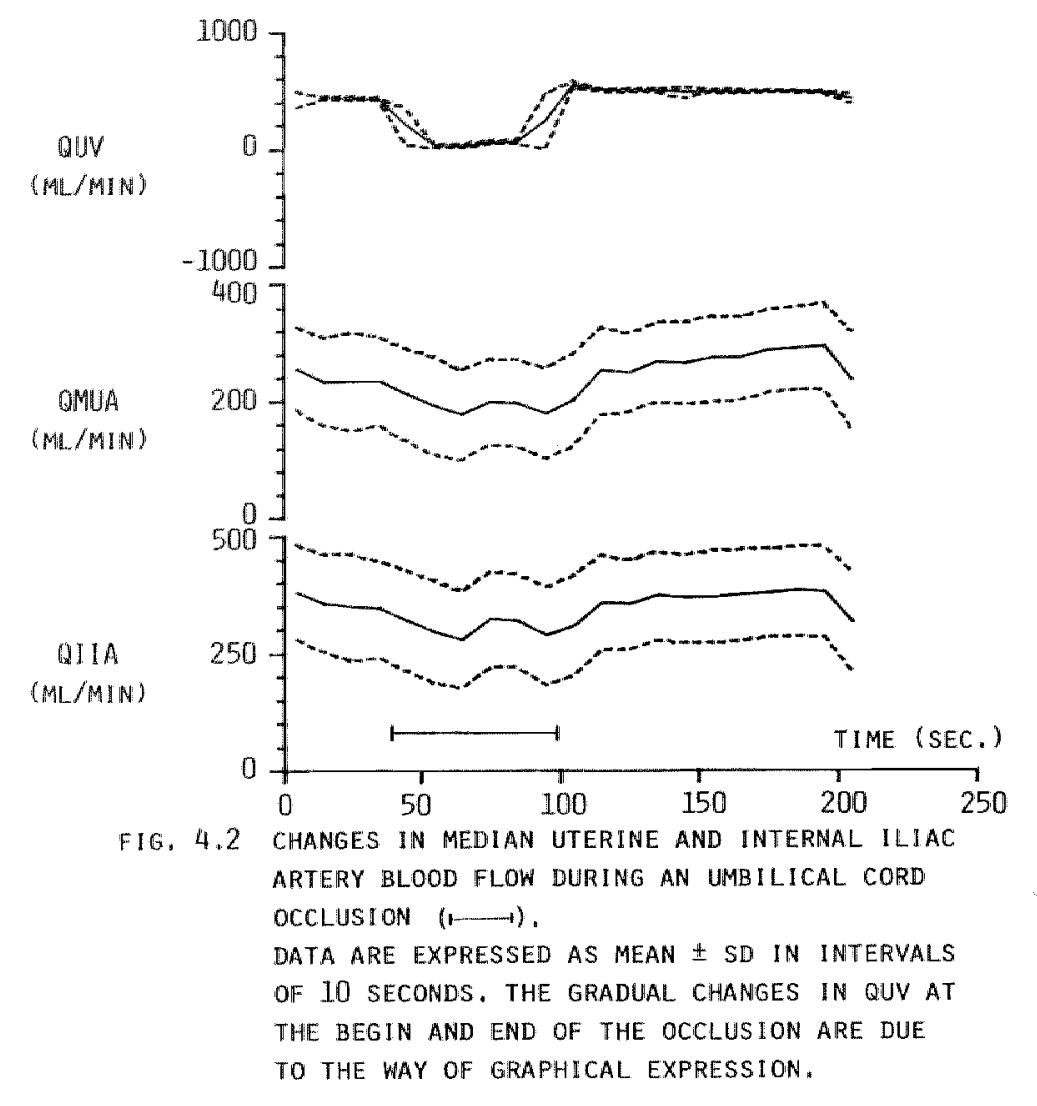

\subsection{Instantaneous umb111cal venous blood flow during occlusion of the umbilical cord}

\subsubsection{Intact autonomic nervous system}

Inflation of the balloon occluder around the total umbilical cord led to an increase in mean artertal blood pressure and a decrease in heart rate, phenomena which have been described extensively (de Haan et al 1976, Kunzel et al 1977, 1980, Evers 1978, De Haan et al 1979, Mueller-Heubach and Battell1 1982, Itskovitz et al 1983). 
Umbilical venous blood flow abruptly decreased during cord occlusion and with complete inflation of the balloon, a total blockade of venous bload flow was accomplished.

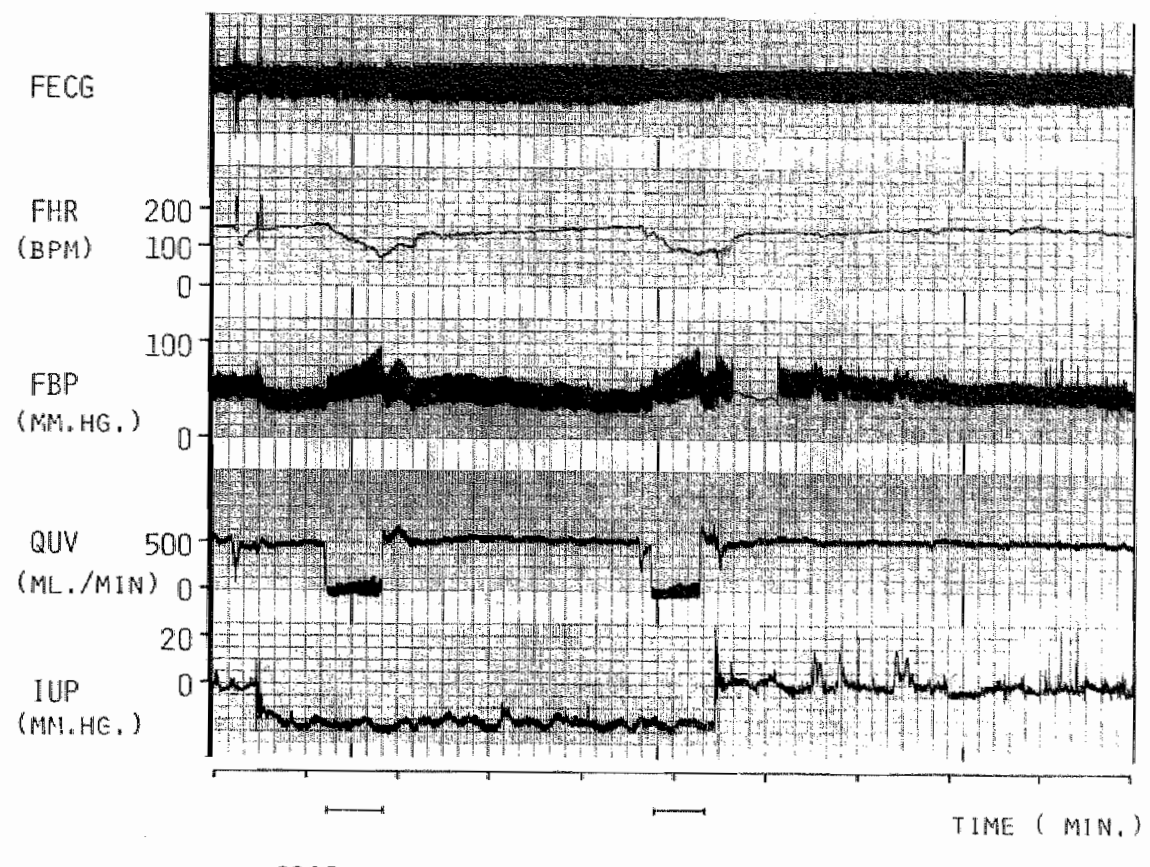

EHE 8216 RESTATIOMAL AGE 126 26 DMYS P.O.

FIG. 4.3 THE OCCURRENCE OF PULSATIONS IN THE PHASIC FI.OK PATTERN OF THE COMMON UPBILICAL VEIN. ( W UIBILICAL CORD OCCLUSION )

THE ABRUPT CHANGES IN IUP ARE CAUSED BY A POSTURAL CHANGE OF THE EME.

The Instantaneous 10w pattern in the comon umb1110a] veln which under steady-state conditions showed no pulsations, changed dur.tng cord occlusion to a pattem with biphasic pulsations in line with fetal. heart rate. This change occurred both in the stututions in whloh umblilcal venous blood flow was only partlally reduced by incomplete Inflation of the occluder as wel. as in those experlments in whlch a complete blockade of venous blood low was established (fig 4.3$)$. In 
the later situatlon no mean fomward flow was present of course, in contrast to the experiments with only partialiy reduced umblilical blood flow. The blphaste pulsatlons appeared after a certain delay after the beglnning of the cord occlusion and gradually increased in amplitude to reach thelr maximum amplitude immediately before the end of the acciuslon. Maximum pulsatility was seen with high blood pressure Increases and deep bradycardla. An overshoot of umbllical vemous blood 1.low was found after release of the cord occlusion. The pulsations were then abmupty dintnished in size or had even disappeared (11g.4.4). If the pulsatlons were st111 present in a lesser degree after the occlusion, then they were extingulshed within several seconds after the occlusion, unless fetal bradycardia and hypertension were st111 pronounced at that time.

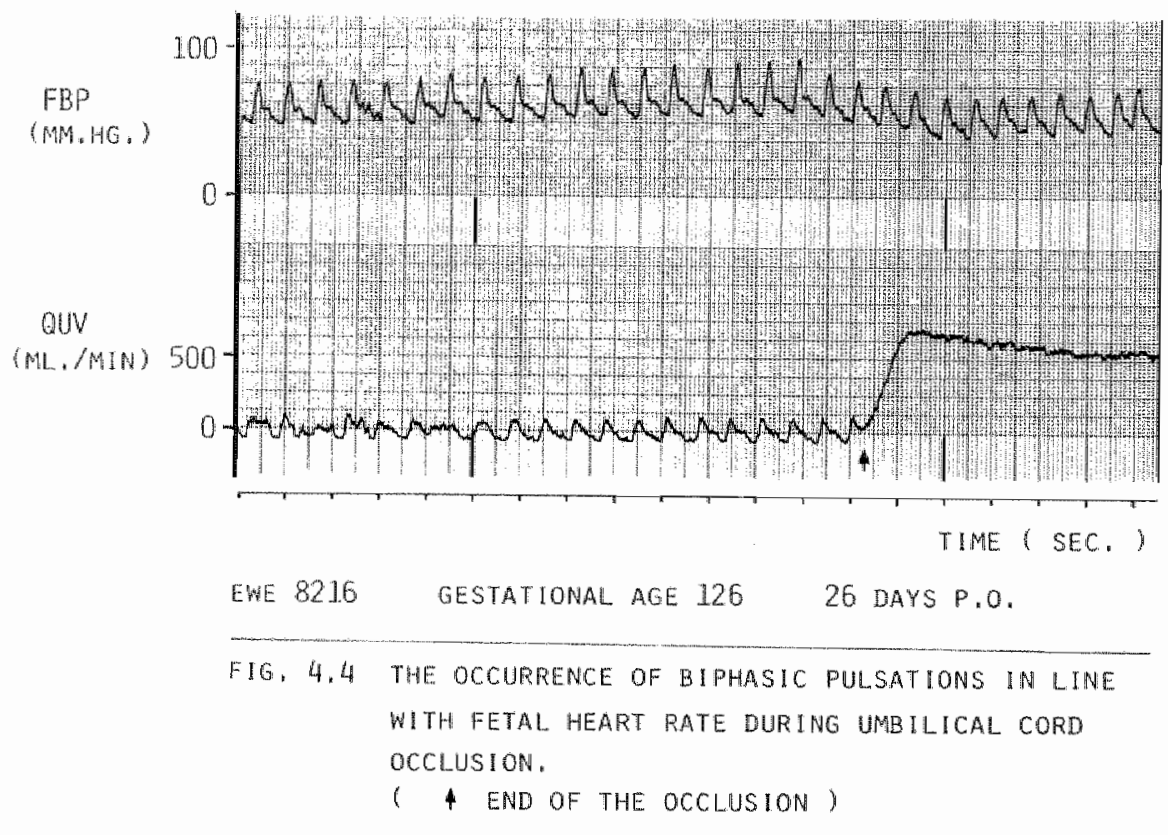

These venous pulsations were biphas1c with a systolic component occurring during ventricular systole and a diastolic component during ventmloular diastole. The systolic component started parallel with the 
arterlal pressure mise, peaked and decreased again, after which a second diastollc flow "surge" was seen much smaller in amplitude and occurring during ventrlcular diastole. Thereafter a nadir occured directly before the next rise in arterial blood pressure. During this nadir retrograde flow occurred in the experiments with complete blockade of umbllical venous blood flow.

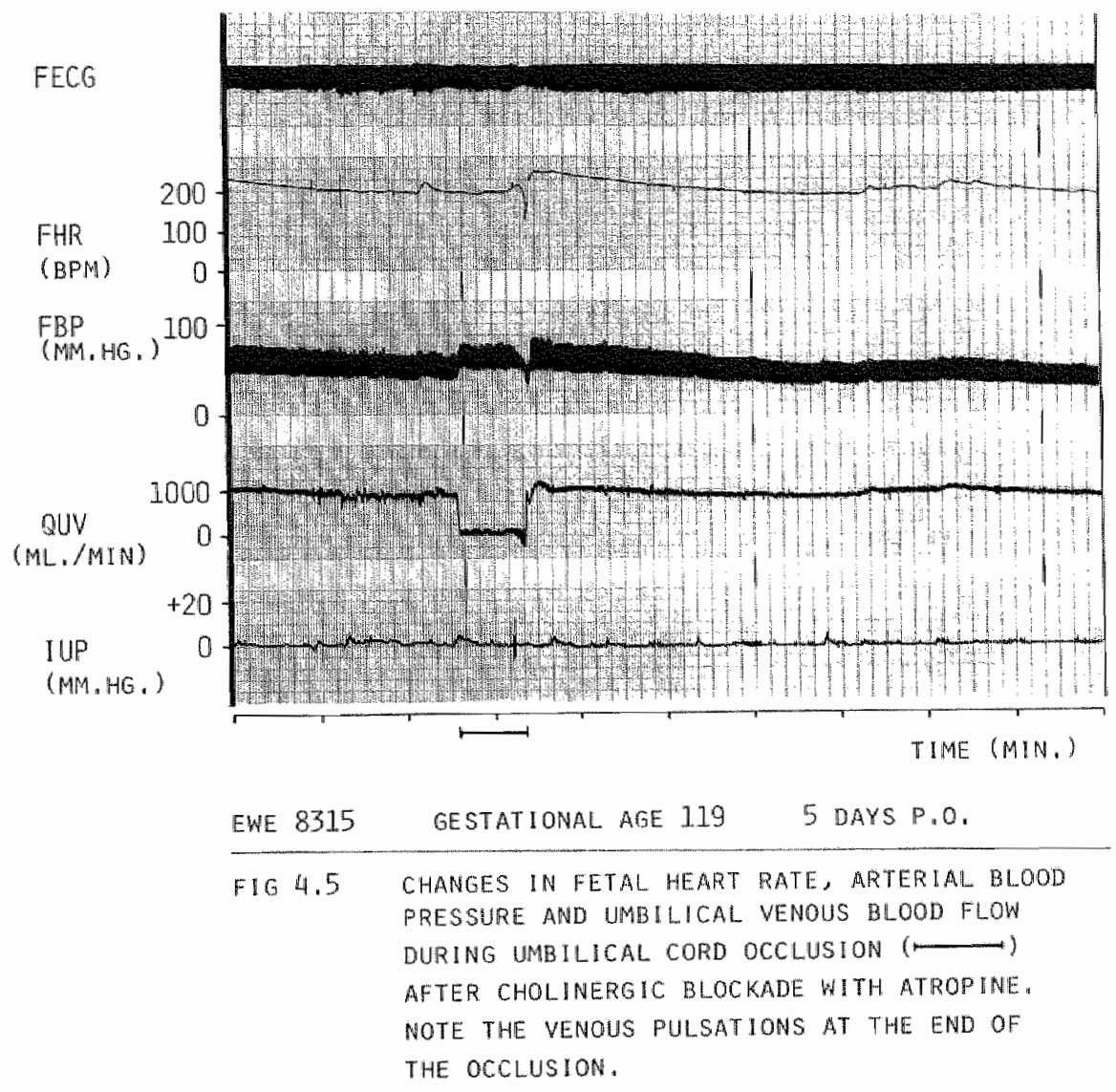


4.7.2 Selective blockade of the cholinergic, alpha-adrenergic and beta-audrenergle part of the autonomic nervous system

Cholinergic blockade with atropine (7 cord occlusions in 4 animals) prevented or diminished the f'etal heart rate deceleration during the cord acclusion, but did not preclude the occurrence of blphasic pullsations in the cormon umblilical vein flow (fig 4.5).

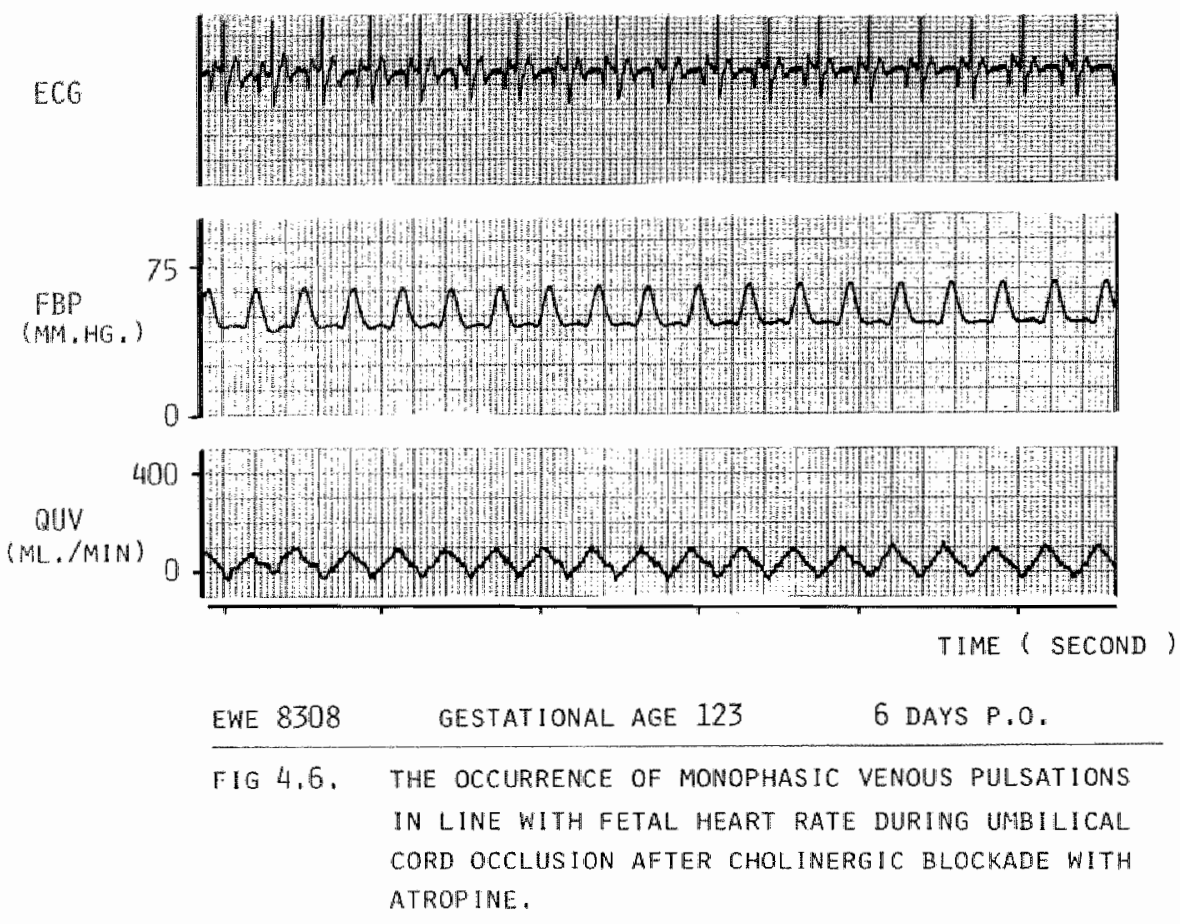

Fetal arterial blood pressure invariably increased during the occlusion with a gradually decrease to preocclusion values after the end of the occlusion.

Cholinergilc blockade did not preclude the occurrence of biphasic pulsations in the conmon umbllical vein, but their shape was monophasic Instead of biphastic ( $\mathrm{flg}$ 4.6). The diastolic component of the pulsation disappeared then. 


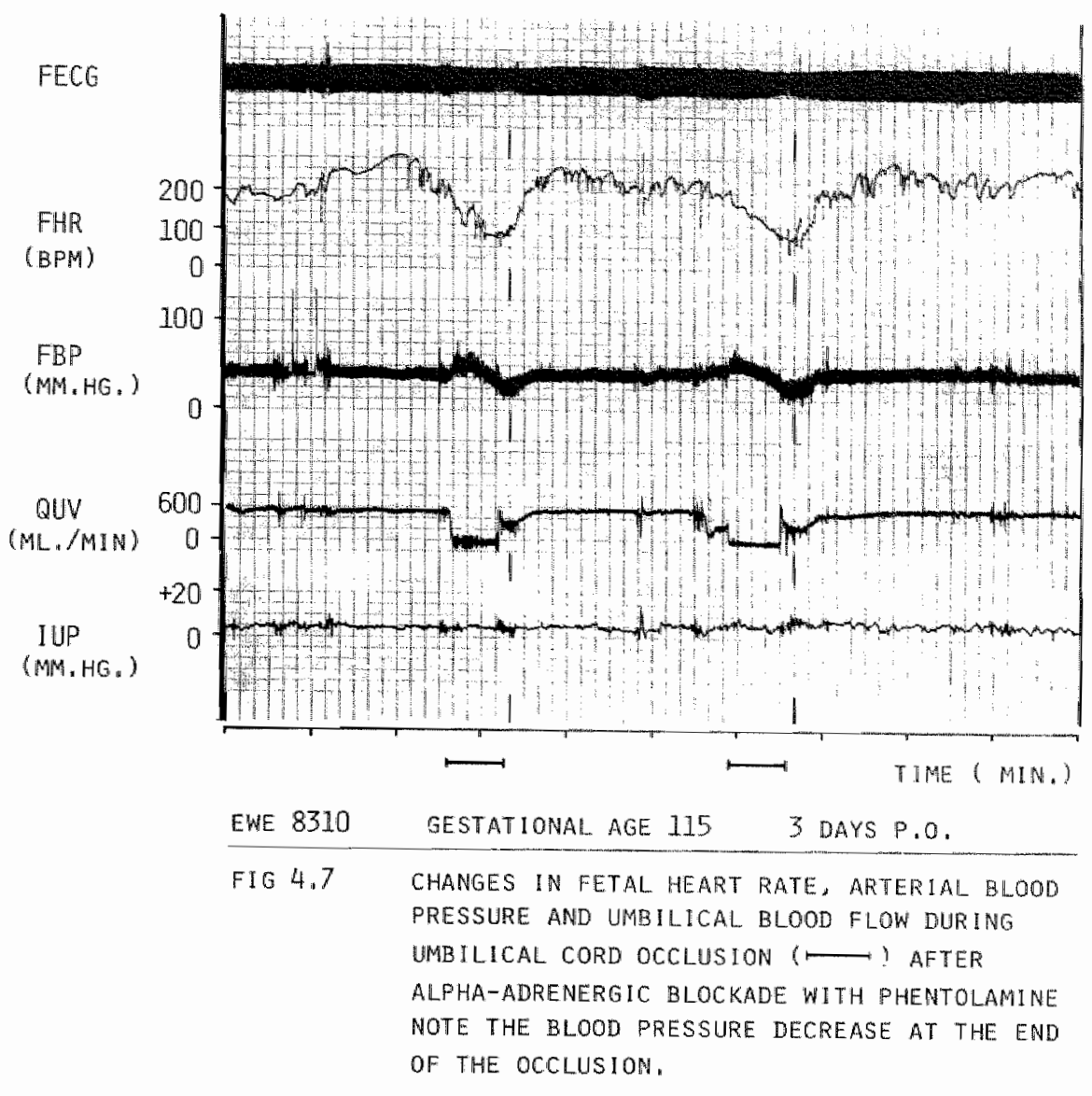

After alpha-adrenergic blockade with phentolamine (11 occlustons in it animals) an intlal rise in arterlal blood pressure was seen followed by a decrease in pressure during the latter part of the occlusion (flg 4.7). Fetal heart rate decreased during the occlusion.

The magnitude of the venous pulsations during umb111.cal cord occlusions after alpha-adrenergic blockade did not differ from their appearance in the unblocked condition. With regard to the shape of the blphasic pulsation however a shift in the proportion of the systollc and diastolic component of the pulsation was observed during the latter 
part of the occlusion when arterial blood pressure decreased. The alistolic component of the pulsation lncreased in amplitude at the cost of the amplitude of the systolic component (fig 4.8). This change in pattem of flow was only observed during a low arterial blood pressure.
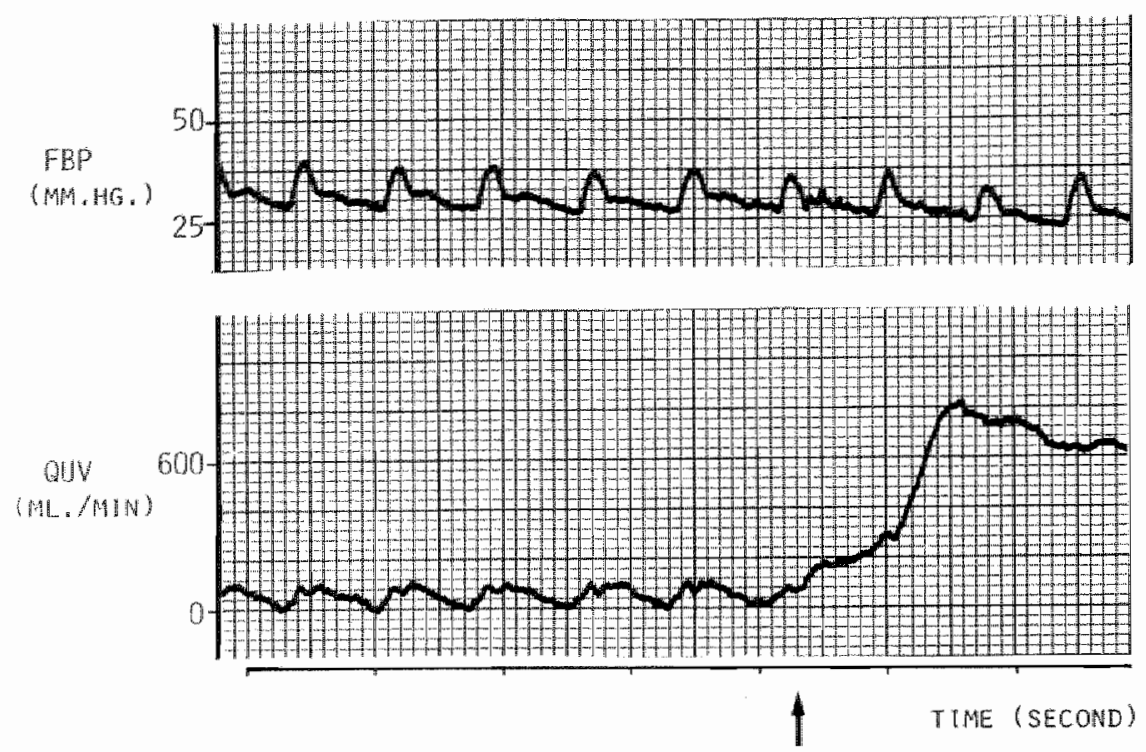

$\begin{array}{ll}\text { EWE } 8310 & \text { GESTATIONAL AGE } 115 \\ \text { FIG } 4.8 & \text { BIPHASIC PULSATIONS IN THE COMMON UMBILICAL } \\ & \text { WEIN FLOW PATTERN AT THE END OF AN UMBILICAL } \\ & \text { CORD OCCLUSION AFTER ALPHA-ADRENERGIC } \\ & \text { BLOCKADE WITH PHENTOLAMINE. THE DIASTOLIC } \\ & \text { COMPONENT OF THE PULSATION IS MORE PROMINENT } \\ & \text { THAN IN FIGURE 4.4.( HED OF OCCLUSION }\end{array}$

Umbllical cord occluston during beta-adrenergla blockade ( 8 occlusions In 4 animals) resulted In fetal bradycardla and hypertension. Fetal arrhythla with collapse of blood pressure often occurred in the latter part of the acclusions.

The pulsatile umbllical venous flow pattern durlng umblilcal cord occluslon after beta-adrenergle blockade was the same in magnitude and shape as during cord occlusion $1 \mathrm{n}$ the fetuses with an intact autonomic nervous system. 


\subsection{Discussion}

\subsubsection{Blood flow in the maternal internal 1llac and median uterine artery during umbilical cord compression}

The results from this study show that the maternal blood flow to the uterus is depressed during umbllical cord occlusion of short duration. The mechanism by which this decrease in maternal blood flow is brought about is not entirely clear.

The uterine circulation in pregnancy is considered as a low resistance, high flow vascular bed.

Minimal autoregulation of uteroplacental blood flow in response to changes in oxygen tension, carbon dioxide tension and perfusion pressure is present (Assali and Brinkman 1972, Clapp 1979) and a reduced uterine blood flow associated with a diminished oxygen uptake by the fetal blood can thus be ruled out as an explanation for this phenomenon.

Changes in perfusion pressure or autonomic tone of the uterine vascular bed also result in blood flow changes, but it is very unllkely that matermal hypotension would be responsible for the decrease in internal liliac and median uterine artery blood flow during umbilical cord compression. Changes in autononic tone of the uterine vascular bed, which is highly sensitive to alpha-adrenergic receptor stimulation on the other hand could be caused by catecholamines from fetal origin. Cottle et al (1982) suggested that fetal catecholamines released from the fetal adrenal medulla in response to hypoxemia (Comline et al 1965, Jones and Robinson 1975) and crossing the fetal matemal placental barrier, would at least be in part responsible for the reduced uterine blood flow during umblical cord occluston. He was the flrst one who observed maternal uterlne blood flow reductions durlng long lasting (4 min) partial occlusions of the umbillcal cord.

In a recent study however cottle et al (1983) found evidence that fetal catecholamines released in response to the hypoxemia caused by umbilical cord occlusion were not the major determinant of the uterine 
blood flow reductions Induced by cord occlusions. They found the same reductions in uterine blood flow during umblilcal cord occlusion with and without the previous administration of pronazine to the ewe. Promazine 1 s an antiemetic drug with alpha-adrenergic blocking properties and therefore capable of alpha-adrenergic blockade in the matemal placenta. If matemal uterine blood flow during umbilical cord occluston would have been malnly reduced by fetal catecholamines, then this reduction in flow should have been absent after maternal alphamadrenergic blockade, which was however not the case.

The results from this study also glve evidence that fetal catecholanines are not primarily involved in the mechanism of matemal flow reduction. Total umblilical cord occlusion namely reduces umbllical blood flow to zero thereby preventing fetal catecholamines to cross the placental barrier to the maternal side.

Furthemore one would have expected a sustalned reduction in matemal uterine blood flow after the end of the cord accluston, because of the relatively long lasting uterine vasoconstriction after alpha-adrenergic receptor stimulation.

The most likely explanation for the decrease in internal 1liac and median uterine artery blood flow durıng umbilical cord occlusion refers to an increased pressure in the fetal placental tissue leading to a decreased matemal flow by elevating the resistance in the matemal uterine circulation. An increase in tissue pressure and possibly tissue flutd formation could develop during the umbllical cord occlusion as follows: The umbillca]. veins will first be compressed during inflation of the balioon occluder. After a lag time of several seconds, necessary for the complete flliling of the balloon, the umbillical arteries are occluded too.

During this lag time the umbilical veins are completely compressed while the umbilical arterles are still totally or partially patent. A certain additional amount of arterlal blood w111 then be pumped into the unbllical circulation and will eventually be trapped in the unblilical vascular bed under a high pressure after complete compression of the umbilical arteries. The elevated fetal capillary pressure in the placenta leads then to an increased fetal placental tissue pressure whlich in turn compresses the matemal placental caplliarles resulting 
In an increased vascular resistance and a decrease in uterine blood Now.

The umbilical placental clroulation is capable of storing an extra amount of blood, which is shown in the study by de Haan et al (1979), who found that during selective acclusion of both umbillcal velns a slowly decreasing mean flow can be measured in the umbllical anterles durling the first seconds following the start of the occlusion. The results of a study by Jongsma et al (1979), In which an lncrease in placental blood volume of $34.8 \mathrm{ml}$ after clamplng of the umblifcal velns was found, are in favor of this hypothesis.

The results from this study are in agreement with the report by cottle et al (1982) who also found a decrease in the median uterine artery blood flow during long lasting ( 4 min) partial umblilcal cord occlusion.

The greater decrease in median uterine antery blood flow than in Internal 11 lac artery blood flow found in this study was in terms of percentage. The Plow decrease in absolute values was the same in both vessels. The difference in percentage change between the two vessels $1 \mathrm{~s}$ explatned by the fact that part of the internal 11lac artery blood llow 1s to non-uterine stmuctures (paragraph 2.4.1), which should not show any change in blood flow during umbllical cord occluston. It also makes clear why no changes in uterlne blood flow during umbllical cord occlusions were found in the study by Berman et al (1976). They measured the matemal blood flow in the midale sacral artery which in the nomenclature used in this study is known as the common intemal 11 ac artery. Thls vessel not only supplles the pregnant uterlne horn but also the non pregnant uterine hom, the presacral resion and other structures. It is concelvable that relatively small decreases in the blood flow in a part of the vascular bed of thls artery do not lead to statistically slgniflcant changes in the blood fllow of the common intemal 11lac artery, In which vessel the blood flow is much higher than in the median uterine artery. Another posslbility inlght be that relatively small increases in the resistance to flow in a part of the vascular bed of this artery might easily be accounted for by shifting blood to other vessels in such a degree that the mear flow in the 
comon Internal 11 lac artery is not affected.

It 1 s concluded from these results that uterine blood Plow is decreased durlng umbllical cord occlusion probably on the basis of an inoreased fetal placental tissue pressure.

\subsubsection{Instantaneous umbllical blood flow during occlusion of the umbilical cord in fetuses with an intact autonomic nervous system}

The nature of the blphaslc pulsations occurring in the common umbilical veln under varlous condtlons and thelr possible consequence for fetal hemodynamics in general will be discussed in chapter 5 .

The comment given here w111 therefore be restricted to this spectflc situation. Occlusion of the umblilcal cord is assoctated with an lincreased systemic arterlal pressure and peripheral vascular resistence. This tncrease in afterload augments the under nomal clrcumstances always present blphasic pulsations in the venae cavae (Reuss et al 1983).

The higher end-diastollc ventricular pressure associated with the Increase in pertpheral vascular resistance and arterlal blood pressure leads to an increased ventricular contraction force, resulting in a higher systollc component in the vena caval flow sumge (Reuss et al 1983). This explains why the systollc component of the biphasic pulsation in the comon umbilical vein $1 \mathrm{~s}$ also greater than the diastolle component.

The retrograde flow occurring with complete umblilcal cord occlusion durlng the deep through in between two blphaslc pulsations was also found by Reuss et al for the low pattern in the venae cavae during increased peripheral reslstance and artertal blood pressure assoclated with fetal hypoxemia.

Forward low in the venae cavae is normally impeded during atrial contraction. Conditions which result in an increase in atrial pressure as fetal bradycardia and increased ventricular afterload do, can eventually cause a retrograde flow in the venae cavae during atrial contraction.

Ihis flaw pattem is then reflected in the common umbilical vein after 
backward propagation.

4.8.3 Instantaneous umbilical blood flow durling occlusions of the umbilical cord after selctive blockade of the cholinergic, alpha-adrenergic and beta-adrenergic part of the autonomic system

The changes in heart rate and arterial blood pressure induced by umbilical cord occlusion during cholinerict, alpha-adrenergic respectively beta-adrenergic blockade have extensively been studled (de Haan et al 1976, 1979, Evers 1978). The data from the present study are in agreement with the results reported by them.

Cholinergic blockade prevented or diminished the heart rate deceleration associated with the umbilical cord occlusion. Higher heart rates shorten the diastalic fliling time of the right atrium with a diminishing diastolic component of forward flow in the venae cavae as result. Biphastc caval flow becones then monophastc (Reuss et al 1983), and the pulsations in the common umbilical vein, which are caused by backward propagation from the vena cava, follow this alteration.

Alpha-adrenergic blockade caused a blood pressure decrease in the latter part of the umbilical cord occlusion by preventing perlpheral vasoconstriction.

This reduction in afterload allows for greater ventricular emptying and a decrease in end-diastolic pressure. A greater diastolic flow surge in the caval velns then occurs (Reuss et al 1983).

This explains the relative Increase in the dlastolic flow component during the blood pressure decrease in the latter part of the umbllical. cord occlusion after alpha-adrenergic blockade.

Beta-adrenergic blockade with propranolol did not essentially change the fetal heart rate and blood pressure responses during umblilical cord occlusion except for the rhytrm disturbances.

No qualitative differences in the umbilical venous flow pattern changes during cord occlusions were therefore observed compared with the uniblocked condition.

The degree of fetal hypoxenla and acidemia caused by umbilical cord 
occlusion is of course out of proportion to the possible role of the assoclated relatively mall uterlne blood 1 low depression for fetal oxygenation.

It is however concelvable that the uterine flow decrease may adversely contribute to the development of fetal hypoxemla and acidemia, espectally during long lasting occlusions with a sustained depression of uterine blood flow (cottle et al 1982), in fetuses who are already severely compromised and in those situations in which the umblilical veln alone is regularly compressed.

On the other hand when considering the relatively great short-term variations that can occur in maternal uterine blood flow rate in response to changes in perfusion pressure, maternal cardiac output and autonomic tone (Clapp 1979), which variations were also observed in this study, then 1t is obvious that a great safety margin exists in the uterine flow rate before the fetus becomes endangered.

Moreover results from anlmal studies cannot be transposed to the human without restriction and one should be aware of the differences in anatomical structure between the ovine and human placenta, especially when fetomaternal placental relationships are concemed. 
GAPTER V

EFFECTS OF AGONISIS AND ANTAGONISTS OF THE AUTIONONIC NERVOUS SYSTEM ON FEIAL HEART RATE, ARTERIAL BLOOD PRESSURE AND THE BLOOD FLOW IN THE COMON UNBILICAL VEIN

\subsection{Introduction}

After the umbilical velns enter the fetal body, they fuse to form the common Intraabdominal umblical veln, through which vessel well oxygenated blood from the placenta reaches the fetus. Part of the unbilical venous blood flow is destined for liver blood supply, while the remainder (53\% according to Edelstone et al 1978) passes through the ductus venosus Arant11.

The ductus venosus Arantil is one of the circulatory shunts unique to the fetus that connects the common umbilical vein with the inferior vena cava: umbilical venous blood flow accounts for more than $95 \%$ of ductus venosus blood flow, the rest is supplied by portal blood (Edelstone et al 1978, 1980a).

From the inferior vena cava umblilical venous blood flow is transported elther through the right atrium to the right ventricle or through the foramen ovale to the left atrium and left ventricte. The arterlal circulation distributes this oxygenated blood then to the fetal ongans. After the entrance of the ductus venosus with 1 ts well oxygenated blood into the inferior vena cava with poorly oxygenated blood from the lower part of the fetal body, their flows do not mix evenly in the nomoxemic fetus but a certain preferential streaming exists.

The implications of streaming of venous blood are important in the fetus with its special anatomic connections that allow mixing of well oxygenated umbilical venous blood with poorly oxygenated systemic venous blood. Streaming occurs in the thoracic infertor vena cava of 
fetal monkeys (Behman et al 1970) and lambs (Edelstone and Rudolph 1979). Well oxygenated ductus venosus bilood is preferentlaily delivered to the brain and myocardium in both specles, as compamed to distal Infertor vene caval blood. Streaming of blood in the right atrium occurs in such a way that superior vena caval blood passes through the lght atrium malniy to the rigt ventricle, whereas inferior vena caval. blood, which contalns well oxygenated umbllical venous blood, passes both to the right ventricle and through the foramen ovale to the left atrium and left ventricle (Rudolph and Heymann 1967).

The unbllical venous part of the thoracic inferior vena caval flow streams prefementially through the foramen ovale to the left atrium and left vertricle, whereas the poorly oxygenated alstal inferior vena caval blood passes preferably through the trlcuspla valve (Edelstone and Rudolph 1979, Reuss et al 1981). During fetal hypoxemia however Reuss ot al (1981) found a slgniflcant decrease in preferentlal streaming. They attributed this decrease in preference to the pulsatile flow pattern in the vena cava.

The flow pattern in both superior and Inferior vena cava is pulsatile with two forward surges of blood flow durlng ventricular systole and diastole and the interisty of the caval pulsations is enhanced during fetal hypoxla (Reuss et al 1983). Th1s increased amplitude of pulsations might disrupt streaming and enhance mixing of ductus venosus blood with 1nferlor vena cava blood. A.though this intermption of preferentlal streaming may lead to the flow of less oxygenated blood to the left heart via the foramen ovale and therefore may impair oxygen delivery to the braln and myocardium, thls is well compensated for by two mechantams.

F1rst, there is an increase in the percentage of umbliloal venous flow that bypasses the liver through the ductus venosus, causing the proportion of umbl11cal venous blood contributing to the fetal cardlac output to lncrease from 27\% during normoxemla to 39\% during hypoxemla (Reuss and Rudolph 1980).

Secondly, a redistribution of cardiac output accurs during hypoxemla in fetal sheep with an Increase in flow to the brain and even more to the myocardium, thereby guaranteelng oxygen delivery to these organs (Peeters 1978, Reuss and Rudolph 1980). 
It was show by Reuss et al (1983) that changes in heart rate, ventricular afterload and the volumes of blood returning to the heart altered the flow pattern in the venae cavae. The afore-mentioned changes were induced by administration of various autonomic acting agents and by causing fetal hypoxemia, factors that interact with systemic and umbilical-placental vascular resistance. It was concluded by Reuss et al (1983) that these changes in the fetal systemic circulation caused alterations in fetal vena caval flow patterns and influenced the right atrioventricular fliling patterns.

It was suggested by them, based however on only one observation in a single fetus, that factors which increased pulsatility in the retal venae cavae might also influence the flow pattem in the conmon umbilical vein, which shows under normal conditions no or only minimal pulsations. We observed pulsatile flow patterns under various conditions in twelve fetal lambs (Hasaart and de Haan 1983, also paragraph 3.6 and 4.7 ).

To investigate the flow patterns in the comnon umblilcal vein, the effects of agonists and antagonists of the autonomic nervous system upon the instantaneous umbilical venous blood flow were studied.

Because the possible effects of these autonomic acting agents on the instantaneous umbilical venous blood flow pattern are closely related to their effects on the general circulation and must be fudged in connection with them, the influences of these agents on mean fetal heart rate, mean arterial blood pressure and mean unbilical venous blood flow were also studied. 


\subsection{Materlalis and methods}

The cholinerg1c, alpha-adrenerglc and beta-adrenergic parts of the autonomic nervous system (see also appendix) were blocked by adminlstration of respectively atropine, phentolamine and propranolol. Acetylchollne, norepinephrine and fenoterol were used as agonists of" respectlvely the chollnergic, alpha-adrenergle and beta-adrenerglic part of" the autononde nervous systern.

The effects of these arugs on fetal heart rate, arterial blood presisure and umblilcal venous blood flow were analyzed by comparing control data with values recorded at varying moments fmon the start of infusion of the drug to the fetus via the femoral artery catheter. All values were calculated over an interval of 10 seconds preceding the time moment deplcted in the tables. That is to say that the values shown at, e.g." 30 seconds were calculated over the interval from 20 to 30 seconds post Infusion. The same can be stated of the sampling interval of each other moment deploted in the tables.

The doses of the administered bolus infusions with acetylcholine, norepinephrine and fenoterol (table 2.7) were varled, in order to assess a possible different effect on instantaneous umbilical blood flow with different doses.

All data of the infusion experiments with each speciflc dmug were pooled irrespectively of the administered dose. The reasons therefore were threefold.

Firstly, only small quantitatlve and qualltatlve changes in mean fetal heart rate, mean arterial blood pressure and mean respectively Instantaneous umb1llcal venous blood flow were found with higher doses of acetylcholine and norepinephrine.

Secondly, the experiments were not directed upon the assessment of dose-response curves and thindly, the exact fetal welght at the time of the experiment was of course not known so that the interanimal. varlation in total administered dose has certalnly been considerable.

The W11coxon matched-palrs signed-ranks test was used for comparison of the parameters of the varlables. All p-values were calculated for two talled tests. Data are expressed as means $\pm S F M$.

The total number of observations at the varlous moments after the start 
of the Infusion is not always the same due to interferung factors, not allowing calculations at that particular moment.

\subsection{Results}

5.3.1 The effects of agonists and antagonists of the autonomlo: nervous systen on fetal heart rate arterlal blood pressure and mean umbllical venous blood flow

\subsubsection{Cholinergic blockade with atropine}

The effect of the administration of atropine on fetal heart rate, arterlal blood pressure and umbllical venous flow is shown in table 5.1. Seven studles were performed in six fletal lambs between 114 and 123 days gestation (mean $\pm \mathrm{SD}=118 \pm 1.8$ days) Mean fetal welght $\pm \mathrm{SD}$ at birth was $3000 \pm 28.5$ grams with a range from 1900 to 4100 grams.

\begin{tabular}{|c|c|c|c|c|c|c|}
\hline & $\begin{array}{l}\text { CONYROLL } \\
\text { A }=7\end{array}$ & $\begin{array}{l}30 \mathrm{SEC} \\
1=7\end{array}$ & $\begin{array}{l}60 \leqslant \mathrm{SE} \\
=7\end{array}$ & $\begin{array}{l}1.20 \mathrm{sEC} . \\
N=5\end{array}$ & $\begin{array}{l}180 \mathrm{SEC} \\
A=5\end{array}$ & 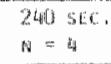 \\
\hline $\begin{array}{l}\text { FETALE HEAFT RATE } \\
(\text { BPFA })\end{array}$ & $259 \pm 4.6$ & $* 181 \pm 10.4$ & $-189+9.2$ & 27711.9 & $* 18517.3$ & $195+11.1$ \\
\hline $\begin{array}{l}\text { FETAL MATERIML } \\
\text { PEESSURE ( HAM HOS, }\end{array}$ & $40 \pm 2.5$ & $41 \pm 2.6$ & $43 \pm 2.9$ & $42 \pm 3.9$ & $4.123,7$ & 4455.0 \\
\hline 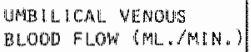 & $511 \pm 66$ & $-556 \pm 81$ & $546 \pm 80$ & $585+113$ & $569 \pm 101$ & $476 \pm 34$ \\
\hline
\end{tabular}

$$
* p<0.05
$$

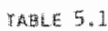

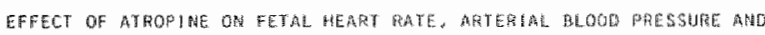

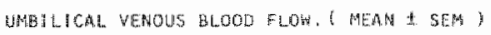

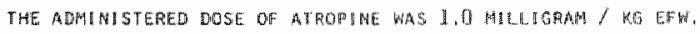

There was a significant increase in heart rate at 30,60 and 180 seconds after atropine administration. Mean fetal arterial blood pressure did not change significantly.

A small Increase in umbllical venous blood flow was found with a significant difference from control values only at 30 seconds post infusion. 


\subsubsection{Alpha-adrenergic blockade with phentolamine}

The effects of alpha-adrenergic blockade with phentolamine are show in table 5.2. Nine studies were performed in six fetal lambs between 115 and 138 days gestation (mean $\pm S D=123 \pm 3.1$ days). Mean fetal weight \pm SD at birth was $3000 \pm 28.5$ grams with a range from 1900 to 4100 grams.

\begin{tabular}{|c|c|c|c|c|c|}
\hline & $\begin{array}{l}\text { CONTROL } \\
N=9\end{array}$ & $\begin{array}{l}30 \text { SEC } \\
m=9\end{array}$ & $\begin{array}{l}60 \text { SEC. } \\
N=9\end{array}$ & $\begin{array}{l}120 \mathrm{sEC} \\
N=8\end{array}$ & $\begin{array}{l}180 \mathrm{SEC} \\
N=4\end{array}$ \\
\hline $\begin{array}{l}\text { FETAL HEART RATE } \\
\text { (EPHA })\end{array}$ & $174 \pm 7.9$ & $\star 212 \pm \pm 3.9$ & $188 \pm 14.2$ & $177 \pm 10.1$ & $180 \pm 17.2$ \\
\hline $\begin{array}{l}\text { PETAL ARTERIAL } \\
\text { PHESSURE (MM.HG.) }\end{array}$ & $40 \pm 4.3$ & $\star 34 \pm 3.4$ & $+31 \pm 3,4$ & $-31 \pm 3.2$ & $35 \pm 4.5$ \\
\hline $\begin{array}{l}\text { WHAB ILICAL VENDES } \\
\text { BLOOD FLOW } 6 \text { ML. IMUNH }\end{array}$ & $442 \pm 63.0$ & $415 \pm 62.9$ & $\star 346 \pm 51.0$ & $\star 335 \pm 60.8$ & $430 \pm 106.4$ \\
\hline
\end{tabular}

TABLE 5.2

EFFECT OF PHENTOLAMINE ON FETAL HEART RATE, ARTERIAL BLOOD PRESSURE AND UHBLILICAL VENOUS BLOOD FLOW. ( MEAN \# SEM I

THE ADMINISTERED DOSE OF PHENTOLAMINE WAS 2.5 MMLLIGRAM / KG EFW.

Heart rate increased significantly after 30 seconds and returned to control levels thereafter. Mean fetal arterlal blood pressure decreased significantly by $9 \mathrm{~mm} \mathrm{Hg}$ at 60 and 120 seconds post infusion.

Umbilical venous blood flow decreased significantly by $107 \mathrm{ml}$ at 120 seconds. The umbllical blood flow decrease was most marked with the lowest blood pressure measured.

\subsubsection{Beta-adrenergic blockade w1th propranolol}

The effects of propranolol on fetal heart rate, arterlal blood pressure and umbilical venous blood flow are listed in table 5.3. Seven studies were performed in five fetal lambs between 114-136 days gestation (Mean $\pm S D=121 \pm 2.8$ days $)$. Mean fetal weight $\pm S D$ at birth was $2780 \pm 26$ gram with a range from 1900 to 3600 grams.

After beta-adrenerglc blockade with propranolol a decrease in fetal 
heart rate of $38 \mathrm{bpm}$ was found at three minutes, whloh was however not statistically signiflcant, posslbly due to the small number of observations. Fetal arterial pressume showed no change.

Umbllical venous blood fllow declined to significantly different levels at two and three minutes from the start of the Infusion.

\begin{tabular}{|c|c|c|c|c|c|}
\hline & $\begin{array}{l}\text { CONTRDL } \\
N=7\end{array}$ & $\begin{array}{l}30 \leq \mathrm{SE} \\
\mathrm{H}_{\mathrm{N}}=7\end{array}$ & $\begin{array}{l}\text { Gu sec } \\
\text { St }=7\end{array}$ & $\begin{array}{l}1205 \mathrm{SEC} \\
\mathrm{N}=7\end{array}$ & $\begin{array}{l}1 \mathrm{SO} S \mathrm{SEC} \\
\mathrm{H}=7\end{array}$ \\
\hline $\begin{array}{l}\text { FETAL HEART RATE } \\
\text { ( BFW ) }\end{array}$ & $188+9,1$ & $177 \pm 2.8$ & $166+4.1$ & $159+6.8$ & $150 \pm 11.9$ \\
\hline $\begin{array}{l}\text { FETAL ARTERIAL } \\
\text { PRESSURE (MH./HG, }\end{array}$ & $38 \pm 2.6$ & $39+3,6$ & $38+2.6$ & $38+2.4$ & 3842,0 \\
\hline $\begin{array}{l}\text { UHARICAL VEMOUS } \\
\text { BLOOD FLOW (ML. /MIN, ) }\end{array}$ & $443 \pm 95.6$ & $423 \pm 89.6$ & $451+100.2$ & $+356 \pm 93.7$ & $+334+100$ \\
\hline
\end{tabular}

$\rightarrow P<0,015$

TABLE S. 3 .

EFFECT OF PTROPRANOLDL ON FETAL HEART RATE, ARTERIAL BIDOD PRESSURE AMD LMB ILICAL YENOUS GLOOD FLOW, ( WEAN \pm SENM)

THE ADMINISTERED DOSE OF PROPRAROLOL, HAS J.O MILLIGRAM / KG EFW.

\subsubsection{Cholinergic stimulation with acetylcholine}

The effects of the administration of acetylcholine on fetal heart rate, arterial blood pressure and umbilical venous blood flow are show in table 5.4. The varlables were analyzed starting directly arter the end of the administration, because of the imediate effect of acetylcholine when admintstered to the fetal arterlal clrculation.

Forty-flve experiments were performed in flve retal lambs between 117 and 142 days gestation (meam $\pm \mathrm{SD}=127 \pm 2.9$ days). Mean fetal welght + SD at birth was $3020 \pm 223$ grams with range from 2500 to 3600 grams.

There was a mall decrease in fetal heart rate of 6 bpm at 60 seconds, which was significant at the $p<0.05$ level. Acetyloholine resulted in a hlghly slgniflcant decline in arterlal blood pressure of 5 min $\mathrm{Hg}$ at 30 seconds, followed by a significant increase over control levels at 30 and 60 seconds after infusion of the drug. 
Umblical venous blood flow fell concomitantiy with fetal blood pressure by $22 \%$ or $129 \mathrm{ml} / \mathrm{min}$ at 10 seconds, followed by a recovery to control levels at 2 minutes. Figure 5.1 shows an example of a typical recording.

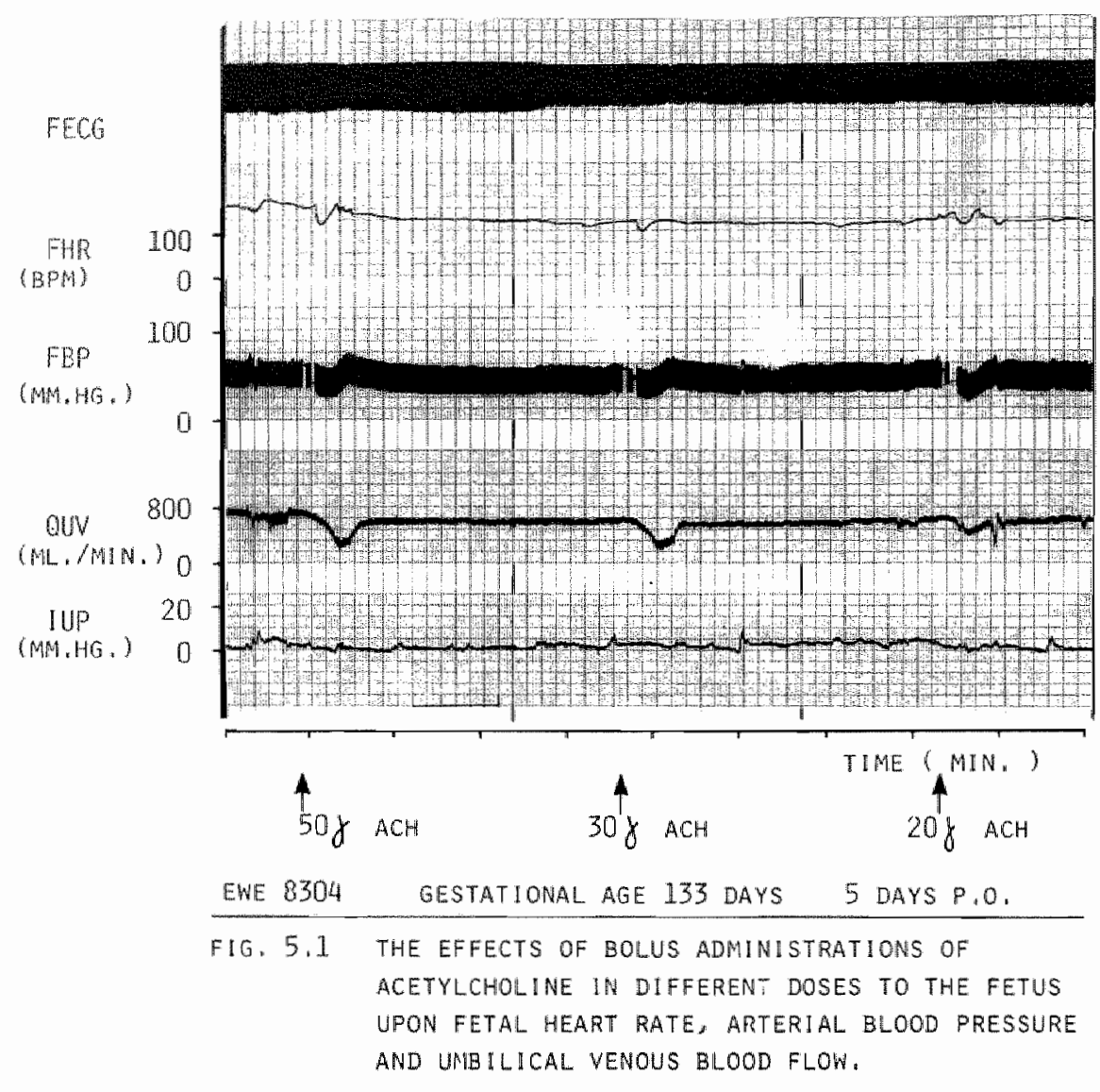




\begin{tabular}{|c|c|c|c|c|c|}
\hline & $\begin{array}{l}\text { COMTROL } \\
N=45\end{array}$ & $\begin{array}{l}30 \sec \\
N=45\end{array}$ & $\begin{array}{l}305 E C \\
N=45\end{array}$ & $\begin{array}{l}60 \mathrm{SEC} \\
\mathrm{HH}=4 \mathrm{H}\end{array}$ & $\begin{array}{l}120 \mathrm{SEc} \\
N=36\end{array}$ \\
\hline $\begin{array}{l}\text { FETAL MEABT RATE } \\
\text { (EPM) }\end{array}$ & $168 \pm 3.6$ & $173+4.1$ & $169 \pm 4.2$ & $162 \pm 3.1$ & $267 \pm 3,9$ \\
\hline $\begin{array}{l}\text { FETAL ARTERIAL } \\
\text { PRESSURE (MU, HW. }\end{array}$ & $39+1.3$ & $=34 \pm 1.4$ & $-42+1.2$ & 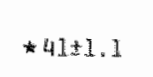 & $40 \pm 1.5$ \\
\hline $\begin{array}{l}\text { UHESLLAL WENOLS } \\
\text { DLOOD FLOW (ML/WIN, }\end{array}$ & $595 \times 46.5$ & $466+40.1$ & -525440.3 & $4562+42$ & $586 \pm 49.9$ \\
\hline$\star p<0.001$ & $P<0.05$ & & & & \\
\hline
\end{tabular}

TABLE 5.4

EFFECT OF ACETYLCHOLIME ON FETAL HEART RATE, FETAL ARTERIAL PRESSURE AND UMBILICAL VENOUS BLOOD FLOW, ( MEAN I SEM )

THE ADMIMISTERED DOSES OF ACETYLCHOLINE VAFIED FROM 5 TO 25 MICROGRAH / KG EFW.

\subsubsection{Alpha-adrenergic stimulation with norepinephrine}

The effect of administration of norepinephrine on fetal heart rate, artertal blood pressure and umbilical venous flow is shown in table 5.5. Twenty-eight experiments were performed in seven fetal lanbs between 115 and 140 days gestation (mean $\pm S D=126 \pm 2.7$ days). Mean fetal welght $\pm S D$ at birth was $3028 \pm 27$ grans with a range from 2000 to 4100 grams.

Norepinephrine resulted in a marked significant decrease in the fetal. heart rate over the first three minutes after the infusion. This decrease in heart rate is a reflex bradycardia in answer to the Increased artertal blood pressure.

Arterial blood pressure showed an increase by $14 \mathrm{~mm} \mathrm{Hg}$ at 1 minute whereafter blood pressure slowly returned to 1 tis control level at 5 minutes.

Umbllical venous blood flow showed a slight decrease during the first three minutes followed by a small increase at 4 and 5 minutes after infusion, but these differences were not statistically signif'lcant. 
An example of the cardiovascular changes with noreplnephrine administration is depleted in figure 5.2.

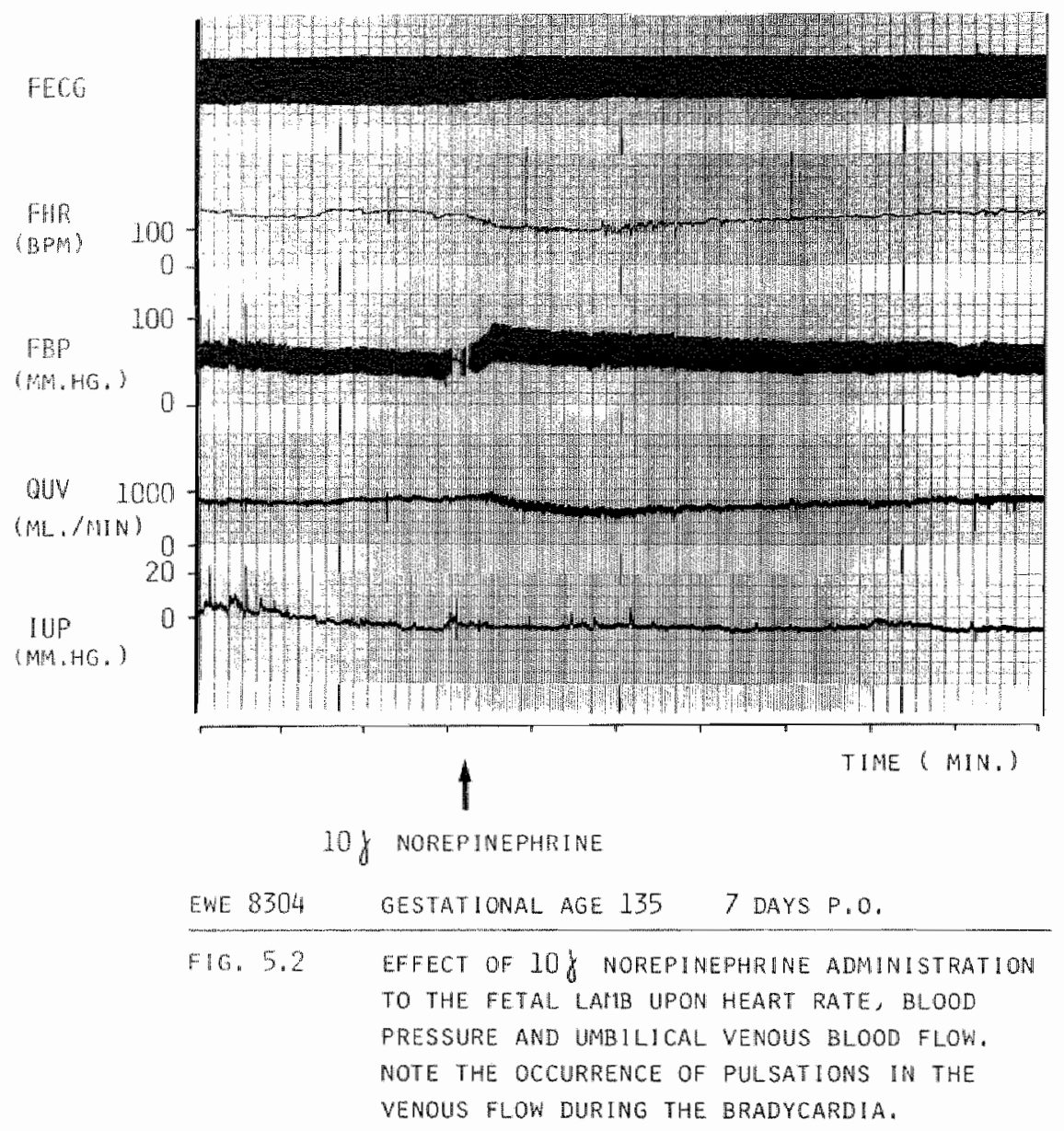




\begin{tabular}{|c|c|c|c|c|c|c|}
\hline & $\begin{array}{l}\text { Com } 106 \\
x=28\end{array}$ & 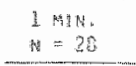 & 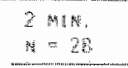 & $\begin{array}{l}3-10 \\
35-27\end{array}$ & 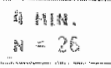 & $\begin{array}{l}310 \\
10\end{array}$ \\
\hline $\begin{array}{l}\text { FETAL HEAET RATE } \\
\text { C BFH }\end{array}$ & $169+4.8$ & 123247.9 & -14245 & 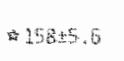 & 16958 & 13045 \\
\hline 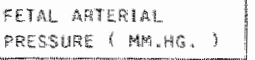 & $42+2,3$ & $96 \pm 5.2$ & 452,8 & $-49+2.7$ & 44524 & $44+2,3$ \\
\hline 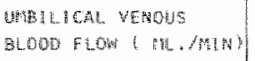 & $534 \div 2.9$ & $557+60.5$ & 56560,9 & 58949.3 & ongt? & $674+22,2$ \\
\hline
\end{tabular}

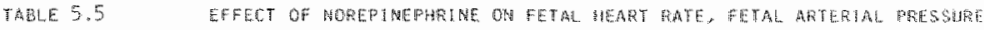

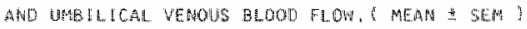

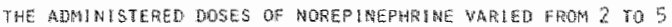

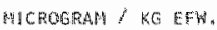

\subsubsection{Beta-adrenergic stimulation with fenoterol}

The effect of the administration of fenoterol on fetal heart rate, arterial blood pressure and umbilical venous flow is shown in table 5.6 .

\begin{tabular}{|c|c|c|c|c|c|c|}
\hline & $\begin{array}{l}\text { CONT ROL } \\
\text { N }=8\end{array}$ & $\begin{array}{l}1 F \| N, \\
N=B\end{array}$ & 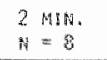 & 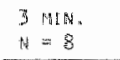 & 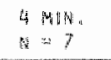 & $\begin{array}{l}54 ! m, \\
4=7\end{array}$ \\
\hline $\begin{array}{l}\text { FETHA HEMRT RATE } \\
\text { (EPH })\end{array}$ & $160 \pm 9.1$ & $175 \pm 10.4$ & $175+9.6$ & - 184470,9 & 173100,6 & $163+6, \alpha$ \\
\hline $\begin{array}{l}\text { FETAL AREARIAL } \\
\text { PRESSURE ( MHA HG, ) }\end{array}$ & 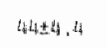 & $43,4: 3.8$ & $46 \pm 4,5$ & $45+3,9$ & $46 \pm 5,5$ & $4_{4}+4,1$ \\
\hline 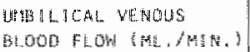 & $475+10,0$ & $473 \pm 11,8$ & 451830.9 & 401115,7 & 49.314 .64 & $4 x^{2}+4=1$ \\
\hline
\end{tabular}

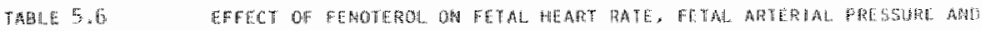

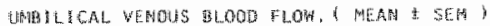

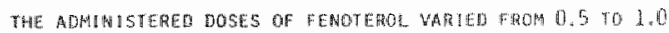

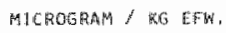

Eight experiments were performed in three fetal lambs between 117 and 130 days gestation (mean $\pm S . D=123 \pm 3.1$ days). Mean fetal welght \pm SD at blith was $3367 \pm 20$ grams with a range from 3300 to 4100 gramis. 
Fenoterol resulted only in a signiflcant increase in fetal heart rate of 18 bprin at 3 minutes. Arterial blood pressure and umbilical venous blood flow showed no signiflcant changes.

5.3 .2 The fiects of agonlsts and antagonists of the autonomic nervous system on the instantaneous blood flow pattern in the comon unbll1cal velin

Tnstantaneous unbllical venous blood flow showed in general no or only minimel pulsations without a recognizable pattem during the control reglstratons, umless fetal breathing movements were present which infuenced Instantaneous umb1l1cal venous flow as w111 de discussed in chapter 7 .

\subsubsection{Cholinergic blockade with atropine}

Wo changes were found in the instantaneous blood flow pattern of the comon umbilical vein after chollnerglc blackade with atropine (seven observations in six fetuses).

\subsubsection{Alpha-adrenerg1c blockade with phentolamine}

Administration of phentolamine to the fetus did not result in changes in the instantaneous blood flow pattern of the common umbllical vein (nine observations in six fetuses).

\subsubsection{Beta-adrenergic blockade w1th propranolol}

Also after propranolol infusion to the fetus no change in the instantaneous umbllical venous blood flow pattern was observed (seven observations in flve (etuses).

\subsubsection{Cholinergic stimulation with acetylcholine}

Administration of acetylcholine to the fetus resulted in a decrease in mean umblilcal venous blood flow and the occurrence of blphaslc venous 
pulsations in the Instantaneous blood flow in line with fetal heart rate (forty-flve observations in flve fetal lambs).

These pulsations consisted of two forward surges of venous blood, one occurring during ventricular systole and the second durlng ventricular diastole (flg. 5.3).

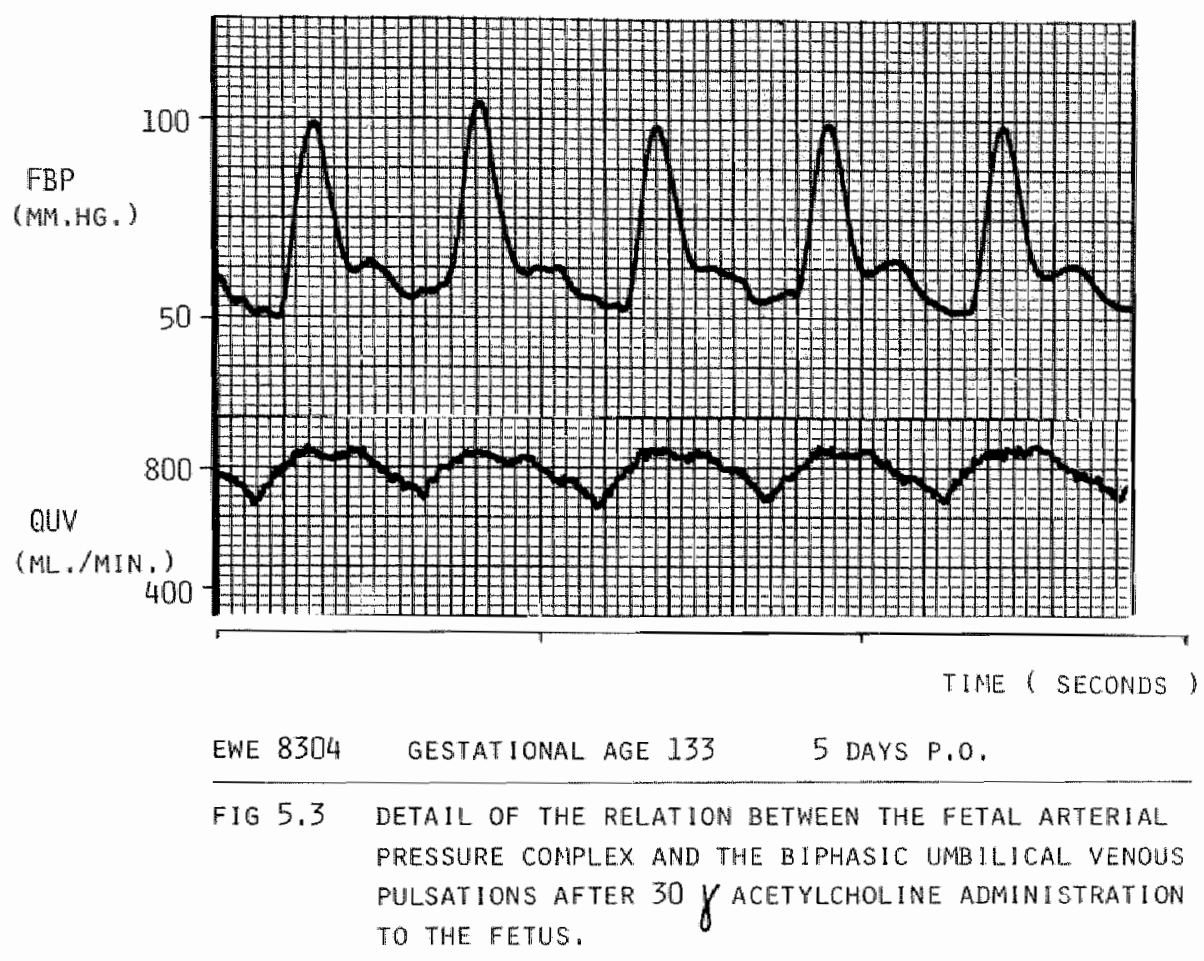

How began to increase just before the beginning of the arterial pressure rise in the aorta with a peak durlng ventricular systole. Then a small dip occurred followed by a second increase in flow after which the flow slowly decreased and a marked reduction in flow occurred just. before the beginning of the next ventricular systole. No clear difference was observed between the amplitude of the systolic and diastollc flow surge. The blphasic pulsations appeared when fllow and arterial blood pressure were already returning from their nadir towards 


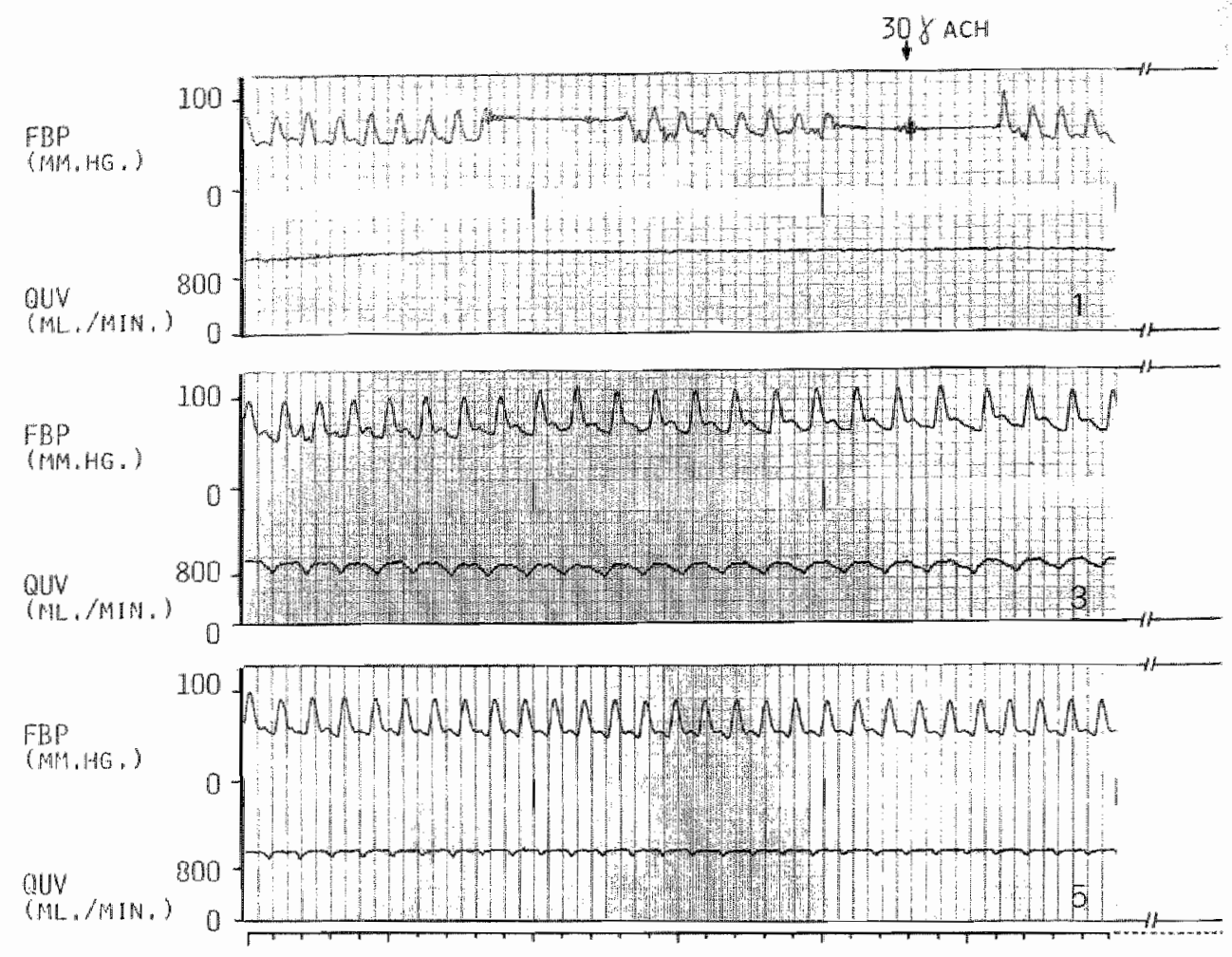

EVE 8304 GESTATIONAL AGE 142 14 DAYS $P_{\text {"O. }}$

FIG.5.4 THE OCCURRENCE OF BIPHASIC UMBILICAL VENOUS FLOW PULSATIONS IN LINE WITH FETAL HEART RATE AFTER ACETYLCHOLINE ADMINISTRATION TO THE FETUS. 

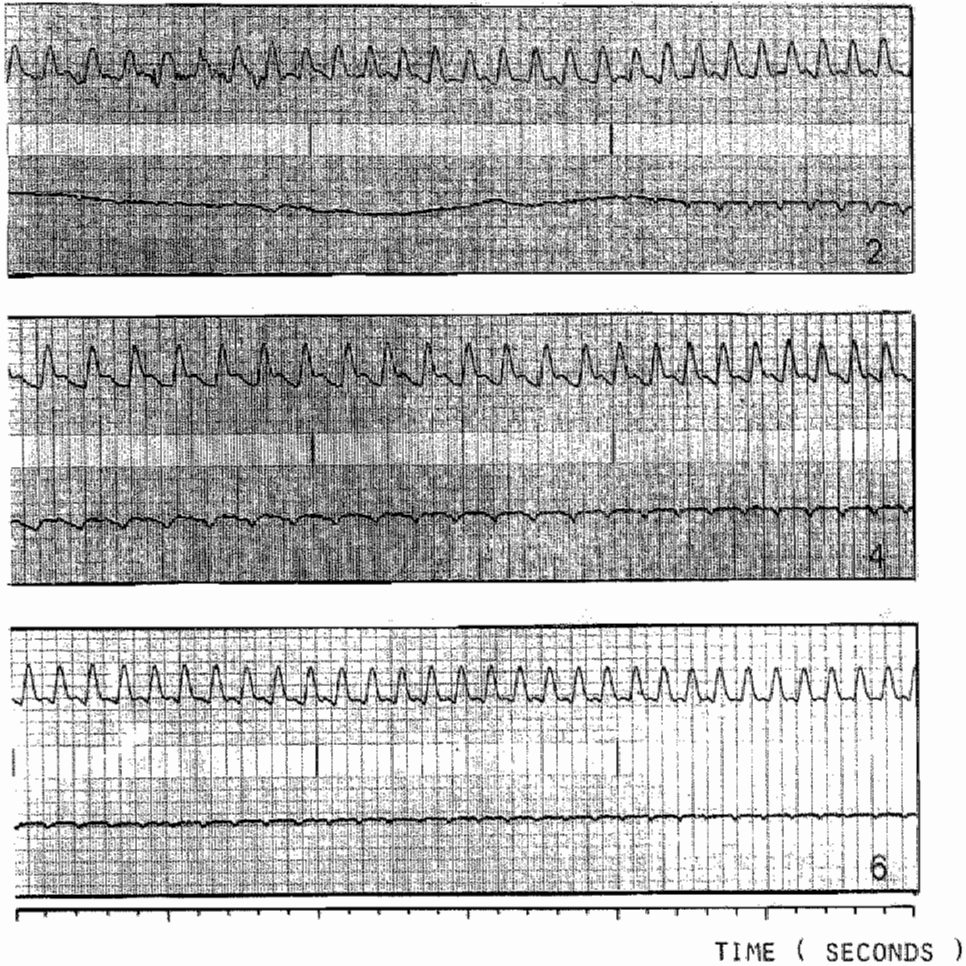

TIME (SECONDS ) 
nomal values Immedlately after the acetylchollne administration. They Increased in amplitude when fetal blood pressure began to rise above control values and gradually decreased and eventually disappeared as arterlal blood pressure decreased to control values (see fig 5.4). The amplitude of the pulsat1ons varled from small undulations to large blphaslc forms with higher doses of acetylcholine which caused more marked changes in arterial pressure and heart rate.

\subsubsection{Alpha-adrenergic stimulation with norepinephrine}

After administration of noreplnephrine to the fetus mean arterlal pressure rose and fetal heart rate fell. These changes were assoclated with the occurrence of biphasic flow patterns in the comon umbillcal venous blood flow whlch were in line wlth fetal heart rate. They also consisted of two small peaks during ventricular systole respectively dlastole as judged by the arterial pressure curve, although their amplitude was smaller than the pulsations assoclated with acetylcholine administration. No distinct difference between the two flow peaks could be observed. They increased in amplitude as fetal blood pressure rose and heart rate decreased and gradually disappeared with fetal blood pressure and heart rate returning to control values.

\subsubsection{Beta-adrenergic stimulation with fenoterol}

Fenoterol administration to the fetus did not result in any change in the instantaneous flow pattern in the comon umb1llcal vein. 


\subsection{Discussion}

5.4.1 Effect of autonomic antagonists on heart rate, blood pressure and mean umbilical venous blood flow

\subsubsection{Parasympathet1c blockade w1th atropine}

Parasympathetic blockade with atropine increased fetal heart rate. Th1s change was consistent with previous reported effects (Vapaavourd et al 1973, Nuwayhld et al 1975b, Evers 1978, Harris et al 1979, Edelstone et al 1980b, Rankin et al 1980). Mean arterlal blood pressure did not significantly change.

The increase in umbilical venous blood flow can be explained by the increased fetal heart rate after cholinergic blockade, since umbilical blood flow correlates positively with fetal heart rate and arterial blood pressure (Rudolph 1976). The increase in unbilical venous blood flow during cholinergic receptor blockade was therefore probably secondarlly caused by the increase in fetal heart rate rather than by a specific effect of parasympathetic blockade on the placental vessels or cormon umbilical veln.

This latter supposition could only be true if cholinergic receptors sites were present in the umbllical vein. No clear evidence however exists of vasonotor control of extracorporal foetal umbilical cord flow, whereas data from histochemical studies identifylng cholinergic neural fibers in the intraabdominal umbllical vein in man are conflicting. Ehinger et al (1968) recognized only adrenergic Imervation in the intraabdominal vein and in the ductus venosus in the human retus, whereas Pearson and Sauter (1969) found both cholinerglo and adrenergic nerve flbers.

An increase in umbllical venous flow after chollnergic blockade was also found by Edelstone et al. (1980b) and Rankin et al (1980) in a study with radioactive microspheres. Harris et al (1979) found a minimal nonsignificant increase in umbilical arterial blood flow after atropine administration to the fetus. 


\subsubsection{Alpha-adrenergic blockade with phentolamine}

The considerable decrease in blood pressure after alpha-adrenergic blockade with phentolamine was accompanied by a fall in umbilical blood flow. The increase in fetal heart rate which was only noted imediately after the infusion of the drug might be regarded as a fetal compensatory mechanism for the ensued hypotension and decreased vascular resistance, but the direct sympathico-mimetic stimulating effect of phentolamine on cardiac tissue might also plays a role (Goodman and Gilman 1980).

The decrease in umbilical blood flow with a constant heart rate can be explained by the arterial hypotension. A change in umbilical placental resistance after alpha-adrenergic blockade could not be determined, because umbllical venous pressure was not measured. Edelstone et al (1980b) however showed that umbilical vascular resistance was not affected by alpha-adrenergic blockade with phentolamine. They found moreover no change in umbilical blood flow measured by means of the radloactive microsphere technique or in heart rate while mean arterlal blood pressure decreased only $3 \mathrm{~mm} \mathrm{Hg}$ in contrast to the observations ( $9 \mathrm{~mm} \mathrm{Hg}$ ) in this study.

Rankin and Phemetton (1978) also found no signiflcant influence on umbilical vascular resistance and placental umbilical blood flow measured w1th microspheres after alpha-adrenerg1c blockade with phenoxybenzamine. Mean arterial pressure decreased $2 \mathrm{~mm} \mathrm{Hg}$ in that study.

Vapaavouri at al (1973) measured a decrease of $7 \mathrm{~mm} \mathrm{Hg}$ in systollc blood pressure after phentolamine in near-term fetal lambs, while heart rate showed a delayed Increase of 15 to 80 beats $/ \mathrm{min}$. Nuwayhid et al (1975b) found a 26\% to 30\% decrease in mean arterial blood pressure, but no change in heart rate after phenoxybenzamine in fetal lambs, part of which were however studied under anesthesia. Chez et al (1978) found a $16 \%$ to $30 \%$ increase in fetal heart rate w1th no change in umblilcal venous blood flow and arterial blood pressure w1th phenoxybenzamine administration.

In the Irivestigations in which no change in umbilical blood flow was found, there was also a minor decrease in fetal arterial pressure. 
Direct administration of phentolamine into the fetal descending aorta via the femoral artery catheter as was done in this study might provoke a more immediate and extensive vasodilatation than after adininistration to the fetal venous circulation, as was done in the studies by Rankin and Phernetton (1978), Cher et al (1978) and Edelstone et al (1980b). Although the doses of phentolamine $(0.10$ to $0.12 \mathrm{mg} / \mathrm{kg}$ EFW) were much smaller in the study by Edelstone et al than in the present study (2.5 $\mathrm{mg} / \mathrm{kg}$ EFW), incomplete blockade was excluded by them by the absence of changes in heart rate or blood pressure in response to the agonist methoxamine. The Influences of a different gestational age can also be excluded as a cause for the difference in results since in all studies near-term fetuses were used.

It is very likely that the fall in umblical blood flow in the present study was caused by the considerable deorease in arterial blood pressure, although an increase in unbilical placental resistance cannot be excluded.

\subsubsection{Beta-adrenergic blockade w1th propranolol}

The decrease in fetal heart rate after beta-adrenergic blockade was of the same magnitude as that reported by Vapaavour1 et al (1973), Nuwayhid et al (1975a), Llanos et al (1980) and Cohn et al (1982), while Harris et al (1979) reported only half of the decline in heart rate. Continuous infusion of propranolol also decreased fetal heart rate, as was shown by Dakes et al (1976b) and Ayromlool (1983).

The absence of a blood pressure change 1 is in agreenent with the studles by Oakes et al (1976b), Harris et al (1979), Llanos et al (1980), Cohn et al (1982) and Ayromlool (1983).

The 20\% decrease in umbilical blood flow at 180 seconds is in agreenent with the results of Oakes et al (1976b) and cohn et al (1982) who also found slgniflcant decreases in umblilcal blood flow of respectively $19 \%$ and $10 \%$ after propranolol.

Harris et al (1979) also reported a decrease in umblilical blood flow, although nonsigniflcant, of 23\% after propranolol. No significant changes in umbilical vascular resistance were found in the study of Harris et al (1979), whereas oakes et al (1976b) and cohn et al (1982) 
reported an increase in umbilical vascular resistance of $25 \%$ respect1vely $11 \%$ above control values.

The decrease in umblilical bload flow after beta-adrenergic blockade in the present study can be explained for the greater part by the concomitant fall in heart rate, but an increase in umbilical vascular reststance can not be excluded from the present data and might add to the decrease in umbilical blood flow.

Oakea et al (1976b) suggested that basal flow in the umbllical vascular bed 1s affected by a tonic beta-adrenergic activity, which conclusion was based on the increased umblilcal vascular resistance after beta-adrenergic blockade.

Rudolph (1976) and Berman et al (1978) however pointed out that calculation of umbilical placental vascular resistance from the conventional formula based on the Polseulle equation (umbilical resistrance $=($ mean aortic - umbilical venous pressure) : umbilical blood flow) is not reliable if there are alterations in heart rate.

The present data do not allow a certain conclusion with respect to the presence of beta-adrenergic control of the umbilical circulation. If the umblilical clrculation is under control of the beta-adrenergic nervous system then the site of the varlable resistance must be located in the intracorporal sections of the umbilical circulation, as no anatomical or histochemical evidence exists of vasomotor control of the extracomporal umbillcal and placental vasculature. 
5.4 .2 Effect of agonists of the autonomic nervous system on heart rate, blood pressure and mean umbllical venous blood flow

\subsubsection{Cholinergic stimulation with acetylcholine}

The reduction in umbilical blood flow after cholinergic stimulation with acetylcholine resulted from the fall in arterial pressure, because acetylcholthe probably does not change umb111cal placental vascular resistance (Beman et al 1978).

The fall in arterlal blood pressure after acetylcholine is caused by two mechanisms. There is a reduction in the vascular resistance in the systemic circulation (Berman et al 1978), leading to hypotenslon with a secondary fall caused by the decrease in the pulmonary vascular pressure (Nuwayhld et al $1975 \mathrm{~b}$ ).

The fall in blood pressure and umbll1cal blood flow were more obvious with higher doses of acetylcholine (25 microgram/kg EFW), which result is in agreement with the flndings of Nuwayhid et al (1975b).

\subsubsection{Alpha-adrenergic stimulation with norepinephrine}

Noreplnephrine causes an increase in the peripheral resistance due to vasoconstriction.

The decrease in heart rate after norepinephrine administration is a reflex bradycardia caused by the increased arterial blood pressure and initiated via the baroreceptors.

The responsiveness of the placental clrculation in the near-tem sheep to alpha-adrenergic stimulation has been shown by Barrett et al (1972) and was subsequently confumed by other investigators (Rankin and Phernetton 1976, Chez et al 1978) 1nalcating the exlstence of functional alpha receptors in the placental vascular bed.

The small decrease in umbilical blood flow in the face of a sertous Increase in perfusion pressure and relatively mall decrease in heart rate found in this study suggests that umb110al vascular resistance increased. This cannot be further proven, because fetal venous pressure was not measured. Whether norepinephrine and related cathecholamines 
have a vasoconstricting effect on the umbllical circulation has been the whject of many discusslons in the llterature.

Novy et al (1974) found no change in umbilical placental vascular resistance after noreptnephrine ( 1 to $2 \mathrm{mLerogram} / \mathrm{kg}$ EFW).

Rankin and phemetton (1976) on the contrary found a $40 \%$ decrease in umbllical blood flow with a signiflcant increase in placental vascular reslatance with doses of 22 to 120 micrograms of norepinephrine $\mathrm{kg} / \mathrm{EHW}$. Berman et al (1978) stated that nomepinephrine (maximu total dose 2 microgram) altered umbllical blood flow secondary to changes in heart rate and placental perfusion pressure, but did not change unbllical placental vascular resistance. The1r calculations of vascular resistance were dome when there was no change in heart rate, because they questioned the validity of the Polseulile equation for the calculation of unbilical vascular resistance when there were changes in heart rate (Rudolph 1976, Beman et al 1978). The calculations of umb111cal, reslstance after norepinephrine administration were therefore done after flxing the heart rate by cholinerglc blockade with atroplne. Rankin et al (1980) questioned these results and they concluded from their experiments with intravenous administration of 50 micrograms norepinephrine per minute that fetal heart rate is not a major determinant of umblilcal blood flow and that high doses of noreplnephrine cause vasoconstriction of the placental vascular bed of the near-tem sheep fetus.

zink and wan Petten (1981) however found in a study done with radloactive microspheres that placental blood flow lncreased in proportion to the increment of arterlal pressure in the fetus, showing that the placental bed was not appreciably constricted by noreplnephrine in a dose of $1 \mathrm{microgram} / \mathrm{kg} / \mathrm{min}$.

Chez et al (1978) found a very small ( $66 \%$ decrease in umbillcal blood low with continuous infusion of $1 \mathrm{microgram} / \mathrm{kg} / \mathrm{mLn}$.

It can be Inferred from the above mentioned studies that the vasoconstrictive effects of norepinephrine are dose related. Low doses (1-2 microgram $\mathrm{Kg} / \mathrm{EW})$ cause only minimal changes in umbilical blood Ilow and placental vascular resistance, while higher doses ( $>20$ mllorogram $\mathrm{Kg} / \mathrm{EFW}$ ) constrict the umbllical circulation and cause an increase in umbllical vascular resistance. The results from this study 
Indicate that placental vascular resistance may be already increased with doses of $2-5 \mathrm{microgram} / \mathrm{KB}$ ERW.

\subsubsection{Beta-adrenerg1c stimulation with fenoterol}

Beta-adrenergic agonists have a stimulating effect on fetal heart rate without changes in arterial pressure after adminlstration to the lamb (Chez et al 1978). The umblilical vessels are under normal clrcunstances fully dilated and beta-receptor stimulation does not lead to a decrease in umbilical vascular resistance (Beman et al 1978). The increases in umblilical blood flow after beta-adrenergic arugs are therefore probably directly related to the associated increases in heart rate.

In the small number of experiments from this study no changes in blood pressure or umbllical blood flow were found after a bolus injection of fenoterol, but only a small increase in heart rate, which result was to be expected.

\subsubsection{Effect of agonists and antagonists of the autonomic nervous system on the instantaneous blood flow pattern in the cormon umblilical vein}

Under nomal conditions biphasic pulsations in line w1th fetal heart rate are absent in the sheep fetus. This is in contrast to the flow pattern in both venae cavae in the fetal sheep, in which vessels blood flow is always pulsatile, inversely related to venous pressure and Influenced by the cardiac cycle and respiratory movements (Reuss et al 1983). These pulsations evidently are not blg enough under normal clrcumstances to be propagated via the ductus venosus to the common umbilical vein. Those conditions whlch Increase the pulsatility in the vena cava inferior as norepinephrine and acetylcholine administration (Reuss et al 1983) also provoke a biphasic pulsatile Flow pattern in line with fetal heart rate in the common umbilical vein. The cormon finding with norepinephrine and acetylcholine administration was a decrease in fetal heart rate. The pulsations intensified after acetylcholine administration in the cases with slower heart rates. Slower heart rates allow for a longer diastolic atrlal filling period 
with a more promlnent diastollo flow surge. This results in a higher atrlal pressure development with the next contraction, which might have In tum an Impeding effect on forward fow in the venae cavae leading to exaggerated blphaslc pulsations.

The same phenormenon occurs w1th norepinephrine. In contrast to the blphasic flow pattem in the venae cavae there was only a small dip in between the systolle and diastollc component of the flow surge and no change was found in the magnltude of the systollc flow surge after elther norepinephrine or acetylcholine. The flow pattern in the verae cavae showed an increased peak systolic flow after norepinephrine which Reuss et al (1983) explained by the Increase in afterload assoclated with peripheral vasoconstriction and increased systemic arterial pressure. Thls leads to a higher end-diastollc pressure and an increase in ventricular contraction force whlch in turn could increase peak systollc rlow.

The same mechanlisn is applicable to the increase in the diastollc component of the flow surge after acetylcholine. Acetylcholine reduces afterload by peripheral vasodllatation resulting in a greater ventricular emptying. Furthemore there is vasodilatation in the pulmonary vascular bed with acetylcholine (Nuwayhld et al 1975b) also allowlng a greater ventricular emptylng. End-diastolic atrial pressure is then reduced, permitting a greater diastolic flow surge.

The damplng of the pulse waves in the propagation circult from vena cava vla ductus venosus to common umbillcal veln is probably the reason that these differences in magnitude of the systolic and diastollc flow surges could not be seen in the flow pattern of the comon umblatcal veln.

It 1 s concluded from these results that blphaslc flow pulsations occur In the common umblilical veln under condltions which tncrease pulsat1lity in the venae cavae.

The Influences of alterations in vena cava flow patterns on right atrloventricular flliths patterns have been outlined by Reuss et al (1983).

It is very 1 ikely that flow pulsations in the comnon umbllical veln and thitus also in the ductus venosus can increase the degree of mixing of systemic inferior vena cava and placental ductus venosus blood and thus 
can Intermut preferential vena cava blood streaming leading to an alteration in the distribution of inferion vena cava blood in the fetal heart. 

CHAPTER VI

EFHECTS OF FENOIEROL, NOREP INEPHRTNE AND ACETYLCHOLINE INIUSION TO THE EWE ON MATERNAL PELVIC ARTERIAL AND FETAL UMBILICAL VANOUS BLOOD FLOW

\subsection{Introduction}

Since Barcmoft et al (1933) first measured uterine blood flow in the pregnant rabbit, a significant amount of quantitative and qualitative knowledge on blood flow to the gravid uterus has accumulated. Among the varlous adjustments that take place in the maternal organksm during pregnancy, the increase in matemal cardiac output and blood volume on the one hand and the rise in uterine blood flow on the other hand are considered to be of enomous importance for both the fetal and maternal. homeostasls.

The increase in maternal cardiac output and blood volume begins early in pregnancy and amounts up to $42 \%$ over control values during the last part of gestation in sheep (Clapp 1978). The development of the uteroplacental clrculation as a low resistance clrculatory network causes a nearly tenfold decrease in uterine vascular resistance in sheep (Assall and Brinkman 1972).

The overall. systemle vascular resistance of the mother falls approxlmately 30\% during pregnancy due to this low placental vascular. resistance. This decrease in the systemic vascular resistance helps to accomnodate the increase in matemal cardlec output. At term uterine blood flow comprises approxinately $80 \%$ of the pregnancy assoclated increase in cardlac output in the ewe (Clapp 1978).

In sheep, the uterine blood flow increases from about $1.5 \mathrm{ml} / \mathrm{min}$ per Kliogram of the ewe's welght in the nonpregnant state to about 17 $\mathrm{mil} / \mathrm{min}$ per k1logram of the ewe's welght near tem pregnancy (D1lts et all 1969). 
The mechands underlylng this massive sustained increase of uterine blood Plow occurring during pregnancy could be merely a consequence of the Increased cardlac output coupled with the development of the low resistance placental circulation, but there also might be active dilation of the uterine vasculature due to homonal, chemical or nervous influences from the autonomic nervous system.

Evidence exists that the sterolds oestrogen and progesterone influence the besal rate of uterlne blood flow and its distribution throughout pregnaricy in sheep (Rosenfeld et al 1975).

Support for the role of these sterolds can be found in the fluctuations in uterlne flow that accur in the cycling nonpregnant ewe, which reflect the cyclical homonal changes (Grelss and Anderson 1969).

These changes can be reproduced by the adminlstration of exogenous oestrogen and progesterone to the nonpregnant ewe (Greiss and Ander"son 1970, Caton et al 1974).

Exogenous oestrogens also cause an increase in uterine blood flow in pregrant ewes (Gre1ss and Marston 1965).

As in most blological systems, there 1 s not one single factor that regulates uterine blood flow, but thls flow must be seen as the end result of many influences which among them also comprise the prostaglandins and the renin-anglotensin system (Rankin and McLaughlin 1979).

Regarding the presence of autoregulation of the maternal placental blood flow, which term is used for the abllity of an organ to adjust and maintain its blood flow at a constant rate under chenging perfusing pressure through adjustment in the intrinsic vascular resistance, Gre1sis (1966), Ladner et al (1970), and Assall and Brinkman (1972) have demonstrated that in the near term pregnant sheep autoregulation is absent in the matemal uterlne circulation. Recent work by Grelss et al (1976) indicated howewer that autoregulation might be present in the myoendometrial or nonplacental vasculature but not in the placental cotyledons.

\subsection{Nomenclature of the arterial pelvic vasculature}

Blood flow measurements in the pelvic arterial bed of the ewe with 
electromagnetic flow transducers have been performed on varlous anatomical sites. The following vessels have been used for continuous flow measurements:

1. the cormon intemal or hypogastric illac artery

2. the internal 11lac or hypogastric artery

3. the main uterine artery

4. the middle or median uterine artery

The anatony of the distal aortic trifurcation with the nomenclature of these branches has been described in paragraph 2.4.1 ( $f 1 g$ 2.1). one should bear in mind the anatomical location of the flow transducers when comparing the results of different studies. In the following review of the ilterature on the effects of various autonomic acting drugs on the pelvic arterial flow, attention will be pald to the particular flow transducer sites.

\subsection{Blood flow responses of the maternal pelvic vascular bed to vasoactive stimuli}

\subsubsection{Alpha-adrenergic agents}

The effects of the catecholamines on uterine blood flow were flrst studied by Robson and Schild in 1938. They found that epinephrine produced arterial vasoconstriction in both pregnant cats and castrated cats treated with estrone or estrone and progesterone.

The vasoconstrictive effects of epinephrine were further conflirmed in pregnant dogs by Ailiquist and Woodbury (1947) and by Adams et al. (1961) in pregnant ewes.

Extensive studies into adrenergic influences on uterlne flow were done by Grelss et al in the sixtles and early seventles. They found that norepinephrine and eplnephrine caused a rnarked reduction in uterine blood flow during the last half of pregnancy after intravenous administration. This reduced uterine blood flow was almost exclusively due to increased vascular resistance with negligible changes in myometrial tension (Greiss 1963, Grelss and Pick 1964). Although his earlier studies indicated that only alpha adrenergic excltatory receptors were present in the ovine uterine vascular bed, later studies 
showed the presence of beta adrenergic receptors in the myoendometrial bed too (Grelss 1971, 1972), but no evidence for thelr existence in the placental bed was found.

ladner et al (1970) stimulated the alpha receptors in pregnant and nonpregnant ewes with intravenous and intraarterlal administration of noreplnephrine. They found a small increase in the flow of the median uterine artery with small Intravenous doses of norepinephrine 10.5 microgram/ $/ \mathrm{kg} / \mathrm{min}$ ) and a decrease with the larger doses. Direct intraarterlal infusion via the uterine artery caused an imnediate and striking iall in median uterine artery flow without slgnificant alterations in arterial pressure. This vasoconstrictive effect of noreptnephrine could be completely inhibited by the alpha blocker dibenzyline. The effects of norepinephrine were greater in nonpregnant than pregnant animals, which might be caused by a diminished alpha receptor activity during pregnancy related to the different hormonal environment.

Ladner et al (1970) ascribed the difference in response to vasoactive stimull between pregnant and nonpregnant animals to the presence of the placenta whlch acts as a low resistance system, dampening the cardiovascular responses.

Assall et al (1981) also found a greater vasoconstriction in the common Internal. 1llac artery in nonpregnant than in pregnant sheep upon Intravenous administration of norepinephrine via the jugular vein and intraarterial administration via the distal aorta. They ascribed this difference in part to the greater dilution of a glven dose of the drug In the greater blood volume in pregnant sheep, which would result in Lower plasma levels in pregnant than in nonpregnant animals.

Rosenfeld et al (1976) showed in a study with radioactive microspheres that the vasculature of all three uterine tissues (endometrium, myometrium and placental cotyledons) are sensitive to the vasoconstrictive effects of epinephrine.

The flow in the main uterine artery also decreased after intravenous norepinephrine administration (Chez et al 1978). The vasoconstrictive effect of endogenous catecholamines were studied by Shnider et al (1979) who measured median uterine artery flow and endogenous noreptnephrine plasma levels durting application of stressing stimuli to 
pregnant ewes. They concluded that maternal stress may decrease uterine flow secondary to release of endogenous noreplnephrine.

\subsubsection{Beta-adrenergic agents}

Beta-adrenergic agents with preferential beta 2 activity are widely used in human obstetrics mainly for treatment of premature labor. Several beta sympathlcomimetic drugs such as fenoterol, salbutamol, rltadnine, terbutaline and 1soxsuprine are nowadays avallable for tocolysis. They have in common assoclated cardiovascular and metabollc effects as wel1. In general they increase the maternal heart rate and decrease the maternal blood pressure and thelr use is accompanied by hyperglycemia. The magnitude of the cardiovascular effects vary with the drugs, which are infused. The effects of beta-adrenergic agents on uterine blood flow have been studied in several species including the pregnant sheep.

Greiss (1972) showed that beta-adrenergic meceptors are present in the uterlne vascular bed.

The group of Chez and Ehrenkranz studied uterine blood flow during continuous two hours intravenous administration of beta-mimetic arugs (Ehrenkranz et al 1976, 1977a, 1977b, Chez et al 1978). The uterine blood flow in their studies was measured with an electromagnetlic flow transducer around the main uterine artery. They found a marked decrease in uterine blood flow with isoxsuprine and ritodrine, a minimal decrease w1th salbutamol and no change w1th fenoteral.

Similarly, mean maternal arterial pressure moderately decreased with Isoxsuprine and ritodrine, decreased less wlth salbutamol and did not change with fenoterol. All four drugs were associated wth maternal. tachycardia. During the final 45 minutes of rltodrine amd salbutamol. Infusion to the ewe, uterine blood flow began to return to control levels, while mean matemal anterial pressure remalned decreased. Durlng the subsequent control pertod there was a slgnifloant hyperemia after unfusion of salbutamol and fenoterol, but not after mitodrine adininistration.

The inttial depression of uterine blood flow and mean arterial pressure associated with administration of ritodrine or salbutamol was found to 
abate with time desplte continued dmug infusion during prolonged infuglons of these drugs (Brennan et al 1977). An 1ncreased uterine vascular resistance was found with ritodrune while salbutanol and fenoterol decreased uterine vascular resistance (Brennan et al 1977). Wuwaybld et al (1980) studied the effect of continuous infusion of 1 soxsuprine and terbutaline on the flow in the matemal comon internal 11 lac artery and median uterine artery in pregnant ewes.

Both agents caused an Increase of the comon internal 11lac artery Plow, but Lsoxsuprine decreased the utertne artery flow slgniflcantIy, while terbutaline had only a mall decreasing effect on uterine artery frlow.

M1111ez et al (1981) reported no change in median uterine artery flow during terbutaline infusion in the same dose as used by Brennan et al $(0.40 \mathrm{microgram} / \mathrm{kg} / \mathrm{min}$ ) but in higher drug concentration $(0.80$ microgram $/ \mathrm{kg} / \mathrm{min}$ ) a decrease in uterine flow was found.

Ayromlool et al (1981) continuously infused isoxsuprine to pregnant ewes and found no slgniflcant change in median uterine artery flow. Simultaneous measurements of common internal 11 iac artery and uterine artery blood flow were performed by Tabsh et al (1981). They found an Inslgnificant effect on the common intemal 11lac artery blood flow but a decreased blood flow In the median uterlne artery during continuous 1soxsuprine Infusion to pregnant ewes. They concluded that these cont1guous vascular beds respond differently to isoxsuprine.

Erkkola et al (1981) stimulated beta-adrenergic receptors in the pelvic vascular bed of pregnant sheep by means of intraarterially administration of adrenergic drugs via a catheter located in the aortic trifurcation. Blood flow was measured in the comon Intermal 1liac and medlan uterine artery. After beta receptor stimulation w1th 1soproterenol a profound vasodilatation occurred in the tissues served by the common internal. 111ac artery w1th an increase in blood flow, whereas the flow in the median uterine artery sllghtly but consistently decreased. They concluded that stimulation of beta-adrenergic receptors produced active vasodilatation in extra-uterine vascular beds with minor changes in utertne blood flow of the pregnant horn. They supposed the changes in uterine blood flow observed durlng beta-adrenergic stimulation to be secondary and related to a shift of blood from the 
uterus to other vascular beds that were actively allated. Assall et al (1981) also found a consistent increase in blood flow in the common internal $111 \mathrm{ac}$ artery in response to intravenous 1soprotenerol administration. Matemal arterial pressure decreased and heart rate increased significantiy during the infusion period.

The confusion in the Ilterature regarding the effects of beta-adrenerglc drugs on uterine blood flow can thus partially be explained by the different anatomical locations at whlch blood rlow was measured by means of electromagnetic flow transducers. It 1 s furthemore obvlous that not all beta-adrenerglic drugs have the same effect on pelvic arterlal blood flow, probably due to differences in beta 1 and beta 2 activity as well as posslble alpha-adrenerglc and nonadrenergic effects. It is also clear from the above clted studies that the flow changes in the pelvlc vascular bed ellated by beta-adrenergic agents in pregnant sheep are dose related.

\subsubsection{Cholinergic agents}

Anlquist and Woadbury (1947) were among the flrst ones who reported Increased uterlne blood flow after acetylcholine administration to pregnant dogs and to dogs in the postpartum perlod. Greiss et al (1967c) showed that acetylcholine causes vasodilatation in the uterine vascular bed of the sheep, whlch effect was however many times greater In nonpregnant ewes than in pregnant ewes. Grelss measured the blood flow in the median uterine artery.

Assal1 et al (1981) reported that durlng intravenous administration of acetyloholtne to the ewe, common ll lac artery blood flow did not change slgmiflcantly in pregnant animals but increased to about $100 \%$ in the nompregnant sheep. After intraarterlal injection of acetylcholine Just above the aortic trifurcation, common 11 lac artery flow increased in both pregnant and nonpregmant ewes, but the Increment in the latter was slgnificantly greater than in the former.

This difference in reactivity between pregnant and nonpregnant sheep was attributed by them largely to the dilution of a given dose of the agent by the larger blood volume and blood flow that exist durlng pregnancy, rather than to the fact that the vessels were maximally 
dilated during pregnancy due to homonal influences.

Erkkola et al (1981) found that stimulation of chollnergic receptors by intraarterial acetylcholine administration produced active vasodilatation in extrauterine vascular beds with an increase in the comon internal 11 lac artery flow and only minor changes in uterine flow of the pregnant horm, as measured in the median uterine artery.

\subsection{Innervation of the uterine vascular bed}

The uterine arterles in the sheep are supplied with nerve fibers that enter the utemus with the vessels. The uterine arteries are extrenely sensitive to manipulation and they constrict intensively in the manipulated segnent. The spasm of these vessels can be released by infiltration of the adventitia with anesthetic solutions suggesting a neurogente nature of the vasoconstriction (Assal1 and Brinkman 1972). There is a great interspecles difference in the nature of the innervation of the uterine vessels, while in the same species the homonal status and gestational date also play a role in the degree of Innervation and neural excltablitty (Bell 1972, 1974). The possible Involvement of cholinergic vasodilator nerves in the maintenance of uterine blood flow in sheep was discounted by Greiss et al (1967c), because they were unable to produce increases in uterine blood flow by stimulation of elther sympathetic or parasympathetic roots (Grelss and Gobble 1967, Greiss et al 1967b).

Bell (1971) conflmed the absence of cholinergic vasomotor nerves at least to the parametrial vessels in the sheep histochemically. Evidence for adrenergic nerve fibers in the parametrial arteries of sheep is lindirect and not based on hlstochemical studies.

Grelss and Gobble (1967) found uterine vasoconstriction upon adrenergic sympathetic nerve stimulation in the pregnant sheep. The uterine vasculature reacts $w 1$ th a strong vasoconstriction upon alpha-adrenergic receptor" stimulation (Barton et al 1974).

Grelss (1972) found a difference in reactivity of the myoendometrial and placental vasculature upon alpha-adrenergic stimulation with a pronounced flow reducing effect in the myoendometrium and a much smaller Influence on the placental bed. 
Beta-adrenergic receptor stimulation had a signiflcant effect on myoendometrial vasculature, whlle no reaction in the placental vasculature occurred (Greiss 1971, 1972).

\subsection{Effects of maternal infusion with alpha-adrenergic, beta-adrenergic and cholinergic agents upon umbilical blood flow}

\subsubsection{Influences of alpha-adrenergic agents}

Chez et al (1978) found no change in umbilical venous blood flow upon maternal norepinephrine administration. Fetal arterial pressure mildiy Increased and fetal heart rate decreased. Wilkening et al (1982) also did not observe an appreciable effect on umbilical blood flow after uterine flow reduction by means of maternal norepinephrine infusion.

\subsubsection{Influences of beta-adrenergic agents}

The group of Chez and Ehrenkranz studied unblilical venous blood flow during matemal infusion with beta-adrenergic agents. They found a $15 \%$ increase above control in umbilical blood flow and a 50\% increase in heart rate during maternal isoproterenol infuston. Isoxsuprine adninistration was asssociated with a moderate fetal tachycardia and a slight increase in unbllical blood flow. There were no slgnjficant changes in umbilical blood flow, mean fetal artertal pressure or fetal heart rate with ritodrine, salbutamol or fenoterol. However, Incremental trends in both umbilical blood flow and fetall heart rate were observed when ritodrine or fenoterol were infused to the mother. But these trends were not significant because of inconsistency and varlability from one fetus to another and the relatively snall total number of animals (Ehrenkranz et al 1976, 1977a, $1977 \mathrm{~b}$, Chez et al 1978). Breman et al (1977) found an increase in umbillcal flow during long lasting maternal Infusions with ritodrine and no signiflicant change with fenoterol and salbutamol. 


\subsubsection{Influence of acetylcholine}

No data exist to our knowledge on potential effects of matemal acetylcholine infusion on fetal umbilical blood flow.

\subsection{Aim of the Irvestlgation}

Aim of this part of the study was first to assess whether the vascular bed supplied by the internal 111 ac artery and the medlan uterine artery reacted with flow changes during matemal intravenous administration of adrenerg $1 c$ and cholinerg $1 c$ agonists. Secondly whether any difference in flow reactions between those two vascular beds existed during adrenergic and cholinergic receptor stimulation.

The fetal part encompasses the possible changes in fetal heart rate, arterial blood pressure, umbllical venous blood flow and actd-base balance during induced changes in matemal pelvic blood flow. 


\subsection{Materials and methods}

Fifty eight matemal infusion experiments were performed in twelve animals. The infusion protocol for each drug has been described in paragraph 2.10.5.1, whereas the doses and infusion times of fenoterol, norepinephrine and acetylcholine are shown in table 2.10.

Mean values of matemal internal illac and median uterine artery blood flow and fetal umblilical venous biood flow, heart rate and arterlal blood pressure were calculated over intervals of five minutes. These Intervals comprised a five minute period during the control period $(=\mathrm{C})$ preceding the start of the drug infuston and in case of an infusion with acetylcholine or norepinephrine the last flve minutes of each sequential infusion period of fifteen minutes" duration.

The fetal and maternal parameters were therefore calculated during the Infusion with acetylcholine or noreptnephrine over the intervals 10 to $15(=15), 25$ to $30(=30), 40$ to $45(=45)$ and 55 to $60(=60)$ minutes after the start of the infusion. During the thirty minute recovery period they were calculated over the Intervals 70 to $75(=75)$ and 85 to 90 (=90) minutes after the beginning of the infusion.

Other intervals were chosen to analyse the effects of the fenoterol. infusions. Data were calculated over a five minute interval in the control period and during the last five minutes of both thirty minute Infusion periods and of the thirty minute recovery period. Consequentiy the following Intervals during infusion and recovery perlod were analysed: the intervals 25 to $30(=30), 45$ to $60 \quad(=60)$ and 85 to 90 (=90) minutes after the start of the infusion.

Fetal heart rate and arterial blood pressure were recorded in every single experiment, but arterlal blood pressure could not be analysed in all experiments due to interference by blood sampling procedures or technical problems. Thts explalns the difference in the number of fetal heart rate and arterlal blood pressure analyses in the varlous experiments, mentioned in the tables. The distribution of the fetal and maternal blood flow measurements for each drug are given in table 2.9. Fetal pH and blood gas values were determined during the control perlod $(=c)$, and at the end of the infusion $(=60)$ and recovery period $(=90)$. Statistical analysis was perfomed by comparing the control values with 
the data of the test and recovery perlod by means of Wilcoxon's matched-palrs algned-ranks test. The Petal blochemlcal data were analysed by a paired student's twest.

\subsection{Results}

Large diferences in absolute blood flow in the intemal 11lac and median uterlne artery existed between different animals at the same period of gestation. Internal $111 \mathrm{ac}$ artery blood flow vamied at 120 days gestation between 380 and $675 \mathrm{ml} / \mathrm{min}$ in different animals, and median uterine artery blood flow ranged at the same time of gestation from 150 to $420 \mathrm{ml} / \mathrm{min}$ in different animals.

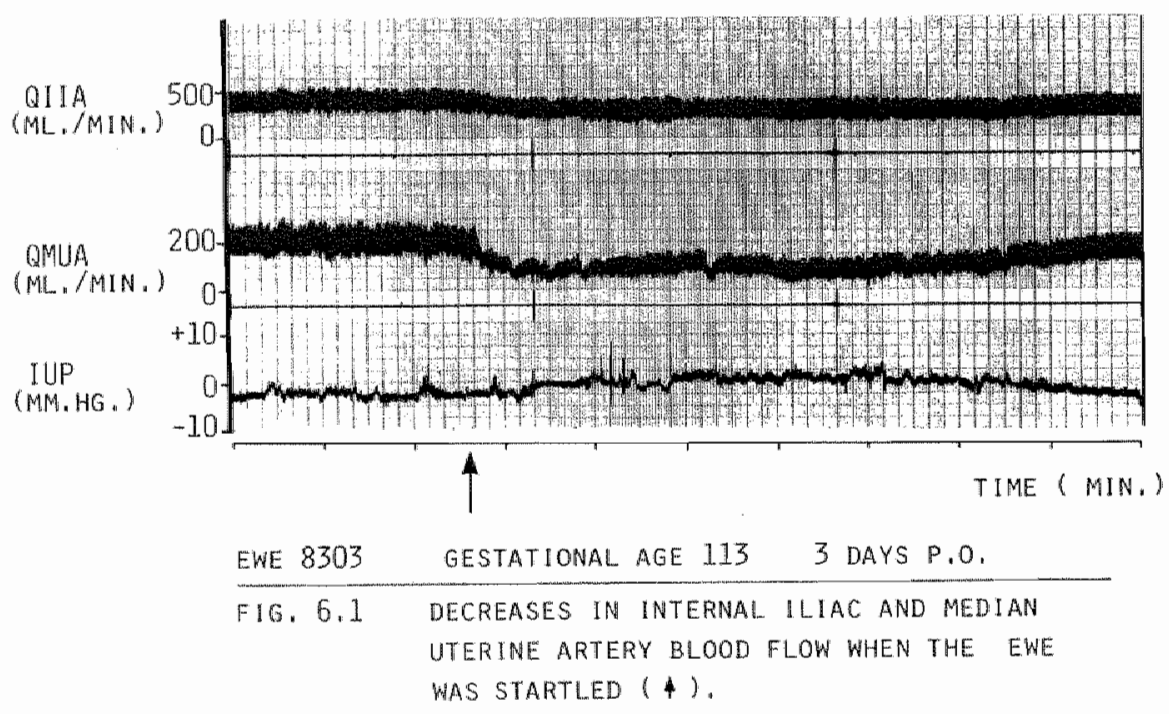

Short term varlations of often conslderable magnitude occurred in the maternal pelw1c blood flow. Apart from the influences of changes in cardiac output, arterlal blood presisure and heart rate, which were not recorded, the effect of autonomic tone changes in maternal internal l.liac and median utertine artery blood flow is impresivive. This is 11lustrated by the abrupt and often prolonged decreases in blood flow 
sometimes occurring during micturitlon and defecation and also during moments when the ewe became relghtened by suaden unexpected movements of the Investigator (flg 6.1). Flgure 6.2 shows an example of the decreases in matemal blood flow during mlcturition.

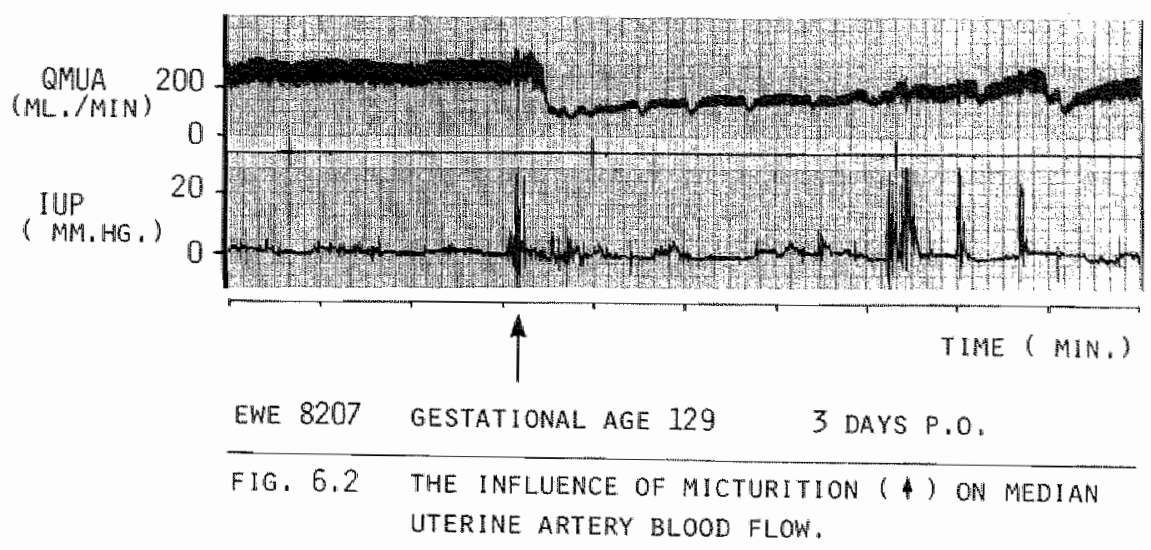

Minor variations in blood flow were observed durlng postural changes of the ewe. There was a possible small increase in mean blood flow after a postural change from the standing to a lylng position. Blood flow in different maternal positions was not further analysed in this study. Small short lasting decreases in median uterine artery blood Clow were also found during increases in uterlne tone, as reflected in the amiotic pressure. Regular contractions were absent durlng the experiments.

Dlsplacement of the flow transducers around the maternal vessels during e.g. micturition or maternal movements 1.3 a posslbie cause for the observed flow changes in the first days after implantation of the flow transducers. It is however unlikely that dlsplacement of the flow transducers occurred several days after operation, because they were found to be fimly attached to the vessel wall by adhesilons at that time.

The experiments with decreases in matemal blood rlow assoclated with micturition, defecation and fright were excluded from the study. 


\subsubsection{Effect of continuous administration of fenoterol to the ewe on the matemal and fetal parameters}

The mean blood flow in the internal illac artery increased during the Infusion period and was still elevated at the end of the thirty minute recovery perliod.

Only the $10.5 \%$ increase in blood flow at the end of the infusion period with 4 microgram per minute differed significantly (p<0.05) from control. The individual data of each experiment showed an increase in blood flow at the end of each infusion perlod in 9 experiments. Blood flow was lower than control value at the end of each infusion period in three experiments, whlle in the remalning three experiments the blood Low response was varying, that is to say either lower or higher than the control value at the end of both infusion pertods.

\begin{tabular}{|c|c|c|c|c|}
\hline & $60^{r}$ & $0^{\prime}$ & & \\
\hline FENOTEROL & CONTROL & $12 \gamma / M I N$. & $48 / M 1 N$ & RECOVERY \\
\hline $\begin{array}{l}\| F H R(B P M) \\
N=24\end{array}$ & $167 \pm 3,6$ & $163 \pm 3.2$ & $159 \pm 3.9$ & $164 \pm 3.5$ \\
\hline $\begin{array}{l}F B P(M M, H G \cdot) \\
N=21\end{array}$ & $36.3 \pm 11.9$ & $36.4 \pm 1.9$ & $36.3 \pm 2.1$ & $35.6 \pm 1.8$ \\
\hline $\begin{array}{l}\text { auv ( ML. } / \text { MIN, }) \\
\mathbb{N}=20\end{array}$ & $635 \pm 59$ & $631 \pm 51$ & $637 \pm 64$ & $628 \pm 59$ \\
\hline QIIA 15 & $389 \pm 50$ & $402 \pm 39$ & $430 \pm 59$ & $454 \pm 74$ \\
\hline $\begin{array}{l}\text { QMUA }(\text { NL. } / \text { MIN. }) \\
N=18\end{array}$ & $324 \pm 43$ & $331 \pm 46$ & $338 \pm 41$ & $317 * 43$ \\
\hline
\end{tabular}

$\operatorname{Ap}<0.02 \quad$ op $<0.05$

TAELE G.1 EFFECT OF CONTINOUS INTRAVENOUS ADMINISTRATION OF FENOTEROL TO THE EWE ON FETAL HEART RATE, ARTERIAL BLOOD PRESSURE, UMEILICAL VENOUS BLOOD FLOW AND MATERNAL INTERNAL ILIAC AND MEDIAN UTERINE ARTERY BLOOD FLOW. DATA ARE EXPRESSED AS MEAN I SEM, ( START OF THE INFUSION). 
Mean median uterine artery blood flow showed no signiflicant changes, although an incremental trend during the infuston perlod was found. Analysis of the Individual data of each experiment showed a consistent increase in blood flow at the end of each infusion period in 10 experiments. Blood flow was lower than the control value at the end of each infusion period in five experiments, while in the remalning three experiments the effect on blood flow was varying, namely either lower or higher than the control value at the end of both infusion periods. Fetal umbilical venous blood flow and artertal blood pressure did not change. Fetal heart rate showed no changes except for a slight decrease at the end of the infusion period ( $p<0.02)$. Table 6.1 shows the fetal and maternal parameters. The fetal $\mathrm{pH}$ and blood gas values are shown in table 6.2. Fetal $\mathrm{pCO}_{2}$ was signiflcantly $(p<0.005)$ reduced at the end of the infusion and recovery period. Fetal phi and $\mathrm{pO}_{2}$ did not signiflcantly change.

\begin{tabular}{|c|c|c|c|}
\hline FENOTEROL & C & $60 \mathrm{MIN}$. & $90 \mathrm{MIN}$. \\
\hline $\mathrm{PH}$ & $7,35 \pm 0,04$ & $7.36 \pm 0.04$ & $7.35 \pm 0.03$ \\
\hline $\mathrm{PCO}_{2}$ & $4.96 \pm 0.57$ & $4.67 \pm 0.61$ & $4.61 \pm 0.64$ \\
\hline $\mathrm{PO}_{2}$ & $3.57 \pm 0.44$ & $3.52 \pm 0.49$ & $3.59 \pm 0.53$ \\
\hline
\end{tabular}

$\star \mathrm{P} \quad<0.005$

TABLE 6.2 FETAL PH AND BLOOD GAS VALUES BEFORE, DURING AND AFTER THE ADMINISTRATION OF FENOTEROL TO THE EWE: ( $M E A N \pm S D ; N=24$ ). 
6.8 .2 Effect of continuous infusion of acetylcholine to the ewe on the matemal and fetal parameter:s

The mean blood slow in the intermal lilac artery did not change slgniflcantly during acetylcholine administration to the ewe. A small $(5.9 \%)$ but significant increase $(\mathrm{p}<0.05)$ in mean median uterine artery flow was found at the end of the first infusion period, but no slgntifleant changes occurred during the rest of the infusion perlad and thereafter (table 6.3).

\begin{tabular}{|c|c|c|c|c|c|c|c|}
\hline & $30^{\mu F}$ & 0 & $15^{\prime \prime}$ & $0^{83 x}$ & $5^{\prime \prime}$ & & \\
\hline ACETYCOOO I I & COHTROL & $20 \% \mathrm{KMH}$. & $506 / \mathrm{NAN}^{2}$ & 200 T / P I & 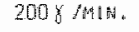 & \multicolumn{2}{|c|}{ RECOVERY. } \\
\hline 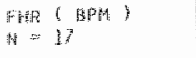 & $168+4.1$ & 16643.7 & $137+3.2$ & 16523.2 & $168=3,9$ & 17323.8 & $171044=4$ \\
\hline $\begin{array}{l}\text { FBP } 4 \text { Het. } 146.1 \\
M=15\end{array}$ & 40.912 .3 & 40.022 .9 & 41.332 .5 & $39.6+2.9$ & $4,1,6 \pm 3.5$ & 42.542 .7 & $40,1 \pm 2,0$ \\
\hline 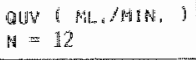 & $562+75$ & 591468 & $617+72$ & $508+73$ & 548471 & $562 \pm 85$ & $503: 90$ \\
\hline 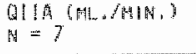 & $447 \pm 74$ & $431 \pm 87$ & $417 \pm 71$ & $4 \times 2 \pm 89$ & $433+98$ & $436 \pm 86$ & $446 \div: 34$ \\
\hline 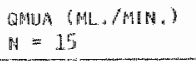 & 323444 & $342 \pm 47$ & $305+410$ & $320 \pm 16$ & $331+43$ & $318+41$ & $362 \div 444$ \\
\hline
\end{tabular}

TRE:E 6.3 EFFECT OF CORTIRUOUS INTRAVENOUS ADHUMISTRATIOW OF ACETYLOHOLIKE TO THE EWE ON FEYAL HEART RATE, ARTERIAL BLOOD PRESSURE, UMBHLICAL VEMLUS BLOOD FLON AHD MATERMAL INTERRARL ILIAC ANE MEDIAN UTERINE ARTERY BLOOD FLOW" DATA APEE EXPRESEED AS WEAMASEM ( START OF THE IMFUSION.

Analysis of the 1nd lidual data of each experiment showed in the seven cases wth Intemal 11lac artery blood flow measurement a consistent increase in blood flow in one experiment and consistent decrease in blood flow in two experiments at the end of each infusion perlod. In the remalning four experiments no consistent change was round: blood flow elther was lower or higher than the control value at the end of the infusion pertods.

The same pattem was observed in the individual reactions in the flfteen experiments in whlch the median uterine artery blood flow was measured. A consistent increase in blood flow occurred in five 
experiments and a consistent decrease in median uterine artery blood flow was seen in four experiments at the end of each infusion perlod. In the remaining six experiments median uterlme artery blood flow response was varying, that is to say elther lower or higher than the control, value at the end of the infusion periods.

Fetal heart rate, arterlal blood pressure and umbllical venous blood flow did not change throughout the Infuslon and recovery perlod. Fetal $\mathrm{pH}, \mathrm{pCO}_{2}$ and $\mathrm{pO}_{2}$ neither showed any signiflcant changes (table $6.4)$.

\begin{tabular}{c|ccc}
\hline ACETYLCHOLINE & \multicolumn{1}{|c}{$c$} & $60 \mathrm{MIN.}$ & $90 \mathrm{MIN}$. \\
\hline $\mathrm{PH}$ & $7.34 \pm 0.04$ & $7.33 \pm 0.06$ & $7.34 \pm 0.04$ \\
\hline $\mathrm{PCO}_{2}$ & $4.76 \pm 0.61$ & $4.64 \pm 0.82$ & $4.65 \pm 0.67$ \\
\hline $\mathrm{PD}_{2}$ & $3.56 \pm 0.53$ & $4.13 \pm 1.64$ & $3.69 \pm 0.67$ \\
\hline
\end{tabular}

TABLE 6.4

FETAL PH AND BLOOD GAS VALUES BEFORE, DURING AND AFTER THE ADMINISTRATION OF ACETYLCHOLINE TO THE EWE (MEAN $\pm S D$; $N=17$ ).

\subsubsection{Effect of continuous Infusion of noreplnephrine to the ewe on the matemal and fetal parameters}

The blood flow in the maternal vesseds substantially decreased Imnediately followlng the onset of the lnfuslon perlod as 1 s shown in figure 6.3, together with a fall in maternal heart rate. Blood Plow gradualily returned towards the prelnfusion level desplte the continued norepinephrine administration.

In five of the seven experiments internal 1llac artery blood flow was still decreased at the end of each sequentlal infusion perlod, but 
In two experdments blood flow hed returned to or above the control ralue.

The blood flow was further reduced wh th each following infusion pertod of fluteen minutes during which a higher dose of norepinephrine was administered. Agatn a slow retum of blood flow accurred during the rest of the infusion period.

The mean values of each interval are show in table 6.5. Only the blood flow in the Intemal 11 lac artery at the end of the first Infusion perlod was slgniflcantly reduced to $91.5 \%$ of the control value $(p<0.05)$.

\begin{tabular}{|c|c|c|c|c|c|c|c|}
\hline & & & $5^{\prime}$ & $30^{\prime}$ & $45^{\circ}$ & $\mathrm{O}^{\circ}$ & $90^{4}$ \\
\hline NOAEPUNEPHGINE & Controt & $4 / M N$ & $8 \mathrm{~J} / \mathrm{NAB}$ & $20 \mathrm{f} /$ 笛 & $40 \mathrm{f} / 1, \mathrm{IN}$ & \multicolumn{2}{|c|}{ RECOWEPY } \\
\hline $\begin{array}{l}\text { FHR }\{\mathrm{BP} 1\} \\
\mathrm{H}=17\end{array}$ & $160+45,0$ & $157+5,5$ & $162 \pm 9.7$ & .16444 .6 & $167 \pm 4.9$ & $166 \div 4,6$ & $170 \div 57$ \\
\hline 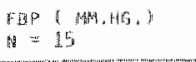 & $37,7 \pm 3,1$ & 37.323 .0 & $37.7 \pm 3.6$ & $42.2 \pm 3.1$ & 39.943 .6 & $41.1+3.6$ & 4I. U. \\
\hline 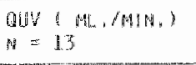 & $351+57$ & 354600 & $440 \pm 131$ & $459+112$ & $472+133$ & $461 \pm 131$ & $472+132$ \\
\hline 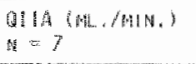 & 356446 & 326445 & $311+22$ & $202 \pm 3$ & $284+29$ & $336+38$ & $291+41$ \\
\hline 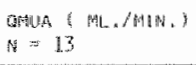 & $260+39$ & $249 \mathrm{LI}$ & $26 \mathrm{~L}+38$ & $244+36$ & $225+2 \pi$ & $285+35$ & $274+34$ \\
\hline
\end{tabular}

TMALE. B.

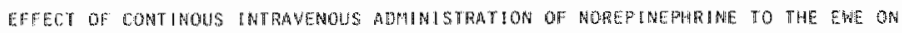

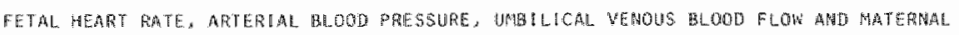

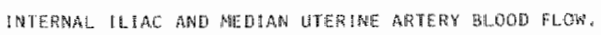

DATA ARE EXPRESSED AS MEAN + SERT, \& START DF THE INFUSYON $\%$

The blood flow lin the median uterine artery showed the same response pattern as the changes in the Internal 111 ac artery flow, although none of the values stgrificantly differed from control.

In elght experiments blood flow was still decreased at the end of each trifusion perlod, while in the remalning flve experiments blood flow was elther decreased or had already returned to or above the control value at the end of each infusion period. The mean values showed a small and Inslgniflcant decrease in flow at the end of each infusion perlod, with a return to control value in the recovery period. 
Fetal heart rate did not change during the infusion period but showed a small and slgnificant $(p<0.05)$ increase in the recovery period.

Fetal arterial blood pressure and umbilical venous blood flow ald not slgniflcantly change. No signiflcant changes occurred in fetal pH and blood gas values (table 6.6), which latter values showed a great standard deviation.

\begin{tabular}{|c|c|c|c|}
\hline NOREPI NEPHRINE & $c$ & $60 \mathrm{MIN}$. & $90 M 1 N$ \\
\hline $\mathrm{PH}$ & $7.32 \pm 0.06$ & $7.30 \pm 0.06$ & $7.29 \pm 0.05$ \\
\hline $\mathrm{PCO}_{2}$ & $5.11 \pm 0.64$ & $5.72 \pm 1.84$ & $6.33 \pm 2.31$ \\
\hline $\mathrm{PO}_{2}$ & $3.55 \pm 0.59$ & $4.26 \pm 2.41$ & $5.13 \pm 3.09$ \\
\hline
\end{tabular}

TABLE 6.6

FETAL PH AND BLOOD GAS VALUES BEFORE, DURING

AND AFTER THE ADMINISTRATION OF NOREPINEPHRINE

TO THE EWE ( MEANESD; $N=17$ ). 


\subsection{Discussion}

The observations on maternal pelvic blood flow in these experiments demonstrate not only that a great variation in uterine blood flow exists between different animals in the same period of gestation, but more inportant they show the relatively great short tem vartations occurring in uterine blood flow. The same phenomenon has been described by Clapp (1979). No signs of fetal distress in the fetal heart rate pattem were observed during the spontaneous blood flow decreases.

These varlations in blood flow Indicate on the one hand the great safety margin of the uterine blood flow rate for the fetus, but they 2Iso imply on the other hand a certatin restriction in regard to the interpretation of the effects of admintstered drugs on uterine blood flow.

Th1s is especially the case if not the immediate short term effects of vasoactive substances are the subject of study but if the influences on blood flow during a longer experimental period are concerned. Only few author's (Clapp 1979, Assal1 et al 1981) mention some of the problems assoclated with maternal pelvic blood flow measurements by means of. chronically implanted electromagnetic flow transducers. The fact that these problems are posstbly more often encountered than mentioned probably finds reflection in the design of many studies, In which only the immediate effects after bolus administrations or short lasting 1 nfusions are measured.

\subsubsection{Effect of continuous administration of fenoterol to the ewe on the maternal and fetal parameters}

Although the changes in blood flow were mall and except one value not significant, a distinct difference between the flow changes in the Internal 11tac artery and median uterine artery was observed. The Internal 1liac artery blood flow showed a relatively greater increase than the medlan uterine artery blood flow, while the former st1ll was Increased at the end of the post infusion period in contrast to the latter. ThIs finding suggests a greater sensitivity of the internal 11 lac artery than the median uterine artery or the vascular beds 
supplled by them to beta-adrenerglo receptor stimulation.

These changes in blood flow upon beta-adrenergic receptor stimulation are in agreement wth the results of Tabsh et al (1981) and Erkkola et a) (1981).

Erkkola et al (1981) found an increase in blood flow in the common internal 11 lac artery while the median uterine artery flow decreased or did not change upon intra-arterial stimulation of beta-adrenerglo receptors by isoprotereral administered directly into the aortic trifurcation. Tabsh et al (1981) also found a dfference in response. Common intemal 1liac artery blood flow remalned unchanged while the blood flow in the median uterine artery progessively decreased during Intravenous Infusion of the beta adrenergic agonist isoxsuprine, which dmug has also alpha-adrenergic properties.

Tabsh et al (1981) suggested that the different functions of the tissues supplied by respectively the median uterine artery and the dorsal uterine artery, which is one of the other great branches of the Internal $111 \mathrm{ac}$ artery, required different neurohumeral mechanisms for hemodynamic adjustments. The middle uterlne artery supplies the fundus and corpus uterl, the contractlle part of the uterus, whlle the dorsal uterine artery supplies the lower uterine segment, the cervix and the vagina, the more passive part of the uterus, and furthemore part of the bladder. The remalnder of the internal illac artery flow is destined for extra-genital struatures.

A difference in adrenergic receptor sensitivity of the vascular bed of the median and dorsal uterine artery might explain the difference in flow changes between dorsal uterine artery (as they are reflected in the flow of the common internal illac artery) and median uterlne artery.

Brennan et al (1977) measured blood flow in the maln uterlne artery, a terminal branch of the intemal lilac artery, glving rise to the median and dorsal uterine arteries, during continuous intravenous infusion of fenoterol to the ewe. The abserved small Increases in flow are in agreement with the concept of Tabsh et al (1981).

The data from the present study also f1t into the concept that the vascular bed of the Internal 111ac artery can be divided in that of the median uterine artery with a relatively small beta-adrenergic 
sengltivity, and in that of the dorsal uterine artery and other nongenteal stmutures whlch react with a blood flow increase upon beta-adrenerglo recepror stimulation.

Fetal heart rate, arterial blood pressure and umbllical venous blood wow were not affected by the matemal fenoterol infusion, except for a very mall but slgnlflicant decrease in heart rate at the end of the Infuston period. Thls finding is sonewhat curious, because if an effect had to be present, then a fetal tachycardia would be expected. Ehrenkranz et al (1977a) and chez et al (1978) did not find any slgniflcant change in fetal heart rate, blood pressure or umbilical venous blood flow.

Fetal pl and $\mathrm{pO}_{2}$ did not change, whereas fetal $\mathrm{pCO}_{2}$ was signiflcantly decreased at the end of the infusion period and the recovery perlod. A sunficant decrease in fetal $\mathrm{pCO}_{2}$ together with an increase in fetal WH was fourd by Bremnan et al (1977) during infusion of ritodrine to the ewe, whlle no changes were observed durlng fenoterol administration. An explanation for this decrease in fetal pCo, cowld be a decrease in maternal $\mathrm{pCO}_{2}$ during hypervent1lation, assoclated wth beta-sympathicomimetic drus infusion.

It Indicates that fenoterol infusion to the mother at least did not adversely affect fetal acld-base balance.

\subsubsection{Effect of continuous adninistration of acetylcholine to the ewe on the matemal and fetal parameters}

Acetyloholine $1 \mathrm{~s}$ known as a peripheral vasodllator. No Indlcation was found from the present data that cholinergic stimulation via Intravenously administered acetylcholine has an effect on the blood fllow in the Interna]. 111ac artery. The same can be said about the medlian uterine artery blood flow since only one value showed a weak slgulflcant Increase over the control level, whereas the flow values from the sequentlal infusions with higher doses of acetylcholine thereafter did not change. "The meaning of this single signiflcant Increase is therefore questlonable.

The absence of any increase in blood flow In the internal $111 a c$ artery is In agreement with the results from Assali et al (1981) who also 
found no change in blood flow in the common internal illac artery upon intravenous acetylcholine infusion. Bolus injections directly into the aortic trifurcation (2 to 64 gamma) on the other hand caused a snall increase in the blood flow in the comon internal 11 lac artery (Erkkola et al 1981, Assall et al 1981), but no changes in the median uterine artery flow (Erkkola et al 1981).

Erkkola et al (1981) suggested the exlstence of" cholinerglo receptors in the vascular bed of the common Internal 11 lac artery and the absence of a strong cholinergic control of the median uterine artery. The conclusions of Grelss et al (1967c) that acetylcholine caused vasodilatation in the uterine vascular bed were questioned by them on the basis of the magnltude of the reponted uterlne blood flow changes and on the fact that central circulatory changes could have attributed to the flow increases.

Important evidence for the lack of cholinergic control of uterine blood. f"low is the absence of cholinergic vasomotor nerves to the parametrial. vessels in the sheep (Bell 1971) and the absence of any change in uterine blood flow upon alrect stimulation of the pelvic parasympathetic nerves (Greiss $1967 \mathrm{~b}$ ).

W1th regard to the fetal parameter's, the absence of any changes indicates that acetylcholine was not or only minlinally transferred via the placenta to the fetus.

No Indications for any cholinerglc influence on the blood flow in the internal iliac or median uterine artery were obtalned from the results of these experiments.

\subsubsection{Effect of continuous deministration of norepinephrine to the ewe on the maternal and fetal parameters}

The magnitude of the decreases in internal 11 lac and medifun uterine artery blood flow were except durling one interval not signtficant and were much smaller than those reported by others "Greiss 1963, Barton etw al 1974, Chez et al 1978, Tabsh et al 1981, Assell et al 1981).

In each of these studies the maximum response upor norepinephrine adminlstration elther in a bolus injection intraarterially or Intravenously (Grelss 1963, Cher et al 1978, Assal1 et al 1981) or in a 
continuous systemic intrawenous or local intraarterially infusion (Barton et al 1974, Rosenfeld et al 1976, Tabsh et al 1981) were assessed.

As can be seen in fligure 6.3 the maxum response occurred in the first few mirutes after the start of the infusion and the blood flow decrease at that moment is impressive, but is not sustained throughout the total Infusion period. In fact after an initial substantial decrease blood flow had already retumed towards the control level at the end of the 15 minute Infusion pertod in several experiments. These observations not only explain the differences in magnitude of the flow decreases between the pesults of others and the present data but also lead to the tentative conclusion that systemic infusion of norepinephrine leads to a substantlal decrease in intemal $111 \mathrm{ac}$ and median uterine antery blood flow which gradually but certainly not completely abates with time desplte continued drug administration.

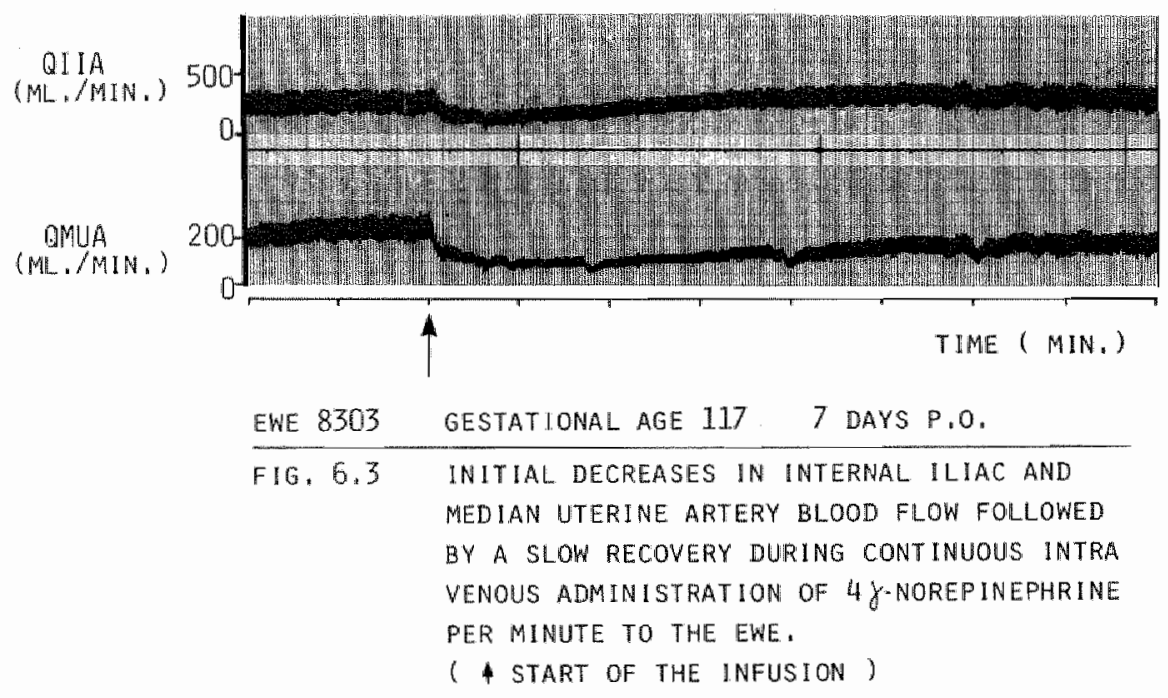

Thls adaption in time might be caused by compensatory autonomic reflexes and/or local factors involving prostaglandin production. Fetal heart rate and arterlal blood pressure did not change slgniflcantly during Infusion in contrast to the results obtained by 
Chez et al (1978), who found a slight Increase in blood pressure and a small decrease in fetal heart rate.

Fetal arterial blood pressure did show an incremental trend in the present data. Umbilical venous blood flow showed a great variation without any significant change.

The small but signiflcant increase in fetal heart rate and the small decrease in arterial pH during the recovery period suggest a certain adverse effect of the diminished uterine blood flow on the fetal condition.

\subsection{Final remarks}

The recordings of the Internal illac and median uterine artery blood flow learnt that matemal pelvic vascular blood flow showed great fluctuations in time not only induced by several stimuli but also "spontaneously"! occurring.

Furthermore considerable differences in absolute flow between the animals exlsted and the degree or direction of flow changes upon drug infusions in various animals was not always identical.

Although certain trends in effect could be observed, most of the changes in maternal blood flow were not statistically different from control.

The results are compatible with blunting of the effects of autonomic vasoactive drugs on the uteroplacental and pelvic vascular beds during pregnancy. This latter phenomenon is potentialiy protective for the fetus.

Possibly other mechantsms than the influences of the autonomic nervous system are more Important in the regulation of uteroplacental blood flow. 
CHAPIHR VII

FETAL BREATHING MOVEMENTS AND UMBILICAL VENOUS BLOOD FLOW

\subsection{Introduction}

Fetal breathing movements refer to fetal chest wall and dlaphragmatic movements which mimic in utero the respiratory movements of postnatal life. In contrast to the situation after birth, gaseows exchange and alveolar expansion do not occur during intrauterine life, and in this respect the name fetal breathing movements is somewhat misleading. Fetal breathing movements exist in fetuses of all mammals studied thus far, including the human. An extenslve review on fetal breathing movements is given by Wilds (1978) and Lewis and Boylan (1979). Acute studies of fetal breathing movements in animals have a much longer history than observations of human fetal breathing movements. Béclard (1815) described in his often cited studies rhythmic movements of the fetal thorax and abdomen in dogs and kittens after opening of the uterine wall but with intact fetal membranes. The same movements were already observed by Winslow in 1781 (cited by Wilds 1978) after exposure of the uterus in dogs and cats.

Rhythmic breathing movements of the Intrauterine human fetus were first described by Ahlfeld, a Genman gynecologist in 1888. He observed perlodic and rhythmic intrauterine fetal movements in the periumblilical area of the intact abdomen of pregnant women, which he later ascribed to fetal respiratory movements. His observations were regarded by his contemporaries with scepticlsm, and the nowadays general accepted vlew that intrauterine breathing movements are necessary for a proper respiratory adaption after birth was denied. Ahlfeld himself however" was convinced of this necessity: "Ich behaupte aber mit Bestimmthelt: 
Ich halte es fur ganz umoglich, dass eln Organ in Thatigkelt tritt, wen es geboren 1st, welches vorher noch nicht thatig gewesen ist. Ein Muskel kann rur 1eber, wem er in Thatigkelt 1st; nur wen er sich zusammenzisht, kann er sich entwickeln" (Anlfeld 1888).

It is now cledr" from animal studies that fetal breathing movements are not only mecessary for a proper development of intercostal and daphragnatic musculature but also establish the transport and spread of surfactant from the alveolar type II-cells over the total Iung area. Surfactant 1 s essential for the prevention of postnatal alveolar collapse. Clinical observations of severe resplratory distress syndrome and lung hypoplasla in newboms with abnomallties of the respiratory muscles (as, for example, in arthrogryposis multiplex congenita) underline this vlew. The occurrence of fetal breathing movements under experimental conditions in animals was until 1970 regarded as a consequence of fetal tactile stimulation or asphyxla during the acute experiment.

In 1970 however both Dawes et al in Oxford and Merlet et al in Par1s reported the existence of spontaneous fetal breathing movements of the fetus in utero. Two breathing patterns were recognized in both intrauterine and exteriorlzed lamb fetuses. The first was a predominant, rapid, shallow, usually iregular breathing activity up to 50 percent of the time, characterized by varying rates of 1 to $4 \mathrm{Her}$ with interspersed eplsodes of apnea. The second pattem consisted of sporadic, deep Insplratory efforts at a rate of two to four per minute during about 5 percent of the time. The existence of breathing movements In the sheep fetus was conflmed by the findings of the two aforementioned groups and whese breathing movements were seen to be a spontaneous physlolog $1 \mathrm{c}$ phenomenon.

Since 1970 numerous Lrvestigat Lons on fetal breathing movements and the factors which affect them have been published.

It 1 s beyond the scope of this section to rewlew the 11 terature on this topic but a short and certainly not complete summary of the factors that affect fetal breathing rovements is given in table 7.1 .

The relations between breathing movements and brain activity have recently been studied by van der wildt (1982). 


\begin{tabular}{ll}
\multicolumn{1}{c}{ DECREASE } & \multicolumn{1}{c}{ INCREASE } \\
\hline HYPOGLYCEMIA & HYPERGLYCEMIA \\
HYPOXIA & HYPERCAPNIA \\
MATERNAL ACTIVITY & CAFFEINE \\
UTERINE ACTIV! & THEOPHYLLINE \\
MATERIAL ABDOMINAL PALPAT:ON & DOXAPRAM \\
FETAL TACTILE STIMULATION & EPINEPHRINE \\
FETAL TEMPERATURE CHANGE & TETRABUTALINE \\
SUPINE HYPOTENSION & INDOMETHACIN \\
CIGARETTE SMOKING & MECLOFENAMATE \\
ALCOHOL & \\
BARBITURATES & \\
PETHIDINE & \\
DIAZEPAM & \\
PROSTAGLANDINE E 2 & \\
PARTURITION & \\
\hline
\end{tabular}

TABLE 7,1 FACTORS WHICH AFFECT FETAL BREATHING MOVEMENTS (MODIFIED FROM HILL, 1983),

\subsection{Fetal breathing and chest wall movements}

The primordium of the respiratory system first appears during the third to fourth embryonic week as an outgrowth from the ventral wail of the foregut and by the tenth week of life, all of the characteristic features of the respiratory tract are present. Fetal breathing movements have been detected from the eleventh week by an A-scan ultrasound system (Boddy and Roblnson 1971). Fetal breathing movements increase in rate, depth and incldence and become more organized as pregnaney advances and repiratory neuroregulatory control matures. Breathing movements in the fetal lamb are associated with contractions of the diaphragmatic and lower intercostal muscles (Dawes et al 1972, Maloney et al 1975, Harding et al 1977, Chapman et al 1980). Dawes et al (1972) showed that rapld irregular breathing movements whlch were obserwed after delivery of fetal. lambs with intact umblical circulation into a warin saline bath were characterized by inward 
movements of the thoracic wall and outward movements of the abdomen. Marsal (1978) found the same phenomena in the human, as did Poore and Walker (1980) In fetal lambs. Poore and Walker Implanted pairs of Ultrasonic transducers on opposite sides of the thorax of fetal lambs provided with a tracheal catheter and they recorded changes in chest wall dimension associated wth tracheal pressure changes.

The fetal chest wall responds to the pull of the diaphragm by an inward movement, which is maximal at the level of the xiphistermum (Marsal 1978). The relation between diaphragmatic activity and negative deflections in the intratracheal pressure recordings was demonstrated by Maloney et al (1975).

Fetal breathing movements are paradoxical (Bots 1977): contraction of the diaphragm and other respiratory muscles in the adult leads to an enlargement of the thoracic cavity which allows lung expansion during Insplration. In the fetus however, the attempts to enlarge the fetal thoracic cavity during inspiratory movements, are counteracted by the large alrway resistance of the fluid-filled lungs and possibly by the high tonus of the laryngeal muscles (Maloney et al 1975). The inspiratory phase is therefore prolonged and exceeds the expiratory phase by 3 to 1 with a small tidal wo ume and a tracheal fluld flow of approximately $0.5 \mathrm{ml}$, but during maximum inspiratory gasping efforts in asphyxial states, however, the tidal liquid flow may exceed $10 \mathrm{ml}$.

Although the antero-posterion diameter of the chest diminishes during an Inspiratory movement with the dlaphragm moving dowmwards during contractions, the net result is a small enlargement of the thoracic cavity as is obvious from the pressure fall in the thorax during insplration.

The concomitant outwat movement of the abdominal wall may be a passive movement caused by the reduction in size of the abdominal cavity caused by the downward movement of the diaphragm.

It is likely that the pressure in the abdominal cavity increases during insplration with the outward movement of the abdominal wall as a corresponding result. 


\subsection{Cardiovascular effects of fetal breathing movements}

The cardiovascular effects of fetal breathing movements in long term experiments in lambs have been described in several studies. Fouron et al (1975) reported episodes of fetal tachycardia of ten followed by elevations of systolic and diastolic blood pressure to $50 \%$ above base line levels, associated with breathing episodes. The hypertensive eplsodes often coincided with transient increases in the rate and depth of breathing movements. A cardiac arrhythmia synchronous with respiratory activity was also seen.

Dalton et al (1977) observed a consistent increase in heart rate varlability during breathing episodes in chronic lamb studies, and the degree of heart rate variability was related to the amplitude and the frequency of the tracheal pressure changes.

Rurak and Gruber (1983) found in chronically Instrumented fetal lambs transient increases and decreases in blood pressure during fetal breathing movements and no significant changes were found compared to the blood pressure before or after the breathing episode.

Martin et al (1974) also observed increased heart rate variablilty and a respiratory arrhythmia during fetal breathing activity 1 . chronic Rhesus monkey experiments.

Van der Wildt (1982) quantitated the beat to beat heart rate varlability by means of the interval difference index and he found a strong relation with the presence or absence of rapid irregular fetal breathing movements, whlch occur only during low voltage electrocortical states.

It was suggested by Fouron et a? (1975) that the cardiovascular effects of fetal breathing movements resulted from increased secretion of catecholamines by the fetus durlng breathing movements. Undoubtedly more factors are involved, as e.g. the influence of fetal breathing movements upon umbilical venous and vena caval blood flow and right atrial filling patterns.

\subsection{Umblilical blood flow and fetal breathing movements}

Rurak and Gruber (1983) found an increase in unbilical flow of $52 \pm 12$ 
milmin/lg durlng breathing activity in 9 of 16 samples in their experiments in chronically instrumented fetal lambs while in the other 7 it decreased by $23 \pm 9 \mathrm{ml} / \mathrm{min} / \mathrm{kg}$. The unbliscal blood flow was measured wing the steady-state diffusion technique with antipyrine as the test substance. They ascribed this increase to the general tendency for heart rate and arterlal pressure to increase. A strong passitive correlation between heart rate and unbllical blood rlow was reported by Rudolph (1976).

Dawes et al (1972) obsemed an Lncreased descending aortlo blood flow In assodation with tachycardia and hypertension during breathing eplsodes which might suggest that mbilical blood flow also would increase. An increase in left ventricular output however does not automatically imply an increase in umbllical blood flow. During vigorous breathing movements, Rurak ond Grubem abserved a fall in unbllical blood flow, but no concomitant data on fetal heart rate during those eplsodes were avallable. They suggested that the large intrapleural pressure changes $(5-30 \mathrm{~mm} \mathrm{Hg})$ assoclated with vigorous breathing could cause phasic reductions in ventricular output with consequent decreases in umbllical blood flow.

The Instantameous effect of Inspiratory movements upon umblilcal venous blood flow was measured by Chlba et al (1981) in the human fetus, using a pulse-Doppler flow transducer in combination with real-time B-scan echography. They found that fetal breathing movements changed the flow velocity in the umblilcal veln. When the abdominal wall was moving Inwards, whlch movement they erroneously considered "Insplration", an Increase in umbllical venous flow was found, whlle during "explration" a decrease in flow occurred. However thelr defintion of insplration and explration is confusing and 1t seems that they did not take into account the paradoxical breathing pattern of the fetus.

Gough and Poore (1977) used an ultrasound transducer in the tip of a catheter in chronlc lamb studies to recond fluctuations in venous retum in the inferlor vena cava during fetal breathing movements. Doppler shift fluctuations in the with fetal breathing movements ware present in the inferior vena cava at the level of the diaphragm, especlally at the juncture of the hepatic and diaphragnatic velns with 
the vena cava. These slgnals may be generated from flow changes in the umbilical vessels colncident with breathing movements (Goodman and Mantell 1978).

In a study on the basic low patterns in the superlor and 1nferion wenae cavae, Reuss et al (1983) showed struking changes in flow pattems occurring with fetal breathing movements. A decrease in tracheal or intrapleural pressure during an insplratory movenent caused an increase of venous forward flow. Thls increase in flow was in general proportional to the decrease in pressure. When large negative pressures were generated by regular deep breathing movements, marked venous pulsations occurred sometimes doubling or tripling the amplitude of the verous flow patterns. Fetal breathing movements also affect the instantaneous flow pattem in the comon umbllical veln (Hasart and de Haan 1982, 1983a).

\subsection{Atm of the study}

It is know that fetal breathing movenents influence the occurrence of the short tem irregularity in the fetal heart rate pattem. The short term irregularity is regarded in human obstetrics as a parameter for the estimation of fetal well belng.

Bots et al (1978), Dawes et al (1981), Campogrande et al (1982) and N1 jhuis et al (1982) showed that fetal heart rate decreases together with an increase in the short term variabil1ty during fetal breathing movements. This increased short tem varlabllity might in part be caused by changes in the venous blood flow retuming to the fetal heart during breathing movements.

This part of the study was undertaken to Irrvestigate the effects of spontaneously occurring fetal breathing movements upon instantaneous umbll1cal venous blood flow. Furthemore the effects of fetal gasplng: during fetal asphyxia, as accomplished by translent occlusion of the maternal common internal $111 \mathrm{ac}$ artery or the fetal umblilcal cord, upon umbillcal venous flow were studled. 


\subsection{Matertals and methods}

The fetal breathing movements were recorad by means of an Intratracheal Fluld-flled catheter, connected with a pressure transucer (see chapter 2). Since the fetal thorax contains no gas, the pressure changes resulting rrom breathing movements are transmitted relatively undamped to the other intrathoracle structures and are superimposed on clrculatory and oesophageal pressure changes. Annilotic pressure changes are in the sane way superimposed on the intrathoracle pressures and must be subtracted or otherwlse accounted for in relating pressure changes to fetal breathing movements.

Perlods with fetal respiratory movements were observed in six fetal larbos provided with a intratracheal catheter. Gestational age ranged from 106 to 143 days. Fetal breathing movements were identifled visually comparting the tracheal and amiotic pressure registrations on the recording paper.

Instantaneous umblilcal venous blood flow was studied during rapld Irregular breathing movements, unusually vigorous breathing movements, gasping and expiratory efforts.

\subsection{Results}

\subsubsection{Rapid 1rregular breathing and instantaneous umbllical venous blood flow}

During rapid irwegular breathing movements with an amplitude of 3 to 12 mm $\mathrm{Hg}$ and a frequency of $1 \mathrm{~Hz}$ and higher, Instantaneous umb11.cal venous blood flow showed a marked increase in amplitude (fig. 7.1), which was caused by the occurrence of a flowpattern with undulations in line with the frequency of the breathing movements (fig. T.2).

The undulatory pulsations in the tracheal pressure recording and the umblilcal venous flow recordlng were slightly out of phase (flg.7.2). The time delay caused by propagation of the pulse wave of the tracheal pressure change to the pressure transducer must be accounted for when comparing the pressure changes with the electromagnetically recorded 


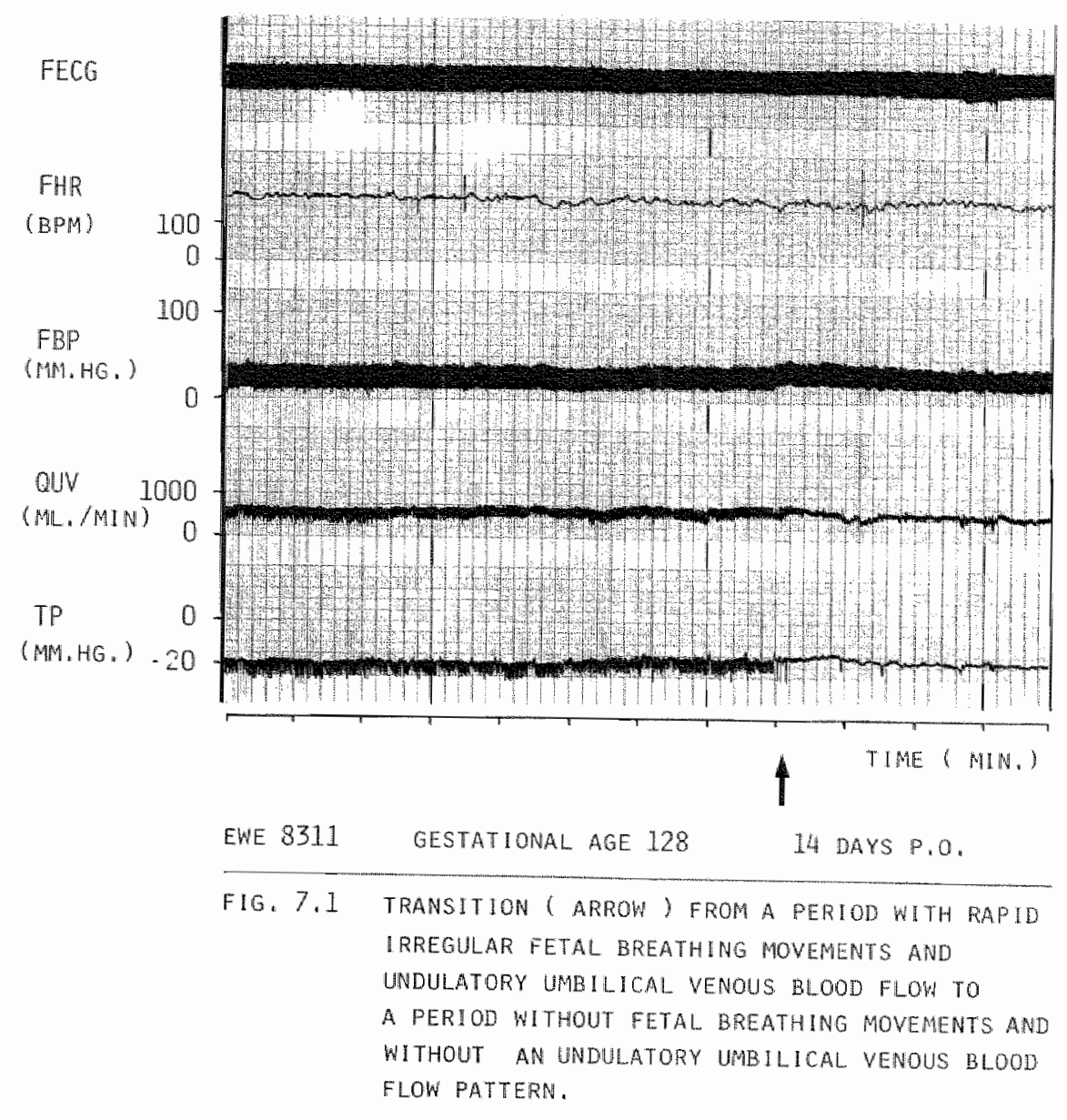

flow changes. Two kinds of variables add to the delay time in pulse wave propagation. Flrst there is a technical factor namely the delay in pulse wave propagation caused oy the intratracheal inserted polyvinyl catheter, the connecting polyethyleen catheter and the stopcocks. The total delay in pulse wave propagation amounts $40 \mathrm{msec}$ for the catheter and connecting system used in this study (Evers 1978). The second important physiological factor lis the probably high compliance of the fluid filled tracheal system, which has an open connection with 


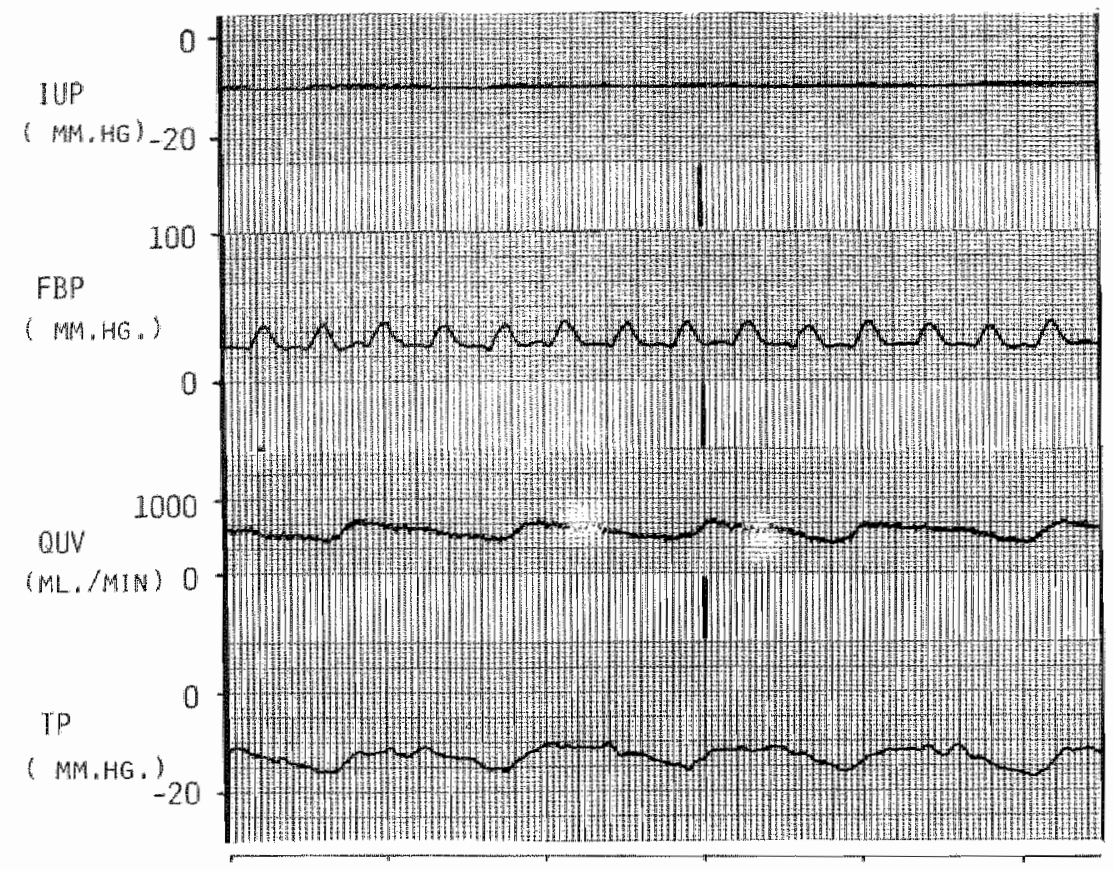

TIME ( SECONDS )

EWE 8311 GESTATIONAL AGE $128 \quad 14$ DAYS P.O.

FIG. 7.2 TIME RELATIONSHIP BETWEEN FETAL BREATHING MOVEMENTS AND THE THEREBY CAUSED UNDULATORY CHANGES IN UMBLLICAL VENOUS BLOOD FLOW.

the oral cavity. A high compliance decreases the pulse wave velocity, adding a second time delay to the propergation of the pressure wave. The magnitude of this second time delay ws unknown, but nay amount up to 20 msec according to the total time delay found In most cases. The time delay caused by the electronagnetic clrcult of the flow transducer system is negliglble. The total time delay between the onset of the umbl1Lal flow decrease and the onset of insplration was in the range of 40-60 msec in most instances, and did not exceed 100 msec. The relation between tracheal pressure and umbll1cal venous flow recordings 


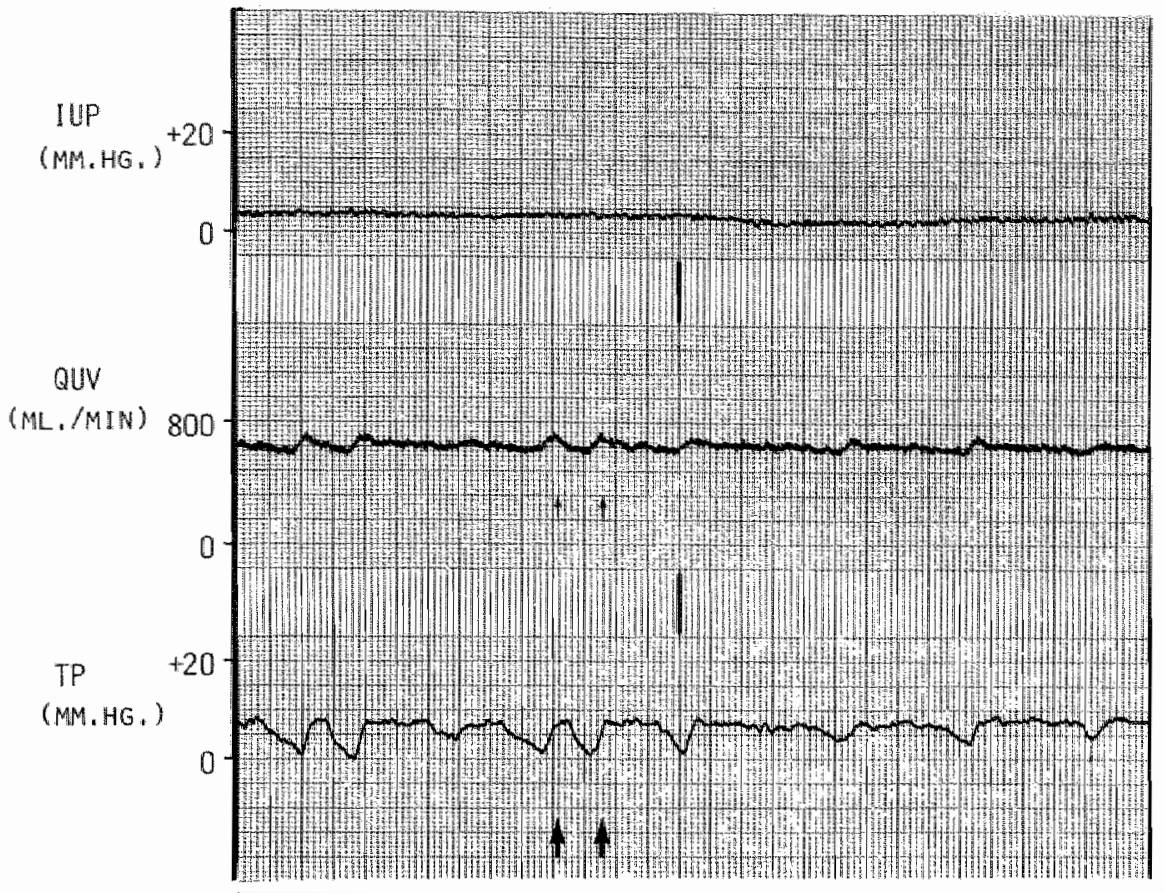

TIME ( SEC.)

EME 83\11 GESTATIONAL AGE 120 G DAYS P.O.

FIG 7.3 OVERSHOOT OF UMBILICAL VENOUIS BLOOD FLOW

AFTER A FETAL INSPIRATORY MOVEMENT (ARROWS)

can then after correction for the time interval be described as follows.

During inspiration characterized by a drop in tracheal pressure, umbillcal venous blood flow decreases. Umbllical venous blood flow returns to its baseline with the explratory part of the breathing cycle (fig. 7.2). Sometimes a small overshoot in the umbllical blood flow was observed at the end of the explration (fig. 7.3). The undulatory pulsations varied with the magnitude of the breathing amplitude. Greater pulsations were observed with deeper tracheal pressure drops. 
Incldentally periods wh urusual vigorous breathing movements were present wh large changes in the willcal venous flow pattem.

Although heart varlabllty was not quantifled in this study, the Impression of an increased heart rate varlabli1ty during periods with fetal breathing movenents existed on visual inspection of the analog recordings. This is in agreement with the findings by others (Martin et al 1974, Dalton et a.1 1977, van der w1ldt 1982).

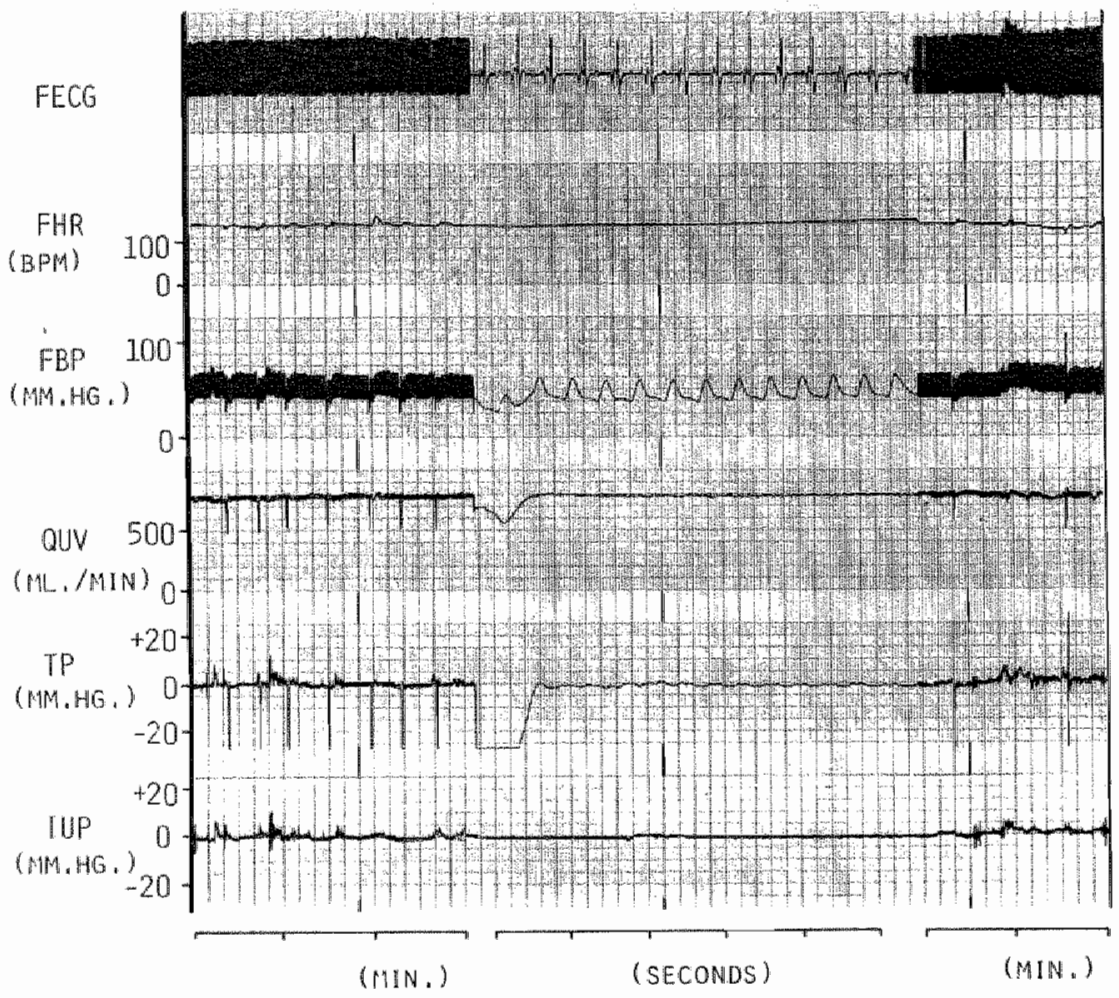

EHE 8304 GESTATIONAL AGE $140 \quad 12$ DAYS P.0.

F16.7.4 EFFECT OF ISOLATED FETAL HICCUPS ON HEART
RATE, ARTERIAL BLOOD PRESSURE AND UMBILICAL
BLOOD FLOW.


7.7.2 Fetal hiccups and instantaneous umbllical venous blood flow

Fetal hiccups, characterized by single brief and relatively deep Inspiratory efforts recurr 1 ng irregularly at a much slower rate (1-4 /min) than rapid breathing movements, resulted in a much greater decrease in instantaneous umbilical venous blood flow than occurred with rapid irregular breathing movements ( $\mathrm{flg}$. 7.4). Arterial blood pressure decreased during hlccups followed by a small overshoot. The same decrease and increase was found in the fetal heart rate (fig 7.4). These deep inspiratory efforts are probably hiccups but mitght also be isolated deep breaths, or resplratory movements assoclated with bringing up material from the rumen.

\subsubsection{Explratory efforts and instantaneous umblilcal venous blood flow}

Inspection of the tracheal pressure recordings also showed incidentally brief rises in tracheal pressure during a perlod without other breathing movements. No inspiratory component was associated with these expiratory efforts. IJmbllical venous blood flow decreased during such an expiratory effort. No changes in armlotic fluid pressure were seen at those monents. Fetal heart rate showed a slight decrease during such an explratory effort (fig. 7.7).

7.7.4 Fetal 1ntraabdominal and 1ntratracheal pressure during fetal resplratory movements

The intraabdominal pressure was measured in two fetuses, also provided with an intratracheal pressure catheter.

The intra abdominal pressure also changed with fetal breathing movements but in the opposite direction as tracheal pressure: during a fall in tracheal pressure with insplration there was a rise in the Intra abdominal pressure, while Intra abdominal pressure decreased again with the rise in intracheal pressure during expiration ( $f$ ig. 7.5 and 7.6$)$. 


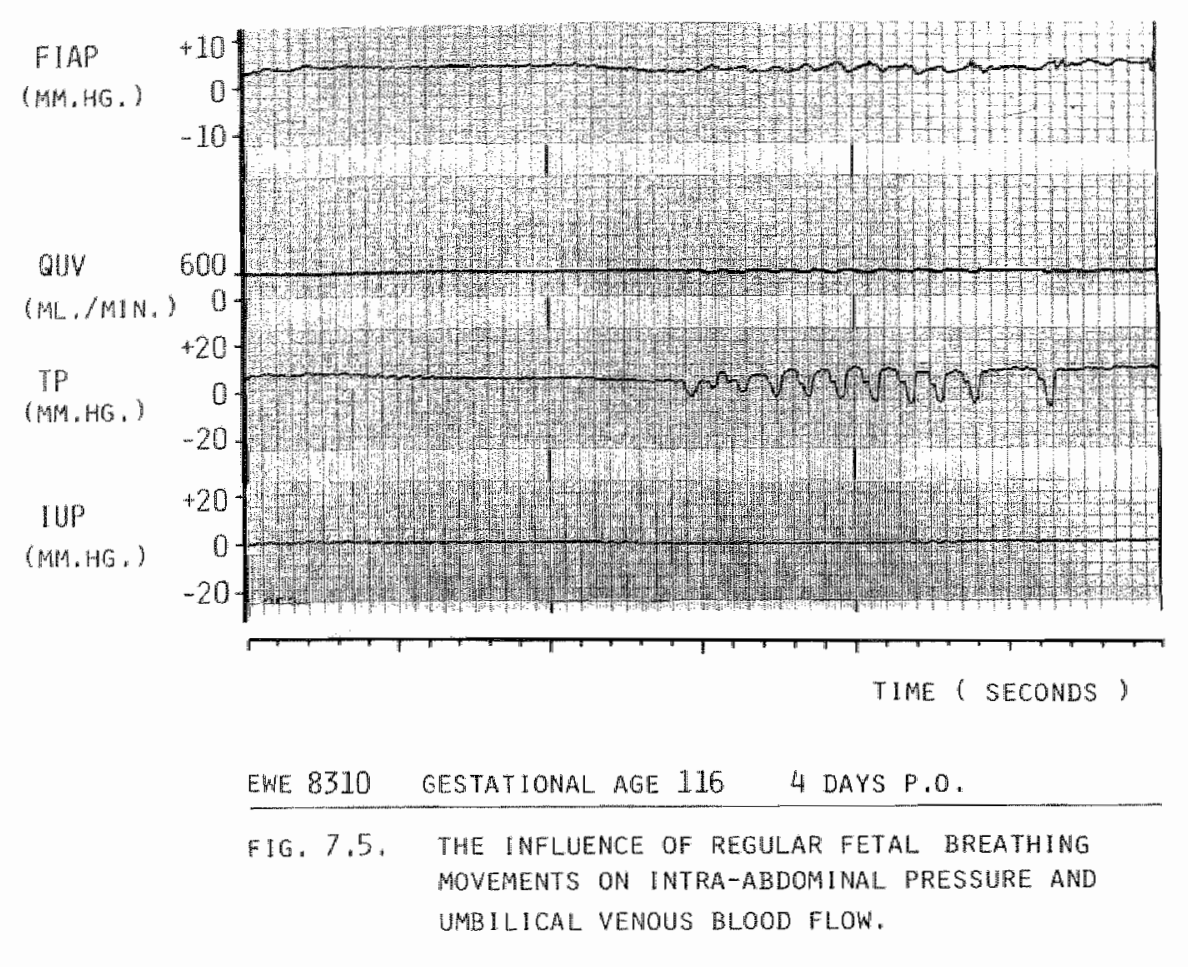

Deep tracheal pressure drops during fetal hiccups were accompanied by marked increases in intra abdominal pressure.

Fetal expiratory efforts without any inspiratory component as described In 7.7.3 caused a change in tracheal and intra abdominal pressure in the ame direction: both pressures increased whlle umblilical venous blocd flow decreased ( $\mathrm{flg}$. 7.7).

\subsubsection{Fetal gasping and instantaneous umbillcal venous blood flow with umbilical cord occlusions}

Temporary occlusion of the total umbilical cord may lead to fetal asphyxia and fetal gasplng can occur under such circumstances (Dawes et al 1972). These gasping efforts may have a much greater amplitude than those "spontaneously" occurring ( fig. 7.8). 


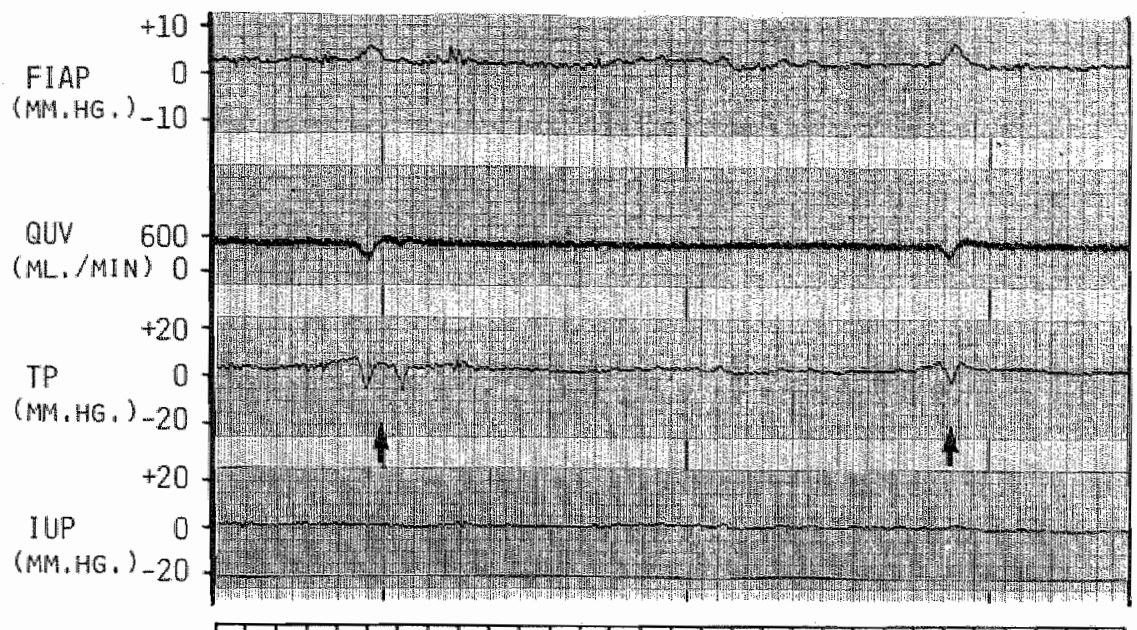

TIME (SECONDS)

EME 8310 GESTATIONAL AGE $116 \quad 4$ DAYS P.0.

FIG.7.6. EFFECT OF ISOLATED INSPIRATORY MOVEMENTS ( ARROWS) ON INTRAABDOMINAL PRESSURE AND UMBILICAL VENOUS BLOOD FLOW.

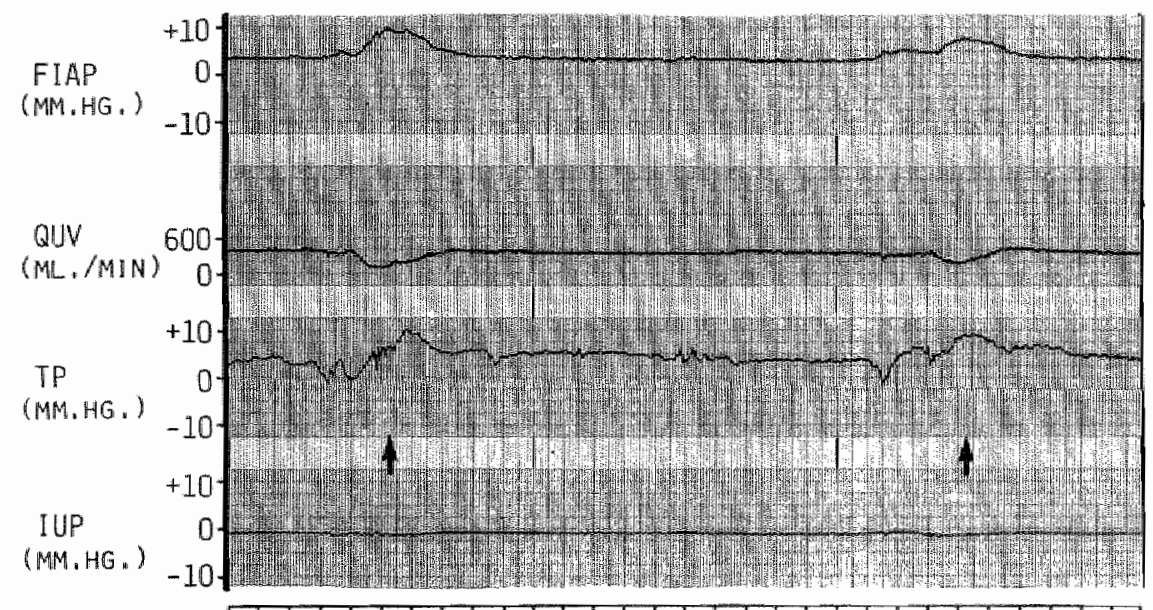

TIME (SECONDS)

EWE 8310 GESTATIOMAL AGE 115 IISAYS P.O.

FIG.7.7 EFFECTS OF FETAL EXPIRATORY EFFORTS, GRUNTING OR VALSAVA LIKE MANOEUVERS (ARROWS), ON INTRAABDOMINAL PRESSURE AND UMB ILICAL VENOUS BLOOD FLOW: 


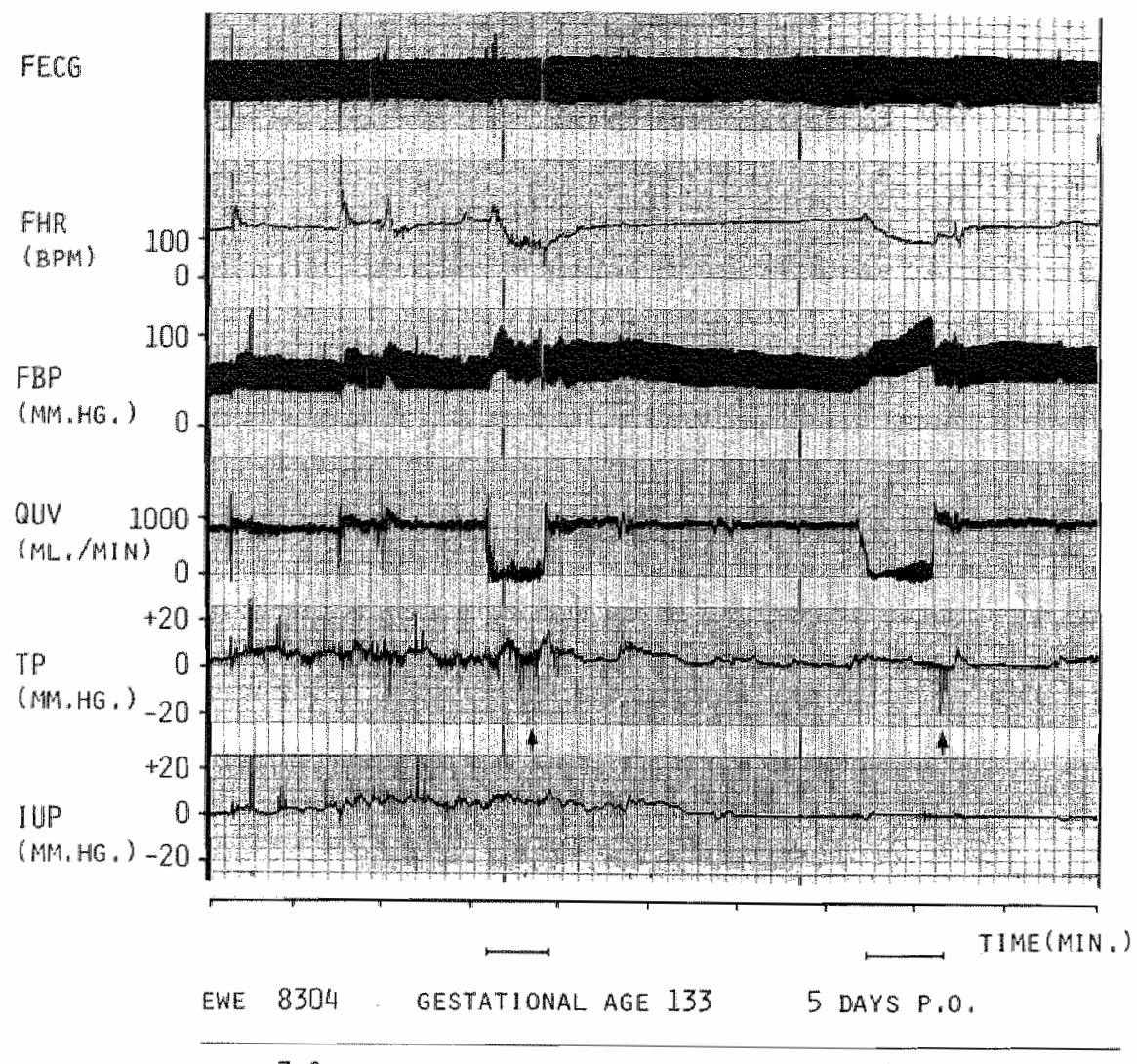

FIG.7.8 FETAL GASPING MOVEMENTS (ARROW) DURING AND AFTER TOTAL UMBILICAL CORD OCCLUSION $(-\infty)$

The umblilcal venous flow changes, occurring with the fetal gasping movements, were then superposed on the already present biphasic venous pulsations, which were caused by backward propagation of the increased pulsatility in the vena cava inferior to the common umbilical vein (see chapter 4). Fetal gasping w1th umbilical cord occlusion occurred towards the end or inmedlately following the accluston. 
These gasping movements had an overriding effect on the already present biphasic venous pulsations.

Also in cases with biphasic venous pulsations caused by other events than umblifal cord occlusion as e.g. acetylchollne administration to the fetus or occlusion of the matemal comon intemal 11 iac artery, fetal gasping efforts were sometimes observed. The influence of fetal gasping on the pulsatory umbilical venous blood flow had the same effect then as during umbilical cord acclusion.

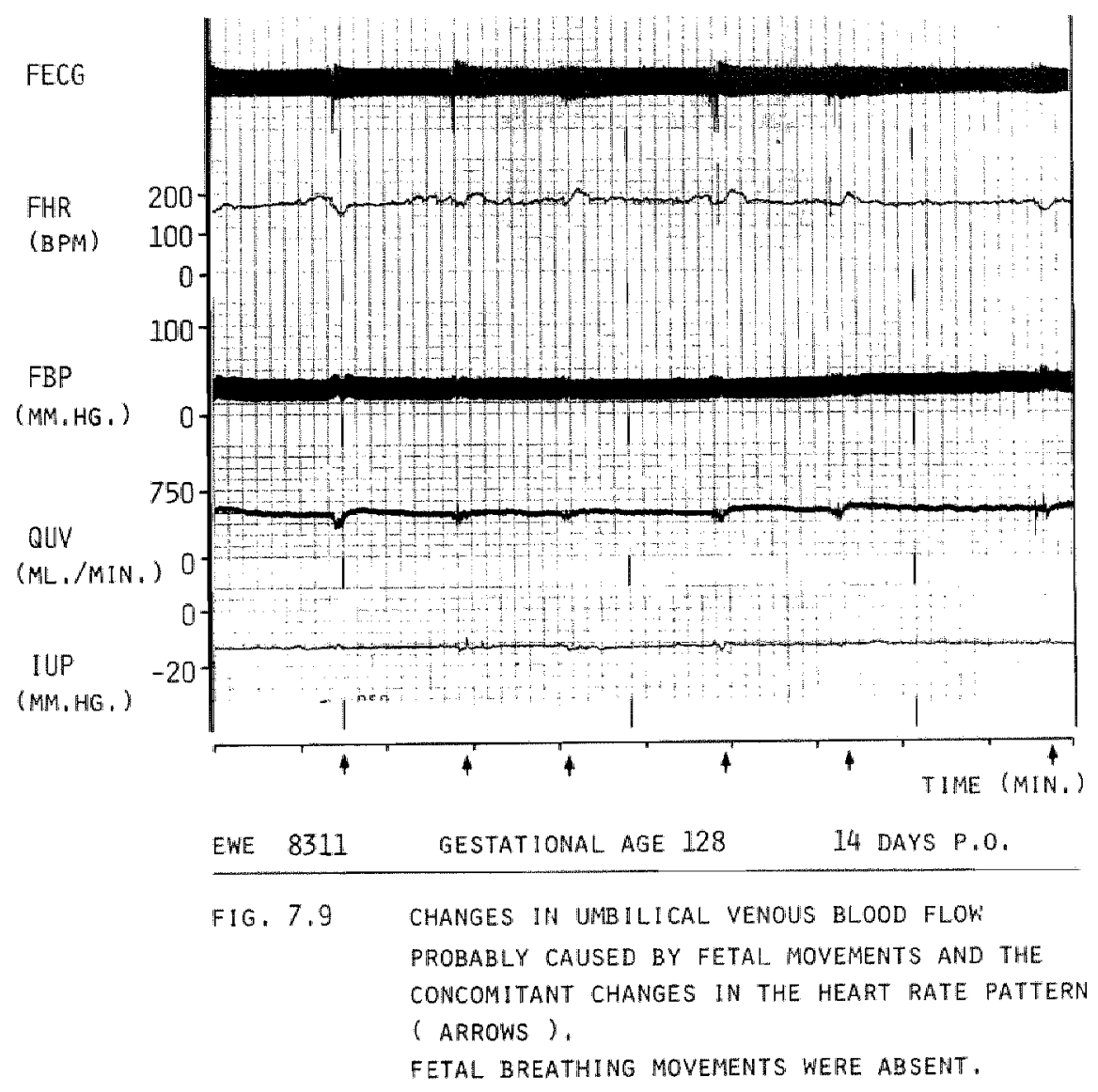




\subsection{D1scussion}

These data show that fetal breathing movements inf'luence the blood flow pattem in the comnon umbilical vein.

The decrease in umb1lical venous flow during a decrease in tracheal pressure can be explained by the concomitant increase in intraabdominal pressure, caused by the downward movement of the diaphragm during inspiration. This increase in intraabdominal pressure partiy compresses the intraabdominal common umblilical vein with a decrease in flow as result.

Thls flow change is different from the flow alterations occurring in the thoracic cavity. The fall in the intrathoracic pressure with inspiration acts as a certain suction force on the vena cava flow: a decrease in tracheal pressure causes an increase in forward flow in both the superior and inferior vena cava, which is proportional to the decrease in Intratracheal pressure (Reuss et al 1983).

Phasic descending aortic flow on the other hand shows brief decreases in flow conmensurate to the brief falls in arterial pressure occurring with each decrease in intrathoracic pressure (Dawes et al 1972). The phasic aortic flow irmediately after the tracheal pressure fall shows a small increment, as can be seen in the figures from the article by Dawes et al (1972). This increment may not only be caused by the increase in arterlal pressure after insplration, but might also be the result of a greater ventricular ejection force caused by the increased pliling of atrium and subsequent ventricle with the preceding forward flow surge in the venae cavae during inspiration.

This variabllity in cardiac filling with fetal breathing movements may partly account for the increased heart rate varlabllity found during fetal breathing movements (Dalton et al 1977, van der Wildt 1982). It Is very likely that these venous pulsations disrupt the preferential streaming pattern that exists in the vena cava inferior (paragraph 5.1), resulting in a greater mixing of the systemic venous blood from the vena cava and the umbllical venous blood at the juncture of the ductus venosus and the inferior vena cava. 
Isolated increases in intrathoracic pressure, referred to as expiratory effects by Dawes et al (1972), were accompanied by rises in intraabdominal pressure and decreases in unbllical venous flow and heart rate. They are in fact Valsalva-like manoeurres, present $e . g *$ during micturition, meconium discharge or grmanting.

Many factors detemine the variability in the fetal heart rate pattern. Flgure 7.9 for example shows a relation between changes in unbllical venous blood flow and fetal heart rate pattem. "The decreases in flow are probably caused by fetal movements, which may partially compress the umbllical vein. These periodic accelerations are in the human fetus regarded as a sign of a good fetal condition. Maybe the f'etus is touching or even pulling its umbilical cord at such a moment. The observations from this study show that fetal respiratory movements influence the blood flow pattem in the comon umblifical veln. The hemodynamic changes associated with fetal resplratory movements help to explain the phenomena occurring in the human fetal heart rate patterns during breathing movements. 



\section{CHAPIER VIII}

\section{EPILOGUE}

A retrospective view at the end of this stwdy on the questions addressed im chapter $I$ is sultable not only to judge whether an answer to the questions is obtained from the results but lt also offers an opportunity to suggest directives for future research.

The results reported in chapter III clearly show that umbilloal vernous blood flow during late decelerations in the fetal heant rate produced by uterine blood flow obstruction depends on the mean arterial blood pressure changes occurring during the late decelerations. The fetus whlch is capable of increasing 1ta blood pressure and thus malntainlng or even increasing 1 ts umbllical blood flow desplte the fall in heart rate probably has a greater reserve than the fetus who reacts with fall in blaod pressure and umbillcal blood flow.

It is very likely that the decrease in retal po, reached during the late deceleration is one of the major determinants of the fetal cardiovascular response.

Continuous measurement of fetal arterial $\mathrm{pO}_{2}$ by means of an Intravascular catheter might be a good method in future experiments to assess the "critical" $\mathrm{pO}_{2}$ leve1, at which the fetus Is no longer capable of malntalning its arterial blood pressure and umb111cal blood flow durling artiflelally produced late decelerations. Another Important research 1 tem is the placental vascular resistance. Additional measurement of unblilical venous pressure or vena cava inferlor pressure lis necessary for resistance calculations.

Qual iflication and quantification of the fetal heart rate pattern durine late decelerations with umbillcal venous blood flow lncrease respectively decrease misht furthemore possibly yield information of clinical interest in human obstetrics.The fact that instantaneous 
unblltcal blood Pow ls pulsatlle under varlous clrcumstances has been shom in chapter IIT, IV and $V$.

This phenomernor ls interesting from a physlologlcal polnt of view in that interference with preferential streaming in the vena cava might occur during pulsations in the venous flow posslbly leading to an enhanced mixing of oxygen poor blood from the lower part of the fetal body with oxygen rich blood from the placental side.

A more Intriguing finding is the decrease in uterine blood flow during umblltcal cord occlusions. Selectlve occlusions of elther both umblilical velns or both umbilical arteries by means af a special ocoluding device (de Haan at al 1976) will probably shed more light on the mechanim involved.

The effects of agonlsts and antagonists of the autonomic nervous system on umbllical blood flow are descrubed in chapter $\mathrm{V}$. The need for placental vascular resistance calculations was felt during the discussion of the blood flow changes. Future studies should be directed to the influence of clintcally important drugs as betasympathicomimetic tocolytic agents and betasympathicolytic antihypertensive drugs upon umblitoal blood flow and placental vascular resistance.

The question concerning the effect of acetylcholine, noreplnephrine and fenoterol on the maternal pelvic blood flow cannot be answered satisfylngly from the obtalned results, nor can a certain answer be derlved from the results whether any difference in the reaction pattem between internal 1 liac and median uterine artery blood flow exists. However a trend in the blood flow responses durthe the drug infusions was ascertalned. More experiments are necessary to answer this question.

Relatively little lis known about the effects of continuous administered beta-adrenergtc blocking drugs cpropranolol, atenolol, timolol, etcetera) or wterlne and umbllical blood fllow.

It might be worthwlle to study the effects of these group of drugs as we11 as the influences of other betasympathlcomlmetic drugs on the maternal and fetal blood flow. Maternal arterlal pressure and heart rate measurements as well as fetal venous pressure measurements must be 
included in the design of such a strudy.

The great influences of any form of fetal respiratory movement on umbllical venous blood flow is shown in the observations described in chapter VII.

Simultaneous measurements of umbllical venous blood flow, fetal venous and arterial pressure, heart rate and tracheal pressure over longer periods of time might bring in valuable information for the understanding of the mechanisms involved in the regulation of fetal heart rate variabillty. 



\section{APPENDIX}

\section{The autonomic nervous system}

The autonomic nervous system can be divided into its two classical components, the sympathetic and parasympathetic nervous systems, distinguished by differences in anatomy, distribution, chenlistry and function. The sympathetic nervous system is concerned with adaption to emergencies, the application of certain reflexes and the malntenance of sympathetic tone, while the parasympathetic tone is thought to be involved predominantly with the normal runing of bodily functions, partloularly digestion (Jones 1983).

The preganglionic neurons of both the sympathetic and parasympathettc system secrete acetylcholine as a transmltiter and this is true, too, of the parasympathetic postganglionic neurons. A few of the postganglionic endings of the sympathetic nervous system also secrete acetylchollne and these fibers ane cholinergic. By rar the majority of the sympathetic postganglionic endings secrete noreplinephrine, and these are said to be adrenerglc.

The sympathetic component of the autonomic nervous system can be further subd1vided by the concept of alpha and beta receptors, Introduced by Ahlquist (1948). Ahlquist proposed that alpha receptors mediated primarily excitation (contractile) responses such as vasoconstriction, excitation of the ureters and uterus and also one inhibltory response, gut relaxation. Beta receptors on the other hand were proposed to account malnly for inhlbitory responses such as vasodilatation, uterine relaxation and one excltatory response, cardiac stimulation.

Closely related adrenergic agents as norepinephrine, eplnephrine and Isoprenaline aiffer in their effects: norepinephrine acts malnly on alpha receptors, epinephrine acts roughly equally on both alpha and beta receptors whereas isoprenaline is almost wholly active at beta receptor sites. Lands et al (1967) made a subclassiflcation of the beta receptors in beta 1 and beta 2 receptors by comparing effector responses to a variety of catecholamines, which were active at the 
adrenergilc receptor site.

Beta 1 receptors mediate in the human for example relaxation of the intestinal mooth muscle, whereas beta 2 receptors mediate relaxation of vascular snooth muscle, relaxation of trachea and bronchi and also relaxation of the uterus. The difference in proportion of beta 1 and beta 2 receptor sites of for example the utemus enabled the development of beta 2 sympathicomimetic agents which can accomplish relaxation of the uterine smooth muscle with less adverse side effects towards predominantly beta 1 receptor containing organs.

Thesse agentis are now widely used as uterine relaxant in threatening premature labor in the human. 


\section{SUMMARY}

The present study deals with several aspects of matermal uterine and fetal umbllical blood f"low in a chronic lamb preparation in the latter third part of gestation.

In chapter I a general introduction is given on the various techniques in use for uterine and umbillcal blood flow measurement. The possibilities and limitations of the diffusion-equilibrium techique, the radioactlve microsphere method and electromagnetic flow transducers for uterine and umblitical blood flow measurements are described. The questions to be addressed in this study are formulated, preceded by introductory remarks from the literature on the topics involved.

In chapter II the surgical procedures used in this study in the chronto fetal sheep preparation are described as well as the methods of data acquisition, signal analysis and the expertmental plan.

In chapter III the effects of simulated late decelerations in the fetal heart rate caused by intermittent occlusion of the maternal common Internal iliac artery on umbilical venous blood flow in normoxemic fetal lambs are presented.

Late decelerations in fetal heart rate are generally considered to be a sign of fetal hypoxemia in human obstetrics and mostly occur in conditions in which the duration or the force of uterine contractions is too much for the fetus that is already at the $11 \mathrm{mits}$ of $1 \mathrm{ts}$ reserves, as e.g. In pre-eclampsia or chronically impaired placental. exchange.

The results of this study show that fetal umbllical venous blood flow may increase or decrease during late decelerations of the fetal heart rate caused by uterine blood flow obstruction.

The direction of the umbilical blood flow change is mainly determined by the concomitant change in arterial perfusion pressure, and to a lesser extent by the magnitude of the heart rate decrease.

The fetus which is capable of increasing 1ts blood pressure and thus 
melntalning or even lncreasing 1 ts umblilcal blood flow probably has a greater meserve than the fetus when reacts win a fall in blood pressure and umbl11cal blood rlow.

The occurrence of a blood pressure decrease during a late deceleration In splte of the very fast appearing chemoreceptor mediated peripheral. reflex vasoconstriction Implies a decrease in cardiac output, probably resulting from hypoxic myocardal depression, involving the sinoatrial node and heart muscle. Redistribution of cardiac output which is an Important retal mechanlsm to provlde high-prionlty tissues as heart and braln w1th enough blood at the expense of low-priority organs as e.g. viscera and musculoskeletal system, and which mechanism is associated with hypertension, is then endargered.

The determining factor in the fetal cardovascular response may be the degree of fetal hypoxemla which is reached during the uterine blood flow abstmotion.

Chapter IV deals with the effects of umbllical cord occlusions on umbllical venous and maternal pelvic blood flow.

Transient occlusion of the umbilical cord often occurs during labor in the human and leads to considerable changes in fetal hemodynamics. The results from the present study show that umblilcal cord occlusion also affects the matemal uterine blood flow. Shortlasting umblical cord occlustons are accompanied by a decrease in the blood flow in the maternal median uterine and internal illac artery at the slde of the pregnant horn.

Gradual. occlusion of the umbllical cord flrst leads to occlusion of the easy compressible umbllical velns. After a certaln lag time during whilch the surrounding pressure 1s increased, complete occlusion of the unb111cal arterles is accomplished too. Durlng this $1 \mathrm{ag}$ time a certain addstional amount of arterlal blood will be pumped into the umblilcal clrculation and will eventually be trapped in the umbliscal vascular bed under a high pressure after complete occlusion of the umblitical arteriers.

The elevated fetal capillary pressure in the placenta may lead to an Increased fetal placental tissue pressure which in tum compresses the matemal placental caplilaries resulting in an increased vascular 
resistance and a decrease in uterine blood flow.

A section of this chapter deals with the instantaneous umblitcal flow patterm during and after umbilical cord ocolusion.

The nomally non-pulsatile blood flow in the comnon umbllical veln changes to a flow pattem with blphasic pulsations in line with fetal heart rate during umbllical cord occlusion.

The pulsations are caused by backward propagation of the increased pulsatile flow pattern in the vena cava inferior during changes in heart rate and ventricular afterload. They may lnterfere with the mixing of umbilical venous and Inferlor vena caval blood and alter the distribution of oxygen-rich and oxygen-poor blood in the fetal heart.

Chapter $V$ presents the Influences of autonomic acting agents on umblilical venous blood flow. Varlous drugs which are related to the autonomic mervous system are used in human obstetrics (betamimetic and beta blocking arugs e.g.). The effects of these drugs on retal and maternal blood flow are only partly known.

Parasympathetic blockade with atropine increases umbillcal venous blood flow which is probably secondarlly caused by an increase in fetal heart rate. Alpha-adrenergic blockade with phentolamine causes peripheral. vasodilatation with fetal hypotension and a decrease in umbilical blood flow as result.

Beta-adrenergic blockade with propranolol is accompanied by a fall in umbilical blood flow whlch for the greater part can be explained by the conconftant fall in heart rate, although an increase in placental vascular resistance cannot be excluded.

Cholinemg1c stimulation with acetylcholine causes peripheral. vasodilatation with short lasting hypotension and a fall in umb11lcal blood flow*

Alpha-adrenergic stimulation with norepinephrine results in a mall. decrease in umbllical blood flow in the face of a serlous increase in perfusion pressure and a relatively small decrease in heart rate suggesting that umbilical vascular resistance increases.

Beta-adrenergic stimulation with fenoterol does not influence umbllical blood flow.

Changes in fetal heart rate and peripheral reststance occurring after 
acetylcholine and noreplnephrine administration result in biphasic pulsations in ine with fetal heart rate in the instantaneous umblilcal venous blood flow pattern. These pulsations may interfere with preiterential streaning in the vena cava inferior and thus influencing the 111 ing of the mght heart.

In chapter VI the effects of fenoterol, noreplnephrine and acetylcholine Infusion to the ewe on matemal pelvic and fetal umb111cal blood flow are described.

Beta-adrenergle receptor stimulation with fenoterol does in general not lead to slgnifloant changes in matemal blood flow although a relatively greater increase in matemal internal 11 lac than median uterine blood flow is observed, suggesting a greater sensitivity of the Intemal 11 lac artery than the median uterine artery or the vascular bed supplied by them to beta-adrenerglc receptor stimulation.

Alpha-adrenerglc receptor stimulation with norepinephrine causes a intial decrease in blood flow in both matemal vessels, which for the Breater part abates with time despite continued drug infusion.

No changes in maternal pelvic blood flow are observed during cholinergic receptor stimulation.

None of the infused drugs influences fetal umbllical bload fllow.

The results are compatible with blunting of the effects of autonomic vasoactive arugs on the uteroplacental and pelvlc vascular beds during pregnancy. This latter phenomenon is potentially protective for the fetus.

Chapter VII deals with the Influences of fetal breathing movements on umb111cal venous blood flow. Fetal breathlng movements causes undulatory changes in umbllical venous blood flow.

An Insplratory movement, characterized by a fall in tracheal pressure is accompanted by a decrease in umblllcal venous blood flow. This decrease in umbllical venous blood flow during Insplration 1 s caused by the concomitant Increase in Intraabdominal pressure assoclated with the paradoxical fetal breathing movement. Other fetal respiratory movements as 1solated deep breaths and gasplng as well as other phenomena as 
grunting, Valsalva-like manoeuvres or hiccups which are assoclated with intrathoracic and intraabdominal pressure changes also have a marked influence on umbllical venous blood flow.

Instantaneous changes in the blood flow returning to the fetal heart may lead to a variability in cardiac fllling partly accounting for the increased heart rate variability during fetal breathing movements. Knowledge on the hemodynamic changes associated with fetal respiratory movements help to explain the phenomena occurring in the human fetal heart rate pattern.

In chapter VIII a retrospective view is given on the adressed questions in the present study and some directives for future research are suggested. 


\section{SAMENVATING}

In dit proefschrift worden verschillende aspecten van de maternale uterlene en foetale umbilicale bloed flow in het chronisch schapepreparaat beschreven.

In hoofdstuk I wordt een algemene beschouwing gegeven over de diverse technleken die gebrulkt worden voor het meten van de uterlene en umblifcale bloed flow. De mogellykeden en beperkingen van de diffusle-equilibrium techniek, de radio-actieve microsfeer methode en van de electromagnetische flow meting worden besproken.

Finfe discusslepunten ult de literatuur welke van belang aljn voor de vraagstellingen van het onderzoek worden aangehaald.

In hoofdstuk II worden de gebrulkte chirurgische technieken in dit chrontsch schapemodel besproken evenals de methode van dataverwerking en signaalanalyse en het experimentele plan.

In hoofdstuk III worden de effecten van gesImuleerde late deceleraties in het foetale hartirequentlepatroon, veroorzaakt door Intermitterende afsiultug van de maternale arterla lliaca Interna commuls, op de umblilcale vemeuze flow in normoxemische foetale lanmeren beschreven. Late deceleraties bly de mens worden beschouw als een teken van foetale hypoxemie. Z1j komen veelal voor in s1tuatles waarin de foetus de extra belasting die weebnactivitelt vomt voor het placentadre zumistof transport nlet meer kan opvangen zoals b1.j acute of chronlsche placenta insufficientile.

De resultaten van dit onderzoek laten zlen dat de foetale umblilcale flow tijdens late deceleraties kan toenemen dan wel afnemen.

Deze toe- of afname in umbl11cale flow is hoofdzakelifk afhankelijk van de tegel1jkert1jd optredende veranderingen in de foetale arterlële perfusle druk en in mindere mate van de hartfrequentiedaling.

De foetus die zijn bloeddruk kan verhogen en derhalve ziljn umbllicale bloed low kan handhaven of zelfs doen toenemen, heeft waarschijniljk een grotere reserve dan de foetus die reageert met een bloedarukdaling 
en een aframe van de umbillcale flow.

Fen bloeddrukdaling tijdens een late deceleratie ondanks de snel in werking tredende perifere vasoconstrictie houdt een afname van het hartminuut volume in, warschijnlijk tengevolge van hypoxemsche depressle van het myocardium, waaronder sinusknoop en hartsplervezels. Het belang 1 jke foetale adaptatie mechanisme, namelijk de redistributie van het hartminuutvolume, welke de foetus in staat stelt on belangrijke organen als hart en hersenen van voldoende bloed te voorzlen twen koste van organen als de ingewanden, de spleren en het skelet, mist dan de noodzakelijke bloedarukst Ijging. De foetale hypoxemie die bereikt worat tijdens de obstruktie van de uteriene bloed voorzianing is warschifnlijk de belangrifkste factor bij het bepalen van de foetale cardlovasculaitre respons.

In hoofdstuk IV worden de effecten van navelstreng afklemingen op de umbilicale veneuze en matemale bloed flow in het kleine bekken beschreven.

Afkleming van de navelstreng 1 s een veel voorkomend verschiljnsel. tijdens de baring blj de mens dat aanzlenlijke veranderingen in de foetale circulatie veroorzaakt.

De gepresenteerde resultaten later zien dat navelstrengafkleming ook leldt tot veranderingen in de moederiljke utericene bloed flow.

Kortdurende navelstrengafklemingen gaan gepaard met een afname in de flow in de maternale arteria uterina mediana en illac intema aan de zllyde van de drachtige uterushoorn.

Geleldelifke afklemming van de navelstreng veroorzaakt eerst een afklenmen van de gemakkelifk samendmukbare navelstrengvenen. Een zekere tijdspanne is rodif voor het opbouwen van voldoende druk or ook de navelstrengarteriën dlcht te drukken.

Een bepaalde hoeveelheid arterieêl bloed zal extra in de umbillcale clrculatle worden gepompt in deze tijdspanne en deze hoeveelheld wordt uitelndelijk onder hoge druk gevangen in het umbllicale varatbed na complete afkleming wan de navelstrengarterién.

Er ontstaat een verhoogdie foetale caplllaire druk in de placenta met een toegenomen foetale placentalre weefseldruk welke op zifn beurt de maternale placentalre capilialren samendrukt met een verhoogde 
vaatweerstand en een dallng van de matemale uteriene flow als gevolg. Verder wordt in dit hoofdstuk het flowpatroon in de vena umblicalls commuls beschreven tijdens en na navelstrengafklemingen.

De flow in de vena umbllicalis commuls welke gewoonllyk zonaer pulsaties 1s, vertoont tijdens navelstrengafklemming bifasische pulsat1es in 11.jn met de foetale hartrequentie.

De pulsatles worden veroorzaakt door het voortgelelden van flowpulsaties in de vena cava inferlor welke toenemer in amplitudo tIJdens veranderingen in hartfrequentie en perifere vaatweerstand. Deze pulsaties kunnen interfereren met de menging van het veneuze umbilicale en vena cava Inferlor bloed en op deze wijze de verdeling van zuurstorr $1 \mathrm{jk}$ en zuurstofarm bloed in het roetale hart belnvloeden.

In hoofdstuk $W$ wordt de invloed van agonlsten en antagonisten van het autonome zenuwstelsel op de umb1licale veneuze bloed flow beschrewen. In de humane obstetrie wordt veel gebrulk gemaakt van aan het autonome zenuwstelsel gerelateerde medicamenten (betamimetica, beta-blokkers). De effecten van deze medicamenten op de foetale en maternale bloed flow z1. yn grotendeels onbekend.

Blokkade van het parasympatische zenuwstelsel met atropine veroorzaakt een toename van de umb111cale veneuze flow waarschilnl1 jk secundair aan de toename in hartif requentie.

Beta-adrenerge blokkade met propranolol gaat gepaard met een daling van de umblicale Flow. Deze afname in flow kan voor een groot deel veroorzaakt worden door de gelijktljalge hartfrequentie daling, hoewel een toename van de placentalre vatweerstand niet kan worden ult tgesloten.

Stimulatie van het parasympatische zenuwstelsel met acetylcholine verooradakt perifere vasodllatatie met een kort durende hypotensie en een afname in umbllicale flow.

Alpha-adrenerge stimulatile met roradrenaline resulteert in een geringe afname van de umbllicale flow. Het gelljktijdig optreden van een aanzlenl1jke toename in de perfusledruk en een relatief geringe daling van de hart frequentle suggereert dat de placentafre vatumeerstand toeneernt.

Beta-adrenerge stimulatie met fenoterol heeft geen invloed op de 
unblilcale flow.

Weranderingen in foetale hartrequentie en perifere weerstand na toediening van acetylcholine en nomadmenaline gaan gepaard met bifasische pulsaties in het umbilicale flow patroon met dezelfde frequentie als de hartslag. Deze pulsatles kunnen de workeursstroning in de vena cava inferior beinvioeden en derhalve het vullingspatroon var het foetale hart.

In hoofdstuk VI worden de effecten van contimue toedienIng van fenoterol, moradrenaline en acetylcholine aan de ool op de moederlijke bloed flow in het kleine bekken en op de foetale umblllcale flow beschreven.

Beta-adrenerge receptor stimulatie met fenoterol veroorzaakt in het algemeen geen signiflcante veranderingen in de matennale flow hoewel een relatief grotere toename in de flow optreedt in de arteria 11 laca interna dan in de arteria uterlna mediana, hetgeen een grotere gevoeligheid van de arteria illaca uterina dan van de arteria uterina medlana en hun beider vaatbed voor beta-adrenerge receptor stimulatie suggereert.

Alpha-adrenerge receptor stimulatie met moradrenaline veroorzaakt aanvankelijk een daling in de flow in belde vaten, doch de flow herstelt geleldel1.jk ondanks het continueren van de noradrenaline infusie.

Cholinerge receptor stimulatie met acetylcholine leidt niet tot verandering in de moederlijke flow.

De umblicale flow vertoont geen veranderingen tijdens maternale Infusle met een der drle famaca.

De resultaten wijn in overeensterming met een verminderde gevoeldghela van het vaatbed wan het kleine bekken tljdens de zwangerschap woor vasoactieve farmaca welke het autonome zenuwstelsel belnvloeden. Mogel1 jk gaat hiervan een beschemend effect voor de foetus ult.

In hoodfstuk VII wordt de Irviloed van foetale ademhalingsbeweglngen op de umblicale veneuze bloed flow gepresenteerd.

In de humane obstetrie worden de foetale ademhalingsbewegingen mede gebrulkt voor het bepalen van de foetale condltle. Tevens is het bekend 
dat de ademhallngsbewegingen lrvloed hebben op de snelle variatles in het foetale hartrequentiepatroon.

Foetale adenbewegingen veroorzaken golfbewegingen in de umbillcale veneuze bloed flow. Fen inademingsbeweging welke gekarakteriseerd wordt door een daling van de druk in de trachea, gat gepaard met een afname In de umbllicale veneuze flow. Deze afname in umblicale weneuze flow tidens Insplratie wordt veroorzakat door de gelljkt1jalge toename van de Intraabdoninale druk tijdens de paradoxe foetale adembewegingen. Andere foetale resplratolre beweglngen zols gelsoleerde diepe adembeweglngen en gaspen evenals fenomenen als Valsalva-achtige manoeuvres, hikken en meconlum lozen dle geassocleerd zijn met Intrathoracale en Intraabdominale drukveranderingen beinvloeden de umblilcale veneuze flow eveneens.

Veranderingen in de veneuze flow naar het foetale hart kunnen leiden tot schomilingen in de vulling van de rechter harthelft, welke gedeeltelijk verantwoordel1jk kunnen zijn voor de toegenomen varlablliteit in het foetale hartrequentiepatroon tijdens foetale adembeweg1ngem. Kennis van de haemodynamische veranderingen tijdens foetale resplratolre bewegingen geven meer inzicht $1 n$ de fenomenen die optreden in het antenale hart frequentie patroon.

In hoodfstuk VIII vindt een korte terugblik plaats op de vraagstellingen en worden suggesties gedaan voor toekomstig onderzoek. 


\section{REFEREWCES}

Aarnoudse, J.G.

Oxygen tension in the fetus. Contimuous measurement of fetal subcutaneous $\mathrm{pO}_{2}$ with a needle electrode.

An experimental and clinical investigation.

Thesis, State University Groningen, The Netherlands, (1980). Adams, F.M., Assal1, N., Cushman, M., Westersten, A.

Interrelationships of matemal and fetal circulations.

Pediatrics 27:627 (1961).

Anlfeld, $F$.

Ueber bisher noch nicht beschrlebene Intrauterine

Bewegungen des Kindes.

Verh. Dtsch. Ges. GJmäk. 2:203 (1888).

Ahlquist, R.P., and Woodbury, R.A.

Influence of drugs and uterine activity upon

uterine blood flow.

Fed. Proc. 6:305 (1947).

Ahlquist, R.P.

A study of the adrenotropic receptors.

Am. J. Physiol. 153:586 (1948).

Assal1, N.S., Douglass, R.A., Ba1rd, Jr. W.W., N.tcholson,

D.B., Suyemoto, R.

Measurement of uterine blood flow and uterine metabolism.

IV. Results in nomal pregnancy.

Am. J. Obstet. Gymecol. 66:248 (1953).

Assali, N.S., Rauramo, L., Peltonen, "I.

Measurement of uterine blood Flow and uterine metabollsm.

VIII. Uterine and fetal blood flow and oxyeri consumption

In early human pregnancy.

Arm. J. Obstet. Gynecol. 79:86 (1960).

Assali, N.S., Morris, J.A., Beck, R.

Cardiovascular haemodynamics in the fetal lamb before and after lung expansion. 
Am. J. Phys1ol. 208:122 (1965).

Assal1, N.S., Brinkman, C.R. III.

The uterine circulation and 1ts control.

In: Respiratory gas exchange and blood flow in the placenta pag 121-141

Ed: L.D. Longo and H. Bartels. :

Publication of the U.S. Department of Health,

Education and Welfare. No. 73-361 (1972).

Assali, N.S., Brinkman, C.R., III, Nuwayhid, B.

Comparison of maternal and fetal cardlovascular functions

in acute and chronic experiments in the sheep.

Am. J. Obstet. Oynecol. 120:411 (1974).

Assal1, N.S., Nuwayhtd, B., Brinkman, C.R., III, Tabsh, K.,

Erkkola, R., Ushioda, E.

Autonomic control of the pelvic circulation: in vivo and

in vitro studies in pregnant and nonpregnant sheep.

Am. J. Obstet. Gynecol. 141:873 (1981).

Astley, C.A., Hohimer, A.R., Stephenson, R.B., Smith, O.A.,

Spelman, F.A.

Effect of implant duration on in vivo sensitivity of

electromagnet1c flow transducers.

Am. J. Phys1ol. 236:H508 (1979).

Ayromioo1, J., Tobłas, M., Desiderio, D.

Effects of isoxsuprine on maternal and fetal acid-base

balance and clrculation.

Am. J. Obstet. Gynecol. $57: 193$ (1981).

Ayromlool, $J$.

Eiffect of propranolol on the ac1d-base balance and hemodynamics of "chronlcally instrumented" pregriant sheep.

Dev. Pharmacoll. Ther. 6:207 (1983).

Baker, D.W., Johnston, S.L., Strandness, Jr. D.E.

Prospects for quant1tation of transcutaneous pulsed

Doppler techniques in cardiology and peripheral

vascular disease, pag. 108-124

In: Cardlovascular Applications of UItrasound. 
Ed. R.Reneman. North-Holland, Publ. Co. (1974). Barcroft, J., Herkel, W., Hill, S.

The rate of blood flow and gaseous metabolism of

the uterus during pregnancy.

Am. J. Phys1ol. $77: 194$ (1933).

Barcroft, J.

Researches on pre-natal life. (Blackwell, Oxford) (1946). Barrett, C.T., Heymann, M.A., Rudolph, A.M.

Alpha and beta-adrenergic receptor activity in fetal sheep.

Am. J. Obstet. Gynecol. 112:1114 (1972).

Barton, M.D., Killam, A.P., Meschia, G.

Response of ovine uterine blood flow to epinephrine

and norepinephrine.

Proc. Soc. Exp. B1ol. Med. 145:996 (1974).

Bauer, D.J.

The slowing of heart rate produced by clamping the umblilical cord in the foetal sheep.

J. Physiol. (Lond.) 90:25P (1937).

Béclard, P.A.

Untersuchungen welche zu beweisen scheinen dass der Fetus das Schafwasser athmet.

Dtsch. Arch. Physiol. 1:154 (1815).

Behrman, R.E., Lees, M.H., Peterson, E.N., Delannoy, C.W.,

Seeds, A.E.

Distribution of the clrculation in the normal and asphyxiated fetal primate.

Am. J. Obstet. Gynecol. 108:956 (1970).

Bell, C.

Distribution of cholinergic vasomotor nerves to the parametrial arteries of some laboratory and domestic animals. J. Reprod. Fert1l. 27:53 (1971).

Bell, C.

Autonomic nervous control of reproduction:

circulatory and other factors.

Pharmecol Rev. 24:657 (1972). 
Be11,

Control of utemine blood flow in pregnancy.

Medical BLology 52:219 (1974).

Eerman Jr. W., Goodlin, R.C., Heymann, M.A., Rudolph A.M.

Measurement of unblifcal blood flow in fetal lambs in utero.

J. App1. Phys 101. 19:1056 (1975).

Beman Jr. W., Goodlin, R.C., Hejmann, M.A., Rudolph, A.M.

Relationship between pressure and flow in the umbilical.

and uterine circulation of the sheep.

Clre. Rex. 38:262 (1976).

Beman Jr. W., Goodiln, R.C., Heymann, M.A., Rudolph, A.M.

Fefects of phamacologic agents on umbllical blood flow

in fetal lambs in utero.

Blo1. Neonate 33:225 (1978).

Blissonmette, J.M., Farreld, R.C.

Pressure-flow and pressure-volume relationships in the fetal

placental circulation.

J. Appl. Fhystol. 35(3):355 (1973).

Boddy, K., Roblnson, J.S.

External method for detection of fetal breathing in utero.

Iancet $2: 1231$ (1971).

Boddy, K., Dawes, G.S., Flsher, R., Pinter, S., Robinson, J.S.

Fetal resplratory movements, electrocortical and

cardLovascular responses to hypoxaemia and hypercapnla

in sheep.

J. Phystol. (Lond.*) 243:599 (1974).

Bodlly, K.C., PhIllips, D.J., ThLele, B.L., Strandness Jr. D.E.

Noninvasive detection of intemal carotid artery occlusion.

Anglology 32:517 (1981).

Borst, $\mathrm{C}$

Arculatory effects of electrical stimulation of the carotid slmus nerves in man. A physlologlcal study.

Thes1s, Unlversity of Ansterdam (1979).

Bott1, J.J., Edelstone, D.I., Caritis, S.N., Mueller-Heubach, E.

Pontal venous blood flow distribution to liver and

ductus venosus in newborn lambs. 
AJ. Obstet. Gynecol. 144:303 (1982).

Bots, R.S.G.M.

Onderzoek van de adembewegingen van de ongseborene met behup van de multiscanM-mode echografie.

Thesis, Free University Amsterdam, The Netherlands (1977). Bots, R.S.G.M., Jongsma, H.W., Braat, A.J.H.M.,Martin, C.B., de Haan, $J$.

Human fetal breathing movements and heart rate variability. In: Proceedings Fifth Conference on Fetal Breathing pag. 45, Catholic University Ni Jmegen, "The Nether"lands (1978). Brennan, S.C., MoLaughi.in, M.K., Chez, R.A.

Effects of prolonged infusion of beta-adrenergic agonists on uterine and umbilical blood flow in pregnant sheep.

Am. J. Obstet. Gynecol. 128:709 (1977). Breslau, P.J.

Ultrasonic duplex scanning in the evaluation of carotid artery disease.

Thesis, State University Limburg, Maastricht,

The Netherlands (1982).

Bretscher, J.

Fehler und Irrtum bei pH-analysen von Microblutproben. Gynaecologia 162:369 (1966).

Bruins Slot, $\mathrm{H}$.

Doppler studies in the femoro-popliteal pathway. Thesis, State University Limburg, Maastricht, The Netherlands (1981).

Caldeyro-Barcia, R., Poseiro, J.J., Negrelros de Palva, C. Gonez-Rogers, C., Faundes-Latham, A., Zambrana, M.A., Arellano-Hernandez, G.

Effects of abnomal uterine contractions on a human letus.

Mod. Probl. Pedlat. 8:267 (1963).

Campogrande, M., Alemanno, M.G., V1ora, E., Bussolino, S.

FHR short and long tern varlability assoclated with

fetal breathing

J. Perinat. Med. 10:203 (1982). 
Caton, D., Abrams, A.R., Clapp, J.F., Barron, D.H.

The effect of exogenous progesterone on the rate of blood

flow of the uterus of ovariectomized sheep.

Q.J. Exp. Phys1ol. 59:225 (1974).

Chapman, R.L.K., Dawes, G.S., Rurak, D.W., Wilds, P.L.

Breathing movements in fetal lambs and the effect of hypercapnia.

J. Physio1. 302:19 (1980).

Charbon, G.A., van der Mark, F.A.

Use of electromagnet1c flowmeters for the study

of splanchnic blood flow.

In: Granger, D.N., Bulkley, G.B. Measurement of blood flow,

application to the splanchnic circulation pag.125-155

Ed. Willams \& Wilkins, Baltimore, Iondon (1981).

Chez, R.A., Ehrenkranz, R.A., Oakes, G.K., Walker, A.M.

Hamilton Jr. L.A., Brennan, S.C., McLaughlin, M.K.

Effects of adrenergic agents on ovine umbilical and

uterine blood flows.

In: Fetal and newborn cardiovascular physLology, Volume 2:

Fetal and newborn circulation, pag. 1-16

Ed. L.D. Longo \& D.D. Reneau, Garland Press,

New York (1978).

Chiba, Y., Hasegawa, T., Aoki, M., Sakakibara, S., Sasaki, K.,

Irle, M., Kuracht, K.

Real-time measurements of fetal blood flow and the change of the flow velocity in umblical veln by fetal breathing movements. Acta Obstet. Gynecol. Japonica. pag. 2331 (1981).

Clapp, J.F.

Cardlac output and uterine blood flow in the pregnant ewe.

Am. J. Obstet. Gynecol. 130:419 (1978).

Clapp, J.F.

Placental bed blood flow in the pregnant ewe.

In: Placental 'Transf'er.

Ed. Chamberlain, G., Wilkinson, A. pag.60-75

Pitman Medical Publishing Co. IID, Kent, England (1979).

Cohn, H.E., Sacks, E.J., Heymann, M.A., Rudolph, A.M. 
Cardlovascular responses to hypoxemia and acidemia in Petal lambs. An. J. Obstet. Gynecol. 120:817 (1974).

Cohn, H.E., Plaseckl, G.J., Jackson, B.T.

The effect of fetal heart rate on cardiovascular funotlon

during hypoxemila.

Am. J. Obstet. Gynecol. 138:1190 (1980).

Cohn, H.E., Plasecki, G.J., Jackon, B.T.

The effect of beta-adrenergic stimulation on fetal

cardiovascular function during hypoxemla.

Am. J. Obstet. Gynecol. 144:810 (1982).

Cohnstein, J., Zuntz, N.

Untersuchumgen uber das Blut, den Krelslauf and die Athmung belm saugethier Fötus.

Pflügers Arch. Ges. Physiol. 34:173 (1884).

Comilne, R.S. * Silver, I.A., Sllver, M.

Factors responsibie for the stimulation of the adrenal.

medulla during asphyxla in the foetal lamb.

J. Physiol. 178:211 (1965).

O"Connor, M.C., Hytten, F.E.

Measurement of fetal transcutaneous oxygen tension.

Problems and potential

Brit. J. Obstet. Gynaecol. 86:948 (1979).

Cooper, K.E*, Greenfleld, A.D.M.,

A method for measurting the blood flow in the umbilical

vessels.

J. Physilol. 108:167 (1949).

Cottle, M.K.W. van Petten, G.R., van Muyden, P.

Depression of uterine blood flow in response to

cord compression in sheep.

Can. J.Phys 10l. Phamacol. 60:825 (1982).

Cottle, M.K.W., Van Petten, G.R., van Muyden, P.

Maternal and fetal cardlovascular indlces during fetal

hypoxia due to cord compression in chronically cannulated sheep.

II. Responses to promazine.

Am. J. Obstet. Gynecol. 146:686 (1983). 
Dalton, K.J., Dawes, G.S., Patrick, J.E.

Diurmal, resplratory and other whythms of fetal heart rate in lambs.

An. J. Obstet. Gynecol. 127:414 (1977).

Dawes, G.S., Mott, J.C.

Changes in $\mathrm{O}_{2}$ distribution and consumption in fetal

lambs with variations in umblilical blood flow.

J. Physiol. 170:524 (1964).

Dawes, G.S.

Foetal and neonatal physiology : A comparative study

of the changes at birth.

Year book medical publishers, Chicago (1968a). Dawes, G.S., Lew1s, B.V., Milligan, J.E., Roach, M.L.

Talner, $\mathrm{N}$.

Vasomotor responses in the hind limbs of foetal and

newborn lambs to asphyxia and aortic chemoreceptor stimulation.

J. Phys101. (Lond.) 195:55 (1968b).

Dawes, G.S., Duncan, S.L.B., Lew1s, B.V., Merlet, C.L.,

Owen-Thomas, J.B., Reeves, J.T.

Hypoxemia and aortic body receptor function in foetal

lambs.

J. Physiol. (Lond.) 201:105 (1969).

Dawes, G.S., Fox, H.E., Leduc, B.M., Liggins, G.C.,

Richards, R.T.

Resplratory movements and paradoxical sleep in the foetal lamb.

J. Praysiol. 210:47 (1970).

Dawes, G.S., Fox, H.E., Leduc, B.M..., Liggins, G.C.,

Richards, R.?.

Resplratory movements and rapid eye movement sleep in the foetal lamb.

J. Phys1ol. 220:129-143 (1972).

Dawes, G.S., V1sser, G.H.A., Goodman, J.D.S., Levine, D.H. Numerical analysis of the human fetal heart rate: 
modulation by breathing and body movements.

Am. J. Obstet. Gynecol. 140:535 (1981).

Dilts Jr. P.V*, Brinkman, C.R. III, Kirsehbaun, T. H. Astall, N.S.

Uterine and systemic hemodynamic interrelationships and

their response to hypoxia.

Am. J. Obstet. Gynecol. 103:138 (1969).

Edelstone, D.I., Rudolph, A.M., Heymann, M.A.

Liver and ductus venosus blood flows in fetal lambs in uters.

Circulation research 42/3:426 (1978).

Edelstone, D.I., Rudolph, A.M.

Preferential streaming of ductus venosus blood to the

brain and heart in fetal lambs.

An. J. Physiol. 237:H724 (1979).

Edelstone, D.I., Rudolph, A.M., Heymann, M.A.

Effects of hypoxemia and decreasing umblical flow

on liver and ductus venosus blood flows in fetal lambs.

Am. J. Physiol. 238:11656 (1980a).

Edelstone, D.I., Merick, R.E., Caritis, S.N., Mueller-Heubach, E.

Umbilical venous blood flow and its distribution before and

during autonomic blockade in fetal lambs.

Am. J. Obstet. Gynecol. 138:703 (1980b).

Ehinger, B., Gennser, G., Owman, Ch., Persson, H., Sjbberg, N.o.

Histochemical and pharmacolog 1 cal studies on amine mechanisms 1 m

the umbilical cord, umbilical vein and ductus venosus of the human fetus.

Acta Phys1ol. Scand. 72:15 (1968).

Ehrenkranz, R.A., Walker, A.M., Oakes, G.K., McLaughlin, M.K.,

Chez, R.A.

Effect of ritodrine Infusion on uterine and umbilical blood

flow in pregnant sheep.

Am. J. Obstet. Gynecol. 126:343 (1976).

Ehrenkranz, R.A., WaIker, A.M., Oakes, G.K., Hamilton Jr. L.A.,

Chez, R.A.

Effect of fenoterol (Th 1165a) Infusion on utertine and 
umbillcal blood plow in pregnant sheep.

Am. J. Obstet. Gynecol. 128:177 (1977a).

Ehrenkranz, R.A., Hamilton Jr. L.A., Brennan, S.C., Dakes, G.K.,

Walker, A.M., Chez, R.A.

Effects of salbutamol and 1soxsuprine on uterine and umbllical blood flow in pregnant sheep.

Am. J. Obstet. Gynecol. 128:287 (1977b).

E1k-Nes, S.H., Brubakk, A.O., Ulstein, M.

Measurement of human fetal blood flow.

Br. Med. J. 208:283 (1980).

E1K-Nes, S.H., Marsal, K,.., Brubakk, A.O., Krlstoffersen, K.,

Ulstein, M.

Ultrasonic measurement of human fetal blood flow.

J. Blomed. Eng. 4:28 (1982).

Erkkola, R., Tabsh, K., Ush1oda, E., Nuwayh1d, B., Brinkman,

C.R. III, Assali, N.S.

Responses of the pelvic vascular bed to intraarterial

stimulation of beta-adrenergic and cholinergic

receptors in pregnant and nompregnant sheep.

Am. J. Obstet. Gymecol. 141:599 (1981).

Evers, J.L.H.

The cardiac pre-ejection perlod during prenatal life.

Studies in stressed and unstressed fetal lambs.

Thesis, Cathol1c University NiJmegen,

The Netherlands (1978).

Fouron, J.C., Korzac, Y., Leduc, B.

Cardlovascular changes assoclated with fetal breathing.

Am. J. Obstet. Gynecol. 123:868 (1975).

Fuller, E.0., Galett1, P.M., Tachench1, T.

Major and collateral components of blood flow to the

pregnant sheep uterus.

Am. J. Phys101. 229:272 (1975).

Fuller, E.O., Manning, J.W., Nutter, P.O.

A perfused uterine preparation for the study of uterine and fetal physlology. 
In: Fetal and newbom cardiovascular physiology, Volume 2:

Fetal and newborn circulation. par. 421-435

Ed. L.D. Longo \& D.D. Reneau, Garland Press,

New York (1978).

Galenus,

Opera omnia.

Ediderunt Andreas Asulanus et J.B. Oplzo.

5 vols. In aedibus Ald1, et Andreae Asulani soceri.

Venetis. (1525).

Goodman, I.S., Gilman, A.

The phamacological basis of therapeutics.

MacMillan, New York (1980).

Goodman, J., Mantell, C.

Two means of measuring fetal breathing movements by

the Doppler method.

Proceedings of the fifth conference on fetal breathing.

Catholic University Nijmegen, The Netherlands (1978). Gordon, A.S.

Practical aspects of blood flow measurement.

Ed. "Statham Instruments Inc."

2230 Statham Boulevard. Oxnard. California 93030 (1971). Gough, J.D., Poore, R.

Directional Doppler measurements of foetal breathing.

J. Physiol. 272:12. (1977).

Greenfteld, A.D.M., Stepherd, I.T., whelan, F.T.

The rate of blood flow in the umbilical cond.

The Lancet 2:422 (1951).

Grelss, F.C.

A mechanical zero reference for implanted flowmeter systems.

J. Appl. Phs1ol. 17:177 (1962).

Grelss, F.C.

The uterine vascular bed: Effect of adrenergic stimulation.

Obstet. Gynecol. 21:295 (1963).

Greiss, F.C., Pick, J.R.

The uterine vascular bed: Adrenergic receptors. 
Obstet. Gynecol. 23:209 (1964).

Grelas, F.C., Marston, E.L.

The uterthe vascular bed: affect of estrogens

during ovine pregnancy.

Am. J. Obstet. Gynecol. 93:720 (1965).

Grelss, F.C.

Pressure flow relationship in the gravid uterine vascular bed.

Am. J. Obstet. Gynecol. 96:41 (1966).

Greiss, F.C., Gobble, F.L.

Effect of sympathet1c nerve stimulation on the

uterine vascular bed.

Ann. J. Obstet, Gynecol. 97:962 (1967a).

Grelss, F.C., Gobble, F.L., Anderson, S.G., McGuirt W.F.

Effect of parasympathetic nerve stimulation on the

uterine vascular bed.

Am. J. Obstet. Gynecol. 99:1067 (1967b).

Grelss, F.C., Gobble, F.L., Anderson, S.G., McGulrt, W.F.

Effect of acetylcholine on the uterine vascular bed.

Am. J. Obstet. Gynecol. 99:1073 (1967c).

Grefss, F.C., Anderson, S.G.

Uterine vascular changes during the ovarian cycle.

Am. J. Obstet. Gynecol. 103:629 (1969).

Grelss, F.C., Anderson, S.G.

Effect of ovarian homones on the uterine vascular bed.

Am. J. Obstet. Gynecol. 107:829 (1970).

Greliss, F.C.

Differential reactivity of the myoendonetrial and

placental vasculatures: Vasodilatation.

Am. J. Obstet. Gynecol. 111:611 (1971).

Grelss, F.c.

Differential reactivity of the myoendometrial and

placental vasculatures: Adrenergic responses.

Am. J. Obstet. Gynecol. 112:20 (1972).

Gre1ss, F.C., St11l, J.G., Anderson, S.G.

Eiffects of local anesthetic agents on the uterine 
vasculatures and myometrium.

Am. J. Obstet. Gymecol. 124:889 (1976).

de Haan, I., Eskes, T.K.A.B., Arts, T.H.M., van der Hoek, J.M.

The fetal and matemal acid base balance in sheep durlng acute (total or epidural anesthesia) and during chronic experiments.

Perinatale Medizin, Band VI pag. 199

Ed. J.W. Dudenhausen, E. Saling, E. Schmidt.

Georg. Thieme Verlag Stuttgart (1975).

de Haan, J., Jongsma, H.W., Crevels, A.J., Arts, T.H.M.

The cardiovascular effects following compression of the umbilical veins and/or arteries in chronlc sheep preparation.

In: Abstracts of free communications

Fifth European Congress of perinatal medicine, pas. 50

Ed. G. Rooth, Almquist and WIkse11 intemational,

Strockholm (1976).

de Haan, J., Martin, C.B., Evers, J.L.H., Jongsma, H.W.

Pathophysiologic mechanlsms underlying fetal heant rate patterms.

Perinatal Medicine, pag. 200-215

Ed. Thalharmer, 0., Baumgarten, K., Pollak, A.

George Thieme publishers Stuttgart (1979).

Hammacher, $\mathrm{K}$.

Neue Methode zur selektiven Reglstrlerung der fetalen

Herzschlagf requenz.

Gebutsh. und Frauenhe11k. 22:1542 (1962).

Harding, R., Johnson, P., McClelland, M.E. et al.

Larymgeal function durlng breathing and swallowlng

In foetal and newbom lambs (abstract).

J. Physiol. (Lond.) $272: 14$ (1977).

Harris, J.L., Krueger, T.R., Parer, J.T.

Effect of parasympathet $1 \mathrm{c}$ and beta-adrenergic blockade

on the umblifcal circulation in the unanesthetized retal. sheep.

Gynecol. Obstet. Invest. 10:306 (1979). 
Harris, J.L., Krueger, T.R., Parer, J.T.

Mechanlsms of late decelerations of the fetal heart rate during hypoxia.

Am. J. Obstet. Gynecol. 144:491 (1982).

Harvey, W.

Exercltatio anatomlca de motu cordis et sanguinis

In animalibus.

Francofurt1, sumpt. G. F1tzeri, (1628). Harvey, W.

Exercitationes de Generatione animalium.

Londint (1651).

Hasaart, T.H.M., de Haan, J.

Reflections of fetal thoracal movements in the blood flow

measurements of the common umbllical veln in the chronic sheep preparation.

Abstracts ninth conference on fetal breathing movements and

other f"etal measurements. London Ontario Canada (1982). Hasaart, T.H.M., de Haan, J.

Blood flow patterns in the common umbilical vein in

fetal sheep.

Abstracts tenth conference on fetal breathing novements

and other fetal measurements. pag. $39 \mathrm{Malmö}$, Sweden Hasaart, T.H.M., de Haan, J.

Pelvic blood flow and postural changes in pregnant sheep.

Abstracts tenth conference on fetal breathing movements and other fetal measurements.

pag. 103, Malmö, Sweden (1983b).

Heythann, M.A., Rudolph, A.M.

Effect of exteriorization of the sheep fetus on its

cardiovascular function.

Circ. Res. 21:741 (1967).

H11l, L.M., Breckle, R., Wolfgram, K.R.

An ultrasonic view of the developing f'etus.

Obstetr1cal and Gynecological Survey 38:375 (1983).

Hon, E.H.., Hess, O.W.

The clinical value of fetal electrocardiography. 
Am. J. Obstet. Gynecol. 79:1012 (1960).

Hon, E.H.

Electronic evaluation of the fetal heart rate.

VI. Fetal distress-a working hypothesis.

Am. J. Obstet. Gynecol. 83:333 (1962).

Hon, E.H.

An atlas of fetal heart rate patterns.

Harty Press Incorporated, New Haven.

Connecticut U.S.A. (1968).

Huch, A., Huch, R., Schnelder, H., Rooth, G.

Continuous transcutaneous monitoring of fetal oxygen

tension during labour.

Brit. J.Obstet. Gynaecol. 84(suppl 1):4 (1977).

Huckabee, W.E., Metcalfe, J., Prystowsky, N., Barron, D.H.

Blood flow and oxygen consumption of the pregnant uterus.

Am. J. Physiol. 200:274 (1961).

Itskovitz, J., Goetzman, B.W., Rudolph, A.M.

The mechanism of late deceleration of the heart rate and its relationship to oxygenation in normoxemic and chronicaliy

hypoxemic fetal lambs.

Am. J. Obstet. Gynecol. 142:66 (1982a).

Itskovitz, J., Rudolph, A.M.

Denervation of arterial chemoreceptors and baroreceptors

in fetal lambs in utero.

Am. J. Obstet. Gynecol. 242:H916 (1982b).

Itskovitz, J., La Garma, E.F., Rudolph, A.M.

The effect of reducing umblilical blood flow on fetal

oxygenation.

Am. J. Obstet. Gynecol. 145:813 (1983).

Iwamoto, H.S., Rudolph, A.M., Kell, L.C., Heymann, M.A.

Hemodynamic responses of the sheep fetus to

vasopressin infusion.

Circ. Res. 44:430 (1979). 
James, L.S., Morishtra, H.O., Daniel, S.S., Bowe, E.I.,

Cohen, H., Nleman, W.H.

Mechanisms of late deceleration of the fetal heart rate.

Ari. J. Obstet. Gynecol. 113:578 (1972).

James, L.S., Yeh, M.N., Morishima, H.O., Daniel, S.S.,

Caritis, S.N., Nieman, W.H., Indyk, L.

Umbllical vein occlusion and transient acceleration of the

fetal heart rate. Experimental observations in subhuman primates.

Am. J. Obstet. Gynecol. 126: 276 (1976).

Jansson, I.

133 Xenon clearance in the myometrium of pregnant and

non-pregnant women.

Acta. Obstet. Gynecol. Scand. 48:302 (1969).

Jones, C.T., Robinson, R.O.

Plasma catecholamines in foetal and adult sheep.

J. Physiol. 248:15 (1975).

Jones, C.J.

Autonomic nerves and the control of blood flow.

in: Blood flow, Theory and practice.

Ed. Taylor, D.E.M., Stevens, A.L.

Academic Press, London (1983).

Jongsma, H.W., Evers, J.L.H., Hu1keshoven, F.J.M., de Haan, J.,

Martin, C.B.

Compliance and flow resistance of the umbilical circulation

in vivo in sheep and effects on circulatory parameters.

Soclety for Gymecologic Investigation. Abstract no 45

San Diego (1979).

Joupplla, P., Kırkinen, P., \& EIk-Nes, S.

Acute effect of matermal smoking on the human fetal blood

flow.

Brit. J. Obstet. Gynaecol. 90:7 (1983).

Kety, S.S., Schmidt, C.F.

The nitrous oxide method for the quantitative detemination of cerebral flow in man: Theory, procedure and normal values. 
J. of Clin. Invest. 27:476 (1948).

Kirschbaum, T.H., Lucas, W.E., De Hawen, J.C. \& Assal1, N.S.

The dynamics of placental oxygen transfer.

Am. J. Obstet. Gynecol. 98:429 (1967).

Kunzel, W., Mann, L.I., Bhakthavathsalan, A., Ayromloo1, J.

IL, M.

The effect of umblical veln occlusion on fetal oxygenation,

cardlovascular parameters, and fetal electroencephalogram.

Am. J. Obstet. Gynecol. 128:201 (1977).

Künzel, W., Mann, I.I., Bhakthavathsalan, A., Ayromloo1, J.

Cardiovascular metabolic and fetal brain function

observation following total cord occlusion.

J. Perinat. Med. 8:73 (1980).

Küzel, W., Kastendieck, E., Hohmann, M.

Heart rate and blood pressure response and metabolic

changes in the sheep fetus following reduction of uterine blood flow.

Gynecol. Obstet. Invest. 15:300 (1983).

Ladner, C., Brinkman, C.R. III, Weston, P., Assal1, N.S.

Dynamics of uterine circulation in pregnant and nonpregnant sheep.

Am. J. Phys101. 218:257 (1970).

Lands, A.M., Arnold, A., McAuliff, J.P., Luduena, F.P.,

Brown, T.G.

Differentiation of receptor systems activated by

sympathomimetic amines.

Nature 214:597 (1967).

Lewis, P., Boylan, P.

Fetal breathing: A review.

Am. J. Obstet. Gynecol. 134:587 (1979).

Llanos, A.J., Green, J.R., Creasy, R.K., Rudolph, A.M.

Increased heart rate response to parasympathetic and

beta-adrenergic blockade in growth-retarded fetal lambs.

Am. J. Obstet. Gynecol. 136:808 (1980). 
Makowskl, E.L., Meschla, G., Droegemuller, W., Battaglia, F.C. Distribution of uterine blood flow in the pregnant sheep. Am. J. Obstet. Gymecal. 101:409 (1968). Maloney, J.E., Adamson, T.M., Brodecky, W., Granage, S., Lambert, T.F"., Ritchie, B.E. Diaphragmatic activity and lung liquid flow in the unanesthetlzed retal sheep. J. Appl. Physiol. 39:423 (1975).

Marsal, $K$.

Fetal breathing movements:

Characteristics and clinical significance. Obstet. Gynecol. 52:394 (1978).

Martin, C.B., Murata, Y., Petrie, R.H., Parer, J.T.

Resplratory movements in fetal Rhesus monkeys.

Am. J. Obstet. Gynecol. 119:939 (1974).

Martin, C.B., Gingerlch, B.H.

Factors affecting the fetal heart rate:

genesis of fetal heart rate patterns.

J. Obstet. Gynecol. Nursing. 5:30s (1976).

Martin, C.B.

Regulation of the fetal heart rate and genesis of FHR patterns.

Sem. Perinat. 2:131 (1978).

Martin, C.B., de Haan, J., van der Wildt, B., Jongsma, H.W., Dieleman, A., Arts, T.H.M.

Mechanlsms of late decelerations in the fetal heart rate. A study with autonomic blocking agents in fetal lambs. Eur. J. Obstet. Gynecol. reprod. Blol. 9:361 (1979). Mendez-Bauer, C., Poselro, J.J., Árellano-Hernández, G., Zambrana, M.A., Caldeyro-Barcla, R.

Effects of atropin on the heart rate of the humarn fetus durting labor.

Am. J. Obstet. Gynecol. 85:1033 (1963). Merlet, C., Hoerter, J., Devilleneuve, C., Tchobroutsky, C. Mise en évidence du mouvements resplratolres chez le foetus d'agmeau in utero au cours du dermier mols de la 
gestation.

C.R. Acad. Scl. (Paris) 270:2462 (1970).

Meschia, G., Cotter, J.R., Makowsk1, E.L. Barron, D.H.

Simultaneous measurement of uterine and umblilcal blood

flows and oxygen uptakes.

Quarterly J. of Experimental Physiol. $52: 1$ (1966).

Meyers, R.E., Mueller-Heubach, E., Adamsons, K.

Predictabli1ty of the state of fetal axygenation from

a quantitative analysis of the components of late deceleration.

Am. J. Obstet. Gynecol. 115:1089 (1973).

Mililez, J.M., Morishima, H.O., Stark, R.I., Gutsche, B.B.

Morl, T., Danlel, S.S., James, L.s.

Exfects of terbutaline on the fetal lamb during matemal

oxytocin-induced uterine contractions.

J. Perinat. Med, 9:124 (1981).

Muelier-Heubach, E., Battell1, A.F.

Varlabie heart rate decelerations and transcutaneous

$\mathrm{pO}_{2}$ during umblilical cord oclustion in fetal monkeys.

Am. J. Obstet. Gynecol. $144: 796$ (1982).

de Muylder, X., Fouron, J.C., Bard, H., Urfer, F.N.

Changes in the systollo time intervals of the fetal

heart rate after surgical manipulation of the fetus.

Am. J. Obstet. Gynecol. 147:285 (1983).

Naaktgeborer, C., Stegeman, J.H.J.

Untersuchungen uber den Funfluss des Uterus und der

Placenta auf das fetale Wachstum und das Geburtsgewloht,

mit besonderer Berulicks lcktigung des Schares.

Z. THerzucht. Zucht.-B101. 85:245 (1969).

N1Jhuls, J.G., Precht1, H.F.R., Martin, C.B., Bots, R.S.G.M.

Are there behavorlal states in the human fetus?

Early Human Development 6:177 (1982).

Nory, M.J., Plasecki, G., Jackson, B.T.

Effect of prostaglandins $E_{2}$ and $F_{2}$ alpha on unblilcal blood

flow and fetral hemodynamics. 
Prostaglandins 5:543 (1974).

Nuwayh1d, B., Brinkman, C.R. III, Su, C., Bevan, J.A.,

Assal1, N.S.

Development of autonomic control of fetal circulation.

Am. J. Phys101. 228(2):337 (1975a).

Muwaghld, B., BrInkman, C.R. III, Su, C., Bevan, J.A.

Assal1, N.S.

Systemic and pulmonary hemodynamic responses to

adrenergic and cholinergic agonists during

fetal development.

B1ol. Neonate 26:301 (1975b).

Nuwayh1d, B., Cabalum, T., Zugaib., Brinkman, C.R. III.

Comparison of hemodynamic effects of isoxsuprine and

terbutaline in pregnant and nonpregnant sheep.

Soc. Gynecol. Invest.: Abstract 50 (1978).

Nuwayh1d, B., Cabalum, T., Lieb, S.M., Zugaib, M.,

Brinkman, C.R. III, Tabsh, K., Assal1, N.S.

Hemodynamic effects of isoxsuprine and terbutaline in

pregnant and nonpregnant sheep.

Am. J. Obstet. Gynecol. 137:25 (1980).

Dakes, G.K., Walker, A.M., Ehrenkrenz, R.A., Cefalo, R.C.,

Chez, R.A.

Uteroplacental blood flow during hyperthermia with and without repiratory alkalosis.

J. Appl. Physiol. 41:197 (1976a).

Oakes, G.K., Walker, A.M., Ehrenkranz, R.A., Chez, R.A. Effect of propranolol infusion on the umbilical and uterine clrculations of pregnant sheep. Arn. J. Obstet. Gynecol. 126:1038 (1976b).

Parer, J.T.

The effect of contractions and hypoxia on fetal oxysen consumption in the chronically instrumented sheep.

In: Proceedings VIII World Congress of Gynecology and Obstetrics, Mex1co City, Aostract 156, pag. 77 
Ed. Excerpta Medica, Ansterdam (1976).

Parer, J.T.

Effect of atropin on heart rate and oxygen consumption

of the hypoxic fetus.

Gynecol. Invest. 8:50 (1977).

Parer, J.T., Krueger, T.R., Harris, J.L.

Fetal oxygen consumption and mechanisms of heart rate

response during artificially produced late decelerations

of fetal heart rate In sheep.

Am. J. Obstet. Gynecol. 136:478 (1980).

Parer, J.T.

The influence of beta-adrenergic activity on fetal heart rate and the umbllical circulation during hypoxia in retal sheep.

Am. J. Obstet. Gynecol. 147:592 (1983).

Pearson, A.N., Sauter, R.W.

The innervation of the umbllical vein in humen embryos

and fetuses.

Am. J. Anat. 125:345 (1969).

Peeters, L.L.H.

Fetal blood flow at various levels of oxygen.

A study in a chronic sheep preparation with radioactive

microspheres.

Thesis, Catholic University NiJmegen,

The Netherlands (1978).

Pohlman, A.G.

The fetal circulation through the heart.

Bull Johns Hopkins Hosp. 18:409 (1907).

Pohliman, A.G.

The course of the blood through the heart of the

fetal mammal, with a note on the reptilian and

amphibian c1rculations.

Anat. Rec. 3:75 (1909).

Poore, E.R., Walker, D.W.

Chest wall movements during fetal breathing in the sheep.

J. physiol. 301:307 (1980). 
Power, G.G., Longo, L.D.

Sluice Mow in placenta: matemal vascular pressure effects on fetal circulation.

Am. J. Phys10l. 225/6:1490 (1973).

Power, G.G., Longo, I.D.

Fetal circulation times and their implications for

t1save oxygenation.

Gynecol. Invest. 6:342 (1975).

Power, G.G., Gilbert, R.C.

Umbilical vascular compliance in sheep.

Am. J. Phys1ol. 233:H660 (1977).

Rankin, J.H.G., Phemetton, T.M.

Eff'ect of norepinephrine on the ovine umbilical

elrculation.

Proc. Soc. Exp. B1o1. Med. 152:312 (1976).

Rankin, J.H.G., Phemetton, T.M.

Alpha and anglotensin receptor tone in the

near-term sheep fetus.

Proc. Soc. Exp. B1ol. Med. 158:166 (1978).

RankIn, J.H.G., McLaughlin, M.K.

The regulation of the placental blood flows.

J. Develop. Phys1ol. 1:3 (1979).

Rankin, J.H.G., Stock, M.K., Anderson, D.F.

Fetall heart rate and umbllical blood flow.

J. Develop. Physiol. 2:11 (1980).

Reneman, R.S., Schnelder, H., Wleberdink, J.,

Brouwer, F.A.S.

Electromagnetische stroomsterkteneting van het bloed.

Ned. TH.jd. Geneeskd.. 114:1090 (1970).

Reuss, M.L., Rudolph, A.M.

Distribution and recirculation of umbilical and

systemic venous blood flow in fetal lambs

during hypoxia.

J. Develop. Phys1ol. 2:71 (1980). 
Reuss, M.L., Rudolph, A.M., Heymanm, M.A.

Selective distribution of microspheres injected into

the umbillaal velns and inferior venae cavae of fetal sheep.

Am. J. Obstet. Gynecol. 141:427 (1981).

Reuss, M.L., Rudolph, A.M., Heymann, M.A.

Phasic blood flow pattems in the supertor and infertor

venae cavae and umblilical vetin of fetal sheep.

Am. J. Obstet. Gynecol. 145:70 (1983).

Robson, J.M., Schild, H.O.

Effect of drugs on the blood rlow and activity of the uterus.

J. Physiol. $92: 9$ (1938).

Rosenfeld, C.R., Mormis, F.H., Battaglia, F.C., Makowski, E.I.,

Meschia, $G$.

Effect of estradiol 17 beta on blood fllow to reproductive

and non-reproductive tissues in pregnant ewes.

An. J. Obstet. Gynecol. 124:619 (1975).

Rosenfeld, C.R., Barton, M.D., Meschla, G.

Effect of epinephrine on distribution of blood flow

in the pregnant ewe.

Am. J. Obstet. Gymecol. 124:156 (1976).

Rudolph, A.M., Heymann, M.A.

The clrculation of the fetus in utero. Methods for studying

distribution of blood Plow, cardiac output, and organ blood

flow.

Circ. Res. 21:163 (1967).

Rudolph, A.M., Heymann, M.A.

Circulatory changes during growth of the fetal lamb.

Circ. Res. 26:289 (1970).

Fudolph, A.M.

Factors affecting umblilcal blood flow in the lamb

in utero.

In: Perinatal Mediclne, pag. 159-172

Ed: G. Rooth, L.E. Matteby

Almgrist and W1kse11 Int., Stockholm (1976).

Rudolph, A.M., Heymann, M.A.

Methods for studying the circulation of the fetus lin utero. 
In: Animals models in fetal medicine (1) pag. 1-57,

Ed. P.W. Nathanielsz.

El.sevier/North Holland Blomedical Press (1980). Rurak, D.W., Gruber, N.C.

Increased oxygen consumption assoclated with breathing activity in fetal lambs.

J. Appl. Phys1ol.: Respirat. Environ. Exercise Phys1ol. 54(3):701 (1983).

Saling, E.

Neues Vorgehen zur Untersuchung des Kindes unter der Geburt. Arch. Gynakkol. 197:108 (1962).

Senges, J., Mizutani, T., Pelzer, D., Brachmann, J., Sonnhof, U., ktabler, $W$.

Effect of hypoxia on the sinoatrial node, atrium and atrioventricular node in the rabbit heart.

Cire. Res. 44:856 (1979).

Shlnebourne, E.A., Vapaavour1, E.K., Willians, R.L.,

Heymann, M.A., Rudolph, A.M.

The development of baroreflex activity in unanesthetized

fetal and neonatal lambs.

C1rc. Res.31:710 (1972).

Shnider, S.M., Wright, R.G., Levinson, G., Rolzen, M.F.,

Wall1s, K.L., Rolbin, S.H., Craft, J.B.

Uterine blood fllow and plasma norepinephrine changes

during matemal stress in the pregnant ewe.

Anestheslology 50:524 (1979).

Slassi, B., Wh, P.Y.K., Blanco, C., Martin, C.B.

Baroreceptor and chemoreceptor responses to umblilcal

cond occlusions in fetal lambs.

B1o1. Neonate. 35:66 (1979).

Soma, L.R., Whtte, R.J., Kane, P.B.

Surgical preparation of a chronic matemal fetal model In pregnant sheep: A technique for the measurement of mlddle uterine blood flow, umbllical blood flow, and fetal sampling in the awake sheep. 
J. Surg1cal Res. 11:85 (1971).

Tabsh, K., Nuwayhid, B., Erkkola, R., Zugatb, M., Lieb, S.,

Ushloda, E., Brinkman, C.R. III, Assal1, N.S.

Hemodynamic responses of the pelvic vascular bed to

vasoactive stimuli in pregnant sheep.

Biol. Neonate. 39:52 (1981).

Thormburg, K.L., Bissonnette, J.M., Faber, J.J.

Absence of fetal placental waterfall phenomenon in

chronically prepared fetal lambs.

Am. J. Physiol. 230/4:886 (1976).

Towell, M.E., Lysak, I.

Mild umbilical cord compression and arterial blood gases in

the fetal lamb.

In: Fetal and newborm cardiovascular physiology.

Vol. 2. Fetal and newborm circulation, pas. 289-300

Ed. Longo, L.D., Reneau D.D., Garland STPM Press,

New York (1978).

Vapaavour1, E.K., Shinebourne, E.A., Wll11ams, R.L.,

Heymann, M.A., Rudolph, A.M.

Development of cardiovascular responses to autonomic

blockade in intact fetal and neonate lambs.

Biol. Neonate. 22:177 (1973).

Vesalius, A.

Examen observationum Fallopp11.

Venetils,

Apud Franciscum de Francisc1s, Senensem (1564).

Westersten, A., Rlce, E., Brinkman, C.R. III, Assall, N.S.

A balanced field-type electronagnetic flowmeter.

J. Appl. Phys101. 26:497 (1969).

Wheeler, T., Gennser, G., Lindvall, R., Murrils, A.J.

Changes in the fetal heart rate associated with

fetal breathing and fetal movements.

Brit. J. Obstet. Gynaecol. 87:1068 (1980). 
WLIds, P.L.

Observations of uterine fetal breathing movements-A review.

Am. J. Obstet. Gynecol. $131: 315$ (1978).

wan der WLIdt, $B$.

Heart rate, breathing movenents and brain activity

in fetal lambs.

Thes1s, Catholic University Nijmegen,

The Netherlands (1982).

W1.Ikening, R.B., Anderson, S., Martensson, L., Meschia, G.

Placental transfer as a function of uterine blood flow.

Ain. J. Physlol. 242:H429 (1982).

Winslow, 1781 (cited by wilds 1978).

Wyatt, D.G.

Blood flow and blood flow velocity measurement in vivo

by electromagnetic induction.

Trans. Inst. MC 4:61 (1982).

Zink, J., Van Petten, G.R.

Noradrenergic control of blood vessels in the

prennature lamb retus.

B1ol. Neonate. 39:61 (1981).

Zuntz, N.

Ueber die Respiration des Săugethier Fötus.

Pflutg Arch. Ges. Phystol. 14:605 (1877).

Zwelfel, $\mathbb{P}$.

Die Resplration des Fotus.

Arch. Gynaek. 9:291 (1876). 
CURRICULUM VITAE

$27-05-1953$

1971

1971

$1974-1975$

1978

1978

1983

1983
Geboren te Brunssum

Eindexamen Gymnasium beta aan het R.K. Gymnasium Rolduc te Kerkrade

Aanvang studie geneeskunde aan de Gemeentelijke Universiteit van Amsterdarn

Kandidaatassistentschap in het laboratorium voor Fyslologie, Jan Swammerdam Instituut te Amsterdam

Artsexamen aan de Gemeentel1 jke Universiteit van Aunsterdam

Aanvang oplelding tot gymaecoloos in het Strit Annadal Zlekenhuis te Maastricht (ople1der Frof. Dr. J. de Haan)

Inschrijuing specialistenregister

Verbonden als gynaecoloog aan de afdeling obstetrie en gynaecologie van het Sint Annadal Ziekenhuis te Maastricht 